UNIVERSIDADE DE SÃO PAULO

ESCOLA DE COMUNICAÇÕES E ARTES

ELVINA MARIA CAETANO PEREIRA

\title{
Tecido de vozes: texturas polifônicas na cena contemporânea mineira
}

São Paulo 2011 


\section{Tecido de Vozes: texturas polifônicas na cena contemporânea mineira}

Tese apresentada ao Departamento de Artes Cênicas da Escola de Comunicações e Artes da Universidade de São Paulo para obtenção do título de Doutora em Artes Cênicas

Área de Concentração: Teoria e Prática do Teatro Orientadora: Prof. Dra. Sílvia Fernandes da Silva Telesi

São Paulo 
Autorizo a reprodução e divulgação total ou parcial deste trabalho, por qualquer meio convencional ou eletrônico, para fins de estudo ou pesquisa, desde que citada a fonte.

Catalogação na publicação

Serviço de Biblioteca e Documentação

Escola de Comunicações e Artes da Universidade de São Paulo

PEREIRA, Elvina Maria Caetano

Tecido de vozes: texturas polifônicas na cena contemporânea mineira/Elvina Maria Caetano Pereira - São Paulo: E.M.C. Pereira, 2011

267 p.: il.

Tese (Doutorado) - Escola de Comunicações e Artes/ Universidade de São Paulo.

Orientadora: Prof ${ }^{\mathrm{a}}$ Drª Sílvia Fernandes da Silva Telesi

Bibliografia

1 Dramaturgia processual. 2. Processo Colaborativo.

3. Polifonia. 4. Autoria. 5. Coletivos teatrais. 6. Cena Contemporânea. 7. Escritura. 8. Performatividade.

I. Título II. Telesi, Sílvia Fernandes da Silva.

CDD 21. ed. - 8o8.2 


\section{FOLHA DE APROVAÇÃO}

Elvina Maria Caetano Pereira

Tecido de vozes:

texturas polifônicas na cena contemporânea mineira

Tese apresentada ao Departamento de Artes Cênicas da Escola de Comunicações e Artes da Universidade de São Paulo para obtenção do título de Doutora em Artes Cênicas Área de Concentração: Teoria e Prática do Teatro

Aprovada em:

\section{Banca Examinadora}

Prof. Dra. Sílvia Fernandes da Silva Telesi (Orientadora).

Instituição: ECA/USP

Assinatura:

Prof. Dr.

Instituição:

Assinatura:

Prof. Dr.

Instituição:

Assinatura:

Prof. Dr.

Instituição:

Assinatura:

Prof. Dr.

Instituição:

Assinatura: 
Ao Thomás. A melhor obra. 


\section{AGRADECIMENTOS}

Ao meu filho Thomás Ravy, por seu companheirismo e paciência infinitos.

À Ana Maria Caetano, minha irmã e amiga, e a Roque, pelo apoio incondicional.

À Lissandra Guimarães, minha amiga-irmã, companheira de jornada, pela mão estendida na hora de saltar no abismo.

Ao Davi Pantuzza, meu amor e incentivador, pela leitura atenta de minha escrita.

À Tereza Castro, amiga quase mãe, pela ajuda precisa nas horas difíceis.

Aos amigos Miguel Vicentim e Cris Rangel, pela amizade e apoio imprescindível.

Ao Clóvis Domingos, pelas valiosas interlocução e indicações bibliográficas.

Aos amigos Marcelo Rocco, Matheus Silva e Marcos Alexandre, pelo empréstimo de importante parte da bibliografia.

Ao Saulo Salomão, Erica Vilhena, Joyce Malta, William Neimar, Moacir Prudêncio, Idelino Júnior, Mariana Bernardes, Didi Vilela, Patrícia Sene, João Alberto Azevedo, Fernando Sette, eternos obscênicos, por suas provocações e diálogos na criação. Ao Admarzinho Fernandes, por tudo.

Às companheiras da Marcha Mundial das Mulheres, em especial à Hozana Passos, pelas trocas pessoais e ações políticas compartilhadas.

Aos integrantes do projeto Cena $3 \times 4$, em especial aos artistas da Maldita Cia., do Grupo Teatro Invertido e da Cia. Luna Lunera, pelos materiais cedidos.

Ao Daniel Protzner, pela cessão generosa de fotos que ilustram esta tese.

Ao Paulo Pimenta Marques, pela tradução do resumo.

Aos professores Fernando Mencarelli, da UFMG, e Antônio Araújo, da USP, pela análise rigorosa e conselhos mais do que úteis, no Exame de Qualificação.

Ao professor José Eduardo Vendramini, pelo acolhimento ao meu projeto.

À Andreia Zaik, funcionária do PPGAC, por todo auxílio e gentileza.

À Ivete Mello, chefe do Serviço de Pós-Graduação, por toda presteza.

À Suzana Almeida, da PROPP/UFOP, por seu auxílio na garantia da bolsa.

À CAPES, pelo importante apoio financeiro.

E, por fim, à minha orientadora querida, Sílvia Fernandes, por sua acolhida mais que generosa e por sua leitura mais que rigorosa, por todo o carinho e confiança. 


\section{RESUMO}

PEREIRA, Elvina M.C. Tecido de Vozes: Texturas Polifônicas na Cena Contemporânea Mineira. 2011. 267 f Tese (Doutorado) - Escola de Comunicações e Artes, Universidade de São Paulo, São Paulo, 2011.

A tese investiga as texturas teatrais produzidas no âmbito dos processos de criação colaborativa vivenciados por coletivos teatrais de Belo Horizonte, a partir de sua experiência de participação dentro do projeto Cena $3 \times 4$. O projeto, realizado de 2003 a 2005, pela Maldita Cia. em parceria com o Galpão Cine Horto, propunha a criação concomitante de quatro espetáculos teatrais por meio da pesquisa dos princípios colaborativos e do diálogo não somente criativo, mas também metodológico ocorrido entre os núcleos de criação compostos por grupos teatrais da cidade e por diretores e dramaturgos orientados por Antônio Araújo e Luiz Alberto de Abreu.

A principal questão da tese concerne às possibilidades de texturas teatrais polifônicas que podem ser tecidas, tanto no plano enunciativo como no plano ficcional, em um processo de criação colaborativa. Ou seja, na medida em que o processo colaborativo garante aos criadores da cena um espaço de proposição eqüipolente, a partir de suas funções artísticas específicas, e privilegia o embate entre as matérias cênicas heterogêneas, ele - como um sistema de criação polifônico - resultaria, necessariamente, em uma dramaturgia também polifônica, cuja articulação textual tornaria visível tanto as marcas processuais quanto os rastros das "vozes" presentes na criação? Visando responder essas questões, examino o conceito de dramaturgia e texto, bem como as relações entre texto e cena no âmbito do pensamento teatral do século XX e da contemporaneidade e, por meio dos princípios colaborativos e das noções de polifonia, escritura e performatividade, analiso as relações entre os processos de criação investigados e as suas resultantes textuais.

PALAVRAS-CHAVE: Dramaturgia processual. Processo colaborativo. Polifonia. Autoria. Coletivos teatrais. Cena Contemporânea. Escritura. Performatividade. 


\begin{abstract}
PEREIRA, Elvina M.C. Tissue of voices: polyphonic textures on the contemporary scene in Minas Gerais. 2011. 267 p Thesis (Doctorate) - Escola de Comunicações e Artes, Universidade de São Paulo, São Paulo, 2011.
\end{abstract}

The thesis investigates the theatrical textures produced within the scope of the collaborative creation processes lived by theatrical collectives from Belo Horizonte, taking into account their active experience in the Cena $3 \times 4$ project. The project carried out by Maldita Cia from 2003 to 2005, together with Galpão Cine Horto, proposed the simultaneous creation of four stage shows through the research of collaborative principles and a, not only creative, but also methodological, dialogue which took place between the creation teams, composed by theatrical groups of the town, and by directors and playwrights managed by Antônio Araújo and Luiz Alberto de Abreu.

The main question of the thesis concerns the possibilities of polyphonic theatrical textures that can be woven, either on the enunciative level or the functional level, within a process of collaborative creation. In other words, as far as the collaborative process assures the scene creators some space from a equipollent proposition, considering their specific artistic functions, and favors the clash between the heterogeneous scenic subjects, would it - as a system of polyphonic creation necessarily result in a polyphonic dramaturgy, too, whose textual connection would make both the processual marks and the traces of the "voices" present in the creation visible? Aiming at answering these questions, I examine the concept of dramaturgy and text, as well as the relations between text and scene in the scope of the $20^{\text {th }}$ century and contemporaneity theatrical thought; and, by means of the collaborative principles and the notions of polyphony, scripture and performativity, I analyze the relations between the creation processes investigated and their textual outcomes.

Key words: Processual dramaturgy. Collaborative process. Polyphony. Authorship. Theatrical collectives. Contemporary Scene. Scripture. Performativity. 


\section{LISTA DE ILUSTRAÇÕES}

FIG. o1: Atriz Lissandra Guimarães em cena de Casa das Misericórdias........................ 75

FIG. 02: Ator Lenine Martins em cena de Casa das Misericórdias................................ 95

FIG. 03: Atriz Lissandra Guimarães em cena de Casa das Misericórdias...................... 96

FIG. 04: Ator Lenine Martins em cena de Cara Preta.................................................. 107

FIG. 05: Atores Rita Maia e Leonardo Lessa em cena de Olhar Cativo......................... 117

FIG. o6: Atriz Rita Maia em cena de Medeiazonamorta .............................................. 132

FIG. o7: Ator Camilo Lélis em cena de Proibido Retornar............................................ 143

FIG. o8: Marcas de corpos e escritas de Nina Caetano, durante a intervenção urbana

Mulheres Mortas. 169

FIG. o9: Tapete de revistas femininas e escritas de Nina Caetano, durante a intervenção urbana Baby Dolls, uma exposição de bonecas.

172

FIG. 10: Atriz Lissandra Guimarães com sua mulher-corpo-objetos, durante a intervenção urbana Mulheres Mortas. 182

FIG. 11: Escrita de Nina Caetano e as atrizes Joyce Malta e Lissandra Guimarães, durante a intervenção urbana Baby Dolls, uma exposição de bonecas. 192 FIG. 12: Escrita de Nina Caetano e a atriz Erica Vilhena, durante a intervenção urbana Baby Dolls, uma exposição de bonecas. 


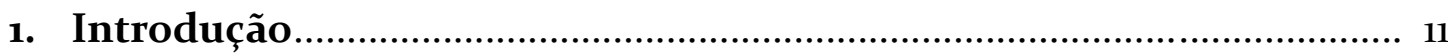

2. Dramaturgia colaborativa e Textualidades Contemporâneas

2.1. Dramaturgia(s) e o drama.............................................................. 16

2.2. Dramaturgia épica, dramaturgia rapsódica................................. 25

2.3. Texturas da cena............................................................................ 35

2.4. Dramaturgia coletiva, autoria compartilhada............................... 41

2.5. Dramaturgias polifônicas, poéticas do espaço.............................. 61

3. Maldita Companhia: em busca de uma dramaturgia polifônica

3.1. A gênese: projeto Cena 3x4............................................................ 66

3.2. A dramaturgia rapsódica de Casa das Misericórdias................... 72

3.3. Solo polifônico, textura pós-dramática em Cara Preta............... 101

4. Desdobramentos colaborativos do projeto Cena 3x4. Estudo de caso: Grupo Teatro Invertido

4.1. Teatro de grupo: do grupo de pesquisa ao teatro de pesquisa

4.2. A experiência no projeto Cena 3x4: olhares sobre a cena.......... 117

4.3. Em busca de uma dramaturgia pós-dramática.............................. 126

4.4. Por uma dramaturgia autoral............................................................ 134

5. A rede colaborativa obscênica: dramaturgias no corpo da cidade

5.1. Coletivos e redes de colaboração.................................................... 151

5.2. Poéticas obscênicas............................................................................. 157

5.3. Performando a dramaturgia ou Uma escrita

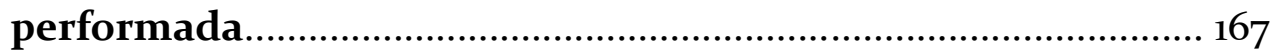

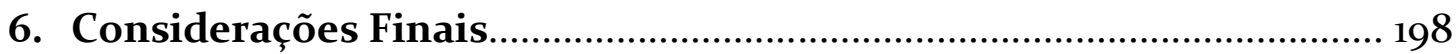

REFERÊNCIAS BIBLIOGRÁFICAS......................................................... 203

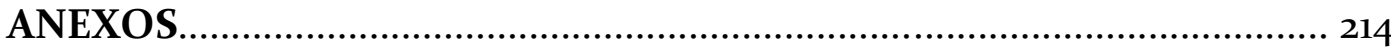


É no momento em que cada mão (diferente) salta por cima da outra (e não uma depois da outra), que o buraco se produz e arrasta o sujeito do jogo o sujeito do texto. Roland Barthes 


\section{Introdução}

A presente tese tem como objeto de estudo, as texturas teatrais produzidas no âmbito dos processos de criação colaborativa vivenciados por coletivos teatrais de Belo Horizonte, a partir de sua participação no projeto Cena $3 \times 4$. Sua principal questão diz respeito às possibilidades de tessitura de uma dramaturgia polifônica - tanto no plano enunciativo como no plano ficcional - no interior de um sistema de criação teatral que, da perspectiva aqui adotada, é polifônico por excelência, na medida em que privilegia, sobretudo, o embate entre as diversas "vozes" criadoras e suas matérias cênicas heterogêneas. Ou seja, a tese investiga se o processo colaborativo, ao garantir aos criadores da cena um espaço de proposição eqüipolente, a partir de suas funções artísticas específicas, resultaria, necessariamente, em uma textura teatral polifônica, cuja articulação dramatúrgica tornasse visível tanto as marcas processuais quanto os rastros das “vozes” presentes na criação.

O projeto Cena 3X4, realizado de 2003 a 2005, em Belo Horizonte, foi idealizado por um coletivo de artistas independentes que eram oriundos dos núcleos de pesquisa em Dramaturgia e Direção do Galpão Cine Horto, importante centro cultural fundado, em 1998, pelo Grupo Galpão. O coletivo, composto pela atriz Lissandra Guimarães, pelos diretores e atores Amaury Borges e Lenine Martins e por mim, dramaturga, desejava aprofundar a investigação dos princípios de uma criação colaborativa, pesquisa que tínhamos iniciado em 2001, por meio da oficina de processo colaborativo ministrada por Antônio Araújo, diretor do Teatro da Vertigem - importante grupo paulista que utiliza essa dinâmica como metodologia de criação em seus espetáculos e por Luiz Alberto de Abreu, dramaturgo paulista que, juntamente com Araújo, é um dos responsáveis pela disseminação do processo colaborativo em todo o país.

Com a finalidade de possibilitar não somente a experimentação, a partir da montagem de um espetáculo, de uma criação que permitisse a todos os participantes do processo contribuir, efetivamente, para a construção do discurso da cena, mas também de ampliar a experiência por meio do diálogo, em criação, com outros artistas e pesquisadores, o coletivo de artistas concebeu um projeto de pesquisa que funcionasse como um espaço de compartilhamento dos processos de criação de quatro 
núcleos formados, inicialmente, por atores, diretores e dramaturgos. Essa pesquisa culminou não só na criação do projeto Cena $3 \times 4$, como ainda na consolidação do próprio coletivo de artistas que, hoje denominado Maldita Companhia de Investigação Teatral, está com nova formação e em seu segundo espetáculo.

$\mathrm{Na}$ primeira edição do projeto, em 2003, os diretores e dramaturgos eram oriundos das oficinas de Direção e Dramaturgia do Galpão Cine Horto. Para a atuação, foram convidados grupos teatrais da cidade, compostos, em sua maioria, por atores. Eram, naquele primeiro ano, a Maldita e a Cia. Luna Lunera, além dos grupos Trama e Labapi. No segundo ano do projeto (2004), foi agregada, como orientadora pontual ${ }^{1}$ para a atuação, a atriz e diretora Tiche Vianna, do Barracão Teatro, e foram convidados os grupos Reviu a Volta, Teatro Invertido, Acômica e Armatrux, bem como diretores e dramaturgos (ou escritores) atuantes em Belo Horizonte. Na terceira e última edição do Cena 3×4, em 2005, a partir da experiência da Maldita - que, no primeiro ano do projeto, agregara, em seu bojo, diretores, atores, dramaturga, músico e cenógrafa houve a tentativa de incluir, nos processos de criação, outras funções além da tríade básica do processo colaborativo ${ }^{2}$, presente nos dois primeiros anos do projeto.

Pela primeira vez, optou-se pela abertura de um edital, no qual se privilegiava a escolha de núcleos de criação que, a princípio, já viriam "prontos” - ou seja, com a configuração completa, pretendida para o desenvolvimento do trabalho - ao contrário dos anos anteriores, em que os grupos eram convidados e a composição dos núcleos era feita pela coordenação do Cena $3 \times 4$. Nesse ano, participaram os grupos Mais de 30, composto por dramaturgo, diretora, atores, músicos e artistas plásticos; As Medéias, companhia da cidade de Ouro Preto composta por dramaturga, diretora, atores e cenógrafa, além da Cia. das Flores e do Teatro Negro Atitude, com a formação usual do projeto. Foram também estabelecidos quatro grupos de discussão - atuação, direção,

\footnotetext{
${ }^{1}$ Em setembro, Tiche Vianna se juntou ao projeto para ministrar uma oficina para os atores participantes dos núcleos de criação do Cena $3 \times 4$ e, por meio desta, ajudá-los a construir seus instrumentos colaborativos na relação com os outros criadores da cena.

${ }^{2}$ Tendo as práticas colaborativas do Teatro da Vertigem como eixo, o projeto Cena $3 x_{4}$ acabou por adotar, como modelo inicial, a configuração que se apresentava nos processos de criação do grupo, caracterizada por uma "perspectiva tripartida" que trazia "para o centro da criação atores, dramaturgo e diretor", conforme salienta Antônio Araújo em SILVA, Antônio C. de Araújo. A Gênese da Vertigem: o processo de criação de $\boldsymbol{O}$ Paraíso Perdido. Dissertação (Mestrado em Artes Cênicas) - Escola de Comunicação e Artes da USP, 2002, p. 106.
} 
dramaturgia, cenografia - que, orientados pelos integrantes da Maldita, contribuíram para a resolução de questões concernentes à especificidade de cada função artística.

Em suas três edições, o projeto Cena $3 \times 4$ contou, então, com a participação de diversos artistas da cidade, entre diretores, escritores, cenógrafos e grupos teatrais, e alterou, significativamente, seu pensamento teatral e metodologias de criação. Muitos dos grupos teatrais, por exemplo, passaram a adotar o processo colaborativo como metodologia de criação em seus processos de montagem. É o caso da própria Maldita que, além de manter uma prática colaborativa constante, deu origem a outro coletivo que também se pauta, em seu modo de organização e funcionamento, em princípios de criação compartilhada: o Obscena, agrupamento independente de pesquisa cênica. Também são exemplares a Cia. Luna Lunera que, em suas experiências anteriores ao Cena $3 \times 4$, tinha encenado peças teatrais de dramaturgos como Nelson Rodrigues, e o Grupo Teatro Invertido que, após sua experiência de participação no projeto, tem mantido uma prática de pesquisa e criação totalmente orientada pelos princípios do processo colaborativo.

A partir de minha experiência de participação e coordenação do projeto Cena $3 \times 4$ - bem como da observação dos desdobramentos teóricos e práticos que o projeto, posteriormente, teve - interessou-me perceber de que forma se relacionam as diversas vozes criadoras presentes nos processos colaborativos de criação cênica, bem como as possibilidades dramatúrgicas surgidas daí. O estudo das relações entre texto e cena principalmente no que tange à investigação das processualidades dramatúrgicas e cênicas e às metodologias de criação compartilhada - lida, atualmente, com um alargamento conceitual das noções de dramaturgia e encenação, de texto, obra e autoria e com uma ampla diversidade terminológica, expressa no uso - corrente no campo dos estudos teatrais contemporâneos - de acepções como "dramaturgia coletiva", "dramaturgia do ator", "dramaturgia do espectador", "dramaturgia do espaço", "dramaturgia da cena”, "texto cênico" e "escrita cênica”, entre outros. Tal aspecto - pensado em relação à produção dramatúrgica dos coletivos teatrais acompanhados por mim em seus processos de criação, nos últimos anos - levou-me a algumas questões: $\mathrm{O}$ que se denomina texto? A composição de ordem lingüística (ou literária) produzida pelo dramaturgo? O conjunto resultante da criação, concretizada em termos de espetáculo? As falas pronunciadas pelas personagens (quando elas 
existem) ou pelos atores em cena? O que se denomina dramaturgia: o trabalho específico de composição do todo, produzido pelo dramaturgo? Todo processo de composição poética e produção de sentido e significâncias - ainda que individual - que ocorre no interior da criação e é nesse sentido que se usa dramaturgia do ator ou dramaturgia da luz? Que dramaturgia o coletivo produz? Qual a distinção entre autoria e dramaturgia, entre criação e encenação ou entre obra e texto? Quais as distinções entre a encenação e a dramaturgia produzidas no interior dos coletivos teatrais?

Às questões iniciais, agregaram-se outras de igual importância, originadas no avanço de minha investigação dramatúrgica para o campo da intervenção urbana, durante o desenvolvimento do projeto Às margens do feminino: texturas teatrais da beira, junto ao agrupamento Obscena. Essas questões dizem respeito à investigação de uma rede colaborativa de criação e pensamento e às texturas cênicas resultantes de um processo que não deseja a construção de uma obra espetacular, mas de ações performativas no corpo da cidade. Que dramaturgia pode produzir o transeunte, em contato com os fluxos da ação e do cotidiano da cidade? Que texto produz o artista, com seu corpo/escritura?

Visando responder essas questões, tracei dois eixos que funcionaram como orientadores do trabalho de pesquisa. De um lado, a descrição e análise dos processos de pesquisa e criação dos coletivos investigados - tanto em sua experiência no projeto Cena $3 \times 4$, como nas experiências posteriores - foram pensadas como ferramentas para a discussão das relações entre os modos e procedimentos de criação e colaboração utilizados pelos artistas envolvidos no processo e a processualidade dramatúrgica. A definição dos estudos de caso teve como critério a continuidade de uma investigação colaborativa por parte dos coletivos estudados, seja como alteração de seu modo de produção teatral - caso do Grupo Teatro Invertido que, após sua experiência de participação no projeto Cena $3 \times 4$, optou pela tessitura de dramaturgias originais - seja como conceito fundante em sua organização e funcionamento, como é o caso não só da Maldita, mas também do Obscena, os quais tiveram origem no interesse específico pela pesquisa teórica e prática de uma criação compartilhada. Apesar de não ter sido um fator de escolha, considero importante ressaltar, ainda, o vínculo que percebo existir entre uma perspectiva de investigação e aprofundamento de questões ligadas à 
cena contemporânea e o interesse por uma criação compartilhada - no interior da qual o artista tem espaço para desenvolver sua autonomia criativa - pois todos os coletivos teatrais escolhidos têm em comum uma relação direta com os estudos teóricos desenvolvidos nas universidades, sendo, em sua maioria, compostos por pesquisadores da cena teatral que, como professores ou alunos, mantêm um estreito vínculo com os cursos de graduação da UFMG e da UFOP.

Desse modo, tem-se como um dos eixos orientadores da pesquisa os processos propriamente ditos. Por outro lado, interessava-me investigar, além do processo, a obra daí resultante, a fim de perceber quais as características estéticas que o processo imprime à obra. No entanto, mais do que buscar os traços de autoria individualizados ou seja, determinar a quem "pertence" tal elemento da cena inscrito na dramaturgia - a investigação buscou perceber as possibilidades de texturas cênicas produzidas pelas relações colaborativas de criação e, nesse sentido, a tese privilegia a análise das texturas cênicas produzidas nos processos.

Para isso, examino, ao longo dos capítulos que compõem este estudo, o conceito de dramaturgia e texto, bem como as relações entre texto e cena no âmbito do pensamento teatral do século XX e da contemporaneidade - capítulo 1 - além de, por meio da discussão dos princípios da criação colaborativa e do conceito de polifonia, descrever e analisar os processos de criação da Maldita Companhia - capítulo 2 - e do Grupo Teatro Invertido - capítulo 3 - a fim de perceber como se estabelecem as relações entre os procedimentos de criação adotados pelos coletivos teatrais e as inscrições processuais que marcam sua produção textual. Por fim, no capítulo 4, examino o trabalho de pesquisa e criação realizado, em 2008 e 2009, pelo Obscena e, por meio da análise de seus percursos de experimentação cênica - feita à luz das noções de escritura e performatividade - busco perceber como se dá a construção de uma escrita performada durante os fluxos relacionais da ação performativa ocorrida durante a realização da intervenção urbana Baby Dolls, uma exposição de bonecas, fruto das investigações dramatúrgicas que realizei junto às atrizes Lissandra Guimarães, Joyce Malta e Erica Vilhena, no âmbito do projeto Às margens do feminino: texturas teatrais da beira. 


\section{Dramaturgia colaborativa e textualidades contemporâneas}

\subsection{Dramaturgia(s) e o drama}

Abordar o conceito de dramaturgia, nos dias hodiernos, é entrar em terreno minado. Com um largo espectro de uso, o termo, antes restrito à poética do texto teatral - ou, mais especificamente, da obra literária dramática - com o avanço dos estudos sobre o espetáculo e das pesquisas sobre processos de criação e produção dos grupos teatrais, tornou-se terreno mais movediço. No que dizem respeito ao teatro contemporâneo, as acepções de dramaturgia se ampliaram e ocupam, atualmente, um vasto campo, concernente tanto às noções de composição poética quanto de produção de sentido, ocorridas nos diversos níveis da cena. Essa ampliação, evidenciada pela utilização, já bastante corrente, do termo dramaturgias, gera categorias diversas, que vão da criação atoral à recepção teatral, e estreita a relação entre textualidade e materialidade cênica, como é perceptível na afirmação de Fernando Mencarelli .

A dramaturgia entendida como a arte de compor e tecer a materialidade cênica passa a sugerir novas articulações conceituais. Dramaturgia da luz, propõem os artistas da área. Dramaturgia da imagem, ensaiam os estudiosos de um teatro mais imagético e plástico. A percepção das múltiplas textualidades permite vislumbrar a polifonia constitutiva da cena teatral. Dramaturgia da cena, concluem os criadores debruçados sobre a pluralidade sígnica e polissêmica de gestos, sons, palavras, imagens, luz, espaço.

Muitas das categorias geradas por esse alargamento conceitual têm se firmado como campos específicos de estudo, como, por exemplo, as acepções de dramaturgia do espectador - entendida como a produção de sentido gerada pela atividade do

\footnotetext{
${ }^{1}$ MENCARELLI, Fernando Antônio. Dramaturgias em processo: a cena pelo avesso IN: GRUPO TEATRO INVERTIDO. Cena Invertida: Dramaturgias em Processo. Belo Horizonte: Edições CPMT, 2010, pp. 12-25.
} 
espectador em sua relação com a cena ${ }^{2}$ - e de dramaturgia do ator - concernente à composição realizada pelo ator, por meio de sua corporeidade, e que empresta significação ao tecido cênico ${ }^{3}$ - só para lembrar dois termos, bastante usuais dentro das investigações teóricas sobre a cena contemporânea, que são tangenciados nesta tese.

Tendo, portanto, ampliado seu alcance, dramaturgia atualmente se refere tanto à obra do dramaturgo - e, assim, refere-se ao texto literário, mas também à operação realizada por seu autor - quanto ao processo de construção do texto de um espetáculo e ao próprio texto resultante desse processo, e, nesse sentido, confunde-se com as noções de escrita cênica, de texto espetacular e de poética da cena. Como meu interesse diz respeito ao trabalho de composição específico do dramaturgo, ainda que no âmbito dos processos colaborativos de criação cênica, buscarei delimitar, pelo menos inicialmente, as questões concernentes à dramaturgia em um campo mais restrito, o da poética do texto.

Na Poética, obra inaugural do estudo da dramaturgia no ocidente, Aristóteles afirma que sendo a poesia dividida, segundo o seu modo, em épica e dramática, é dramática toda imitação de ações em que os personagens agem e obram diretamente. Embora trate especificamente da forma trágica, para Aristóteles o drama - ou composição dramática - pode ser trágico ou cômico, dependendo do objeto que imita 4 . É preciso notar que, na teoria aristotélica, a palavra drama não está relacionada a uma determinada forma histórica de texto teatral - como é o caso do drama burguês, mais comumente associado ao termo - ainda que algumas formas textuais, de desenvolvimento posterior à Poética, possam corresponder a um "padrão" aristotélico de composição dramatúrgica. Para o filósofo, no entanto, drama vai se referir à noção etimológica de ação e, assim, dramaturgia corresponderia, mais explicitamente, ao

\footnotetext{
${ }^{2}$ Essa atividade do espectador não se dá diante de toda forma de expressão teatral. Segundo Desgranges (2003, 2006, 2008), é precisamente a cena contemporânea (entendida como conectada ao nosso tempo), na qual a dimensão de experiência está presente, que convoca o espectador a produzir significâncias independentes - ou justapostas - daquelas propostas pelo conjunto da encenação.

3 "A emergência dos teatros laboratórios na segunda metade do século 20, associada aos princípios artaudianos que ganharam corpo com as vanguardas teatrais, [...] foi aos poucos afirmando a tessitura das pluralidades constitutivas dos coletivos como uma das principais tarefas criativas. Uma percepção mais clara das múltiplas dimensões da construção do sentido na cena, do gesto à palavra, levava à proposição de uma construção dramatúrgica pensada em diferentes planos [...]. Com os teatros laboratórios afirmava-se a proposição de uma dramaturgia do ator, uma vez que este era convocado a ser elemento propositivo fundante nos trabalhos de criação" (MENCARELLI, 2010: 16-17. Grifos meus).

4 "É também essa diferença o que distingue a tragédia da comédia: esta pinta os homens piores do que são, aquela os torna melhores do que se apresentam na realidade" (ARISTÓTELES, 1992: 1448a).
} 
trabalho de composição das ações humanas. Não sem razão, Aristóteles vai dar uma ênfase especial justamente à poiesis, ao aspecto da composição do texto poético, ou seja, à "sintaxe que organiza os fatos em história e em ficção5”. Para ele, a imitação de ações que é obra do dramaturgo pressupõe certos elementos e parâmetros para sua construção, pois, para manifestar seus efeitos, o drama deve ser a mímesis de uma ação una, completa e de certa extensão, dotada de verossimilhança e causalidade interna.

Apesar de não pretender entrar aqui em questões relativas à oposição entre a visão aristotélica e a visão platônica a respeito do conceito de mímesis, uma vez que tal discussão foge ao escopo deste estudo, considero importante salientar que, ao contrário de Platão - que, abordando a arte de uma perspectiva ética, vai condenar a mímesis dramática - Aristóteles trata a arte poética nela mesma, a partir de suas finalidades e modos de funcionamento. Para ele, o conceito de mímesis - de imitação das ações humanas - traz implícito o processo de ficcionalização próprio da criação literária, pois Aristóteles opõe à poesia - seja ela épica ou dramática - o discurso da história, uma vez que, "o papel do poeta é dizer não o que ocorreu realmente" - esse seria o papel do historiador - "mas o que poderia ter ocorrido na ordem do verossímil ou do necessário "”. Dessa perspectiva, dramaturgia vai se referir mais do que a uma composição da cena no nível de sua materialidade, ao aspecto literário dessa composição, própria do dramaturgo. Aristóteles, mesmo reconhecendo que o espetáculo cênico é a "parte mais emocionante” da tragédia, considera que ele é, também, a parte "menos artística e menos própria da poesia. Na verdade, mesmo sem representação e sem atores, pode a tragédia manifestar seus efeitos ${ }^{8 ”,}$, afirma ele.

A partir de Aristóteles, a teoria vai se debruçar sobre o estudo da dramaturgia como obra literária. Aqui, mais duas considerações: (1). Como salienta Bernard Dort ${ }^{9}$, a teoria, em contraposição à crítica jornalística (que centralizou sua análise no campo efêmero do espetáculo), estudou, durante séculos, o fenômeno do teatro no que ele tinha de mais durável, sólido e eterno: o texto. Por conseqüência, pode-se dizer que a

\footnotetext{
${ }^{5}$ COMPAGNON, Antoine. O demônio da teoria. Belo Horizonte: Editora UFMG, 2001, p. 104.

${ }^{6}$ ARISTÓTELES, 1992: 1451b.

${ }^{7}$ Ibidem.

${ }^{8}$ Ibidem: $145 \mathrm{ob}$ (grifos meus).

${ }^{9}$ DORT, Bernard. Prefácio IN: SARRAZAC, Jean-Pierre. O Futuro do Drama. Porto: Campo das Letras, 2002.
} 
mise-en-scène $e^{10}$ não foi vista, durante muito tempo, como obra, mas como plasmação da peça de teatro, esta sim obra do dramaturgo. Nesse sentido, uma abordagem teórica que fosse problematizada pela tensão existente entre as noções de escrita teatral e dramaturgia da cena, nem seria vista como questão. (2) Aliada a esse pensamento, a divisão rigorosa dos gêneros literários pressupunha um funcionamento distinto para a narrativa épica e a poesia dramática, a fim de garantir que, nesta, o mundo narrado fosse posto em movimento por um mecanismo automovente - sustentado pelas ações do protagonista e por seu encadeamento causal - o mecanismo dramático. Nessa concepção, a autonomia do mundo narrado só é possível com a absoluta separação entre o mundo e o sujeito que o narra, ou seja, no drama, a voz do autor está ausente do mundo plasmado pela construção poética, revelando-se apenas no projeto que o dramaturgo executa, a partir de suas escolhas e decisões estéticas.

Tal visão ganhará força a partir da retomada do ideal clássico pelo Renascimento e, em conseqüência, da retomada dos conceitos aristotélicos (mímesis, causalidade, verossimilhança, unidades de ação, tempo e espaço) que, a partir dos comentadores do filósofo, se elevarão à categoria de paradigmas universais da criação dramatúrgica, independentes de sua condição histórica. A análise aristotélica passa a ser considerada prescrição normativa, ganhando força de lei. E é justamente a partir do Renascimento que a forma histórica que será denominada por drama vai surgir.

Tendo o ser humano como centro, o drama dará vazão a inquietações e conflitos próprios das relações mais horizontais que começam a se estabelecer entre os homens, a partir das transformações históricas ocorridas no período ${ }^{11}$. O conflito já não é da ordem da pólis (ou do transcendente), como na tragédia, nem governado por uma verticalidade própria do divino, como no período imediatamente precedente ao Renascimento, o medieval, mas da ordem do humano. Centrado na relação intersubjetiva, o drama, segundo Szondi ${ }^{12}$, como forma é absoluto e nele quaisquer elementos que escapem à relação entre indivíduos, ou seja, quaisquer aspectos

\footnotetext{
${ }^{10}$ A opção de manter o termo em francês se deve à necessidade de se evidenciar, na palavra encenação, o seu sentido de "colocação em cena", mais amplo do que a noção de escritura cênica, denotada atualmente pelo uso do termo encenação. Nesse sentido, mise-en-scène também pode significar representação.

${ }^{11}$ RAMOS, Luiz Fernando. Pós-dramático ou poética da cena? IN: GUINSBURG, J. \& FERNANDES, S. O Pós-Dramático: um conceito operativo? São Paulo: Perspectiva, 2010, p. 6o.

${ }^{12}$ SZONDI, Peter. Teoria do Drama Moderno. São Paulo: Cosac \& Naify, 2001.
} 
concernentes à interioridade das personagens - líricos - ou às questões de ordem social - épicos - deverão estar ausentes. Caberá, então, às personagens, por meio das relações intersubjetivas - e de sua expressão lingüística, o diálogo - conduzirem a ação dramática. Ainda de acordo com o teórico, a ação deverá ocorrer, necessariamente, no presente: cada ação engendra a próxima (causalidade), pois qualquer descontinuidade temporal ou espacial denunciaria a presença do autor, responsável pela montagem.

Como uma "dialética fechada em si mesma"13", o drama desconhece tudo o que não se refira a ele próprio - por seu caráter absoluto, o drama é primário, só representando a si mesmo - e, em função disso, nem a presença do autor nem a do espectador devem ser percebidas.

O dramaturgo está ausente no drama. [...] As palavras pronunciadas no drama são todas elas de-cisões [Ent-schlüsse]; são pronunciadas a partir da situação e persistem nela; de modo algum devem ser concebidas como provenientes do autor. O drama pertence ao autor só como um todo, e essa relação não é parte essencial do seu caráter de obra. $\mathrm{O}$ mesmo caráter absoluto demonstra o drama em relação ao espectador. Assim como a fala não é expressão do autor, tampouco é uma alocução dirigida ao público. [...] A relação espectador-drama conhece somente a separação e a identidade perfeitas, mas não a invasão do drama pelo espectador ou a interpelação do espectador pelo drama (SZONDI, 2001: 30).

Ou seja, subjacente à noção de drama absoluto está a idéia de que o teatro é, antes de tudo, teatro dramático e, nesse sentido, ele é, em primeira instância, um teatro do texto. Como afirma Sílvia Fernandes, no teatro dramático, a "representação de um cosmos fictício" ocorre em uma caixa preta, "em um palco fechado, ou teológico, como queria Jacques Derrida, e é instaurado por personagens que imitam ações humanas com a intenção de criar uma ilusão de realidade ${ }^{14 ”}$. Segundo Szondi, esse modelo poético do drama vai persistir até o final do século XIX, quando, diante de temáticas novas, próprias do momento histórico em que viviam os dramaturgos, a forma dramática entrará em crise.

\footnotetext{
${ }^{13}$ Ibidem: 30.

14 FERNANDES, Sílvia. Teatros pós-dramáticos IN: GUINSBURG, J. \& FERNANDES, S. O PósDramático: um conceito operativo? São Paulo: Perspectiva, 2010, p. 13.
} 
Na análise empreendida por ele de cinco dramaturgos - Ibsen, Tchékhov, Strindberg, Maeterlinck e Hauptmann - é perceptível a invasão da forma dramática por elementos épicos e líricos. Aspectos considerados como essenciais ao drama como o diálogo, o conflito e a personagem começam a encontrar aí sua dissolução, sendo os componentes da tríade conceitual que o sustenta - ação presente e intersubjetiva substituídos por "conceitos antitéticos correspondentes ${ }^{15}$ ": o presente é substituído pelo passado (Ibsen) ou pela utopia (Tchékhov); a ação pelo estado condicionado (Hauptmann) ou por estados do eu (Strindberg); as relações intersubjetivas são substituídas pela morte (Maeterlinck) ou pelas condições políticas e econômicas (Hauptmann).

Na continuação de sua análise, Szondi afirma que o drama, ainda que passe por tentativas de salvamento, terá, a partir do século $\mathrm{XX}$, sua forma explodida e a precipitação dos novos conteúdos encontrará, a partir de experimentos formais, a consolidação de mudanças estilísticas. Como salienta Sílvia Fernandes, a análise do teórico discorda de uma visão normativa do texto, a qual "leva à suposição de que uma mesma forma dramática pode ser usada em qualquer época, para a construção poética de qualquer assunto ${ }^{16 ”}$. Para ela, Szondi vai, a partir de uma visão dialética, propor "uma equivalência entre forma e conteúdo, com a forma concebida como uma precipitação do conteúdo (como quer Adorno), onde a temática nova funciona como um problema para a antiga moldura formal ${ }^{17 "}$.

Já para Luiz Fernando $\operatorname{Ramos}^{18}$, Szondi vai ignorar, em sua análise da crise que origina o drama moderno, a tensão (e mútua influência) existente entre as formas cênicas - ou "poética do espetáculo"19" - e as formas textuais - ou "poética do dramático 20 " - uma vez que o teórico vai atribuir as transformações operadas na forma dramática somente às relações existentes entre essa mesma forma e os conteúdos que

\footnotetext{
${ }^{15}$ SZONDI, op. cit., p. 91.

${ }^{16}$ FERNANDES, Sílvia. Notas sobre Dramaturgia Contemporânea IN: Teatralidades Contemporâneas. São Paulo: Perspectiva, 2010, p. 154.

${ }^{17}$ Ibidem.

${ }^{18}$ Ele discute (RAMOS, op. cit., pp. 59-7o. Ver nota 10) a validade da noção de pós-dramático - proposta pelo teórico alemão Hans-Thies Lehmann - como conceito operativo para a cena contemporânea. Na esteira, Ramos faz a crítica da abordagem feita pela teoria teatral de tradição marxista, no qual se alinham Szondi e, como seu discípulo direto, Lehmann.

${ }^{19}$ RAMOS, 2010: 60.

${ }^{20}$ Ibidem.
} 
encerra. Para Ramos (2010: 60), ao contrário, essas alterações poderiam ser igualmente atribuídas "à transformação ocorrida no fim do século XIX, a partir da ópera wagneriana, quando o paradigma de uma poética do drama, ou da trama, como tinha sido traçada por Aristóteles, começa a ser substituído pelo de uma poética da cena”. Segundo ele, o paradigma que vai acabar se impondo, ao longo do século XX, é, sobretudo, o da poética do espetáculo, sendo possível pensar toda a tradição moderna - tanto no âmbito da cena como no âmbito do texto - como expressão da "tensão crescente entre uma poética do espetáculo e uma poética do dramático”.

Perspectiva semelhante é defendida por $\mathrm{Heuvel}^{21}$, para quem o teatro moderno bem como o contemporâneo - é marcado por uma reação às convenções literárias do drama, orientada por renovações oriundas da performance. Para Heuvel, o sentido de performance é amplo e abarca desde a noção de encenação de um texto teatral até a visão dela como "uma forma de arte autônoma, como uma alternativa ao drama 'literário’ e, finalmente, como um privilegiado mecanismo de desconstrução do palco teológico e da semiose convencional do drama ${ }^{22 "}$. Segundo ele, é justamente a desconstrução das convenções literárias de sentido, estrutura, enredo, espaço e caracteres, possibilitadas pela performance, que vai alterar substancialmente não só as formas teatrais, como também as próprias formas textuais, que passam a explorar, em sua construção, elementos propriamente performativos.

\footnotetext{
Esses desenvolvimentos e as mudanças estilísticas e conceituais que eles moldaram, na criação de novos tipos de linguagem dramatúrgica - o uso de estruturas narrativas não lineares, o desenvolvimento de modos de representação mais físicos e os experimentos inovadores do tempo, espaço e encenação teatrais - expandiram a capacidade de expressão do teatro ${ }^{23}$.
}

\footnotetext{
${ }^{21}$ HEUVEL, Michael Vanden. Performing Drama/Dramatizing Performance: alternative theater and the dramatic text. Michigan: University of Michigan Press, 1991.

22 '"...] as an autonomous art form, as an alternative to 'literary' drama, and, finally, as the privileged mechanism for deconstructing the theological stage and conventional dramatic semiosis" (HEUVEL, 1991: 5-6. Tradução minha).

${ }_{23}$ "These developments and the stylistic and conceptual changes they have wrought - in the creation of new types of dramatic language, the use of nonlinear narrative structures, the development toward more physical acting styles, and innovative experiments in the use of theatrical time, space, and the mise-enscène - have expanded theater's capacities for expression" (HEUVEL, 1991: 8. Tradução minha).
} 
No que concerne às relações entre a poética do espetáculo e a poética do drama - definido por ele (HEUVEL, 1991: 4) como o campo das convenções lógico-discursivas do texto literário - é especialmente iluminador o capítulo que Heuvel dedica à análise da obra de Beckett, cujas inovações performativas - ocorridas no nível do texto - a aproximam, segundo ele, dos experimentos teatrais da década de 8o, como os de Richard Foreman e de Robert Wilson, e ainda a localizam como um projeto estético à frente do modernismo e precursor do teatro e da dramaturgia contemporâneos.

As peças de Beckett e suas narrativas incisivas revelam as mal definidas perturbações que iniciam o movimento de afastamento da órbita cultural modernista, em direção ao pós-moderno. Além disso, seus últimos trabalhos indicam novas alternativas [...] e mapeiam o que provavelmente vai substituir o que já havia se tornado insípido e chique no pós-modernismo. Ou seja, Beckett é uma figura de transição, cujo projeto estético contraditório atravessa o moderno e o que se segue a ele, ocupando uma posição relativa, tanto atrás dos artistas do teatro contemporâneo (como uma fértil influência modernista sobre eles) como também, de certo modo, antes deles (como um desbravador daquilo que eles estão agora descobrindo). [...] Beckett tanto reflete como gera mudanças significativas na cultura e na consciência contemporâneas ${ }^{24}$

Ao considerar, em contraposição às observações levantadas por Heuvel, o modelo teórico proposto por Szondi - o qual "pressupõe uma forma dramática pura, fechada em si mesma [...], até porque [esta] expressaria as grandes transformações históricas, que inseriram os homens numa relação mais horizontal de troca ${ }^{25}$ - é quase impossível não perceber a pertinência da colocação feita por Luiz Fernando Ramos, ao salientar o estranho silêncio de Szondi no que tange, justamente, às características históricas não só das transformações operadas na cena - naquele que se convencionou chamar de "século da encenação" - mas também as evidentes conseqüências que tais

\footnotetext{
24 "Beckett's plays and narratives acutely disclose the ill-defined perturbations that initiate the movement away from the modernist cultural orbit toward the postmodern. Beyond that, his last works indicate new alternatives [...] and map out what likely will displace that which had already become insipid and chic in postmodernism. That is to say, Beckett is a transitional figure whose contradictory agenda straddles the modern and what follows upon it, occupying a relative position both behind contemporary theater artists (as a brooding modernist influence upon them) and somehow before (as an explorer of what they are currently discovering). [...] Beckett both reflects and engenders significant shifts in contemporary culture and consciousness" (HEUVEL, 1991: 68-69. Tradução e grifos meus).

${ }^{25}$ RAMOS, op. cit., p. 60.
} 
transformações teriam tido, como ressaltado por ele, sobre a escrita teatral do século XX (RAMOS, 2010: 61). Contudo, a visada teórica de Szondi é justificada pelo fato de que sua perspectiva analítica, embora de natureza histórica e não normativa, é pautada na dialética marxista, fundamental para a gênese da categoria de drama moderno que é eixo central do seu trabalho, o drama épico.

Do ponto de vista dialético, torna-se evidente a opção do teórico em discutir essa gênese dentro de uma linha evolutiva de desenvolvimento histórico do paradigma dramático, a partir da tensão entre a forma e o conteúdo textual. A partir dessa perspectiva, é possível considerar que Szondi vai reconhecer, inclusive, o processo de transformação ocorrido nas formas artísticas como um todo (Stendhal e, para não se restringir ao campo literário, Cézanne e Wagner), durante o que ele denomina "período de transição", ou seja, a passagem do século XIX para o século XX. Mesmo que, no campo da encenação, ele acabe por abordar, somente, aquele diretor de teatro que, de alguma forma, "pavimenta” o caminho até Brecht: Erwin Piscator. Como salientado por Szondi, essa "única inserção de acontecimentos da história do teatro 26 " se justifica pela influência que o encenador vai exercer sobre os dramaturgos das décadas seguintes.

Pois a sentença da temática social contra a forma dramática, contida já em Os tecelões, é executada nos anos 20 não primeiramente no domínio da criação dramática, mas no âmbito efêmero da encenação. É o que acontece na obra de Erwin Piscator, cujo livro O teatro político (1929), muito informativo tanto do ponto de vista documental como do programático, apresenta alguns dados que entram no contexto de nosso estudo (SZONDI, 2001: 127).

Para Szondi (2001: 130), a formulação mínima que Piscator utilizava em suas tentativas de encenação - "a elevação do elemento cênico ao histórico, ou, em sua acepção formal, a relativização da cena atual em função do elemento não-atualizado da objetividade" - vai permitir o desenvolvimento, a partir da destruição da "natureza absoluta da forma dramática”, do teatro épico.

\footnotetext{
${ }^{26}$ SZONDI, op. cit., p. 127.
} 


\subsection{Dramaturgia épica, dramaturgia rapsódica}

Divisor de águas, Brecht é também central no modelo analítico proposto por Sarrazac em O Futuro do Drama. Neste, o autor vai se debruçar sobre a produção dramatúrgica contemporânea (principalmente a francesa, com especial foco na obra de Michel Vinaver) a partir da noção de autor rapsodo. Já nos verbetes de dicionário que compõem a epígrafe de seu livro, Sarrazac nos dá uma pista de sua perspectiva teórica:

\footnotetext{
Rhapsodage - Action de rhapsoder, de mal raccommoder.

Rhapsode - Terme d'antiquité grecque. Nom donné à ceux qui allaient de ville en ville chanter des poésies et surtout des morceaux détachés de l'Iliade et de l'Odyssée...

Rhapsoder - Terme vieilli. Mal raccommoder, mal arranger.

Rhapsodique - Qui est formé de lambeaux, de fragments.
}

Littré

Rhapsodie $-\mathfrak{1}^{\mathbf{o}}$. Suite de morceaux épiques recites par les rhapsodes. $2^{2}$. Pièce instrumentale de composition très libre...

Petit Robert ${ }^{27}$

A variedade de sentidos presente nos verbetes de dicionário citados por Sarrazac compreende desde acepções artísticas - como aquelas relacionadas ao trabalho dos recitadores da obra homérica, na antiguidade grega, ou a uma composição musical livre - até a noção de remendo ou de "colcha de retalhos". No entanto, todos eles têm em comum o fato de associarem ao termo rapsodo a idéia de uma composição que é fruto da junção de fragmentos, muitas vezes heterogêneos. Sem dúvida alguma, ao desenvolver o conceito de rapsódia - e todos os seus desdobramentos, uma vez que ele vai se afirmar "como um conceito transversal maior,

\footnotetext{
${ }^{27}$ SARRAZAC, Jean-Pierre. Epígrafe IN: O Futuro do Drama. Porto: Campo das Letras, 2002. Como na tradução portuguesa do livro, optei por manter a citação no original. Segue-se minha tradução: "Remendo - ação de remendar, de coser mal. // Rapsodo - termo da antiguidade grega. Nome dado àqueles que iam de cidade em cidade cantar poesias e, sobretudo, recitar trechos da Ilíada e da Odisséia.//Remendar - termo antigo. Coser mal, arranjar mal arranjado.//Rapsódico - que é formado de retalhos, de fragmentos [Dicionário Littré]. Rapsódia - ํㅜ․ Seqüência de trechos épicos recitados por rapsodos. $2^{\circ}$. Peça instrumental de composição bastante livre [Dicionário Petit Robert]"
} 
que se declina em uma série de termos operatórios e culmina na constituição de uma verdadeira constelação rapsódica ${ }^{28 ”}$ - Sarrazac explicita a proximidade da rapsódia com o domínio do épico, território "dos cantos e da narração homéricos e, ao mesmo tempo, dos procedimentos de escritura tais como a montagem, a hibridação, a costura, a coralidade ${ }^{29 "}$.

Ainda que o conceito mantenha uma proximidade com esse território, a idéia de constelação rapsódica é mais ampla, pressupondo um "transbordamento rapsódico" que ultrapassa o domínio do épico e coloca a rapsódia sob o signo da polifonia (SARRAZAC, 2005: 185), da qual Bakhtin "mostrou os principais traços: gosto pela miscelânea, pela pluralidade, pela heterogeneidade, pela inversão dos gêneros e das vozes $^{30}$. Dessa perspectiva, o trabalho que o escritor rapsódico realiza sobre a forma teatral "adquire todo o seu sentido, engendrando, nas escrituras contemporâneas, a estrutura de uma 'montagem dinâmica' [da qual] pode surgir a voz rapsódica ${ }^{31 ”}$. Voz que, segundo Sarrazac, é caracterizada, sobremaneira, pela explosão do diálogo, pela coralidade ou pela multiplicação dos possíveis, sendo "irremediavelmente errante e difratada, votada ao [...] questionamento incessante ${ }^{32 ”}$.

Ao definir a noção de escrita rapsódica como eixo central da análise que traça da dramaturgia contemporânea, Sarrazac evidencia o interesse em abordá-la a partir de sua estrutura fragmentada, em oposição à estrutura totalizante típica da forma dramática: ele opõe à metáfora corrente do dramaturgo como arquiteto (que opera com grandes unidades estruturais), a metáfora do escritor rapsodo, "que junta o que previamente despedaçou e, no mesmo instante, despedaça o que acabou de unir ${ }^{33}$ ". Mas também evidencia o interesse em fortalecer uma visada histórica das categorias estéticas - daí o seu alinhamento com a teoria brechtiana, para a qual, como Sarrazac

\footnotetext{
${ }^{28}$ SARRAZAC, Jean Pierre. Rhapsodie IN: Lexique du drame modern et contemporain. Belval: Les éditions Circé, 2005, p. 184. Tradução minha do original, em francês: "comme um concept transversal majeur, qui se décline en une série de termes opératoires, aboutisssant à la constitution d'une véritable constellation rhapsodique".

${ }^{29}$ Ibidem. Tradução minha do original, em francês: "des chants et de la narration homériques, en même temps qu'à des procédés d'écriture tels que le montage, 1 'hybridation, le rapiéçage, la choralité”.

${ }^{30}$ Ibidem: 185. Tradução minha do original, em francês: "en a montré les principaux traits: goût pour le mélange, la pluralité, l'hétérogénéité, le renversement des genres et des voix".

${ }^{31}$ Ibidem: 186. Tradução minha do original, em francês: "prend tout son sens, engendrant dans les écritures contemporaines la structure d'un 'montage dynamique' [dont] peut surgir la voix rhapsodique". ${ }^{32}$ Ibidem. Tradução minha do original, em francês: "irrémédiablement errante et diffractée, vouée au [...] questionnement incessant".

${ }^{33}$ SARRAZAC, 2002: 37 .
} 
mesmo lembra, "não basta dizer coisas novas, é preciso, também, dizê-las de outra forma ${ }^{34 "}$ - porque, para ele (SARRAZAC, 2002: 34), uma escrita contemporânea não se contenta em registrar as transformações ocorridas na sociedade, mas intervém diretamente na "conversão das formas".

Talvez seja essa, na visão do teórico francês, a maior contribuição de Brecht para o teatro: ao propor um modelo teórico de dramaturgia que questionasse a forma orgânica, preconizada por Aristóteles (a fábula de uma peça de teatro deve corresponder, para o autor da Poética, ao "belo animal", do qual deve ter não só as proporções, como também a unidade), Brecht abriu caminho para uma "estética do descontínuo 35 ", na qual do dramaturgo já não se exige mais que se restrinja a produzir rígidas imitações da natureza, mas obras contra naturam, híbridas, monstruosas ${ }^{36}$. Segundo Sarrazac, a parábola do drama moderno vem de Kafka que, no conto Cruzamento, descreve uma criatura metade gato, metade cordeiro. Não o fruto de uma miscigenação, como a mula o é do cruzamento que ocorre entre a égua e o jumento, mas uma criatura na qual as partes permanecem discretas, separadas uma da outra (SARRAZAC, 2002: 56). Para ele, nas obras híbridas se revela o gesto que o dramaturgo, na categoria de rapsodo, produz em direção ao futuro do drama, a prática da vivissecção: “cortar e cauterizar, coser e descoser, como se da mesma atitude se tratasse, o corpo do drama ${ }^{37 "}$.

Não pretendo, aqui, desconsiderar a perspectiva apontada por Luiz Fernando Ramos na direção de traçar uma poética do espetáculo que seja autônoma em relação a uma poética do dramático e que se oponha, de certo modo, a uma perspectiva ainda teológica do texto e da dramaturgia ${ }^{38}$, seja ela de tradição aristotélica ou marxista. Também não ignoro as importantes contribuições que deram, para uma "estética do descontínuo" - tanto no campo da dramaturgia como no campo da cena - dramaturgos anteriores ou contemporâneos a Brecht, como, por exemplo, Beckett, considerado por Heuvel um precursor da escrita teatral contemporânea. Mas, aqui, o intuito é perceber de que modo Brecht vai influenciar, diretamente, o pensamento da criação coletiva e

\footnotetext{
${ }^{34}$ Ibidem: 34 .

35 Ibidem: 56 .

${ }^{36}$ Ibidem.

${ }^{37}$ Ibidem: 54 .

${ }^{38}$ Ramos aponta a influência da ópera wagneriana e do pensamento cênico de Craig como crucial para as transformações que, de certo modo, vão ser atribuídas por Sarrazac a Brecht.
} 
contribuir para a consolidação do conceito - e sua aplicação nos processos coletivos de criação dramatúrgica - de dramaturgia da cena.

Assim como Ramos, Bernard Dort ${ }^{39}$ considera que a história do teatro contemporâneo é melhor descrita pela atividade dos encenadores do que pela obra dos dramaturgos. Remetendo à distinção traçada por Roger Planchon ${ }^{40}$ entre a escrita dramatúrgica e a escrita cênica, Dort afirma que, sem dúvida alguma, "é nos textos escritos por nossos encenadores, e não por dramaturgos, que se esboça, de forma mais ampla, a problemática do nosso teatro ${ }^{41}$ ”. Entretanto, ele salienta não só a necessidade da existência de uma ligação profunda entre essas duas escritas, mas evidencia também o papel que Brecht, como dramaturgo e encenador, exerceu sobre todo o teatro europeu.

O trabalho de Brecht é significativo desta promoção do encenador ao domínio da criação artística: em Brecht, encenação e composição dramática estão ligadas, não podem ser separadas. Para ele, escrever uma peça e encenála eram dois movimentos de um único e mesmo ato. A extraordinária influência exercida [...] pelo Berliner Ensemble sobre todo o teatro europeu, em grande parte, vem deste fato: em seus espetáculos a realização cênica não resulta somente de um equilíbrio ou de uma unidade do texto à iluminação, passando pela interpretação dos atores - possui coerência e significação próprias. Não se limita a traduzir, explica. Então a representação teatral constitui realmente uma obra autônoma - uma obra cujo autor é o encenador (DORT, 2010: 63).

Para Dort, as reflexões de Brecht, expressas sobretudo em seus Estudos sobre teatro $^{42}$, vão se referir, mais do que ao texto ou à encenação em si, ao que se poderia chamar de dramaturgia da encenação, isto é, "às relações que unem texto e encenação e o sentido que irá adquirir a obra em contato com o palco, através da intervenção dos atores diante de um público dado, em circunstâncias históricas e sociais determinadas" (DORT, 2010: 64).

\footnotetext{
${ }^{39}$ DORT, Bernard. O teatro e sua realidade. São Paulo: Perspectiva, 2010, pp. 63-64.

${ }^{40}$ Durante uma conferência realizada em Sorbonne em 1960 e intitulada Comment jouer Brecht? (DORT, 2010: 300).

${ }^{41}$ Ibidem: 64 .

${ }^{42}$ BRECHT, Bertolt. Estudos sobre teatro. Rio de Janeiro: Nova Fronteira, 2005.
} 
Segundo Pavis ${ }^{43}$, é justamente a partir de Brecht que o termo dramaturgia passa a abarcar toda a estrutura não só formal, mas também ideológica de uma peça e, em uma acepção "pós-brechtiana”, dramaturgia vai se referir não somente à estrutura textual, mas também aos meios cênicos empregados para levar esse mesmo texto ao espectador, ou seja, para produzir determinado efeito sobre ele (PAVIS, 1999: 113). Assim, para Brecht, a dramaturgia épica designaria uma forma teatral e não somente textual. Como salienta Pavis, "estudar a dramaturgia de um espetáculo é, portanto, descrever sua fábula 'em relevo', isto é, na sua representação concreta, especificar o modo teatral de mostrar e narrar um acontecimento ${ }^{44 ”}$ e, nesse sentido, dramaturgia "consiste em instalar os materiais textuais e cênicos, em destacar os significados complexos do texto ao escolher uma interpretação particular, em orientar o espetáculo no sentido escolhido ${ }^{45 "}$.

Contudo, é necessário lembrar que essa forma de atividade dramatúrgica, própria do dramaturg, já existia na Alemanha bem antes de Brecht. Segundo Pavis ${ }^{46}$ e Carlson ${ }^{47}$, a figura do dramaturg existe desde o século XVIII - persistindo até os dias de hoje - e tem origem em Lessing, a partir tanto de sua prática teatral, exercida principalmente no Teatro Nacional de Hamburgo, como da coletânea de reflexões teóricas e críticas que Lessing escreveu - a Dramaturgia de Hamburgo (1769) - e na qual, além de informar o público sobre as peças que eram apresentadas no recémcriado Teatro Nacional de Hamburgo, ele abordava questões de teoria e técnica dramática, fornecendo a base crítica para o estabelecimento do moderno teatro alemão (CARLSON, 1997: 163).

Responsável pela "atividade teórica e prática que precede e determina a encenação de uma obra”, o dramaturg (ou dramaturgista ${ }^{48}$ ) funciona como uma espécie de conselheiro literário e teatral, trabalhando junto a uma instituição, a um

\footnotetext{
${ }^{43}$ PAVIS, Patrice. Dicionário de Teatro. São Paulo: Perspectiva, 1999. Verbete Dramaturgia, p. 113.

${ }^{44}$ Ibidem.

${ }^{45}$ Ibidem.

${ }^{46}$ PAVIS, op. cit., verbete Dramaturgo, p. 117.

${ }^{47}$ CARLSON, Marvin. Teorias do Teatro: estudo histórico-crítico, dos gregos à atualidade. São Paulo: Editora UNESP, 1997.

${ }^{48}$ Ao contrário da França, em que uma única palavra, dramaturgo (ou dramaturge), designa tanto o autor de peças de teatro como o responsável por sua preparação para a realização cênica, na Alemanha existem dois termos: dramatiker - para o primeiro sentido - e dramaturg, para a segunda acepção (PAVIS, 1999: 117). No Brasil, dramaturg é traduzido, comumente, por dramaturgista, sendo a palavra dramaturgo normalmente empregada para designar aquele que escreve as peças.
} 
encenador ou a um grupo de teatro (PAVIS, 1999: 117). Segundo Nicolete Abreu ${ }^{49}$, o diretor Erwin Piscator salientava não só a presença do profissional em sua equipe, como também a necessidade de seu alinhamento ideológico, a fim de que o dramaturgista pudesse exercer, de fato, uma colaboração artística efetiva com ele ou com o dramaturgo do trabalho. O próprio Brecht, segundo ela, fez parte, no começo de sua atividade teatral, do laboratório dramatúrgico responsável "pelo desenvolvimento ou estudo de textos a serem montados" pela equipe de Piscator e, mais tarde, ao fundar o Berliner Ensemble - juntamente com sua esposa, a atriz Hélène Weigel - ele teria instituído, “de vez, a prática do dramaturgismo" (NICOLETE ABREU, 2005: 16).

Para Bernard Dort ${ }^{50}$, é sobretudo ao trabalho realizado no Berliner Ensemble de grande influência sobre os encenadores franceses - que se deve à instituição bem mais recente do dramaturgismo, na França, como uma atividade distinta daquela realizada pelos encenadores. No entanto, apesar do dramaturgista atualmente se constituir como um setor de atividade específica, ele não é, como salienta Michèle Raoul-Davis $^{51}$ - dramaturgista da equipe do encenador Bernard Sobel, no Centre Dramatique National de Gennevilliers - absolutamente visto como um profissional indispensável em um processo de encenação, sendo antes, para o encenador, "um cúmplice remunerado”, cuja presença é justificada somente por seu desejo (ou por sua necessidade) de ter um dramaturgista como interlocutor ou parceiro (RAOUL-DAVIS, 1986: 4).

No estudo que realiza sobre as funções do dramaturgista no âmbito da encenação - tanto no contexto europeu quanto no brasileiro - Magali Helena de Quadros $^{52}$ considera, em relação ao vínculo existente entre o encenador e o dramaturgista, que este pode atuar "como um aconselhador, desde a escolha da peça adequada, até os últimos ensaios" e que dentre as inúmeras possibilidades de sua atuação estão a proposição de peças a serem encenadas, a parceria na distribuição dos

\footnotetext{
49 NICOLETE ABREU, Adélia Maria. Da Cena ao Texto Teatral: dramaturgia em processo colaborativo. Dissertação (Mestrado em Artes Cênicas) - Escola de Comunicações e Artes da USP, 2005 , p. 16.

50 DORT, Bernard. L'état d'esprit dramaturgique IN: Revista Thêatre/Public: Dramaturgie. Gennevilliers, no 67, jan-fev 1986, pp. 8-12.

${ }^{51}$ RAOUL-DAVIS, Michèle. Profession Dramaturge IN: Revista Thêatre/Public: Dramaturgie. Gennevilliers, no 67, jan-fev 1986, pp. 4-6.

${ }^{2}$ QUADROS, Magali Helena de. Buscando compreender a função de dramaturgista. Dissertação (Mestrado em Teatro) - Programa de Pós-Graduação em Teatro da UDESC, 2007.
} 
papéis aos atores e a pesquisa do contexto e dos sentidos complexos do texto teatral, ajudando o encenador a encontrar "os significados pretendidos" (QUADROS, 2007: 43). Ela, no entanto, destaca que a função mais importante do dramaturgista talvez seja “auxiliar na preparação conceitual da encenação 53 ”, atividade ressaltada não só por ela, mas também por diversos estudiosos, desde Piscator até Pavis e Dort.

Durante o processo de encenação de uma obra, não raramente o dramaturgista pode ultrapassar uma função meramente conceitual ou teórica e se tornar responsável também pela transcriação ${ }^{54}$ do texto dramatúrgico, isto é, por sua adaptação ao contexto de recepção, contemporâneo ao projeto de montagem. Nas palavras de Nicolete Abreu (2005: 17), "além do trabalho sobre um texto já pronto, o dramaturgista pode também se encarregar da escrita, adaptação ou tradução de um texto”, assumindo a responsabilidade de "confeccionar, organizar, estruturar o roteiro ou texto, além de amparar os estudos teóricos necessários à montagem”. Esse fenômeno é perceptível em uma gama de processos de encenação vivenciados por coletivos teatrais brasileiros pode-se mencionar, por exemplo, o trabalho desenvolvido por Cacá Brandão em diversas montagens do Grupo Galpão, como Romeu e Julieta e Molière Imaginário ${ }^{55}$ nos quais o dramaturgista assume a autoria do texto final da encenação. Para Nicolete Abreu $^{56}$, nesse caso - diferentemente da escrita de um texto original, feita por um dramaturgo - como o texto "é fruto de pesquisa, compilação, colagem, adaptação, improvisação e texto mínimo dos atores", o responsável por esse trabalho dramatúrgico recebe o nome de dramaturgista e, seu ofício, o de dramaturgismo (NICOLETE ABREU, 2002: 58).

\footnotetext{
${ }^{53}$ Ibidem: 43 .

${ }^{54}$ O termo transcriação, oriundo da Teoria da Literatura, foi cunhado por Haroldo de Campos para designar a operação de tradução poética, a partir do dogma da "intraduzibilidade" da poesia, afirmado por Jakobson. Segundo este, sendo a poesia intraduzível, só é possível realizar uma operação de "transposição criativa" da obra original para outro contexto (cultural ou linguageiro). É nesse mesmo sentido que o termo vem sendo utilizado, nos estudos teatrais, para designar a operação de adaptação de um texto a outros sistemas semióticos, principalmente no que concerne à passagem da narrativa para o teatro, ou seja, da literatura para o palco. O volume 9 da revista O Percevejo (do Programa de PósGraduação em Teatro da UNIRIO) vai tratar, especificamente, das relações entre teatro e narrativa e traz artigos bastante esclarecedores para a questão.

${ }^{55}$ Esse trabalho dramatúrgico é descrito por Cacá Brandão no livro 1 (Romeu e Julieta) e no livro 3 (Um Molière Imaginário) do Diário de Montagem do Grupo Galpão.

BRANDÃO, Carlos A. Leite. Grupo Galpão: Diário de Montagem. Belo Horizonte: UFMG, 2003.

${ }^{56}$ NICOLETE ABREU, Adélia Maria. O Texto Teatral: reflexões sobre alguns processos de criação da dramaturgia contemporânea. Monografia (Especialização em Educação) - Centro Universitário de Santo André, 2002, p. 58.
} 
Na prática, Brecht conjugava as duas funções. Ou melhor, as três: encenador, dramaturgista e dramaturgo, ele não só escrevia peças originais, como também realizava releituras críticas de clássicos da dramaturgia - são exemplares as releituras cênicas de Antígona, de Sófocles ou de Coriolano, de Shakespeare - e transcriações de argumentos, óperas ou peças teatrais já existentes, como Aquele que diz sim, lehrstücke (peça didática) transcriada a partir da peça Nô Taniko. O processo de criação de Aquele que diz não - "reescrita que não era simplesmente uma inversão da primeira peça, havendo no novo texto aspectos que redimensionam dialeticamente a situação dramática ${ }^{57}$ - é bastante esclarecedor em relação à processualidade dramatúrgica de Brecht. Segundo Bernard Dort (2010: 295), após Brecht escrever a primeira versão da peça, musicada por Kurt Weill, ela foi representada para os alunos da escola Karl Marx e estes foram questionados em relação ao seu conteúdo, no intuito de apurar se davam ou não razão à decisão da criança de sacrificar sua vida para salvar a cidade, em nome do Grande Costume. O ponto de vista dos estudantes em relação a essa decisão levou Brecht a produzir uma segunda versão da obra, na qual a criança diz "não”, abolindo, assim, o Grande Costume e instaurando outro, no qual ninguém mais é sacrificado "pela salvação hipotética de todos em nome de uma natureza qualquer ${ }^{58}$ ".

Esse exemplo de intervenção do público no processo criador de Brecht evidencia, para além do aspecto processual das transformações que são operadas em sua escrita e na encenação de suas obras, a importância da mediação do espectador para o desenvolvimento da dramaturgia brechtiana. De fato, como salienta Dort (2010: 295), os principais elementos constitutivos do teatro épico - posso citar, como exemplos, a processualidade, a historicidade, a contradição e o procedimento de montagem (ou série de possibilidades) - vão assumir total eficácia na sua relação com o espectador.

No que tange à importância da experimentação cênica em relação à sua processualidade dramatúrgica, para Brecht, não se trata nem somente de reescrever o texto a partir dos possíveis ganhos impressos à dramaturgia pelo trabalho de encenação, mas de produzir uma dramaturgia a partir das possibilidades apresentadas

\footnotetext{
${ }^{57}$ PINTO, Davi de Oliveira. Nossa Pequena Mahagonny: aspectos processuais de uma dramaturgia colaborativa. IN: Cena Invertida, dramaturgias em processo. Belo Horizonte: Edições CPMT, 2010, p. 29. ${ }^{58}$ DORT, 2010: 295 .
} 
pelos elementos materiais da cena e pela exploração das potencialidades de cada situação (SARRAZAC, 2002: 64). Trata-se, antes, de criar "um teatro dos possíveis".

Segundo Sarrazac, a primeira intuição de um teatro dos possíveis - termo que utiliza para designar as estruturas dramatúrgicas propostas por André Benedetto, nas quais a dramaturgia, "impelida pela incessante meditação do autor sobre as personagens e sobre a fábula, (...) progride por hipóteses que se vão substituindo umas às outras ${ }^{59 "}$ - está justamente em Brecht. Segundo o teórico francês, a técnica de representação que o dramaturgo/encenador propõe aos atores - método que Brecht designa como "determinação do não-antes-pelo-contrário ${ }^{60 " ~-~ v a i ~ p e r m i t i r ~ q u e, ~ p o r ~}$ meio da atuação - "sempre em função do que faz ${ }^{61}$ - o ator possa não só descobrir, mas também sugerir e revelar aquilo que não faz. É especialmente notável que Brecht utilize o verbo descobrir, em primeiro lugar. O ato/gesto de descobrir, desvelar, em perfeita consonância com o conceito de distanciamento, peça-chave da teoria brechtiana $^{62}$.

Em tudo o que é evidente, é hábito renunciar-se, muito simplesmente, ao ato de compreender. O que era natural tinha, pois, de adquirir um caráter sensacional. Só assim as leis de causa e de efeito podiam ser postas em relevo. Os homens tinham que agir de determinada forma e poder, simultaneamente, agir de outra (BRECHT, 2005: 66).

O engajamento do ator é, nesse sentido, condição sine qua non para o seu trabalho de atuação, pois, para Brecht (2005: 106), caberá ao ator - e à encenação, como um todo - tornar visível uma alternativa, "de forma que a representação deixe prever outras hipóteses e apenas apresente uma entre as variantes possíveis". Em outras palavras, diferentemente do dramático, no qual a relação entre o autor e sua composição poética "não é parte essencial do seu caráter de obra” (SZONDI, 2001: 30),

\footnotetext{
${ }^{59}$ SARRAZAC, 2002: 63.

${ }^{60}$ BRECHT, op. cit., p. 106.

${ }^{61}$ Ibidem.

${ }^{62}$ Apesar das oposições entre Brecht e a teoria aristotélica, considero importante lembrar que na tragédia grega, segundo Aristóteles, o processo de conhecimento estava associado à anagnoris, ou seja, ao processo de reconhecimento - de descoberta, de desvelamento - de algo que, embora familiar, era percebido como estranho. Em outras palavras, tornar estranho o familiar era crucial para o processo de reconhecimento que levava ao conhecimento.
} 
no teatro épico as diversas perspectivas sobre a situação apresentada constituem o próprio tecido dramatúrgico. Bernard Dort, ao descrever o trabalho realizado pelo Berliner Ensemble - presenciado por ele na primeira visita do grupo à França, em 1954, e em ocasiões posteriores - salienta a multiplicidade não só dos elementos que constituem a encenação, como também das relações criativas que a produzem e sustentam.

Muito mais do que um estilo de teatro, o que temos diante de nós é aquilo que Roger Planchon chamou [...] de escrita cênica. A obra se realiza plenamente numa linguagem em que todos os elementos (cada acessório, cada gesto e cada movimento dos atores) são significativos [...]. Assim, um espetáculo do Berliner Ensemble se constitui a partir dos mais diversos elementos. Da utilização do cenário em seu conjunto, ao realismo minucioso dos objetos, passando pelo jogo múltiplo, constantemente "quebrado" dos atores, [ele] confronta todos os estilos do teatro contemporâneo. [...] Um trabalho deste tipo evidencia também [...] um caráter coletivo. [...] A encenação não é mais o privilégio de uma só pessoa; o teatro perde seu caráter de competição entre personalidades que só pensam em impor suas singularidades. Neste trabalho coletivo, cada um observa o outro, cada um ajuda e é ajudado pelo outro. Certamente existem [...] rivalidades [...], mas estas tensões [...] não prejudicam o essencial: a multiplicidade de reflexões cuja soma e organização resultam num espetáculo, a riqueza de um trabalho onde experiências diversas são confrontadas, em vez de serem submetidas à vontade onipotente do encenador, tornado rei, e por ele empobrecidas" (DORT, 2010: 300-305).

Em outras palavras, no teatro brechtiano é inaugurado, precisamente, o conceito de dramaturgia coletiva da cena, uma vez que a atividade dramatúrgica já não diz respeito somente à composição do texto escrito. No teatro épico, além da processualidade dramatúrgica estar intrinsecamente relacionada à criação do espetáculo - teatralidade e textualidade como faces da mesma moeda - e de toda a equipe de montagem se tornar responsável pela criação da obra cênica como um todo (NICOLETE ABREU, 2002: 12), é exigido também que o espectador tome parte na criação. Pode-se dizer que, a partir de Brecht, não só “o palco começa a narrar”, como, 
por conseqüência - uma vez que se conta com o seu despertar crítico - o espectador entra em atividade.

\subsection{Texturas da cena}

Com efeito, a partir da teoria brechtiana parece haver, para a criação dramatúrgica, uma íntima relação não mais somente entre conteúdo e forma - como na teoria de Szondi - ou entre a poética do dramático e a poética do espetáculo (forma e forma) - conforme a perspectiva de Ramos - mas também entre formas e modos de produção, ou seja, é colocada em questão a maneira como as relações entre os criadores, durante o processo de criação, interferem na forma teatral resultante. Podese afirmar, na esteira de Sarrazac, que o processo de criação da dramaturgia de uma encenação passa a atuar diretamente na conversão das formas dramatúrgicas e, em decorrência disso, nas relações entre textualidade, teatralidade e recepção, uma vez que, a partir do teatro épico, o espectador passa a ser considerado interlocutor privilegiado da cena.

Segundo Luiz Alberto de Abreu ${ }^{63}$, “a relação ‘olho no olho’ entre personagens no palco transfere-se para 'olho no olho' entre ator/narrador/personagem e público. A ponte obstruída pela 'quarta parede' é novamente aberta ${ }^{64 "}$, pois, ao privilegiar o diálogo ativo com o espectador, o sistema narrativo opera um deslocamento da ação teatral que, pensada na poética dramática como motor da relação intersubjetiva entre as personagens - da qual o espectador é testemunha e cúmplice, mas não participante - no teatro épico é pensada como uma prática - práxis - discursiva que, interpelando

\footnotetext{
${ }^{63}$ Dramaturgo responsável pela dramaturgia de O Livro de Jó, do Grupo Teatro da Vertigem, e professor da Escola Livre de Teatro de Santo André, Luís Alberto de Abreu tem coordenado, nos últimos dez anos, diversas experiências de criação colaborativa, como a Oficina de Dramaturgia e o projeto Cena $3 \times 4$, ambos realizados pelo centro cultural Galpão Cine Horto. Para ele, parece ser intrínseca a relação entre processos compartilhados de criação dramatúrgica e uma poética do texto que opere com um sistema narrativo, pois esta se reflete em sua prática teatral, pois ele tanto realiza dramaturgias colaborativas como privilegia, em sua poética, a linguagem rapsódica.

${ }^{64}$ ABREU, Luiz Alberto. A restauração da narrativa IN: O Percevejo, Revista de Teatro, Crítica e Estética do Programa de Pós-Graduação em Teatro da UNIRIO. Rio de Janeiro, ano 8, no 9, 200o, p. 124.
} 
diretamente o espectador, o convida a tomar uma atitude crítica e criadora em relação à cena.

O convite crítico-reflexivo feito ao espectador, nesse caso, pode ser compreendido como um retorno freqüente à própria consciência [...] para, desse lugar que lhe é próprio, elaborar um juízo de valor acerca dos acontecimentos levados à cena. [...] O princípio dramático se mostra interrompido, problematizado, cada vez que um elemento cênico se revela, cada vez que o teatro se apresenta enquanto tal, quebrando com a lógica do drama fechado. As brechas no mecanismo dramático rompem com a ficcionalidade irrestrita e expulsam o espectador da vivência interior da obra, lançando-o de volta à própria consciência, convidando-o a desempenhar um ato propriamente estético, reflexivo [...], para empreender um ato propriamente autoral e analítico ${ }^{65}$.

Contudo, questões concernentes às relações entre processo de criação, teatralidade e recepção e à perspectiva da textualidade como elemento material da cena, embora tenham sido inauguradas, na prática, pela dramaturgia brechtiana, não é atributo exclusivo do teatro épico. Já $\operatorname{Artaud}^{66}$ discutia, em outros termos, a necessidade de se buscar uma maior performatividade do teatro a fim de atingir, concretamente, o espectador. Ao colocar em questão a supremacia do sistema literário e da linguagem verbal em relação à materialidade cênica e à corporeidade ${ }^{67}$, dentro do teatro europeu, ele afirmava que a decadência do teatro - bem como de toda a cultura ocidental - se devia ao lugar de honra que, nele, era ocupado pelo texto e pelas convenções lógico-discursivas a ele atreladas. Para Artaud, a literatura funcionava como uma amarra na qual se prendia a linguagem teatral, estritamente cênica, e, nesse sentido, o uso do discurso verbal deveria, no teatro, ser calcado no poder que as palavras teriam de, por meio de sua modulação, ritmo e vibração, atingir a alma e o

\footnotetext{
${ }^{65}$ DESGRANGES, Flávio. Teatralidade tátil: alterações no ato do espectador IN: Sala Preta, revista do Programa de Pós-Graduação em Artes Cênicas. São Paulo: ECA/USP, n. 8, 2008, p. 14.

${ }^{66}$ Essas questões perpassam todo o pensamento de Artaud. As referências e citações utilizadas aqui são, principalmente, de: ARTAUD, Antonin. O teatro e seu duplo. São Paulo: Martins Fontes, 1999; ARTAUD, Antonin. Linguagem e vida. São Paulo: Perspectiva, 2004.

${ }^{6} \mathrm{O}$ pensamento artaudiano vai influenciar diretamente diversas manifestações cênicas - como a performance, o happening, o teatro performativo - em que o corpo é presença forte.
} 
corpo do espectador. Segundo ele, a performatividade da palavra não estaria ligada ao seu significado, mas à sua existência quase física, à sua materialidade.

Mais do que isso: na perspectiva de Artaud, o texto não é visto como um elemento prévio, origem e fonte de toda a encenação e em relação ao qual esta só poderia ser concebida como "uma segunda versão de um texto definitivamente escrito" (ARTAUD, 2004: 73). Pelo contrário: segundo ele, a encenação constituiria uma linguagem particular, na qual a importância do texto se igualaria a de todos os outros componentes cênicos e a palavra nasceria em estreita relação com a gênese da cena.

[...] Eu creio que o teatro só poderá voltar a ser ele próprio no dia em que os autores dramáticos mudarem completamente sua inspiração e, sobretudo seu meio de escritura. Para mim, a questão que se impõe é de se permitir ao teatro reencontrar sua verdadeira linguagem, linguagem espacial, linguagem de gestos, de atitudes, [...] de gritos e onomatopéias, linguagem sonora, mas que terá a mesma importância intelectual e significação sensível que a linguagem das palavras [...]. [Os] gestos, as atitudes, os signos, serão inventados à medida que forem pensados, e diretamente no palco, onde as palavras nascerão para rematar e concluir esses discursos líricos, feitos de música, de gestos e de signos ativos. (ARTAUD, 2004: 80).

Com uma perspectiva semelhante à de Artaud, no que se refere ao pensamento do teatro como uma linguagem estritamente cênica, Barba ${ }^{68}$ amplia a noção de texto e dramaturgia, ao considerar que a relação entre a cena - ou o trabalho que é operado por ela - e o espectador é elemento definidor da noção de ação, central para o seu conceito de dramaturgia. Segundo ele (BARBA \& SAVARESE, 1995: 69), "todas as relações, todas as interações entre as personagens ou entre as personagens e as luzes, os sons e os espaços, são ações. Tudo o que trabalha diretamente com a atenção do espectador em sua compreensão, suas emoções, sua cinestesia, é uma ação”. De maneira complementar, Barba afirma que as ações só são operantes quando elas estão em relação umas com as outras, entrelaçadas em uma textura, ou, em outras palavras, quando elas se tornam um tecido cênico: “a palavra 'texto', antes de se referir a um

\footnotetext{
${ }^{68}$ BARBA, Eugenio. \& SAVARESE, Nicola. A arte secreta do ator: dicionário de antropologia teatral. São Paulo, Campinas: HUCITEC, 1995, p. 69.
} 
texto escrito ou falado, impresso ou manuscrito, significa 'tecendo junto'. Nesse sentido, não há representação que não tenha texto".

Dessa perspectiva, a noção de dramaturgia corresponderia àquilo que, nos Estudos da Linguagem, é denominado como discurso teatral, o qual se diferencia do texto literário justamente por seu alto poder performativo - ou seja, por seu poder de realizar simbolicamente uma ação - e se caracteriza, basicamente, pela ação intencionada que exerce sobre o espectador (PAVIS, 1999: 103). Isso significa dizer que o discurso teatral é produzido na relação entre a cena - e todos os seus componentes e o espectador, uma vez que se trata de uma prática de enunciação e suas articulações discursivas $^{69}$. Segundo Charaudeau $^{70}$, como o discurso teatral não se reduz à manifestação verbal da linguagem, mas compreende os códigos da manifestação linguageira - isto é, de uma instância extra lingüística na qual se desenvolve a mise-enscène da significação - e pode utilizar-se de vários códigos semiológicos - tais como o icônico e o gestual - a mise-en-scène discursiva, no teatro, depende, então, das propriedades (ou características) de todos esses códigos e das relações que entre eles se estabelecem, ao atuarem em conjunto.

No vasto campo dos Estudos da Linguagem - que abarca desde a Semiologia até a Análise do Discurso e a Filosofia da Linguagem, na qual se inclui a Teoria dos Atos de Fala $^{71}$ - não somente as discussões referentes às noções de texto e discurso vão encontrar eco nas teorias sobre o teatro, como também a própria linguagem teatral vai se tornar, cada vez mais, objeto de discussão desses Estudos, influenciando diretamente o pensamento sobre a Linguagem. É exemplar o mútuo interesse que existe entre os estudos teatrais e as teorias pós-estruturalistas que, já na década de 6o, vão se debruçar, de modo especial, sobre as noções de textualidade, teatralidade e autoria e vão acabar por tecer parâmetros bastante pertinentes para se pensar as

\footnotetext{
${ }^{69}$ Em razão da complexidade do estatuto enunciativo do discurso teatral - que ocorre em vários níveis e compreende, principalmente, uma situação interna (relação interlocutiva entre os personagens) e uma situação externa (relação entre as instâncias reais: ator - ou ainda, instância produtora do discurso cênico da qual o ator é veículo - e espectador) - essa ação intencionada encontra-se, muitas vezes, mascarada.

${ }^{70}$ CHARAUDEAU, Patrick. Une analyse sémiolinguistique du discours IN: LANGAGES. Paris: Larousse, n. 117, 1995.

${ }^{71}$ Em Como fazer coisas com as palavras - texto inaugural da Teoria dos Atos de Fala - Austin vai abordar a função performativa da linguagem, por meio do estudo dos verbos performativos. Tal abordagem vai influenciar, diretamente, os estudos contemporâneos sobre a performance, que dela vão se apropriar para discutir a questão da performatividade.
} 
relações entre texto e cena no teatro contemporâneo. É possível citar, como exemplo, os escritos de Derrida sobre Artaud e uma boa parte da produção crítica de Barthes, para a qual a questão do teatro e da teatralidade é pedra fundamental.

Embora Barthes, ao discutir especificamente a noção de teatralidade ${ }^{72}$, pense o texto em certa oposição a ela - uma vez que a teatralidade é, segundo ele, justamente o teatro sem o texto, constituindo-se como uma "espessura de signos e sensações" que "submerge o texto sob a plenitude de sua linguagem exterior ${ }^{73}$ " - no que tange ao texto literário, Barthes vai contrapor, ao conceito de literatura, a noção de escritura. Assim, ele possibilita pensar o texto - antes atrelado ao enunciado verbal - como uma enunciação.

Dessa perspectiva, Barthes ${ }^{74}$ considera que o texto vai ser engendrado na relação entre a escritura - constituída por todo trabalho e toda prática de inscrição - e o leitor. Segundo ele, a escritura é gerada pela destruição do conceito de texto como intrinsecamente ligado ao impresso. Ao considerar o texto como um teatro da linguagem em que o escrever é um verbo intransitivo cujo fim é ele mesmo, cujo fim é o trabalho de inscrição, Barthes fatalmente desloca a noção de texto do conceito de obra fechada, acabada, resultante do processo de escrita do autor, para uma percepção mais ampla do texto como fruto da articulação entre a produção do scriptor e a dimensão interpretativa do leitor. Para ele (BARTHES, 2004: 61), o scriptor - ao contrário do autor antigo, que tem como pressuposto uma anterioridade em relação ao texto - nasce ao mesmo tempo em que nasce seu texto. Nesse sentido, o scriptor não precede ou excede sua escrita - ou melhor, seu gesto de inscrição - e não há outro tempo para além do tempo da enunciação: todo texto "é escrito eternamente aqui e agora”. Ou seja, para Barthes, escrever, mais do que uma operação de registro ou "pintura”, é uma operação performativa - uma enunciação cujo conteúdo é o próprio ato de enunciar - e o texto "um espaço de dimensões múltiplas, onde se casam e se contestam escritas variadas, nenhuma das quais é original75".

\footnotetext{
${ }^{72}$ BARTHES, Roland. Le théâtre de Baudelaire IN: Écrits sur le théâtre. Paris: Seuil, 2002, pp. 122-129.

${ }^{73}$ Ibidem : 122. Tradução minha, do original em francês: "épaisseur de signes et de sensations" qui "submerge le texte sous la plénitude de son langage extérieur".

${ }^{74}$ BARTHES, Roland. A morte do autor IN: O rumor da língua. São Paulo: Martins Fontes, 2004, pp. 5864 .

${ }^{75}$ Ibidem: 62.
} 
Mas há um lugar em que essa multiplicidade se reúne, e esse lugar não é o autor, como se tem dito até aqui, é o leitor: o leitor é o espaço exato em que se inscrevem, sem que nenhuma se perca, todas as citações de que uma escrita é feita; a unidade de um texto não está na sua origem, mas no seu destino: o leitor é [...] apenas esse alguém que tem reunidos num mesmo campo todos os traços que constituem o escrito (BARTHES, 2004: 64).

Ao deslocar a unidade do texto do autor para o leitor, Barthes vai permitir que se conceba tanto a dramaturgia - como prática textual e cênica - quanto o texto resultante desta operação, como um espaço em que se reúnem dimensões múltiplas, originadas no embate entre as diversas escritas, ou melhor, entre os diversos gestos de inscrição que, livres da determinação de um autor-deus, vão compor o tecido dramatúrgico: o gesto do dramaturgo, mas também o gesto do ator, do encenador e de todas as funções vinculadas à sua criação. Em outras palavras, pode-se afirmar que a dramaturgia, ao ser concebida como uma escritura, resulta em uma operação entre textos, em uma tessitura intertextual que vai ser constituída por muitos gestos de enunciação, todos em permanente diálogo. Nesse sentido, Barthes aponta para a destruição do autor, que morre ao mesmo tempo em que nasce o leitor/espectador como o espaço onde se reúne todos os gestos de que a escritura é feita. Mas aponta, também, para a possibilidade da dramaturgia ultrapassar os limites da autoria e da literatura e, não mais vinculada estreitamente a um suporte de papel, ganhar o estatuto de textura da cena, corroborando não somente a teoria brechtiana e o pensamento, em certa medida, de Artaud, mas também a perspectiva de Barba, pois, ao se conceber a dramaturgia como textura cênica, torna-se possível pensá-la, então, não como enunciado, mas como uma enunciação ${ }^{76}$ necessariamente coletiva e polissêmica (a morte do autor pressupõe a polissemia do texto ${ }^{77}$ ). E pensar a dramaturgia como enunciação coletiva, isto é, como um texto que se tece junto, implica em pensá-la no âmbito da criação compartilhada da cena.

\footnotetext{
${ }^{76}$ Segundo Barthes, "a enunciação é inteiramente um processo vazio que funciona na perfeição sem precisar ser preenchido pela pessoa dos "interlocutores". Linguisticamente, o autor nunca é nada mais para além 'daquele que escreve', tal como 'eu' não é senão aquele que diz eu: a linguagem conhece um 'sujeito', não uma 'pessoa', e esse sujeito, vazio fora da própria enunciação que o define, basta para fazer 'suportar' a linguagem, quer dizer, para a esgotar" (BARTHES, 2004: 62).

${ }^{77}$ BARTHES, 2004: 64.
} 


\subsection{Dramaturgia coletiva, autoria compartilhada}

Dentro da maior parte do pensamento teatral produzido no século XX - de Gordon Craig e Artaud a Renato Cohen, de Roger Planchon a Robert Wilson - a idéia mais ou menos radical - do encenador como mente única, origem da criação teatral, é recorrente. Para Gordon Craig, por exemplo, o teatro, a fim de se constituir como obra de arte autônoma, não deveria se subordinar a nenhum domínio artístico específico, inclusive ao texto. Para isso, a encenação - ao contrário do que sonhava Wagner - não poderia ser fruto da comunhão de diversas artes (ou artistas), mas resultante da técnica particular de um único criador que, reunindo em si todas as qualidades de um "mestre do teatro", engendraria não somente sua própria arte - uma arte independente e criadora, a arte do encenador - mas, ainda, a renovação do teatro ${ }^{78}$.

Tradicionalmente um lugar ocupado pelo dramaturgo, com a consolidação da idéia de que a escrita cênica se constituiria como uma obra autônoma em relação ao texto escrito, do qual, em uma perspectiva anterior, ela deveria emergir, o encenador se tornou o grande eixo do espetáculo, passando a exercer uma função estruturante na concepção da obra teatral. Segundo Pavis (1999: 132), a escrita cênica é, justamente, a encenação "assumida por um criador que controla o conjunto dos sistemas cênicos, inclusive o texto, e organiza suas interações, de modo que a representação não é o subproduto do texto, mas o fundamento do sentido teatral". Desse ponto de vista, é possível afirmar que não somente a poética espetacular se consolidou como o novo paradigma do século XX - em oposição à poética do texto - como também o encenador, tornando-se o "responsável pela criação de um sistema cênico regido por leis próprias ${ }^{79 ”, ~ f o i ~ a l c ̧ a d o ~ a ̀ ~ c o n d i c ̧ a ̃ o ~ d e ~ a u t o r ~ d o ~ e s p e t a ́ c u l o . ~}$

Contudo, a partir dos anos 6o, a criação coletiva, manifestada por vários grupos como, por exemplo, Living Theather, Thêatre du Soleil, Teatro La Candelaria, TEC -

\footnotetext{
${ }^{78}$ CRAIG, Edward Gordon. De l'Art du Théâtre. Paris: Éditions Lieutier, 1942, p. 123.

${ }^{79}$ SILVA, Antônio C. de Araújo. A encenação no coletivo: desterritorializações da função do diretor no processo colaborativo. Tese (Doutorado em Artes Cênicas) - Escola de Comunicações e Artes da USP, 2008, p. 181.
} 
Teatro Experimental de Cali - e, no Brasil, União e Olho Vivo, Pod Minoga e Asdrúbal Trouxe o Trombone, entre outros, respondeu - e continua respondendo - a uma necessidade de descentralização das figuras do dramaturgo e do encenador, tidos, até então, como os demiurgos da cena; e a uma necessidade geral de temas que abrangessem o momento histórico no qual viviam os atores - sobretudo eles, pois eram desprivilegiados no cenário das decisões artísticas - e seus grupos teatrais. Com a proliferação de espetáculos construídos em um sistema de criação coletiva, principalmente nas décadas de 6o e 70, abriu-se um campo fértil para a investigação de uma dramaturgia que fosse erigida a partir da criação atoral, como denota o texto Dramaturgia do Ator, de Enrique Buenaventura, dramaturgo e diretor do Teatro Experimental de Cali.

Somente um processo de produção que organize a participação criadora dos atores em todas as etapas e níveis do discurso do espetáculo pode ser o genotexto de textos que não sejam meras imitações ou adaptações da tradição ou da vanguarda do teatro ocidental, de textos que elaborem sua linguagem e suas personagens a partir das realidades que vivemos aqui e agora, mediante essa assimilação de todas as influências que somente a maturidade de uma expressão artística nos dá ${ }^{80}$.

Em razão disso, houve também uma grande valorização da potência criadora do ator - para além de suas potencialidades interpretativas - e fortes estímulos para que este se tornasse um artista "total", da não-especialização: capaz de pensar, de propor, de criar e não apenas de "servir".

Para isso, é necessário passar da condição de "histrião" à condição de ator, da condição de intérprete à de criador que tem o direito e o dever de intervir

\footnotetext{
${ }^{80}$ BUENAVENTURA, Enrique. La dramaturgia del actor. www.teatrodelpueblo.org.ar (acessado em 20/03/2006). Tradução minha do original em espanhol: "Sólo un proceso de producción que organice la participación creadora de los actores en todas las etapas y niveles del discurso del espectáculo puede ser el genotexto de textos que no sean meras imitaciones o adaptaciones de la tradición o la vanguardia del teatro occidental, de textos que elaboren su lenguaje y sus personajes con las realidades que hoy y aquí vivimos, mediante esa asimilación de todas las influencias que solo da la madurez de una expresión artística”.
} 
(metodologicamente) em todos os níveis e aspectos do processo de produção do discurso do espetáculo e nas relações deste com o público ${ }^{81}$.

Para Antônio Araújo (SILVA, 2008: 27), além da significativa participação do ator no processo de criação do espetáculo, na criação coletiva estavam em jogo também, como "elementos estreitamente vinculados um ao outro”, “a abolição da função especializada e a polivalência artística”, ou seja, "um acúmulo de atributos em cada artista envolvido ou uma transitoriedade mais fluida das funções entre eles ${ }^{82}$ ". Essa perspectiva é corroborada por Sílvia Fernandes ${ }^{83}$, para quem a "diluição da divisão rígida entre funções artísticas", nos processos de criação coletiva, era decorrente da “intenção de fazer dos trabalhos o fruto da colaboração de cada participante”. Desse modo, todos "os participantes eram autores, cenógrafos, figurinistas, iluminadores, sonoplastas e produtores dos espetáculos" (FERNANDES, 2000: 14). Em outras palavras, pode-se dizer que, no âmbito da criação coletiva, a dramaturgia e a encenação passaram a ser funções assumidas pelo coletivo de artistas responsável pela obra em processo. Segundo Pavis (1999: 80), no trabalho coletivo ocorre o que Brecht denomina "socialização do saber": “a encenação não representa mais a palavra de um autor (seja este autor dramático, encenador ou ator), porém a marca mais ou menos visível e assumida da palavra coletiva”.

Nessa mesma direção, Roubine ${ }^{84}$ vai destacar, a partir do trabalho realizado pelo Teatro Laboratório, de Grotóvski ${ }^{85}$, a concepção de uma nova prática, na qual o texto não é mais a fonte da encenação - nem o é uma concepção cênica, produzida

\footnotetext{
${ }^{81}$ Ibidem. Tradução minha do original em espanhol: "Para ello es necesario pasar de la condición de "histrión" a la condición de actor, de la condición de intérprete a la de creador que tiene el derecho y el deber de intervenir (metodológicamente) en todos los niveles y aspectos del proceso de producción del discurso del espectáculo y en las relaciones de éste con el público".

${ }^{82}$ SILVA, Antônio C. de Araújo. A Gênese da Vertigem: o processo de criação de O Paraíso Perdido. Dissertação (Mestrado em Artes Cênicas) - Escola de Comunicação e Artes da USP, 2002, p. 101.

${ }^{83}$ FERNANDES, Sílvia. Grupos teatrais: anos 7o. Campinas: Editora da UNICAMP, 20oo, p. 14.

${ }^{84}$ ROUBINE, Jean-Jacques. A linguagem da encenação teatral. Rio de Janeiro: Jorge Zahar Ed., 1998, pp. 66-67.

${ }^{85}$ Segundo Grotóvski, o teatro é "um encontro entre pessoas criativas. Sou eu, o diretor, que me defronto com o ator, e a auto-revelação do ator me dá a revelação de mim mesmo. Os atores e eu nos defrontamos com o texto. [...] Para o ator e o diretor, o texto do autor é uma espécie de bisturi que nos possibilita [...] encontrar o que está escondido dentro de nós e realizar o ato de encontrar os outros: em outras palavras, transcender nossa solidão. [...] Para mim, criador de teatro, o importante não são as palavras, mas o que fazemos delas, o que confere vida às palavras inanimadas do texto" (GROTÓVSKI, Jerzy. Em busca de um teatro pobre. Rio de Janeiro: Civilização Brasileira, 1992, p. 50).
} 
anteriormente pelo encenador - mas emerge do trabalho criativo realizado na sala de ensaio, da comunhão entre corpo e voz do ator e a operação do diretor. Nesse sentido, não haveria mais a "necessidade de [se] recorrer a um texto-pretexto, a um texto anteriormente construído. De então em diante, é o conjunto de todos os que representam o texto que se constitui no seu autor coletivo". Roubine (1998: 77) salienta ainda que "estamos aqui diante de uma nova concepção de texto dramático. Não mais uma 'obra', mas aquilo que os anglo-saxões chamam de work in progress, um material aberto e transformável". Para ele, essa nova concepção de dramaturgia, produzida numa prática coletiva de criação, implicaria na discussão de um "cacife ideológico" ainda imperante no teatro, o status de "autor" da obra: "trata-se de saber em que mãos cairá o poder artístico, [...] a quem caberá tomar as opções fundamentais, e quem levará aquilo que antigamente se chamava glória" (ROUBINE, 1998: 45).

Como é perceptível, não é possível discutir a criação compartilhada sem levar em consideração a questão da autoria, já apontada por Barthes. Como ele, Foucault ${ }^{86}$ também vai discutir a função do autor. Para Foucault, no entanto, essa discussão não se restringe ao campo da linguagem, mas diz respeito a questões de ordem política e econômica. Ao colocar que o discurso "não era originalmente um produto, uma coisa, um bem: [que ele] era essencialmente um ato", e que ele foi "historicamente um gesto carregado de riscos antes de ser um bem extraído de um circuito de propriedades", Foucault afirma o pensamento da autoria - de modo inverso à perspectiva burguesa de propriedade intelectual - como ato transgressor. Em outras palavras, um processo compartilhado de criação teatral, ao colocar as relações criativas como um lugar de saberes socializados - a genealogia do saber é uma genealogia do poder - acaba por deslocar o conceito de autoria do sentido de propriedade e aponta para a criação como ato político. Guattari afirma:

O novo paradigma estético tem implicações ético-políticas porque quem fala em criação, fala em responsabilidade da instância criadora em relação à coisa criada [...]. Mas essa escolha ética não mais emana de uma enunciação transcendente, de um código de lei ou de um deus único e todo-poderoso. A

\footnotetext{
${ }^{86}$ FOUCAULT, Michel. O que é um autor? IN: Ditos e Escritos, III. Rio de Janeiro: Forense Universitária, 2006, p. 275.
} 
própria gênese da enunciação encontra-se tomada pelo movimento de criação processual $^{87}$.

A postura adotada pelos grupos, nessa época, era absolutamente política, apesar do tema nem sempre abordar fatos ou questões sociais. Como salienta Reinaldo Maia ${ }^{88}$, tratava-se de buscar uma nova "organização do coletivo de trabalho", relações produtivas que questionavam o modo vigente de organização (propícia a uma “acumulação capitalista ${ }^{89 ") ~ d a s ~ g r a n d e s ~ c o m p a n h i a s ~ t e a t r a i s . ~ S e g u n d o ~ e l e, ~ h a v i a ~ u m a ~}$ relação intrínseca entre o contexto histórico de surgimento da criação coletiva e a formação, no Brasil, de um pensamento político sobre a cena que, para além de uma abordagem temática, questionasse os modos de criação e produção teatral.

Sílvia Fernandes também aborda o problema das relações entre criação coletiva e atuação política, mas lança uma nova luz sobre a questão. Segundo ela (FERNANDES, 2000: 27), havia, na conjuntura ditatorial do país, um forte patrulhamento ideológico por parte de grupos engajados politicamente - ou seja, “comprometidos ideologicamente com determinados agrupamentos de esquerda” - em relação à validade das opções dramatúrgicas poéticas de grupos que buscavam, sob um sistema de criação cooperativado, a construção de uma linguagem própria, mas que não encenavam ou produziam, necessariamente, dramaturgias com temas sociais. Em resposta, alguns desses grupos - como o Pessoal do Victor, no exemplo citado por ela apontavam a flagrante contradição que existia entre o tema e o modo de produção de alguns espetáculos "engajados politicamente" - caso da montagem de Gota D'Água, produzida por Casa Grande em 1975 - pois, muitas vezes, as relações de opressão e exploração colocadas em cena estavam presentes no modo de organização trabalhista da própria montagem ${ }^{90}$.

A crítica atingia [...] toda a tendência da década de 70 de desenvolvimento de uma dramaturgia preocupada em discutir problemas do povo brasileiro. Apesar de elegerem como protagonista central o homem oprimido e explorado, as peças eram financiadas por produtores que, pagando salários

\footnotetext{
${ }^{87}$ GUATTARI, Felix. Caosmose: um novo paradigma estético. São Paulo: Editora 34, 1992, p. 137.

${ }^{88}$ MAIA, Reinaldo. Duas ou três coisinhas sobre o processo colaborativo. S/R (artigo inédito).

${ }^{89}$ Ibidem.

${ }^{90}$ Em entrevista concedida à pesquisadora, Paulo Betti, ator do grupo, levanta a questão.
} 
flagrantemente desiguais aos trabalhadores do espetáculo, tornavam a forma de produção um espelho das desigualdades criticadas no drama (FERNANDES, 2000: 28).

A democratização da criação cênica era um dos pontos mais defendidos por aqueles que sustentaram a iniciativa de uma criação compartilhada, pois esta propunha uma maior liberdade e uma efetiva coletivização dos modos de produção teatral. Dentro dessa perspectiva, a democratização não se restringia ao coletivo de artistas que produziam o espetáculo, mas se vinculava também ao desejo de uma participação coletiva mais ampla, o que incluía o âmbito da sociedade e, nesse sentido, a integração do espectador à obra teatral.

Na busca de uma nova relação com a platéia [...] procurou-se subverter a experiência de passividade por parte dos espectadores, de forma a que não se acomodassem enquanto convidados distantes da cena, mas que assumissem um papel mais ativo, crítico e integrado. No limite, almejou-se que o projeto artístico viesse a se configurar como uma criação de todos, rompendo-se a barreira entre artistas e público. Tal objetivo fez com que vários grupos deixassem os palcos italianos e criassem espetáculos e intervenções em ruas e praças, na busca de um contato direto com os transeuntes-espectadores. Procurava-se com isso, também, atingir e conscientizar criticamente um público que jamais iria ao teatro. Neste desejo de "participação" encontrava-se embutido um projeto utópico de transformação da realidade (ARAÚJO, 2008: 29).

São exemplares dessa perspectiva de coletivização do projeto artístico, o trabalho realizado por importantes grupos do período que, operando em um sistema de criação coletiva, produziram algumas das obras teatrais mais significativas e representativas de sua própria época, como as emblemáticas Paradise Now, realizada em 1968 pelo Living Theater, 1789, realizada em 1970 pelo Théâtre du Soleil e, no Brasil, Gracías Señor, trabalho que estreou em 1971, inaugurando uma nova fase do Teatro Oficina. A montagem era apresentada em 12 horas e durava duas noites. 
Estreado em 15 de maio de 1971, em Brasília, o novo trabalho do Oficina foi apresentado para um público de 5 mil pessoas que acompanharam, no campus da Universidade local, os atores desenvolverem o que já não se pretendia mais ser um espetáculo teatral, mas, sim, um rito de passagem. Havia um roteiro prévio, mas nesse rito em que se projetava a esquizofrenia coletiva e o processo de lobotomização em curso na sociedade brasileira, já se estava mais próximo do conceito de happening e de performance, em que a relação com o público era intensificada e uma grande margem da encenação era deixada ao acaso. O teatro, ali, já era Te-ato, como o grupo passou a pregar. [...] O texto, ou roteiro, de Gracias Señor [...] revela uma estrutura mais rigorosa do que se poderia supor em circunstâncias de criação tão abertas. Na verdade, era uma colagem de textos de Nietzsche (Assim Falou Zaratrusta), Shakespeare (Hamlet), Brecht (Mahagony) e Oswald de Andrade (Manifesto Antropofágico e Serafim Ponte Grande) estruturados num jogo dramático simples e direto ${ }^{91}$.

Apesar das distinções que havia entre os modos de organização, escolhas temáticas e investigações cênicas dos grupos teatrais que proliferaram nas décadas de 6o e 70, é inegável a produtividade e importância do trabalho realizado por eles, tanto no Brasil, como no mundo. No entanto, a partir da década de 8o, com o fim da ditadura militar no país e a conseqüente alteração da conjuntura política brasileira, as condições de produção no teatro também se alteraram e assistiu-se à "morte" - ou, pelo menos, à atrofia - da maioria dos grupos teatrais, com honrosas exceções, como, por exemplo, o próprio Teatro Oficina - hoje chamado Oficina Uzyna Uzona - a Tribo de Atuadores Ói Nóis Aqui Traveiz (fundada em 1978, em Porto Alegre) e o Grupo Galpão (criado em 1982, em Belo Horizonte) que, como modelos de grupos estáveis, sobrevivem até hoje. Além disso, assistiu-se, também, ao desenvolvimento de uma encenação autoral, na qual a criação cênica é marcada pela concepção do encenador, ou seja, pela produção de uma escritura teatral autônoma em relação ao texto dramático. Em uma encenação autoral, afirma Sílvia Fernandes ${ }^{92}$, o encenador é responsável não somente pela concepção, mas também pela direção e roteirização do espetáculo. Nesse sentido, é possível pensar o trabalho autoral de encenação, na esteira de José Da Costa, como uma criação cênico-dramatúrgica conjugada.

\footnotetext{
${ }^{91}$ RAMOS, Luiz Fernando. Gracías Portugal. Texto fornecido por Sílvia Fernandes (s/d).

$9^{2}$ FERNANDES, Sílvia. O discurso cênico da Companhia dos Atores IN: FERNANDES, Sílvia. Teatralidades Contemporâneas. São Paulo: Perspectiva, 2010, p. 132.
} 
A noção de criação cênico-dramatúrgica conjugada se refere ao campo do teatro contemporâneo em que a dramaturgia é construída como script (ou roteiro); muitas vezes como teatralização de textos de outros gêneros literários e discursivos (narrativas de ficção, cartas, diários, relatos de viagem etc.) e se produz em conexão direta com as necessidades, demandas e características específicas de projetos cênicos particulares ${ }^{93}$.

Posso citar como exemplos de criações cênico-dramatúrgicas conjugadas, algumas importantes montagens desse período, como os espetáculos encenados por Gerald Thomas (Carmem com Filtro, Electra com Creta, Quartett), Bia Lessa (Ensaio no 1: a tragédia brasileira, Orlando) e Antunes Filho (Macunaíma, Gilgamesh, Nova Velha História), além daqueles dirigidos por Renato Cohen, Ulisses Cruz e outros. O desenvolvimento de uma escrita cênica autoral - que introduziu, no país, "um movimento que, há pelo menos uma década, reunia encenadores norte-americanos [...] e europeus ${ }^{94 "}$ - vai marcar, segundo Baumgärtel ${ }^{95}$, uma profunda "reorientação estética" no campo da criação teatral brasileira. Reorientação que acabou por influenciar, de maneira significativa, a formação artística e profissional dos próprios grupos de teatro e de seus integrantes, pois, muitas vezes, os encenadores assumiram, na relação com essas agrupações, uma função pedagógica de mestres, cumprindo como é o caso de Antunes Filho, em relação ao CPT - a tradição dos famosos sistemas ou métodos de atuação, como os de Stanislávski, Meierhold ou Grotóvski. Nesse sentido, é possível afirmar que esses encenadores não só orientaram o treinamento atoral dos grupos, principalmente daqueles compostos, de maneira predominante, por atores, como também, em profunda correlação com esse primeiro aspecto, acabaram determinando a configuração estética de muitos dos espetáculos produzidos no contexto grupal, como é o caso de Gabriel Villela que, com o Grupo Galpão, montou os

93 DA COSTA FILHO, José. Teatro brasileiro contemporâneo: um estudo da escritura cênicodramatúrgica atual. Tese (Doutorado em Literatura Comparada) - Instituto de Letras da UERJ, 2003, p. 13 .

${ }^{94}$ FERNANDES, 2010: 132.

95 BAUMGÄRTEL, Stephan A. Em busca de uma teatralidade textual performativa na sombra da globalização: reflexões sobre a situação da dramaturgia brasileira no fim dos anos 80 . S/R (artigo inédito). 
espetáculos Romeu e Julieta e Rua da Amargura, cuja estética barroca evidencia a marca forte do encenador.

Em relação à dramaturgia brasileira, Baumgärtel ${ }^{96}$ afirma que, com o fim da ditadura e a conseqüente abertura política e econômica do Brasil, no final dos anos 8o, tornou-se patente que havia uma crise em curso no país. Segundo ele, como a entrada da sociedade brasileira, no início dos anos 9o, "na realidade da economia e da cultura globalizada", ficou evidente que "a estética tradicional da militância, pautada num estilo hegemonicamente dramático, se mostrava incapaz de expressar criticamente as novas questões sociais e angústias pessoais" do público de teatro. Ou seja, pode-se afirmar que - embora houvesse vestígios de experimentações de uma linguagem não dramática ainda nos anos 80 - houve pouco avanço no sentido de uma investigação textual de elementos lingüísticos que pudessem dar conta da complexidade das relações sociais contemporâneas, ainda que a cena teatral (mais que o texto) já viesse, claramente, desenvolvendo escritas cênicas não-referenciais, não lineares e fragmentadas.

Para Baumgärtel, as tentativas de abertura do modelo dramático - no âmbito da dramaturgia brasileira desse período - para outras formas de escrita dramatúrgica que estivessem para "além do drama ou excluídas tradicionalmente do cânone formal" dramático corresponderam, na maior parte das vezes, ao modelo que Szondi descreve, em sua análise da dramaturgia moderna, como tentativas de "salvar o drama". Isso significa dizer que, embora os dramaturgos buscassem incorporar à sua estruturação poética, elementos formais que escapassem de uma estética ilusionista - como aqueles "provenientes do realismo fantástico, do surrealismo, da história em quadrinhos e dos seriados de TV" - os textos, ainda que não fossem mais "rigorosos", correspondiam, do mesmo modo, a uma estética própria do realismo dramático - forma predominante, até então, da dramaturgia brasileira - mesmo que esse não fosse mais capaz de discutir “as forças formadoras da realidade social e da percepção individual desta”.

Para Baumgärtel, essa crise da dramaturgia teria raízes não só em uma possível "hegemonia dos meios audiovisuais" - principalmente da televisão que, segundo ele, poderia propiciar a formação, ou pelo menos a manutenção, de um público

\footnotetext{
${ }^{96}$ BAUMGÄRTEL, op. cit. Todas as referências seguintes a Baumgärtel são ao mesmo artigo do autor que, sendo inédito, não possui referências de data, local de publicação ou páginas.
} 
"dramático" - mas também em aspectos concernentes às relações produtivas do teatro, sendo os principais motivos, segundo ele, tanto a presença de um "modelo teatral" pautado no "cena-centrismo das vanguardas européias e anglo-americanas" - isto é, pautado na concepção autoral dos encenadores - quanto a "impossibilidade econômica de se viver de uma pesquisa dramatúrgica estritamente teatral" e o "surgimento do teatro de grupo que muitas vezes eliminou a figura do dramaturgo individual". No entanto, como Baumgärtel mesmo salienta, a partir de meados dos anos 90, as pesquisas em torno do processo colaborativo vão re-introduzir, como elemento presente e necessário, o dramaturgo no processo de criação do espetáculo, "levando o grupo a investigações de ordem dramatúrgica” que buscavam, muitas vezes, a construção de obras teatrais que pudessem dialogar com o horizonte de expectativas do público de teatro no Brasil, ao considerar, como afirma Luiz Alberto de Abreu, o fenômeno teatral a partir da relação entre o público e o espetáculo.

Aparentemente situar o fenômeno teatral na relação efêmera do espetáculo com o público é uma obviedade. No entanto, essa obviedade produz profundas mudanças. De um lado recoloca o público como elemento importante a ser levado em conta no processo de criação. De outro, afasta a ilusão narcisista de que toda complexidade do fenômeno teatral possa ser reduzida a um único artista [...].

A re-introdução do público como valor a ser considerado num processo de criação artística é assunto complexo e que pede reflexão maior que não cabe no momento. Por ora, basta levantar que o público, em geral, não tem sido incluído como elemento fundamental nas discussões estéticas. [...] No entanto, o público é o elemento que traz ao artista não só o pulso da contemporaneidade como é o fio que o conduz ao universo de sua própria cultura ${ }^{97}$.

É a partir das críticas feitas às práticas anteriores - tanto à criação coletiva, no sentido de sua (in)eficácia estética, quanto à encenação autoral, no sentido de um domínio absoluto dos encenadores sobre a cena - que, em meados dos anos 90, foram retomadas, no Brasil, as práticas compartilhadas de criação. Retomada que foi

\footnotetext{
${ }^{97}$ ABREU, Luiz Alberto de. Processo Colaborativo: relato e reflexões sobre uma experiência de criação. CADERNOS DA ELT, Santo André, v. 1, n. o, mar. 2003, p. 38.
} 
caracterizada, no entanto, pela necessidade não só de autonomia, mas, principalmente, da garantia de um espaço de proposição relacionado à especificidade de cada função artística ligada à cena, inclusive da dramaturgia. Começava a se aprofundar a pesquisa em torno da criação de uma obra teatral por meio do processo colaborativo. Parecia haver o desejo, em contraposição a um grande desenvolvimento, a partir dos anos 8o, do papel do encenador, de uma autonomia - e de uma autoria - criativa por parte das outras funções vinculadas à cena. Porque se a noção de uma criação compartilhada implica em uma desierarquização entre as funções artísticas, isso significa dizer que também os espaços de proposição e decisão são horizontalizados, fazendo com que a autoria da obra resultante seja, em decorrência disso, compartilhada.

No que tange às críticas feitas em relação à criação coletiva, pode-se dizer que uma boa parte dos estudos atuais centrados sobre o processo colaborativo ${ }^{98}$ - ao propor um modelo geral para a criação coletiva dos anos 6o e 70, a fim de distingui-la da prática hodierna - parece deixar de considerar que, em muitos grupos e países, principalmente na América Latina, ela não foi abandonada como prática produtiva e que seu exercício constante parece ter levado a uma superação de suas próprias deficiências.

Ao se considerar o material teórico produzido por esses coletivos teatrais, é possível perceber que a descrição da criação coletiva, pensada como método, não se difere, de maneira substancial, do chamado processo colaborativo, pois, inúmeras vezes, no processo de criação coletiva, havia a necessidade de que pessoas se ocupassem de tarefas específicas relacionadas à criação do espetáculo, tais como organização de ensaios, improvisos e definições relativas à própria cena (função que muitos grupos denominaram como “animador" e não "diretor", por questões ideológicas); ou da costura cênica, dando coerência ao material coletado por todos

\footnotetext{
${ }_{98}^{8}$ Posso citar como exemplo, os estudos de Adélia Nicolete Abreu e de Luiz Alberto de Abreu, nos quais há uma distinção clara entre os dois modos de criação, pautada, principalmente, na especificidade artística presente no processo colaborativo. Além disso, eles tecem uma forte crítica em relação à qualidade estética da produção teatral resultante da criação coletiva. Também Antônio Araújo, em sua dissertação de mestrado (2002), vai discutir esses mesmos aspectos, sob uma perspectiva bastante semelhante. Já em sua tese de doutorado (2008), ele relativiza a questão e reconhece não só a importância de muitas obras produzidas em um sistema de criação coletiva, como também o fato de que, em diversos processos de criação coletiva, vivenciados tanto no Brasil como na América Latina de um modo geral, muitas vezes havia a presença marcante do diretor (ainda que o dramaturgo não se constituísse, de fato, como uma função específica), aproximando a prática da criação coletiva do processo colaborativo.
} 
(chamado "dramaturgista" ou "conselheiro literário", pelas mesmas razões). É perceptível que, muitos dos indivíduos que se uniam em grupos com a proposta de desenvolverem uma criação coletiva, chegaram, com o passar dos anos, perto do que, atualmente, é definida como prática colaborativa, ao caminhar em direção a uma autoorganização, mesmo que fosse sem uma sistematização de seus processos de trabalho. Santiago García, diretor do La Candelaria, é um deles, começando até mesmo a esboçar, a partir da elaboração de uma metodologia, uma definição de funções artísticas específicas no interior da prática criativa.

Segundo García ${ }^{99}$, ao começar um processo de criação coletiva, é necessário ter motivação e essa não tem que vir necessariamente do diretor. Espera-se que a proposta venha da "realidade circundante", daí a importância de se ter conhecimento acerca dos acontecimentos sócio-políticos de seu país. A etapa seguinte é a pesquisa. Dividido em equipes, o grupo recolhe todo material encontrado relacionado ao tema: reportagens, fotos, filmes, músicas, poesia, livros. Posteriormente, se passa às improvisações, visto estar o grupo cheio de informações. Ainda segundo ele, não há uma forma ou método a ser seguido rigidamente, pois cada "obra exige uma técnica, ou uma forma diferente de fazer as improvisações ${ }^{100 ”}$. Numa quarta etapa, busca-se a definição de um argumento que virá a ser uma primeira hipótese de estrutura - e os detalhes do tema escolhido vão definindo suas linhas gerais.

Evidentemente, esses passos variam de um trabalho para outro, ou seja, a ordem não é necessariamente essa. Segundo García, aqui já se trata das linhas gerais, ou melhor, argumentais. Essas linhas argumentais começam a ser definidas através de uma série de improvisações, depois de conhecidas as linhas temáticas e expressas numa primeira proposta estrutural. Depois vêm a montagem e o texto. Quanto à montagem, os elementos necessários vão sendo elaborados, paralelamente, ao longo do trabalho. Esses elementos podem ser músicas, canções e corais, vestuário, cenografia etc. Quanto ao texto, este é escrito pela equipe encarregada da dramaturgia (que pode contar com a colaboração de poetas ou escritores). Ainda segundo ele, essa equipe vai recolhendo os diálogos que aparecem nos ensaios e improvisações e, quando escritos, os apresenta ao grupo para serem discutidos e ensaiados.

\footnotetext{
${ }^{99}$ GARCÍA, Santiago. Teoria e Prática do Teatro. São Paulo: Editora Hucitec, 1988, pp. 27-39.

${ }^{100}$ Ibidem: 27.
} 
Todos os aspectos levantados por García evidenciam que a divisão de funções ${ }^{101}$ - considerada uma das maiores diferenças entre os dois processos - resulta, na criação coletiva, de uma constante prática e reflexão no interior dos próprios coletivos teatrais que a praticam. E mesmo em um comentário crítico de Antônio Araújo sobre a prática exercida pelos grupos brasileiros nos anos 6o e 70, é possível perceber que o caminho em direção a uma organização funcional é inerente aos processos coletivos; pois, neles, "determinados indivíduos assumiam, veladamente ou com pouca consciência do fato, as áreas de criação que se sentiam mais a vontade, fosse por algum talento ou facilidade específica, fosse pelo prazer advindo daí ${ }^{102 ”}$.

Para Sílvia Fernandes, no entanto, embora Santiago García designe como criação coletiva o modo de produção teatral do La Candelaria, este seria, de seu ponto de vista, um modo de criação estritamente colaborativo, justamente em função da presença marcante do encenador e do exercício da dramaturgia por uma equipe especializada. Nesse sentido, ela afirma que o processo colaborativo "tem semelhanças com a criação coletiva, mas não se confunde com ela ${ }^{103 ”}$. Segundo a pesquisadora, mesmo que o processo colaborativo, como conceito, se filie a essa forma de criação cênica, ele guarda, em relação a ela, algumas diferenças fundamentais como, por exemplo, a garantia e especificidade de cada função artística. Para Sílvia Fernandes, as distinções entre os dois processos são evidenciadas, sobretudo, pelas experiências brasileiras de criação coletiva - mais do que pelas experiências colombianas, nas quais ambos os modos de criação se confundem - como é o caso daquelas realizadas pelos

\footnotetext{
${ }^{101}$ Mesmo em termos de metodologia de criação, pode-se dizer que existem grandes semelhanças entre os dois processos de criação compartilhada da cena. Antônio Araújo (SILVA, 2002: 106) divide o processo colaborativo em três grandes etapas (ou momentos):

1. Etapa de livre exploração e investigação: em que as questões centrais do projeto são estudadas, improvisadas e experimentadas, com o objetivo de mapear o campo da pesquisa, levando à identificação de parâmetros e possibilidades. Aqui é onde se deu, fundamentalmente, o levantamento do material cênico;

2. Etapa de estruturação dramatúrgica: em que ocorre a seleção do que foi levantado, visando à criação de partituras de ação, esboços de cena e, em seguida, à roteirização propriamente dita. Essa etapa pressupõe o estabelecimento de, pelo menos, uma primeira versão do texto;

3. Etapa de estruturação do espetáculo e de aprofundamento interpretativo: em que a escrita da cena passa a ocupar o centro das preocupações, tanto no que diz respeito às marcações, espaço cênico, tratamento visual, sonoro, etc., quanto ao aprimoramento do trabalho do ator. $\mathrm{O}$ aspecto dramatúrgico continua a ser desenvolvido aqui, enquanto lapidação e acabamento, porém como um foco secundário.

${ }^{102}$ SILVA, 2002: 101.

${ }^{103}$ FERNANDES, Sílvia. O lugar da Vertigem IN: ARAÚJO et alii. Trilogia bíblica. São Paulo: Publifolha, 2002, p. 37.
} 
grupos teatrais nos anos 70, mas, também, das experiências contemporâneas, como as vivenciadas pela Tribo de Atuadores Ói Nóis Aqui Traveiz, de Porto Alegre e pela Luna Lunera, companhia de teatro de Belo Horizonte.

A Luna Lunera, por exemplo, embora já tenha realizado montagens a partir tanto de textos pré-concebidos e de uma concepção de encenação prévia - como em seu primeiro espetáculo, Perdoa-me por me traíres, com direção de Kalluh Araújo como também a partir de práticas colaborativas - caso de Nessa data querida, montagem resultante de sua participação no projeto Cena $3 \times 4$ - evidencia a opção por um sistema de criação coletiva na construção da maioria de seus trabalhos, posteriores à experiência no projeto Cena 3x4. É exemplar dessa opção, o espetáculo Aqueles Dois, cujo tecido dramatúrgico é marcado, fortemente, por traços oriundos do processo de criação, principalmente por aqueles concernentes a um trabalho especificamente atoral, tais como a opção de se iniciar o espetáculo com uma prática de contato improvisação que, aos poucos, se transforma em cena ou as quebras da linha ficcional por meio da introdução do pensamento do ator, confidências e relações que ele guarda com a personagem ou com o conto de origem e seu autor: Aqueles Dois, de Caio Fernando Abreu.

Em Aqueles Dois, da Luna Lunera, os atores assinam tanto a dramaturgia quanto a encenação, sendo responsáveis por todas as decisões estéticas, sejam elas de ordem textual ou cênica. Tal fato é evidenciado pela ficha técnica do espetáculo, na qual constam, como diretores-criadores, os quatro atores que estão em cena - Marcelo Souza e Silva, Cláudio Dias, Odilon Esteves e Rômulo Braga - e ainda o relator do processo e provocador externo à cena, José Walter Albinati. O núcleo de cinco criadores é responsável, ainda, pela criação do cenário e do figurino, pelo treinamento corporal e vocal e pela produção do espetáculo. São eles que relatam o processo:

Em maio de 2007, numa iniciativa informal, sem recursos, a Cia. propôs-se estabelecer internamente um grupo de estudos sobre Contato Improvisação e o Método das Ações Físicas e Verbais, tendo respectivamente Cláudio Dias e Odilon Esteves como mediadores. [...] Na prática, acabou-se por deslocar o mote inicial de estudos para um outro propósito latente: investir num exercício coletivo de direção e dramaturgia a ser desenvolvido pelos atores do grupo. Ainda nesta fase, decidiu-se aplicar as primeiras vivências da pesquisa 
tendo por base alguns textos aleatórios. Focou-se posteriormente na exploração do conto AQUELES DOIS, de Caio Fernando Abreu, descobrindo nele suas instigantes qualidades épico-dramáticas e uma inspiração para potencial montagem.

Organizou-se um cronograma de direção conduzida a cada semana por um dos quatro atores envolvidos no processo nesta fase, a saber: Marcelo Souza e Silva, Cláudio Dias, Odilon Esteves e José Walter Albinati, tendo este último optado por dedicar-se exclusivamente ao núcleo de direção e dramaturgia, compartilhadas junto aos demais, o que gerou o convite para que Rômulo Braga (Cia. Lúdica) viesse compor o quarteto de atores que se verá em cena.

Esse coletivo partiu de improvisações e imersões na obra de Caio, propôs, sobrepôs e experimentou roteiros e, literalmente "a dez mãos", assina a criação do espetáculo, que conta de fato com a contribuição do público interessado, presente a cada sessão aberta do Observatório de Criação, cujos feedbacks têm funcionado como autênticos norteadores e ainda se renovarão ao longo da temporada ${ }^{104}$.

Assim como Sílvia Fernandes, Rosyane Trotta também afirma a distinção entre os dois processos de criação compartilhada a partir do estudo que realizou, em sua tese de doutoramento ${ }^{105}$, a cerca das práticas de criação de alguns grupos de teatro, entre eles a Tribo dos Atuadores Ói Nóis Aqui Traveiz. Segundo ela (TROTTA, 2008: 87), embora em ambos os processos o texto não tenha uma existência anterior ao projeto do grupo e sua criação se dê à medida que o espetáculo vai sendo elaborado, na criação coletiva a criação textual - bem como a concepção e produção do espetáculo - fica a cargo dos atores e do diretor, ou seja, na criação coletiva não somente as escolhas relacionadas ao texto cabem a eles, como, por conseqüência, o texto acaba se configurando como uma instância indissociável da cena, uma vez que ele dela emerge. Já no processo colaborativo, os atores participam da construção do espetáculo, mas a criação textual fica a cargo do dramaturgo que, como função específica e especializada, é responsável pelas escolhas relacionadas ao texto. Nesse caso, como afirma Rosyane Trotta, o texto "é construído em diálogo com a cena", cabendo ao encenador e ao dramaturgo estabelecer o modo como se opera esse diálogo.

\footnotetext{
${ }^{104}$ Disponível em www.cialunalunera.blogspot.com (acessado em 13/02/2011).

${ }^{105}$ TROTTA, Rosyane. A autoria coletiva no processo de criação teatral. Tese (Doutorado em Teatro)

- Centro de Letras e Artes da UNIRIO, 2008.
} 
Para a pesquisadora, existe ainda uma importante distinção entre os dois processos: enquanto que na criação coletiva, “o ponto de partida para a experimentação cênica é a proposta criada pelo grupo", no processo colaborativo “o ponto de partida para a experimentação cênica e para a criação do texto é o projeto apresentado pelo encenador". Isso significa dizer que, enquanto na criação coletiva "o grupo se forma por afinidade entre os participantes e as funções se estabelecem no processo", no processo de criação colaborativa, segundo ela (TROTTA, 2008: 87), o projeto está centrado na figura do encenador. Ou seja, nesse caso o "grupo se forma por afinidade com o projeto", sendo cada integrante da equipe de criação "convidado pelo diretor a ocupar determinada função”. Dessa perspectiva, não somente os dois processos se distinguem quanto ao seu modo de criação, como também os campos autorais são diversos. Para Rosyane Trotta, na criação coletiva o campo autoral é coletivo, enquanto que no processo colaborativo, esse campo é plural.

Para o estudo do processo colaborativo, o Teatro da Vertigem e a Escola Livre de Santo André ${ }^{106}$ são referências importantes. Antônio Araújo, diretor do Teatro da Vertigem, considera, assim como Sílvia Fernandes, que "o elemento função é o aspecto axial definidor do processo colaborativo ${ }^{107}$ ". Para ele, "se a criação coletiva permitia, a cada membro do grupo, a máxima utilização de sua capacidade criadora na associação concomitante de diferentes áreas de criação ${ }^{108 "}$, no processo colaborativo, ao contrário, essa capacidade criadora vai ser direcionada para uma determinada função ou atributo, uma vez que a criação colaborativa pressupõe que "todos os integrantes, a partir de suas funções artísticas específicas, têm igual espaço propositivo, sem qualquer espécie de hierarquias, produzindo uma obra cuja autoria é compartilhada por todos ${ }^{109 ”}$.

Se nas criações coletivas o ator ganha, muitas vezes, o estatuto de centro gerador de onde emerge a criação cênica, é inegável, no entanto, que ele - como

\footnotetext{
${ }^{106}$ A partir dos anos 90, criadores e pensadores importantes da cena contemporânea paulista, como Antônio Araújo, Luiz Alberto de Abreu, Tiche Vianna, Luiz Fernando Ramos e Francisco Medeiros, entre outros, vão desenvolver, no âmbito da Escola Livre de Teatro de Santo André, importantes experiências de aprendizagem e criação colaborativa. Essas experiências vão influenciar o pensamento pedagógico de outros centros formadores, como o Galpão Cine Horto, de Belo Horizonte e a Faculdade Dulcina de Moraes, em Brasília, e difundir a pesquisa em torno do processo colaborativo em diversos grupos do cenário nacional, como o próprio Grupo Galpão, a Maldita Cia. e o Grupo Teatro Invertido, de Belo Horizonte, e o Teatro do Concreto, de Brasília.

${ }^{107}$ SILVA, 2008: 179 .

${ }^{108}$ Ibidem.

${ }^{109}$ SILVA, 2002: 101 (grifos meus).
} 
veículo e executante das propostas de todos os criadores (inclusive dele mesmo) - tem seu olhar intrínseco à cena. Desse modo, parece ser necessário buscar, no interior mesmo da criação, a construção de um olhar obsceno. Não no sentido que essa palavra, em oposição à noção de "cena” - skené, o "lugar onde ocorre a ação" - vai assumir: de um lugar social que, estabelecido em termos de práticas discursivas, é fora da cena, ou seja, aquele diante do qual se apresenta a obra teatral: o lugar do espectador. Aqui, “obsceno", embora possa ser uma atitude do espectador, adquire a conotação de uma posição privilegiada que vai, ao mesmo tempo, ser externa à cena e interna à criação e que possibilita o exercício de uma "projeção escaldante de tudo que pode ser extraído [...] de um gesto, uma palavra, um som, uma música e da combinação entre eles. Essa projeção ativa - que só pode ser feita em cena e suas conseqüências encontradas diante da cena e na cena ${ }^{110 " ~-~ p a r e c e ~ s e r, ~ p o r ~ e x c e l e ̂ n c i a, ~ t a n t o ~ o ~ c a m p o ~ d o ~ e n c e n a d o r ~ c o m o ~ o ~}$ campo do dramaturgo, dentro de um processo colaborativo de criação. Partindo da premissa, levantada por Antônio Araújo, de que a definição de funções é o aspecto axial definidor desse modo de criação (ainda que não seja um elemento, como procurei demonstrar, que vá distingui-lo, rigorosamente, da criação coletiva), gostaria de pensar, agora, a especificidade artística dessas duas funções obscenas, ou seja, perceber quais seriam os limites e matérias próprias da encenação e da dramaturgia no âmbito da criação colaborativa.

No que tange ao trabalho de dramaturgia, Antônio Araújo afirma que a presença do dramaturgo na sala de ensaio vai ser, justamente, um dos aspectos mais importantes do modo de organização das relações entre os criadores dentro do processo colaborativo. Tradicionalmente território dos atores e do diretor (eventualmente dos outros artistas mais diretamente vinculados à materialidade da cena, como cenógrafos e iluminadores), a sala de ensaio e o espaço de improviso passam a fazer parte do universo do dramaturgo, antes restrito ao escritório ou gabinete. Já em sua dissertação de mestrado, Antônio Araújo discutia a participação ativa do dramaturgo no processo de criação.

Acreditamos num dramaturgo presente no corpo-a-corpo da sala de ensaio, discutindo não apenas o arcabouço estrutural ou a escolha das

\footnotetext{
${ }^{110}$ ARTAUD, 1999: 81.
} 
palavras, mas também a estruturação cênica daquele material. Nesse sentido, pensamos numa dramaturgia como uma escrita da cena e não como escrita literária, aproximando-a da precariedade e efemeridade da linguagem teatral, apesar do suporte do papel no qual ela se inscreve. [...] Ao invés de um escritor de gabinete, exilado da ação e do corpo do ator, queremos um dramaturgo da sala de ensaio, parceiro vivo e presente dos intérpretes e do diretor (SILVA, 2002: 103).

Nesse sentido, pode-se afirmar que uma dramaturgia em processo pressupõe uma colaboração direta entre texto e cena. Para Antônio Araújo (SILVA, 2002: 103), a dramaturgia, privada de sua "aura de eternidade", vai se evaporar "no suor da cena, no hic et nunc do fenômeno teatral" ou, em outras palavras, o processo colaborativo vai garantir ao dramaturgo um espaço de experimentação textual, de improvisação dramatúrgica. Ainda segundo ele, a dramaturgia, destituída da idéia de texto fixador ou imutável, não é mais vista como o objeto de onde emana a encenação, mas como um elemento em constante transformação, e o dramaturgo, com "um estatuto de precariedade e provisoriedade igual ao dos outros criadores da cena”, acaba por se tornar tão dependente dos ensaios para o desenvolvimento de sua obra quanto o ator e o diretor (SILVA, 2002: 104). Em razão disso, caberá ao dramaturgo trazer propostas concretas para o desenvolvimento do texto-espetáculo, sejam elas imagéticas, verbais, gestuais ou cênicas, bem como dialogar com o material produzido nos ensaios, em exercícios e improvisos ${ }^{111}$.

Quanto ao trabalho de encenação, é possível constatar que, mesmo em espetáculos produzidos em processo (work in process), a idéia de uma posição desierarquizada do encenador - principalmente no que tange à autoria da obra, ou seja, à determinação das escolhas fundamentais de sentido e articulação cênica - pode ser não só mal vista, como ainda não ser aceita por muitos. O encenador Renato Cohen $^{112}$, por exemplo, sustenta uma visão mais próxima da posição hierárquica tradicional - na qual o encenador guarda a posição de autoridade máxima da cena,

\footnotetext{
${ }^{111}$ De certo modo, isso cabe a todos os criadores da cena. Ainda que, para Antônio Araújo, a tríade básica da criação colaborativa seja composta por atores, diretor e dramaturgo, ele considera que todos os artistas envolvidos na criação de uma obra, "apesar de comprometidos com determinado aspecto da criação, precisariam integrar-se numa discussão de caráter mais generalizante".

${ }^{112}$ COHEN, Renato. Work in progress na cena contemporânea: criação, encenação e recepção. São Paulo: Perspectiva, 2004b.
} 
responsável pela concepção e criação total da obra de arte - do que da perspectiva "horizontal" presente no processo colaborativo, pois, para ele, a cena contemporânea privilegia “o criador (em presença), sua voz autoral, em que se acumulam as funções de direção, criação da textualização de processo e linkage da mise-en-scène ${ }^{113 ”}$. Ele afirma ainda:

Ao encenador-orquestrador da polifonia cênica, na operação dos fluxos intersemióticos, de partituras de textos, imagem, corporeidades e suportes - e não ao dramaturgo - cabe a guia da cena contemporânea. Encarna, nesse sentido, a função de "homem total do teatro" preconizada pelo teatralista Edward Gordon Craig ${ }^{114}$.

Em um processo de criação colaborativa, no entanto, o encenador perde a posição de autoridade que lhe é outorgada nos processos tradicionais e seria possível questionar se, junto com a posição de autoridade, ele perderia também sua função. Evidentemente, o encenador que escolhe trabalhar em um sistema de criação colaborativa não busca mais "uma escrita cênica autoral, de grafia inconfundível" (FERNANDES, 2002: 35). Nesse sentido, pode-se afirmar, na esteira de Antônio Araújo, que o encenador-em-processo escolhe esse modo de criação - no qual ele não funciona mais como eixo central na concepção dos espetáculos e a criação se dá a partir de um projeto cênico coletivo, não de um projeto de encenação - como parte de sua poética cênica, uma poética marcada pelo risco e pela alteridade. Essa dinâmica processual, como observa Antonio Araújo, do mesmo modo que define a poética cênica, ou seja, o trabalho do encenador, vai definir, também, todas as outras esferas de criação dentro do processo colaborativo:

A encenação-em-processo é uma encenação negociada, ou, se quisermos, é uma encenação de alteridades.

E não é somente ela que se encontra em desenvolvimento: o imperativo processual impregna e mobiliza tudo. Temos, portanto, uma dramaturgia em processo, uma interpretação em processo, uma iluminação em processo, e assim por diante. No caso específico do processo colaborativo, num âmbito

\footnotetext{
${ }^{113}$ COHEN, 2004b: XXVIII.

${ }^{114}$ Ibidem.
} 
mais amplo do que aquele delineado por Cohen, não se trata apenas da estruturação de um "roteiro" ou "storyboard". Há o objetivo de se constituir uma dramaturgia textual. Porém, a sua formulação pode passar longe dos modelos dramáticos convencionais e até mesmo incorporar procedimentos artísticos os mais diferenciados (SILVA, 2008: 191).

A encenação em processo (bem como a dramaturgia) apresentaria, na perspectiva de Antônio Araújo, uma estrutura móvel, instável, sujeita às ondas de turbulência geradas pelo conflito entre as diferentes processualidades. Essas turbulências vão afetar as formalizações cênicas e textuais de modo direto e simultâneo, sem que, em razão disso, elas sejam enfraquecidas. Segundo ele (SILVA, 2008:191), os dois pólos - encenação e dramaturgia - não vão se desestruturar - pois não se submetem um ao outro e, nesse sentido, não se anulam nem se dissolvem mas, ao contrário, vão se contaminar e se fortalecer, adquirindo "uma estrutura porosa, permeável e flexível”. Em razão disso, a encenação, por já ter inscrito no texto sua "poética espetacular", não "desconstrói ou relê o texto ao seu bel prazer". Do mesmo modo, a dramaturgia, "em processo de encenação", já terá, ela também, “inoculado" sua "textualidade" ou teatralidade no discurso cênico (SILVA, 2008: 191).

Como funções que guardam uma posição externa à cena e que são responsáveis por níveis estruturais em relação à criação da obra espetacular, encenação e dramaturgia acabam por ter, no âmbito da criação colaborativa, seus limites borrados, e, talvez, não seja possível falar de uma dramaturgia espetacular sem confundir seu nível de atuação com o de uma poética da cena, própria do trabalho do encenador. Para Antônio Araújo, a tensão existente entre a dramaturgia e a encenação durante o processo de criação de uma obra é uma de suas principais linhas de força, justamente porque operam em conjunto, sem que uma esteja a serviço da outra. Segundo ele, o dramaturgo também cria, de certo modo, a encenação, bem como o encenador tem participação na criação do texto.

Cena e texto estão juntos, dialogam, e, de certa forma, sem perder sua autonomia ou campo, estão marcados e contaminados um pelo outro. No limite, ambos abdicam do seu caráter processual em si, para adquirirem uma dinâmica processual inter-relacional. Em outras palavras, trata-se de uma 
“dramaturgia em processo de encenação" e de uma "encenação em processo de dramaturgização" (SILVA, 2008: 191).

Dessa perspectiva, buscar uma demarcação estrita dos territórios de autoria, no interior desses processos, é, de certo modo, uma atitude contraditória: é mais pertinente desfiar, das tramas do tecido dramatúrgico, as possíveis marcas deixadas por um percurso processual e pela proximidade da poética espetacular. Desse ponto de vista, é possível pensar em um conceito de dramaturgia que, decorrente de um processo de criação compartilhado, não somente privilegie a autonomia das diversas vozes criadoras - dos seus gestos de enunciação, das matérias por meio das quais elas operam - mas garanta, também, a marca desse embate na superfície do texto mesmo: uma dramaturgia polifônica.

\subsection{Dramaturgias polifônicas, poéticas do espaço}

Embora o conceito de polifonia - desenvolvido por Bakhtin acerca da obra de Dostoiévski - se debruce, especificamente, sobre a produção de um único autor, ele é bastante profícuo - em razão de suas características específicas - para se pensar não somente as relações criativas que ocorrem no âmbito dos processos compartilhados de criação, mas, principalmente, a tessitura resultante desses processos. Antônio Araújo também aborda, em sua tese de doutoramento, o conceito de polifonia, mas em uma perspectiva diversa, pois centrada na definição conceitual do processo colaborativo e das relações entre os criadores. Aqui, o meu desejo é buscar para a dramaturgia produzida em um processo de criação colaborativa, um conceito que abarque suas características formais, decorrentes, do meu ponto de vista, desse modo de produção no qual as matérias cênicas diversas estão em permanente fricção e diálogo.

Segundo Bakhtin (2008: 5), a polifonia é caracterizada, precisamente, pela "multiplicidade de consciências eqüipolentes e seus mundos que se combinam numa unidade de acontecimento, mantendo a sua imiscibilidade". Desse modo, uma tessitura polifônica não se caracteriza por uma idéia de progressão ou de acumulação - 
isto é, ela não é caracterizada por aquilo que Bakhtin denominou, em relação à visão artística de Goethe, como série em formação ${ }^{115}$ - mas opera, basicamente, por meio de suas categorias fundamentais, a coexistência e a interação (BAKHTIN, 2008: 31). Isso significa dizer que, no texto polifônico, não só há uma multiplicidade de vozes em diálogo constante, como também, em conseqüência desse dialogismo, há ainda uma simultaneidade de planos - uma multiplanaridade - e uma heterogeneidade de matérias das quais esse tecido é constituído (BAKHTIN, 2008: 16). Assim, embora a obra polifônica possa ter, como em Dostoiévski, uma "profunda atração pela forma dramática ${ }^{116 ”, ~ o ~ c o n c e i t o ~ d e ~ p o l i f o n i a ~ e ́ ~ i n c o m p a t i ́ v e l, ~ c o n f o r m e ~ s a l i e n t a d o ~ p e l o ~ t e o ́ r i c o ~}$ russo, com a premissa de um mundo homogêneo, típico da poética do drama, pois este é monologicamente uno. Em outras palavras, a multiplicidade de vozes, planos e matérias resultaria no enfraquecimento da forma dramática.

\footnotetext{
As réplicas do diálogo dramático não subvertem o mundo a ser representado, não o tornam multiplanar; ao contrário, para serem autenticamente dramáticas, elas necessitam da mais monolítica unidade desse mundo. [...] As personagens mantêm afinidade dialógica na perspectiva do autor, diretor, espectador, no fundo preciso de um universo monocomposto. A concepção da ação dramática que soluciona todas as oposições dialógicas é puramente monológica. A verdadeira multiplanaridade destruiria o drama, pois a ação dramática baseada na unidade do mundo, já não poderia relacionar e resolver essa multiplanaridade (BAKHTIN, 2008: 18).
}

Diferentemente da forma dramática - que, por meio da progressão de uma ação, ocorre na dimensão temporal - a polifonia, segundo Bakhtin, vai ocorrer no espaço e procurar "captar as etapas propriamente ditas em sua simultaneidade, confrontá-las e contrapô-las", pois, na obra polifônica, "interpretar o mundo implica em pensar todos os seus conteúdos como simultâneos e atinar-lhes as inter-relações em um corte temporal ${ }^{117}$ ". Nesse sentido, é possível distinguir o dialogismo característico de uma

\footnotetext{
115 "[Goethe] procura perceber todas as contradições existentes como diferentes etapas de um desenvolvimento uno, tende a ver em cada fenômeno do presente um vestígio do passado, o ápice da atualidade ou uma tendência do futuro; como conseqüência, nada para ele se dispõe num plano extensivo" (BAKHTIN 2008: 31).

${ }^{116}$ BAKHTIN, op. cit., p. 18.

${ }^{117}$ Ibidem: 31. Grifos do autor.
} 
tessitura dramatúrgica polifônica da noção de diálogo que caracteriza a poética do dramático ou mesmo da premissa de que o fenômeno teatral é, por excelência, uma construção coletiva, isto é, da idéia de que o fenômeno teatral poderia ser polifônico simplesmente por ser constituído por uma determinada multiplicidade de elementos materiais, ainda que a resultante cênica desta multiplicidade seja homogênea ou busque a totalização, como na gesamtkustwerk (obra de arte total) preconizada por Wagner. Em uma dramaturgia polifônica, ao contrário, a heterogeneidade dos diversos elementos significantes presentes no tecido dramatúrgico da cena, é resultante de um modo de produção não somente coletivo, mas que deseja o confronto entre as vozes criadoras, garantindo sua imiscibilidade e eqüipolência.

Desse modo, tanto o processo de criação é polifônico como também o serão, como aspectos decorrentes deste primeiro, o discurso cênico produzido e o mundo ficcional plasmado por meio das relações entre os criadores e as matérias heterogêneas que compõem a cena. Dessa perspectiva, é possível afirmar que, em uma dramaturgia polifônica, a relação entre as vozes criadoras - ou entre as matérias significantes do discurso cênico - produz uma inscrição, um rastro desse embate entre vozes na superfície do texto e, até mesmo, na estruturação, por assim dizer, "fabular" da dramaturgia, o que é evidenciado, por exemplo, pelo uso da coralidade. Assim, embora o conceito de polifonia não esteja restrito à produção escrita - pois se refere também ao diálogo que é operado entre as matérias heterogêneas do discurso cênico, fazendo com este se constitua como um tecido multiplanar - um aspecto bastante importante do dialogismo presente nesse conceito é a percepção de que ele vai não somente localizar a dramaturgia polifônica nas fronteiras entre a escrita e a cena, como, em decorrência disso, vai desterritorializá-la.

Nesse sentido, como salienta Sílvia Fernandes ${ }^{118}$, talvez seja arriscado dissociar a escrita da cena, ou a textualidade da teatralidade - como em Barthes, que definia a teatralidade como o teatro menos o texto - uma vez que "a criação conjunta de cena e texto", nos processos contemporâneos de criação colaborativa, "supera a polarização entre as duas instâncias e contribui para a diluição de fronteiras rígidas, abrindo

\footnotetext{
${ }^{118}$ FERNANDES, Sílvia. Teatralidade e textualidade: a relação entre cena e texto em algumas experiências de teatro brasileiro contemporâneo IN: FERNANDES, Sílvia. Teatralidades Contemporâneas. São Paulo, Perspectiva, 2010, pp. 101-111.
} 
espaço a um vasto campo de práticas que subsidia e informa tanto a produção do texto literário quanto do texto cênico" (FERNANDES, 2010: 102). Como ela afirma em relação à experiência do Teatro da Vertigem, cuja "produção de dramaturgias e encenações baseadas em pressupostos construtivos semelhantes [...] explica, ao menos em parte, a inclinação desses textos para a incorporação de alguns paradigmas cênicos", sem dúvida alguma, o texto colaborativo deverá refletir, na apropriação lingüística que faz da matéria cênica, o processo polifônico que o engendrou.

Tendo essa perspectiva como eixo, buscarei, nos dois capítulos que se seguem, perceber, a partir da análise de processos colaborativos vivenciados por grupos teatrais de Belo Horizonte - bem como dos textos-espetáculos nos quais resultaram - em que medida sua dramaturgia, como matéria concebida em um processo colaborativo, vai carregar, entrelaçados em sua trama, não somente os traços/rastros performativos que a proximidade com a cena poderia deixar - jogos de atuação, simultaneidades de ação, corporeidade - mas, ainda, as marcas polifônicas oriundas desse processo, como, por exemplo, a coralidade e o contraponto. Já no último capítulo, a partir da análise do processo de criação de experimentos cênicos desenvolvidos no âmbito da pesquisa realizada pelo Obscena, buscarei abordar de que modo as relações criativas desenvolvidas dentro de uma rede colaborativa de investigação e criação cênica podem gerar outras formas de escrita que, ultrapassando o conceito de polifonia, mergulham na performatividade. 
Eu preciso dessas palavras escrita.

Artur Bispo do Rosário 


\section{Maldita Companhia: em busca de uma dramaturgia polifônica}

\subsection{A gênese: projeto Cena $3 x_{4}$}

Tendo como referência o projeto de formação da Escola Livre de Teatro de Santo André e também o Centro de Demolição e Construção do Espetáculo, experiência capitaneada por Aderbal Freire Filho no Rio de Janeiro, foi criado em 1998, em Belo Horizonte, o Galpão Cine Horto, centro cultural pensado como um espaço de compartilhamento e troca do Grupo Galpão com a comunidade belorizontina e com outros artistas, tanto da cidade como do país. Segundo Chico Pelúcio, ator do grupo e diretor geral do Galpão Cine Horto, o que norteou a sua criação foi a "a busca de uma vivência coletiva, de uma ética e de valores próprios do trabalho de grupo, seja na sala de criação, seja nas tarefas organizacionais ou nas relações com a comunidade”".

Como carro-chefe do centro cultural, o projeto Oficinão ${ }^{2}$ propõe, justamente, uma vivência de grupo para atores profissionais, a partir de um "mergulho" em uma experiência de criação pautada por um tema de pesquisa e que resulta, ao final de um ano de trabalhos, em uma montagem. Após sua primeira edição - que teve como eixo temático a obra de Shakespeare e culminou na montagem da peça Noite de Reis, dirigida por Chico Pelúcio - o Oficinão vai sofrer uma importante alteração: Júlio Maciel, ator do Grupo Galpão responsável pela coordenação da segunda edição e pela direção da futura montagem, resolve convidar Luiz Alberto de Abreu, dramaturgo e professor da Escola Livre de Teatro de Santo André, para organizar uma oficina de dramaturgia que funcionaria como núcleo de criação responsável pela estruturação da dramaturgia original para o tema daquele ano, os 500 anos de Descobrimento do Brasil.

A partir de suas experiências na Escola Livre, Abreu propôs, para fundamentar o trabalho desenvolvido não só pela Oficina de Dramaturgia, mas por toda a equipe

\footnotetext{
${ }^{1}$ PELÚCIO, Chico. O projeto Oficinão do Galpão Cine Horto IN: Cadernos de Dramaturgia do Galpão Cine Horto: oficinão. Belo Horizonte: Argvmentvm, 2009, vol. 1, p. 8.

${ }^{2}$ Atualmente, os principais projetos desenvolvidos no Centro Cultural são, além do Oficinão para Atores, o Festival de Cenas Curtas, o Cena Espetáculo e o Pé na Rua, entre outros.
} 
envolvida no projeto, uma metodologia de criação colaborativa. O processo resultou no espetáculo Caixa Postal 150o, cuja dramaturgia - fragmentada pelos diversos pontos de vista apresentados, pertencentes a personagens anônimos da história brasileira dos séculos XVI e XX - era costurada pela narrativa de uma trajetória indígena: a saga da tribo Caiowá.

Durante o processo de criação de Caixa Postal 1500, os atores eram divididos a partir de seus grupos de interesse temático, sempre relacionados à história do Brasil, principalmente à colonização. As improvisações dramatúrgicas e atorais eram produzidas a partir de referências pesquisadas tanto nas aulas ministradas, no primeiro semestre, pelos professores de História da UFMG, como nas fontes bibliográficas e nos contatos e visitas a grupos indígenas. Como havia o interesse, por parte da equipe de criação, de desenvolver uma visada crítica de nossa história, também foram importantes fontes para as improvisações a observação da realidade cotidiana e dos traços culturais de nossa brasilidade e, delas, saíram os principais núcleos que constituíam os personagens anônimos dessa história: portugueses pobres, degredados de ontem e de hoje, padres em crise com sua sexualidade e com sua fé, negros ativistas e indígenas revoltosos.

Os atores interessados em desenvolver um ponto de vista sobre o Brasil a partir da história de seus povos originais constituíram o núcleo indígena do espetáculo, composto por quatro mulheres e dois homens, sendo um deles um jovem de 18 anos e o outro, um homem de 30 e poucos anos. O material cênico produzido pelo núcleo acabou sendo marcado por essa condição e o forte processo de aculturação que sofria a tribo Caiowá, com um dos maiores índices de suicídio entre jovens do mundo, pareceu especialmente fértil para a criação. A saga ficcional dos Caiowá foi definida, posteriormente, como trajetória central do espetáculo: de seu primeiro contato com o homem branco, no século XVI, ao suicídio, no século XX, do último homem jovem da tribo, que matava, junto com ele, toda a possibilidade de existência futura do povo Caiowá.

Diferentemente dos atores, para quem a criação estava associada ao desenvolvimento de personagens que vivenciavam determinadas situações, para os dramaturgos a investigação passava pelo exercício coletivo de pequenas cenas, nas quais podiam confrontar, a partir de temas diversos, formas textuais e cênicas variadas. 
Uma das práticas colaborativas mais usuais durante todo o processo (...) foi a apreciação dos pares sobre os textos produzidos pelos companheiros, com diferentes graus de profundidade, formato e mesmo qualidade. (...) Pelo desconhecimento do processo, não raro as pessoas chegavam com cenas prontas, quando o objetivo era apenas ter a descrição de uma imagem para, depois, explorar a quantidade de ações que ela poderia suscitar, num exercício de livre interpretação por parte de quem não havia descrito a imagem. Ou seja, uma pessoa trazia uma imagem, e outro participante a "transformava" em uma ação. Para depois virarem cenas ${ }^{3}$.

Tais procedimentos geraram desde cenas em que uma guerra genocida entre indígenas e portugueses se transformava numa batalha de hinos de futebol, até cenas em que ocorria o inusitado encontro entre um folião do século $\mathrm{XX}$, fantasiado de índio, e um silvícola do século XVI ou a devoração simbólica do bispo Sardinha, por meio de um duelo verbal e ideológico que era erigido nas tramas da intertextualidade: de um lado, o manifesto antropofágico da modernidade brasileira, do outro a velha doutrina religiosa como ferramenta de domínio.

Breu da noite, meio da mata. Entra Bispo Sardinha, tentando se guiar na escuridão.

SARDINHA: E o Senhor disse: este é o concerto que farei convosco, depois daqueles dias; porei as minhas leis em seus corações, e as escreverei em seus entendimentos! Pelo sangue do Senhor Meu Deus, nos uniremos!

HANGAY: Só a antropofagia nos une.

(...)

KAMAYRÁ (lambe os beiços): Antropofagia.

SARDINHA: Deus é a luz, a verdade e a vida! Mais forte que a maior força dos homens! Os que trazem sua palavra são igualmente iluminados!

KAMAYRÁ: Nunca fomos catequizados!

HANGAY: Fizemos Cristo nascer na Bahia. Ou em Belém do Pará! (risos)

(...)

${ }^{3}$ COSTA, Marcelo Henrique e PENIDO, Bete. Caixa Postal 1500 IN: Cadernos de Dramaturgia do Galpão Cine Horto: oficinão. Belo Horizonte: Argvmentvm, 2009, vol. 1, p. 33. 
SARDINHA (eufórico): És diferente dos demais gentios, pois entendes facilmente o que digo! Como podeis deixar um (Gesticula, apontando para si) de mesmo entendimento que o teu vagar por estas partes decadentes? Achas direito?

KAMAYRÁ (apalpando os braços do bispo): Perguntei a um homem o que era o Direito. Ele me disse que era a garantia do exercício da possibilidade. Comi-o ${ }^{4}$.

A partir de 1999, com a implantação do Núcleo de Dramaturgia coordenado por Abreu, os processos desenvolvidos pelo Oficinão para Atores passaram a agregar, para além da montagem de um espetáculo, a noção de criação de uma dramaturgia própria capaz de possibilitar ao ator o exercício não só de suas ferramentas interpretativas, mas de sua potência criadora na construção de um arsenal de ações e textos. Nos 10 anos de desenvolvimento do projeto foi perceptível a opção por um novo caminho para as montagens, pois somente três dos dez espetáculos produzidos foram construídos a partir de dramaturgias já existentes e, desses três, dois contaram com a presença de dramaturgistas durante o processo de montagem ${ }^{5}$. Com isso, abriram-se as portas para a experiência colaborativa não só no âmbito do próprio Oficinão, mas também no âmbito da cena mineira, pois tal mudança veio a influenciar significativamente tanto as ações do centro cultural como os modos de criação de diversos grupos teatrais da cidade, entre eles o próprio Grupo Galpão que, em 2000, fez o espetáculo Um trem chamado desejo sob os princípios do processo colaborativo.

Em 2001, o centro cultural inaugurou mais uma oficina de criação e pesquisa teatral: o Núcleo de Direção que, coordenado por Aderbal Freire Filho, buscava, a partir de investigações teóricas e de práticas de cena, o exercício do olhar do encenador - uma vez que a maior parte dos participantes da oficina eram atores interessados em exercitar a direção teatral - mas também o exercício de compartilhamento e troca na criação, em comunhão com a perspectiva colaborativa que começava a nortear as ações do Galpão Cine Horto. Estabelecida a tríade básica do processo colaborativo (atuação, dramaturgia e direção), natural foi convidar Antônio Araújo para pensar uma oficina

\footnotetext{
${ }^{4}$ AUTORIA COLETIVA. Caixa Postal 1.50o IN: Cadernos de Dramaturgia do Galpão Cine Horto: oficinão. Belo Horizonte: Argvmentvm, 2009, vol. 1, pp. 8o-81.

${ }^{5}$ Todos os textos das dramaturgias originais tecidas em processos de criação colaborativa, bem como os ensaios sobre todos os processos de criação realizados nos 10 anos de desenvolvimento do projeto Oficinão, estão disponíveis nos Cadernos de Dramaturgia do Galpão Cine Horto, lançados em março de 2009.
} 
que pudesse juntar esses três pilares numa experiência única e nesse mesmo ano, ele propôs, junto com Abreu, um workshop para os participantes tanto dos núcleos de Dramaturgia e Direção, como do Oficinão para Atores, calcado na realização de um processo intensivo de criação, em que cada função teria a possibilidade de exercitar suas ferramentas criativas na construção colaborativa de uma cena de 15 minutos.

Muitas das cenas criadas durante o workshop tiveram um desenvolvimento posterior e foram apresentadas no Festival de Cenas Curtas do Galpão Cine Horto, como, por exemplo, Às Moscas (com direção de Lenine Martins), uma das Cenas Mais Votadas daquele ano. No entanto, em razão da posição que ocupava em relação aos demais projetos do centro cultural, o Oficinão, embora já contasse com a colaboração dos participantes do Núcleo de Dramaturgia na criação dos espetáculos, era, em geral, coordenado e dirigido por integrantes do Grupo Galpão ou por diretores experientes (parceiros do grupo ou do centro cultural) que eram convidados a exercer a função. Em outras palavras, apesar do projeto já funcionar como um campo de experimentação dramatúrgica e de pesquisa de atuação, não havia interesse, por parte do Galpão Cine Horto naquele momento, de possibilitar que o Oficinão se tornasse também campo de experimentação para os participantes do Núcleo de Direção, a fim de permitir o aprofundamento da experiência vivenciada pelos novos encenadores nas oficinas de processo colaborativo ou nas práticas de criação cênica do próprio núcleo.

Somente a partir de 2008, com a reestruturação do centro cultural e uma profunda avaliação dos projetos, o Oficinão inaugura um novo formato, Oficinão Residência, e passa a selecionar por meio de edital - sistema que já era utilizado para a seleção dos atores - propostas de pesquisa e montagem apresentadas por diretores estreantes, interessados em assumir a coordenação dos trabalhos.

Assim, no final de 2002, após exercitar o formato em uma série de oficinas junto a grupos de alunos de teatro pertencentes ao Curso de Artes Cênicas da UFOP, mas também ao CEFAR e a outros centros de formação existentes em Belo Horizonte, um agrupamento de artistas oriundos dos núcleos de Direção e Dramaturgia, independentes, heterogêneos, inconformados com suas experiências anteriores em grupos (ou fora deles) e desejosos de investigar novos caminhos e procedimentos, se propõem a formar um núcleo de investigação e criação teatral e, ao mesmo tempo, 
realizar uma experiência na qual dialogariam seu processo de criação com os processos de outros coletivos teatrais: nasciam a Maldita e o projeto Cena $3 \times 4$.

O Cena 3×4, realizado em parceria com o Galpão Cine Horto, propunha a investigação dos princípios da criação colaborativa a partir da montagem de um espetáculo de 30 a 40 minutos por núcleos de criação compostos por atores, diretores e dramaturgos. O projeto tinha início em março e estréia em novembro e teve três edições, de 2003 a 2005. Nos dois primeiros anos, ele foi orientado por Antônio Araújo e Luis Alberto de Abreu que, respectivamente, se responsabilizaram por diretores e dramaturgos, além de assumir a orientação conjunta dos atores. No segundo ano, ele contou também com a colaboração de Tiche Vianna, atriz e diretora do Barracão Teatro que, por meio de uma oficina de processo colaborativo ministrada para todos os atores envolvidos no projeto, realizou uma orientação pontual na área de atuação. Em 2005, já sem a presença de Antônio Araújo, o Cena $3 \times 4$ trouxe o diretor Francisco Medeiros que, como Abreu e Tiche, era professor da Escola Livre, para, junto com eles, assumir a orientação dos núcleos de criação daquele ano.

O projeto previa, a fim de permitir a troca e compartilhamento dos processos de criação, encontros periódicos entre os núcleos - por exemplo, ensaios abertos em que um núcleo mostrava materiais e dinâmicas de trabalho para os outros - além de encontros pontuais, os Coletivões, em que todos os núcleos e funções se reuniam com os orientadores para discussão dos processos e do material cênico produzido e para o levantamento de questões referentes às funções artísticas específicas, entre outras coisas. No último ano do Cena 3×4, além dos espaços de compartilhamento já existentes, foram instaurados grupos de discussão para cada função artística presente em todos os núcleos: atuação, direção, dramaturgia e cenografia. Esses grupos eram coordenados pelos integrantes da Maldita e permitiam o aprofundamento de questões relativas aos procedimentos criativos de cada área artística, como técnicas de composição dramatúrgica ou de treinamento atoral.

No primeiro ano de desenvolvimento do Cena $3 x_{4}-$ em que o projeto foi se desenhando e, na própria feitura, definindo seu formato - foram convidados a integrar os núcleos de criação diretores e dramaturgos oriundos dos núcleos de pesquisa do Galpão Cine Horto e grupos teatrais da cidade que eram inteiramente compostos por atores: a Cia. Luna Lunera, o Grupo Trama e o Labapi. A partir da afinidade entre a 
linguagem (ou interesses artísticos) dos grupos e a pesquisa desenvolvida por diretores e dramaturgos, os núcleos eram organizados pela coordenação do Cena $3 \times 4$.

A única exceção foi o núcleo proponente do projeto, formado por artistas e pesquisadores independentes - pois não pertenciam a nenhum grupo de teatro - que tinham se juntado, principalmente, pelo interesse de investigarem, juntos, a criação: a atriz Lissandra Guimarães, os diretores e atores Amaury Borges e Lenine Martins e eu, dramaturga. O núcleo foi definindo sua composição e forma, ele também, na própria feitura, pois, rapidamente, agregaram-se a ele as atrizes Márcia Torquato e Daniela Papini, além do músico Ricardo Garcia e da artista plástica Ines Linke. Mais tarde, a partir do sucesso alcançado por seu primeiro trabalho, Casa das Misericórdias, o coletivo se definiu como um agrupamento de pesquisa cênica e passou a ser conhecido como Maldita Companhia de Investigação Teatral.

\subsection{A dramaturgia rapsódica de Casa das Misericórdias}

Quando começamos o processo, em março de 2003, estávamos trabalhando eu, na dramaturgia, Lissandra Guimarães e as atrizes convidadas Márcia Torquato e Daniela Papini na atuação e, dividindo a direção, Amaury Borges e Lenine Martins. Como havíamos iniciado, em 2001, uma investigação prática de elementos narrativos, a partir de um workshop proposto por Aderbal Freire Filho, optamos por concentrar a pesquisa em dois vetores: na exploração dos mecanismos que ele chamava de "épicodramáticos", ou seja, nos quais ocorrem deslizamentos entre a dimensão épica distanciada, descritiva - e a dimensão dramática - direta e vivenciada - da cena, e na investigação específica de aspectos relativos ao próprio processo de criação colaborativa. A nossa prática coletiva de construção cênica privilegiava, sobretudo, a investigação da especificidade de cada função artística e dos mecanismos de horizontalização da criação.

Em relação à dramaturgia, ou ao objeto que se denomina texto, foi necessário redimensionar seu sentido, usualmente ligado ao trabalho escrito do dramaturgo - ou, mais precisamente, à visão da dramaturgia como literatura dramática ou do texto 
como objeto fixo e imutável, do qual nasce toda a encenação - para considerar o nível da relação entre os materiais/funções compositores da cena. Isto é: no âmbito do trabalho de dramaturgia, foi necessário perceber como organizar a textura da cena enquanto fruto de uma visão artística compartilhada, de modo a permitir a configuração de uma dramaturgia polifônica, de uma dramaturgia da qual emergissem, para a superfície do texto mesmo, as vozes constituintes da criação. Interessava-me, particularmente, as possibilidades de notação de uma dramaturgia tecida não apenas por palavras, mas também por movimentos e espacialidades.

Nesta hipótese, criar uma cena menos do que tecer um novelo de ações, (...) seria constituir uma semântica de superfícies, tessitura de cores e imagens, apresentação de objetos não previamente identificados. Na cena, a significação (...) se afirmará pelas diversas texturas que se alternem numa composição. Suas partes se diferenciarão pela transparência, opacidade, rugosidade, relevo (...). Neste caso, a dramaturgia da cena será mesmo a visualidade e materialidade que se derem a ver ${ }^{6}$.

Havia o interesse, por parte de toda a equipe de criação, de que a pesquisa dos procedimentos colaborativos se refletisse na textura cênico-dramatúrgica resultante. Foi essencial, então, para nossa investigação poética, o estudo teórico e prático do conceito de polifonia ${ }^{7}$, como definido por Bakhtin. Segundo ele, a polifonia pressupõe que, no interior do texto, ressoem vozes eqüipolentes que - não sujeitas a nenhuma espécie de hierarquização, seja no que tange a um organizador externo ou a outra voz relacionam-se em pé de igualdade (BAKHTIN, 2008: 4-5). Desse modo, a voz da personagem, na obra polifônica, se estrutura de modo semelhante à "voz do próprio autor", sendo tão plena quanto a palavra deste e possuindo uma "independência excepcional na estrutura da obra", quase "como se soasse ao lado da palavra do autor". Em outros termos, pode-se dizer que esse dialogismo, ou seja, o confronto entre as vozes é constitutivo e matéria formal da obra polifônica, permitindo, inclusive, a

\footnotetext{
${ }^{6}$ RAMOS, Luiz Fernando. Dramaturgia da cena ou materialidade do espetáculo? IN: Revista do Festival Internacional de São José do Rio Preto. 9-19 julho 2008, p. 89.

${ }^{7}$ Já discutido no capítulo 1 desta tese, no qual examino a relação entre o conceito de polifonia e o processo de criação colaborativa.

${ }^{8}$ BAKHTIN, 2008: 31. Grifos do autor.
} 
insurgência de outras características inerentes ao conceito de polifonia, tais como a heterogeneidade das matérias e a simultaneidade dos planos. Mas um aspecto, sobretudo, nos interessava no conceito de polifonia: que a multiplicidade de vozes, planos e matérias presente na tessitura polifônica, frutos de sua interação e coexistência, resultasse no enfraquecimento da forma dramática.

Ao contrário do encadeamento dramático, de natureza eminentemente temporal - pois uma ação se sucede à outra, avançando sempre do presente, já tornado passado, em direção ao futuro - a simultaneidade dos planos de que fala Bakhtin pressupunha, em nosso entendimento, uma dimensão espacial da textura dramatúrgica, na qual as categorias de coexistência e interação (BAKHTIN, 2008: 31), fundamentais para o entendimento do conceito de polifonia, poderiam se desenvolver plenamente. Em conseqüência disso, a investigação da Maldita acabou sendo, coincidentemente, uma experiência de ocupação de espaços não convencionais ou, em outras palavras, de espaços não destinados à atividade teatral, na qual buscamos perceber em que medida a dramaturgia polifônica se configurava também como uma “dramaturgia do espaço”.

Apontada por Marco de Marinis ${ }^{9}$ como uma das tendências da cena contemporânea, a dramaturgia do espaço agrega, em seu bojo, características e elementos oriundos dos lugares concretos em que a cena e seus criadores estão inseridos. Para Fernando Mencarelli ${ }^{10}$, "os diálogos estreitos dos criadores com seu entorno" é marca também de um "adensamento da grupalidade regida pela autonomia econômica e criativa" dos coletivos teatrais, os quais vão se lançar em um "movimento para fora dos espaços tradicionais do teatro, transformando as ruas, as praças e edifícios variados em espaços teatrais" (MENCARELLI, 2010: 16).

A coincidência mencionada acima está relacionada com o fato de que, apesar do projeto Cena $3 \times 4$ ter como eixo as práticas colaborativas do Teatro da Vertigem, cuja experiência de criação se relaciona diretamente com a ressignificação de espaços públicos, como igreja, hospital, presídio e, mais recentemente, o Rio Tietê, além de ter, nessa "escritura espacial, carregada de impressões e sobreposições" um de seus

\footnotetext{
${ }^{9}$ MARINIS, Marco de. In Cerca dell'Attore. Roma: Bulzoni Editore, 2000.

10 MENCARELLI, Fernando Antônio. Dramaturgias em processo: a cena pelo avesso IN: Cena Invertida: dramaturgias em processo. Belo Horizonte: Edições CPMT, 2010.
} 
aspectos mais marcantes (MENCARELLI, 2010: 17), o Cena $3 \times 4$ previa, inicialmente, que as quatro montagens resultantes do trabalho desenvolvido pelos núcleos de criação fossem apresentadas no Galpão Cine Horto, o que ocorreu com os espetáculos produzidos pelas demais equipes envolvidas no projeto daquele ano.

No caso de Casa das Misericórdias, fruto do processo de criação vivenciado pela Maldita, estava prevista, inicialmente, a utilização, como espaço cênico, de todo o antigo cinema que serve de sede ao Galpão Cine Horto. Posteriormente, com o desenvolvimento da estrutura cênico-dramatúrgica, percebemos que qualquer edifício que, da perspectiva do público, fosse visto como espaço destinado a apresentações teatrais, não poderia servir aos propósitos do trabalho. A partir desse dado, já em agosto daquele ano definimos como espaço de encenação uma antiga casa-bar abandonada, localizada nas imediações do centro cultural. Esta era uma construção insólita, fechada há muitos anos e que havia sido, anteriormente, um tradicional bar da região, a Gruta.

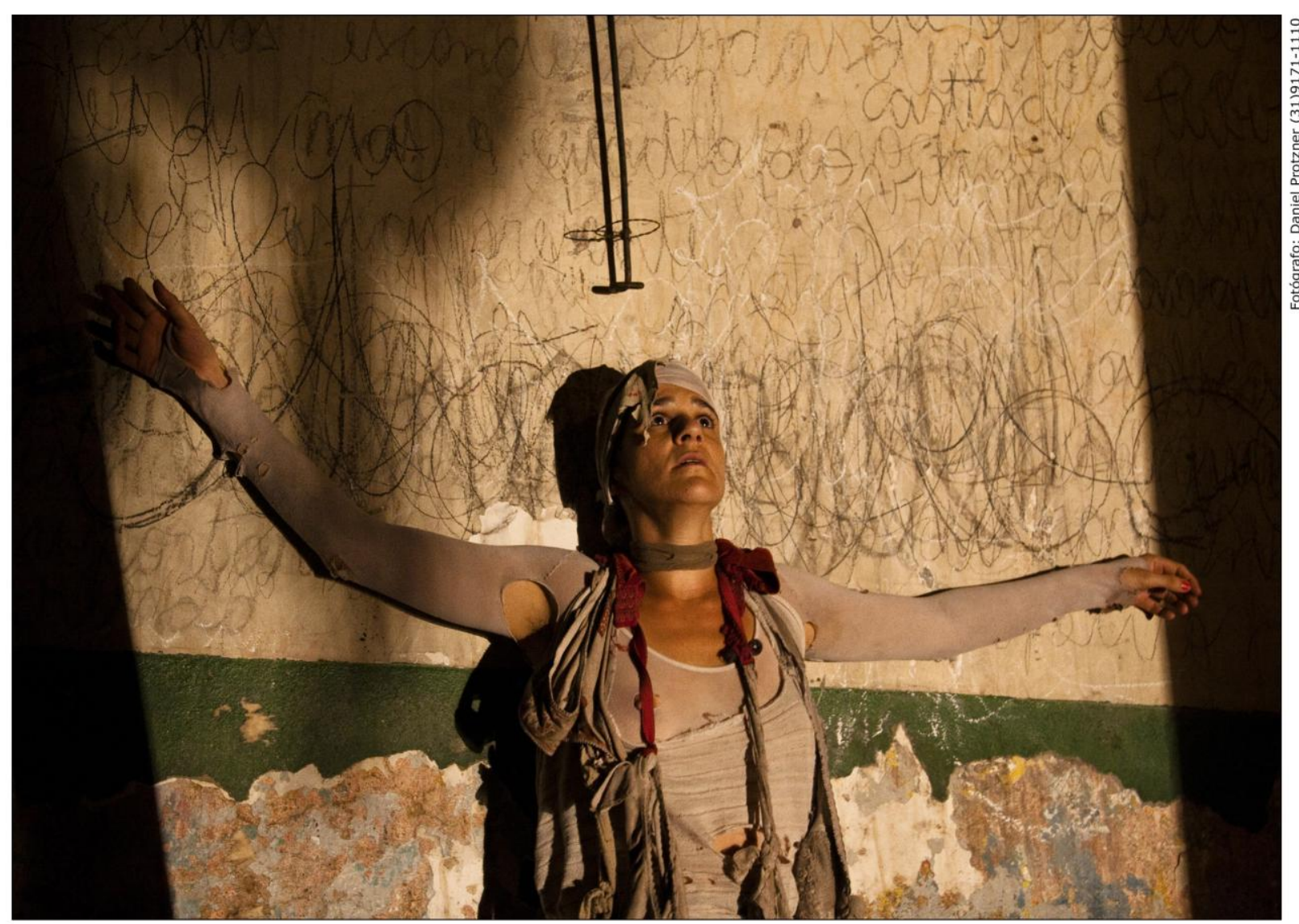

"Casa das Misericórdias" - Maldita Cia. de Investigação Teatral (Belo Horizonte/MG) / Local: Gruta

FIG. o1 
Ao tomar posse do lugar, a Maldita, em homenagem ao antigo reduto boêmio, manteve o nome pelo qual ele era conhecido no bairro Horto e o transformou em sede. A construção era inusitada porque, tendo sido casa, fora transformada em uma espécie de galpão mediante o fechamento e incorporação do pátio que havia em frente à edificação. O pátio fora coberto por telha de zinco e cimentado, mas mantinha, ainda, uma antiga cisterna em seu centro. Uma escada de madeira dava acesso à marquise que fazia parte da fachada da casa e à laje que existia sobre os cômodos. A fachada da casa, com duas portas e duas janelas, incorporava, ainda, um balcão de bar, resquício, sem dúvida, do período em que o lugar se tornara a Gruta.

Em relação ao eixo temático que orientava nosso processo de criação, pode-se dizer que ele estava atrelado ao aspecto poético do trabalho que pretendíamos realizar. Como para os participantes do processo havia a confluência entre elementos estéticos e ideológicos, uma vez que pretendíamos investigar as estruturas de poder por meio tanto da pesquisa de procedimentos horizontais de criação como por meio da discussão das relações entre instituições sociais e indivíduos, elegemos como ponto de partida uma questão polêmica, a loucura, e como base teórica para nossa investigação sobre corpo e poder, a obra de Foucault, que possibilitava uma análise profunda das relações micro-políticas entre sociedade, psiquiatria e loucura ${ }^{11}$.

A partir da pesquisa do procedimento poético de base, ou seja, dos mecanismos "épico-dramáticos" propostos por Aderbal Freire Filho - tais como o contraponto da ação realizada por meio de sua descrição e a alternância entre o discurso direto e o discurso indireto por meio do uso da primeira e da terceira pessoa, além de outros que inventamos a partir destes - a equipe de criação buscou explorar elementos polifônicos em todos os níveis da encenação para discutir, por meio da construção de pontos de vista distintos sobre os acontecimentos postos em cena, a relação entre o indivíduo considerado louco e a instituição que o define. Além de Foucault, foram fontes de pesquisa para a criação, a obra de alguns artistas nos quais a vida e a vivência da

\footnotetext{
${ }^{11}$ Foucault especializou-se em análises que consideravam as micro-estruturas do poder, utilizando, sobretudo, o método que ele denominava de arqueológico, no qual ele questionava a linha evolutiva da História, como em A História da Loucura na Idade Clássica (FOUCAULT, São Paulo: Perspectiva, 1999); e o método genealógico, no qual ele buscava perceber, a partir das práticas e dos dispositivos utilizados socialmente, como as coisas tomavam forma, como em Microfísica do Poder (FOUCAULT, Rio de Janeiro: Graal, 2003), só para citar duas obras que foram base para nossa pesquisa teórica.
} 
loucura e da instituição manicomial se misturavam à arte, como Artaud, Lautréamont, Artur Bispo do Rosário e a escritora Maura Lopes Cançado.

Tínhamos como vasto horizonte a loucura e o desejo de discuti-la na relação com as instituições. No entanto, em março, quando iniciamos o processo, estávamos concentrados ainda na investigação poética de mecanismos cênicos a partir de fragmentos textuais diversos e tomávamos conhecimento de nosso tema somente por meio de leituras e conversas. Em abril, quando tivemos o primeiro Coletivão e encontro com nossos orientadores para a mostra dos materiais cênicos produzidos, além de levantamento de questões relativas aos processos vivenciados, fomos duramente questionados por Antônio Araújo e Abreu em relação à abordagem teórica que fazíamos do tema, pois as improvisações cênicas e textuais, balizadas somente na leitura das obras de referência, não tinham densidade humana, eram apenas projeções cênicas de um discurso (ainda que bem intencionado) sobre a loucura.

O encontro com os orientadores resultou em uma reviravolta no rumo do trabalho e partimos, então, para o contato mais direto com a experiência concreta, humana e social da loucura. Começamos as visitações aos loucos de rua e hospitais psiquiátricos e demos início a laboratórios e vivências de estados alterados, por meio de exercícios que trabalhavam com a percepção cotidiana. O Hospício de Barbacena, em especial, nos tocou profundamente. Símbolo da luta antimanicomial, o hospital colônia notabilizou-se a partir de 1979, com a visita do psiquiatra italiano Franco Basaglia que o classificou de "campo de concentração nazista”. Nesse mesmo ano, o jornalista Hiram Firmino publicou, no Estado de Minas, uma série de reportagens intitulada Os Porões da Loucura e o cineasta Helvécio Ratton realizou o curtametragem Em nome da razão, nos quais ambos denunciavam as condições subumanas de vida dentro do hospício.

Conservando uma população de antigos internos, remanescentes de uma época da história da psiquiatria em que o contingente de um manicômio como esse chegava a 400 pessoas, o Centro Hospitalar Psiquiátrico de Barbacena (nome pelo qual é conhecido atualmente) abriga, ainda, o Museu da Loucura. Suas salas, repletas de antigos prontuários de internação e de instrumentos médicos utilizados na contenção e tratamento dos internos - muitos dos quais, como os aparelhos de eletrochoque e máscaras de ferro, lembram aparelhos de tortura - guardam não só a história do lugar, 
mas também, de certo modo, a história do tratamento psiquiátrico no Brasil. Nos prontuários, por exemplo, fica evidente que o sanatório funcionava como ponto de convergência para todos aqueles que a sociedade pretendia curar ou isolar, pois nele eram internados desde doentes mentais até pessoas marginalizadas, como sifilíticos, mendigos bêbados, mães solteiras e filhos problemáticos.

Também em abril, tivemos uma importante aquisição que modificou substancialmente a configuração da pesquisa: entraram para a equipe de criação o músico performer Ricardo Garcia (nosso “dramaturgo musical”) e a artista plástica e cenógrafa Ines Linke (nossa "dramaturga do espaço"). O trabalho com esses dois artistas fortaleceu muito um aspecto que já se apontava: a investigação de uma dramaturgia tecida dos cruzamentos e superposições de ações físicas, verbais, sonoras e espaciais em uma teia polifônica de sentidos.

Tendo a polifonia como ponto de partida para a criação da dramaturgia, comecei a buscar matérias textuais diversas - sugestões de imagens, trechos de contos, documentos históricos, reportagens - que pudessem ser dilatadas em improvisações. $\mathrm{O}$ universo de Maura Lopes pareceu às atrizes (e também à dramaturga) o mais instigante e nos concentramos nele. Tratava-se da escritora esquizofrênica que, após assassinar sua companheira de quarto em um hospital psiquiátrico e ser rejeitada tanto nas prisões femininas - por ser louca - como nos manicômios destinados a mulheres por ser assassina - é trancafiada em uma cela isolada de um manicômio judiciário masculino, no qual, sem direito a tratamento médico, fica cega. Pesquisei, então, além de O Hospício é Deus, diário que Maura Lopes escreveu ainda dentro dos manicômios, outras fontes e referências, como seu premiado livro de contos, O sofredor do Ver, e uma série de matérias que tinham sido feitas por uma repórter do Jornal do Brasil, como tentativa de trazer à tona a situação absurda em que a escritora se encontrava, a fim de tentar forçar, com o apoio da opinião pública, sua libertação ou, pelo menos, conseguir condições mais humanas de tratamento.

A partir das improvisações geradas por essas fontes (principalmente pelas reportagens), começamos a ter um material cênico muito rico em torno da idéia de visitas, feitas por indivíduos do mundo exterior, como jornalista, atriz, pesquisadora, às internas de uma instituição manicomial. Brincávamos com a primeira e a terceira pessoa, criando jogos em que cada atriz narrava as ações sob o seu ponto de vista. Tais 
jogos propiciavam o surgimento de perspectivas muito distintas, em que o fato, o acontecido, era colocado em questão. Por outro lado, os deslizamentos entre as duas instâncias - a instância do vivido e a do observado - nos possibilitava tocar em conteúdos dramáticos sem que incorrêssemos no melodrama.

JORNALISTA - Terceira visita. A jornalista entra no cubículo imundo. Pontas de cigarro por todo lado. Moscas bóiam nas canecas de café frio.

MAURA - Ninguém visita a interna do cubículo 2.

JORNALISTA - Maura me recebe de camisola. Ela está deitada na cama suja. Descabelada, angustiada. Maura está cega.

MAURA - Trouxe um cigarro?

JORNALISTA - Como ela pode viver nesse inferno? Não, não trouxe. Eu não fumo. Ela coloca nas mãos de Maura um sanduíche que trouxe da rua.

MAURA - Maura o devora faminta, apressada. Você não sabe o que é ficar cega. Não como mais a comida daqui. Tenho medo. Outro dia me trouxeram uma carne podre. Cheia de bicho. Fedorenta!

JORNALISTA - Maura cheira mal. Sem querer, ela eu estremeço de nojo. Você toma banho? (Que pergunta idiota!)

MAURA - Você toma banho. Sabonete Lux Luxo ${ }^{12}$.

Como tínhamos a construção de um work in process em nosso horizonte de expectativa, havíamos escolhido, deliberadamente, trabalhar em um sistema de criação orientado (e desorientado) pela Teoria do Caos, a partir das premissas expostas por Rubens Rewald em Caos/Dramaturgia ${ }^{13}$. Segundo Rewald (2005: XVI), a criação processual no teatro, diferentemente do cinema, permite o aprofundamento de diversos conceitos relacionados à Teoria do Caos, como, por exemplo, os de complexidade, imprevisibilidade e dependência sensível às condições, bem como as noções de ruído, flutuação e sistema, pois, nesse caso, a "relação entre caos e dramaturgia passa a ocorrer no nível externo ao texto, ou seja, no processo de construção desse texto". Ele afirma que, de modo diverso do cinema, no qual os conceitos são trabalhados "como elementos da diegese da obra”, no processo de criação colaborativa eles passam a ser pesquisados como instrumentos de construção

\footnotetext{
${ }^{12}$ Trecho de $A$ terceira visita, improvisação textual de maio de 2003, retirada do caderno de dramaturgia da autora.

${ }^{13}$ REWALD, Rubens Arnaldo. Caos/Dramaturgia. São Paulo: Editora Perspectiva, 2005.
} 
dramatúrgica. Ao utilizar os conceitos e noções da Teoria do Caos como instrumentos para a criação, "a pesquisa deixa de centrar a fábula, a história, para se concentrar no processo de construção dessa história”.

Para Rewald (2005: XVI), a maior parte desses conceitos concerne, dentro do processo de criação colaborativa, diretamente ao trabalho do dramaturgo. Assim, a dependência sensível às condições se refere à permeabilidade do dramaturgo em relação a quaisquer elementos surgidos em conversas ou improvisações que possam suscitar nele "todo um manancial de novas idéias e possibilidades de desenvolvimento do texto". O conceito de imprevisibilidade diz respeito à percepção do dramaturgo em relação às alterações - propositais ou acidentais - que possam ocorrer durante os ensaios ou apresentações e implica no aproveitamento dessas mesmas alterações - que podem ser ruídos ou flutuações - para o enriquecimento da obra em construção. E, por fim, o conceito de complexidade está relacionado a uma percepção mais ampla de que a obra é resultante das interações ocorridas entre os participantes do processo de criação, e que, em função disso, ela está sempre "em permanente evolução, continuamente se reprocessando e se auto-organizando".

Ainda segundo ele, (REWALD, 2005: 22-23), para a evolução da obra é absolutamente necessária a ocorrência de ruídos - eventos aleatórios, cujo surgimento terá sempre um efeito imprevisível no processo - ou de flutuações - movimentos que são provocados pelo próprio processo, tirando-o de seu equilíbrio - que levam o sistema a se rearticular e a criar novas possibilidades de resposta por parte da dramaturgia, da encenação ou da atuação. Em outras palavras, durante o processo de criação artística, “a ordem é perturbada pela desordem, originando discussões, reelaborações, equívocos, soluções e descobertas. Essa perturbação obriga o processo a se reorganizar em outro patamar", fazendo com que a obra evolua.

Em nosso processo de criação colaborativa, aplicávamos os conceitos da Teoria do Caos ao trabalho de todas as áreas. Assim, diante de determinados estados estáticos - como a acomodação criativa de determinado setor - provocávamos flutuações que possibilitavam "abalos" no sistema e permitiam à criação avançar. Foi o caso, por exemplo, das intervenções de Amaury Borges no campo da cenografia: o diretor, sentindo necessidade de elementos que verticalizassem as relações entre o espaço e a composição de ações pelos atores e pela dramaturgia, lançou uma provocação à 
cenógrafa, marcando em planta baixa, à moda de Dogville, filme de Lars Von Triers, os lugares institucionais a serem percorridos pelos atores e a cenógrafa, Ines Linke, reagiu com proposições de um uso subjetivo do espaço. Posteriormente, essas proposições foram concretizadas na proposta de cenografia que orientou a ocupação da Gruta, assunto que retomarei mais tarde.

\section{Proposta Espacial 1}

Acontecimento: ponto de encontro de intensidades ou o cruzamento de linhas de uma trama existente; pontos de convergência e irradiação das linhas pelas quais se constrói o tempo e a história. O espaço do público e da ação é compartilhado.

Proposta prática: Corda, elástico redondo, elástico largo com texto, barbante, fio.

Experimento um: Uma trama no chão, na parede e uma trama na altura do marco da porta.

Materiais: ganchos, buchas, elástico.

Experimento dois: Cordas funcionais e estruturais atravessando o espaço (fig. 2).

Materiais: corda, pontos de apoio.

Experimento três: Teia de barbante sendo tecido pelos atores durante a apresentação, de forma caótica, envolvendo o espaço e o público dificultando a movimentação. Ganchinhos nas paredes, portas, marcos cadeiras...

Materiais: ganchos, buchas, barbante.

Proposta Espacial 2

O labirinto do espaço dá-se através da redundância de limites físicos. Os elementos e materiais são deslocados do convívio social de espaços públicos e privados. Eles formam parte do dia a dia, como objetos de proibição simbólica ou concreta que separam e regulam a convivência.

\section{Proposta prática:}

Materiais da vida cotidiana com vários graus de transparência e objetos (telas, malhas, redes, vidro, plástico, cercas, cordas, tubos, arames, persianas e correntes...e outras?) são acumulados em forma labiríntica. O chão da área é coberto de cacos de vidro. Através das variações de densidade dos materiais, se forma um espaço em forma de labirinto que convida à circulação ${ }^{14}$.

\footnotetext{
${ }^{14}$ Proposta de cenografia enviada por Ines Linke em agosto de 2003 e documentada no relato do processo.
} 
Na maior parte das vezes, as flutuações no sistema, geradas pela aplicação da Teoria do Caos ao processo de criação, traziam benefícios, mas em outras geravam abalos que provocavam crises ainda maiores. Foi o caso das alterações ocorridas no campo da atuação. No final de maio, em plena explosão criativa, uma das atrizes convidadas, Márcia Torquato, em desacordo com a condução de um dos diretores, Amaury Borges, entrou em crise e abandonou o posto, passando a fazer o relato do processo. Com a saída de Márcia da cena e com a permanência de Daniela Papini e Lissandra Guimarães na atuação, decidimos aprofundar os materiais cênicos surgidos das improvisações em torno da vida e obra de Maura Lopes a partir de sua interação com o universo do sagrado, profundamente entrelaçado na vida e obra de Artur Bispo do Rosário.

Com a interação dos materiais produzidos por essas duas fontes de pesquisa, alguns exercícios com a palavra, nos quais ela era desconstruída e recomposta em outros significados, evoluíram para a produção de jogos verbais e sonoros em que determinados sentidos também deslizavam ou, por outra, se revelavam entre as frestas dos enunciados. Além de exercícios de desconstrução da palavra, manipulávamos, ainda, diferentes tipos de discurso - jornalístico, bíblico, literário - que propiciavam à dramaturgia construir contrapontos estilísticos mais fortes. Vimos surgir daí uma mulher que, em plena potência feminina, se dizia deusa. Parti, então, para a construção, junto à atriz Lissandra Guimarães, de textos nos quais se misturavam trechos ou palavras pornográficas às orações católicas.

Enquanto Lissandra desenvolvia um ponto de vista lírico, voltado para o seu mundo interno, Daniela Papini desenvolvia o comentário. Senti necessidade de reforçar o aspecto narrativo do material cênico desenvolvido por Lissandra e me apropriei de trechos literários, que iluminavam suas ações físicas e produziam fortes metáforas das situações vivenciadas em cena. É exemplar a utilização de trechos de Cantos de Maldoror, de Lautréamont, na descrição feita por Laurinda (nome da interna improvisada por Lissandra, que começava a ganhar corpo) dos abusos sexuais que sofria no manicômio e que, mais tarde, viria a se transformar, em Casa das Misericórdias, na cena em que ela descreve um aborto a que é submetida por sua família. 
ATRIZ - Enquanto me ajoelho diante dela, penso (Será que eu entro nesse jogo?), penso que ela é perigosa. Laurinda faz o sinal da cruz e vejo seu sexo peludo e sujo. Sinto o cheiro fedorento da sua buceta.

LAURINDA - O cheiro de coxas... E sobre a porta entreaberta do antigo convento, uma lanterna vermelha, estandarte do vício, balança sua carcaça ao açoite dos quatro ventos... Fé dorenta Fé! A porta se abre, deixando pular para o ar livre um homem. Assim que o cliente sai, uma mulher nua se dirige a um balde, cuja água ensaboada já havia visto se erguerem e caírem gerações inteiras.

ATRIZ - Laurinda fala disparates. Os olhos brilham, arregalados, enquanto me tece com seus barbantes. Que atriz maravilhosa Laurinda não seria!

(Eu quero sair daqui. Eu preciso sair daqui.)

LAURINDA - Galos e galinhas acorrem em multidão dos diversos pontos do pátio, atraídos pelo odor odorenta da buceta seminal... Eles derrubam a mulher, apesar dos esforços vigorosos que ela fazia, e pisoteiam a superfície do seu corpo como se fosse um monte de esterco! Depois, rasgam a bicadas, até sair sangue, os lábios flácidos da sua buceta inchada, da sua bendita buceta inchada. (bendita é Laurinda entre todas as mulheres). Então, já com as vísceras saciadas, vão novamente ciscar a poeira do pátio e Laurinda, limpa, levanta-se trêmula, cobertas de feridas, como alguém que desperta de um pesadelo...

ATRIZ - (Por que não grito? $)^{15}$

A “deusa” tinha adquirido uma força quase pagã. Percebíamos que a idealização em relação à loucura - encarada por nós como brava resistência a uma sociedade doente - nos ameaçava a cada minuto. A intervenção precisa de Ricardo Garcia, com suas proposições de ambientações sonoras, impediu-nos de cair em uma visão excessivamente romantizada. Descobrimos o rádio. Ou melhor, a rádio e as possibilidades de estranhamento e diálogo que, com sua presença aleatória, a emissão radiofônica podia causar. Com as improvisações geradas nos jogos sonoros, algumas estruturas dramatúrgicas começaram a se fortalecer e, com elas, a idéia de tecer a dramaturgia a partir do cruzamento de tramas paralelas que seriam acionadas por essas mesmas sonoridades.

${ }^{15}$ Trecho de $A$ atriz de si mesma, improvisação textual de junho de 2003, retirado do caderno de dramaturgia da autora. 
Novo abalo sísmico: também pressionada pela condução de Amaury Borges, Daniela Papini abandonou o processo. Diante desse abalo - dessa vez, bem maior - o caos se instaurou. O que fazer? Não queríamos monólogo. Não queríamos introduzir ninguém alheio ao processo. Como tínhamos duas pessoas dividindo a direção do trabalho, Lenine Martins resolveu assumir a atuação, deixando a encenação totalmente a cargo de Amaury. Já não eram mais exclusivamente mulheres atuando. Isso, evidentemente, alterou a configuração do material cênico, uma vez que aquele ator criador, como sujeito no mundo, tinha outras questões a colocar. Com a imagem de Laurinda ainda fecunda, nos lançamos em mais improvisações e surgiu o Guarda da prisão.

Nova configuração atoral, novas proposições cênicas, mais arriscadas. Lenine Martins, ator dotado de um forte preparo corporal, que ia do treinamento com máscaras até técnicas de contato improvisação, não tinha pudores em colocar seu corpo em risco, na exploração dos espaços. O repertório de ações dos atores crescia e surgiam embates mais precisos, com maiores níveis de tensão e, em conseqüência, de teatralidade. O caminho dos atores, extremamente físico, perceptivo e emocional, fortalecia a necessidade de estruturas dramatúrgicas mais amarradas e de mecanismos de distanciamento. Partimos para a investigação de elementos épicos, que permitiam aos atores brincar, em suas improvisações, com as possibilidades de criar ilusões cênicas para quebrá-las em seguida, em criar pequenas ficções, armadilhas para o espectador desarmar.

Amaury insistia para que abríssemos mais uma frente: uma visita que, ao contrário do Guarda, fosse realmente de fora daquele ambiente. Ou seja, um observador épico. Ele insistia também em aprofundar a pesquisa de ações a partir do universo de Bispo do Rosário que, para ele, havia sido pouco explorado por nós. Rearticulei, então, junto aos atores, as proposições dramatúrgicas que giravam em torno da Atriz - improvisada anteriormente por Daniela Papini - que fazia visitas ao manicômio como parte de seus laboratórios de criação. Dessa vez, a visita seria feita a um homem. Lenine e Lissandra começaram, assim, a trabalhar a imagem de uma atriz que visita um interno, um homem que, como Bispo do Rosário, confunde-se com a dimensão divina, um homem-Deus que, em meio a uma revoada de anjos, tece labirintos de palavras. 
Nesse ponto é que começamos, de fato, a aprimorar o que chamávamos, na esteira de Aderbal Freire Filho, de mecanismo épico-dramático e que, como já disse, consistia no deslizamento entre a instância dramática e a instância épica. Contudo, o trabalho que era realizado pela Maldita já havia extrapolado essas duas dimensões: era perceptível que a manipulação do discurso indireto, da narrativa e das formas de composição textual - que, no nosso caso, incluíam escritas em vários materiais, como corpo, roupas, parede - bem como os contrapontos entre a narrativa e as ações físicas realizadas pelos atores, produziam, para além da relação contraditória entre o épico e o dramático, desde significações diversas para os objetos manipulados por eles em suas improvisações até a criação de espaços e tempos subjetivos, distintos para cada persona que transitava em cena.

Denominávamos de persona, no âmbito do trabalho da Maldita, a instância de atuação que ficava a meio caminho entre o performer e o personagem e que permitia, ao ator, transitar de uma relação imediata com o espectador - a partir do contato físico mais direto e de uma vivência plena das ações - à construção de jogos de cena que brincavam com a objetividade épica - nos quais o que era dito confrontava-se com o que era concretamente realizado pelo ator - e com a subjetividade lírica, nos quais as relações intersubjetivas, ancoragem maior do personagem e do drama, eram colocadas em xeque.

Dessa perspectiva, o termo épico-dramático parecia já não ser suficiente para designar o princípio de construção cênico-dramatúrgica operado pela Maldita, o qual se aproximava mais do conceito de rapsódia (SARRAZAC, 2005: 184), uma vez que este ultrapassa a noção de uma simples contraposição entre o modo épico e o modo dramático - presente na designação empregada por Aderbal Freire Filho - para engendrar, por meio de procedimentos de escritura tais como a hibridação, a montagem, a coralidade, a junção entre formas teatrais e extra-teatrais e a tensão entre elementos heterogêneos, uma escritura caleidoscópica, estruturada dinamicamente.

Trata-se, antes de tudo, da realização de um trabalho sobre a forma teatral: de decompor-recompor - componere, isto é, juntar e confrontar ao mesmo tempo - segundo um processo criativo que projeta a escritura dramática em seu devir. É precisamente o estatuto híbrido, até monstruoso, do texto 
produzido - essas sobreposições sucessivas da escritura que sintetizam a metáfora do "texto-tecido" - que caracteriza a rapsodização do texto, permitindo a abertura do campo teatral a uma terceira via, isto é, a um outro "modo poético", que associa e dissocia, ao mesmo tempo, o épico e o dramático ${ }^{16}$.

A meu ver, a complexidade contida na constelação rapsódica, (SARRAZAC, 2005: 184) respondia mais plenamente ao princípio de polifonia que orientava nossa investigação poética e, à medida que esta se aprofundava, a dramaturgia aprofundava, também, as possibilidades de uma composição que me permitisse explodir, por meio da sobreposição e recomposição de elementos textuais múltiplos, de múltiplas textualidades, as fronteiras e limites das formas e introduzir, no seio da tessitura temporal, tipicamente dramática, uma textura espacializada e polifônica.

Quem é Aquele que obriga a Mulher a se ajoelhar, que a espancatortura?

Aquele Homem não serei eu? Serei eu?

Deus devora os homens, pisa em sangue e mijo.

Deus obrava.

O Homem defeca pó farinha e novamente come. Início meio e fim da criação.

O Homem sussurra pela fresta palavras que Ela repete.

Abocanhar mastigar engolir digerir evacuar

Abo canhar masti gar engo lir dige rir e vacu ar

A boca nharma stig arengo lirde ge rir Eva cuar

$A b$ oc anha $r$ mas tig aren gol ird iger irev ac uar

A boca arma stigma rir Eva cu ar.

E Ela repetia tudo. Tudinho. Se ele é deus, qual a sua obra? A Mulher se pergunta.

Homem miserável. Debilitado fisicamente. Magro. Viciado em tabaco. Problema respiratório e um câncer no cu. Cercado de corredores brancos. Sem esperança. Esquecido dos homens. Esquizofrenia. Oligofrenia. Paranóia.

\footnotetext{
${ }^{16}$ SARRAZAC, Jean Pierre. Rhapsodie IN: Lexique du drame modern et contemporain. Belval: Les éditions Circé, 2005, pg. 184. Tradução minha do original, em francês: "Il s'agit donc avant tout d'opérer um travail sur la forme théâtrale: de décomposer-recomposer - componere, c'est à la fois assembler e confronter - selon un processus créateur qui envisage l'écriture dramatique dans son devenir. C'est alors précisément le statut hybride, voire monstrueux du texte produit - ces recouvrements successifs de l'écriture que synthétise la métaphore du 'texte-tissu' - qui caractérise la rhapsodisation du texte, permettant l'ouverture du champ théâtral à une troisième voie, c'est-à-dire à un autre 'mode poétique', qui associe et dissocie tout à la fois l'épique et le dramatique".
} 
A mala ambulante dos hospícios.

Tem louco para tudo, sabe? Pra tudo.

Ela precisa escrever des-espera-da-mente.

Paredes. Papel. Pele. Ela precisa dessas palavras. Escrita.

As paredes brancas do hospício. O olho de Deus. Laurinda pensava colorido. Deus vigia. Deus pune. Deus foi o demônio da minha infância ${ }^{17}$.

Por outro lado, a cenógrafa Ines Linke trabalhava com proposições de uso do espaço a partir das relações subjetivas que fossem travadas com ele. Com isso, tínhamos passado a explorar as múltiplas dimensões de espaço/tempo - os cronotopos de que fala Bakhtin ${ }^{18}$ - habitados pelas subjetividades em cena. Segundo Bakhtin (1993: 211), o cronotopo artístico é caracterizado por uma espécie de fusão dos índices temporais e espaciais, que vai formar um todo compreensivo e concreto. Nele, "o tempo condensa-se, comprime-se, torna-se artisticamente visível; o próprio espaço intensifica-se, penetra no movimento do tempo, do enredo e da história”. A partir, por exemplo, da noção de "espaço de dentro", trabalhávamos os espaços intrasubjetivos, os espaços mentais de delírio e de memória, nos quais se fundiam as noções de tempo passado/futuro e espaço real/imaginário. Para Bakhtin, é justamente esse cruzamento de séries e fusão de sinais que vai caracterizar o cronotopo, pois, nele, "os índices do tempo transparecem no espaço, e o espaço reveste-se de sentido e é medido com o tempo" (BAKHTIN, 1993: 211).

Em agosto, com o avanço do pensamento sobre a dramaturgia que estávamos compondo, tornou-se patente que, para nós, não bastaria deslocar o espaço cênico da sala destinada às apresentações teatrais para todo o edifício que servia de sede ao Galpão Cine Horto. O antigo cinema já havia ocupado, no imaginário da cidade, o lugar de "teatro". Queríamos um espaço que pudesse interferir, diretamente, na composição do texto cênico. Lenine Martins se lembrou de um lugar, nas imediações do Cine Horto, que havíamos, anteriormente, pensado como sala de ensaios. $\mathrm{Na}$ ocasião, devido às condições de abandono em que ele se encontrava, havíamos desistido de utilizá-lo. Agora, justamente por suas condições precárias e arquitetura

\footnotetext{
${ }^{17}$ Trecho de $O$ cu de Deus, roteiro dramatúrgico de julho de 2003, retirado do caderno de dramaturgia da autora.

${ }^{18}$ BAKHTIN, Mikhail. Questões de literatura e estética: a teoria do romance. São Paulo: Unesp, 1993.
} 
insólita, ele novamente nos interessava. Fomos visitá-lo mais uma vez, agora com outros olhos. Os atores propuseram uma rápida ocupação espacial, e vimos que o lugar era bastante potente. No mesmo mês, passamos a ocupar a Gruta.

Um trabalho mais pontual se fez necessário e partimos para o aprofundamento de áreas específicas da encenação: as sonoridades exploradas no processo de criação tiveram suas funções dilatadas, criando desde paisagens sonoras até encadeamentos dramatúrgicos aleatórios, provocados pela manipulação do objeto rádio pelo ator Lenine Martins. O rádio ganhou, a partir desse trabalho, uma enorme importância dentro da estrutura de ações do ator e da composição dramatúrgica, pois, sintonizado em uma rádio evangélica durante as apresentações de Casa das Misericórdias, acabava por criar sentidos inusitados a partir da relação entre a emissão radiofônica não controlada e os acontecimentos ocorridos em cena.

Além disso, o conceito de paisagem sonora, explorado por Ricardo Garcia, culminou na construção de "tapetes verbais", tecidos pelos atores a partir de uma emissão contínua e sussurrada de palavras que, em determinados momentos, ganhavam volume, para serem escutadas pelos espectadores e criar um contraponto com o discurso principal, geralmente emitido pelo outro ator em cena. Esses tapetes alteraram não só a composição dramatúrgica, como ainda a própria notação textual.

Durante todo o processo, havia a tentativa, por parte da dramaturgia, de concretizar, em termos escritos, a composição que existia entre o gesto e a palavra, o corpo e o espaço. Diante da impossibilidade de dar conta do todo da cena - pois parecia ser possível, somente, realizar uma descrição dela, mas não uma composição dramatúrgica que recobrisse todos os aspectos presentes na escrita cênica - resolvi me concentrar na produção, em termos textuais, de espacializações que abarcassem tanto a simultaneidade de ações como o tapete verbal que emprestavam sentido à cena.

GUARDA - Sete e dez... É hora de ir pro serviço. Até mais ver. João de Deus sai do bar e vira a esquina. Para em frente ao manicômio: é preciso tomar coragem. João de Deus observa os muro. E antes de atravessar os portão do inferno, ele pega rezando um pai nosso que estais no céu, santificado seja o vosso nome, venha No interior do cubículo, soa a voz a nós o vosso reino, seja feita a vossa da mulher (rezas simultâneas). vontade, assim na terra como no céu. LAURINDA - Salve, Laurinda, cheia de 


\author{
O pão nosso de cada dia nos daí hoje, racha. Beleza, rachadura, esperança nossa \\ Perdoai as nossas ofensas, assim \\ Venha a nós que recorremos a vós assim \\ como nós perdoamos a quem nos \\ Degenerados Pervertidos Amoralizados \\ tem ofendido \\ Só vos difama, proclama, no mais \\ Não nos deixeis cair em tentação \\ profundo do espírito... O prazer é a \\ mas \\ solução, o prazer é a salvação! \\ livrai-nos do mal. Amém \\ Gozem, amem amem amem
}

GUARDA - O Guarda atravessa o corredor até se deparar com o pavilhão onze. Aqui, antigamente, era cheio de doido. Agora tá tudo vazio, só tem Laurinda. O médico aparece uma vez na vida, outra na morte. E há muito que o guarda faz as vez de enfermeiro. É ele eu que dou comida, dou remédio, dou tudo: eu é que cuido de Laurinda. E João de Deus vai levando... mas é que ele tem uma missão:

LAURINDA - Mais uma "Semana Santa"...

GUARDA - Salvar a alma dessa mulher. (Laurinda irrompe pela porta). ${ }^{19}$

Além da área de sonoplastia, foi aprofundado também o trabalho realizado por Ines Linke, principalmente no que dizia respeito ao uso de objetos triviais presentes no cotidiano de uma instituição total e que ela já vinha introduzindo na textura da cena: elásticos, papéis, latas, tecidos e plásticos. Tais objetos estavam relacionados - seja na dimensão do material do qual eram produzidos, seja na dimensão da forma ou da cor a uma instância de normalização e uniformização do indivíduo. Ações físicas foram propostas, a fim de começarmos a instaurar uma codificação mais precisa da utilização e significações dos objetos que encontravam, em nosso processo de criação, uma multiplicidade polissêmica.

A percepção dos objetos e do espaço como elementos presentes e vivos é a base da encenação (...). Focalizamos a suspensão da concretude do espaço e dos objetos familiares relacionados a ele, atribuindo valores subjetivos e coletivos. (...) Desenvolve-se uma produção de objetos e ações análogas ao real nas quais os símbolos criados existem com referência à realidade. As experiências revelam as potencialidades dos elementos para criticar os hábitos automáticos, as crenças e valores, a organização monótona dos dias e a concepção de uma vida normal que rege as relações diárias (LINKE, 2008:27).

\footnotetext{
${ }^{19}$ CAETANO, Nina. Casa das Misericórdias. Trecho da última atualização dramatúrgica, feita durante a remontagem de março de 2007 (Ver Anexo A)
} 
Com o aprofundamento das áreas específicas e o entrelaçamento das diversas matérias presentes na cena, componentes surgidos das proposições de cada criador, a dramaturgia começou a ganhar corpo. Dessa perspectiva, a afirmação de que, no processo colaborativo, o termômetro para a criação é a proposta concretizada, a cena, se elucida.

\begin{abstract}
Teorias, visões estéticas, impressões, sentimentos, informações, todos esses elementos que são trazidos por atores, diretores, dramaturgos, cenógrafos, figurinistas e outros criadores, para a arena do processo de criação tinham agora referenciais concretos: o espetáculo e o público [...]. A trajetória do processo colaborativo, como de resto em qualquer processo criativo, vai do abstrato ao concreto e do subjetivo ao objetivo, da intuição e do material informe presente no criador até o material objetivo e comunicável [...]. É importante essa trajetória em busca do concreto e do objetivo para que o processo não se dilua no perigoso prazer da discussão intelectual ou na confrontação de impressões e sensações imprecisas. Todo material criativo (idéias, imagens, sensações, conceitos) deve ter expressão na cena. A cena, como unidade concreta do espetáculo, ganha importância fundamental no processo colaborativo ${ }^{20}$.
\end{abstract}

Como se não bastasse trabalhar com princípios de criação colaborativa, os quais pressupõem um posicionamento não só estético, mas também ideológico em relação à própria criação, nós estávamos explorando, ainda, os elementos rapsódicos de que fala Sarrazac (2005: 184), os quais - ao provocar um trânsito entre as diversas matérias textuais, um mosaico dinâmico de formas teatrais e extra-teatrais - propiciavam uma instância de atuação ampla, não aprisionada mais à idéia do personagem.

Nesse sentido, a textura dramatúrgica deixava de ser fiada somente pelas relações e situações ficcionais, vivenciadas em cena, e passava a ser também tecida pelas relações estabelecidas entre o corpo obsceno do espectador e o corpo presença dos atores, constituindo, a partir dos cheiros e das impressões táteis, das aproximações e distâncias, as personas, vozes enunciadoras do discurso cênico. Diferentemente do

\footnotetext{
${ }^{20}$ ABREU, Luiz Alberto de. Processo Colaborativo: relato e reflexões sobre uma experiência de criação. CADERNOS DA ELT, Santo André, v. 1, n. o, mar. 2003, pp. 33-41.
} 
personagem - que constitui uma unidade autônoma em relação ao ator que a interpreta - a persona é constituída pelas diversos níveis de subjetividade que se manifestam em cena, numa espécie de mis-en-scène produzida pelo ator a partir das múltiplas hipóteses de atuação com as quais ele joga. É nesse sentido que o material atoral é pensado como fio condutor para a cena: esse traço, o engajamento do sujeito criador, aproxima a experiência dos criadores da matéria criada e, talvez por isso, seja mesmo uma marca da cena contemporânea ${ }^{21}$. Em consequência, pode-se dizer que o texto acaba por ser composto, ele também, em camadas ou em uma simultaneidade de planos. Território obsceno por excelência, a dramaturgia, dentro do processo de criação colaborativa, é operada em uma dimensão polifônica e múltipla.

Essa polifonia, sem dúvida alguma presente no modo de criação e nas relações que ocorrem em sala de ensaio, no embate das vozes criadoras, está presente também no próprio jogo de construção dramatúrgica e no espaço do texto. É o que denota o termo autor-espectador, cunhado por Rewald (2005) para se referir ao trabalho de escritura realizado pelo dramaturgo nesses processos. Segundo Willemart ${ }^{22}$, na criação literária, em geral, o processo de escritura é constituído pelo diálogo entre duas entidades distintas, presentes no autor: o autor-scriptor e o autor-leitor. Por meio do jogo que instauram entre si, o autor-scriptor produz o texto que é, em seguida, apreciado e criticado pelo autor-leitor. O autor-scriptor vai, então, reelaborar o texto a partir das críticas levantadas. Já no processo de criação colaborativa, surge uma terceira entidade, o autor-espectador que, segundo Rewald, vai constituir seu processo de escritura a partir das mediações feitas em cena por atores e encenador.

O autor-espectador é o escritor forçado a sair de seu gabinete, de sua clausura, de sua solidão imaculada. Para criar ele necessita olhar o outro, entender a criação do outro, dialogar com o outro, aceitar as regras do outro e fazer com que o outro aceite as suas. O autor-espectador tem de olhar para si e para o mundo ao mesmo tempo, e sua criação é a própria medida deste se colocar no mundo. Ele não pode se anular, aceitando totalmente as questões do outro em detrimento das suas, como também não pode impor a qualquer custo as suas idéias, sem ouvir o outro. Em

\footnotetext{
${ }^{21}$ RYNGAERT, Jean Pierre. Ler o teatro contemporâneo. São Paulo: Martins Fontes, 1997.

${ }^{22}$ WILLEMART, Philippe. Universo da criação literária. São Paulo: Edusp, 1993, p. 67.
} 
ambos os casos o processo se empobrece, pois perde a dimensão do diálogo, da interação, necessários para sua evolução (REWALD, 2005: 63).

De modo diverso do processo de escritura de uma "dramaturgia de gabinete", em que a leitura realizada pelo autor-leitor é de um texto escrito que ainda não foi encenado, no processo de criação colaborativa o autor-espectador, a partir das observações feitas ao longo dos ensaios, "tem a possibilidade de criticar os seus 'colegas' antecessores (escritor e leitor) e, em função de tais críticas, propor uma reescritura ${ }^{23}$. Segundo Rewald (2005: 63), nesse processo, o autor-espectador "não vislumbra apenas 'defeitos' do texto, mas também novas idéias e possibilidades [...] que podem ser incorporadas" à dramaturgia. Nesse sentido, a entidade autor-espectador, dentro do processo de escritura, "permite ao dramaturgo escrever e reescrever a peça à medida que ela vai sendo construída como corpo presente, encenada”.

A partir das improvisações e personas propostas pelos atores - Maldoror, Guarda e Deus para Lenine; Atriz e Laurinda para Lissandra - eu havia desenvolvido três núcleos de ação, centrados na idéia da visita: o primeiro, o mais desenvolvido, era a relação do guarda de um manicômio com uma interna. O segundo, a visita de uma atriz a um homem que se dizia Deus. O terceiro funcionava como uma espécie de plano metafórico e era constituído por delírios - erigidos a partir de trechos da obra de Lautréamont - em que a interna era visitada por anjos. Em razão da enorme profusão de material bruto que eu tinha nas mãos e do pouco tempo que tínhamos para aprofundá-lo - de setembro a novembro, quando estava prevista a estréia - optei por desenvolver o núcleo do guarda e da interna e colocar o material textual dos outros núcleos em diálogo com ele.

Desse modo, os personagens de Casa das Misericórdias acabaram por guardar, em sua composição, fortes referências das ações e dos materiais textuais produzidos nos outros núcleos de ação. O guarda João de Deus, por exemplo, tinha muitas de suas ações calcadas em ações do Homem-Deus, personagem que o ator Lenine Martins experimentara anteriormente. Era o caso dos momentos em que João de Deus defecava em cena e que eram, nas improvisações passadas, relacionadas à criação do mundo. Em Casa das Misericórdias, pelo contrário, tais ações simbolizavam, no lugar da potência

\footnotetext{
${ }^{23}$ Ibidem.
} 
criadora, a incapacidade do Guarda de lidar com o próprio desejo sexual. Já Laurinda conservava não só os delírios, originados no plano metafórico do terceiro núcleo, mas, principalmente, a potência feminina que tivera origem na deusa e que marcava sua forma de resistência aos tormentos impostos, em nome da religião, pelo Guarda.

A partir dos tormentos que Laurinda sofria, foi estabelecida, como proposta estrutural da dramaturgia, uma Via Crucis para ela, que se desenrolava em um único dia. Ainda em setembro, após a visita de Abreu que questionou essa unidade de tempo da dramaturgia, resolvemos testar a dilatação temporal da Via Crucis. Como já estávamos trabalhando, a partir das narrativas, a simultaneidade de planos por meio da construção de espaços subjetivos ligados à dimensão da memória e do delírio, optamos por realizar a dilatação temporal não em ordem cronológica ou em uma linha de ação dramática, mas a partir dos espaços que se apresentavam em cena: o cubículo no qual Laurinda estava encerrada, o quartinho onde o Guarda morava, o boteco em que ele se embebedava antes de ir para o trabalho, o pátio no qual ocorria o estupro e os espaços produzidos pelos delírios de Laurinda.

\footnotetext{
O espaço tornou-se arquitetura viva, espaço performático, capaz de transformar a si mesmo e aos objetos e pessoas nele inseridas. (...) $\mathrm{O}$ confronto dessas experiências individuais é o procedimento de criação e de colaboração entre as pessoas; a produção do significado depende de uma reinvenção a partir da interação dos espaços individuais existentes. A cenografia nesse âmbito da ação não se esgota na representação ou na imitação do mundo visível, ao contrário, realiza-se em um processo dialético entre a experiência real e o imaginário (LINKE, 2008: 26).
}

Por meio da marcação que fazia das horas e tarefas, o Guarda era responsável pela ordem dos acontecimentos e pelo desenvolvimento dos tormentos que compunham a trajetória de Laurinda. Estes iam do jejum, imposto no início do espetáculo, ao estupro, que marcava o passo final. Casa das Misericórdias acabou discutindo as tentativas do guarda João de Deus de normalizar Laurinda - a última interna de um manicômio judiciário feminino - e o massacre masculino que, em nome dessa normalidade, ele exercia sobre ela. Mas falava, principalmente, da resistência de 
Laurinda - que, ao desviar-se da norma, era considerada louca - e das impossibilidades de captura, de conformação, que ela tecia.

GUARDA - (...) Então eu ele os ensinou dizendo...

(simultâneas)

LAURINDA - Grande Pau que estais

GUARDA - Pai Nosso que estais no no céu! Venha a nós com vossa céu, santificado seja vosso nome... porra!

O Guarda bem sabe que Laurinda

Penetrai todas as mulheres provoca! É o seu exercício diário.

benditas que eu tiver escrito $o$ Todos os dias, o Guarda faz um nome! esforço sobre humano para não invadir a cela dessa puta, louca, piranha.

LAURINDA - Laurinda era doida, não era? Se isso dava ao guarda direito de fazer o que quisesse, por que não daria a ela?

GUARDA - O Guarda respira fundo e continua...

\section{(simultâneas)}

Venha a nós o vosso reino, seja feita a vossa vontade assim na terra como LAURINDA - Ai, meus anjos no céu. $\mathrm{O}$ pão nosso de cada dia me caralhudos! Os anjos são sete, dai hoje... Peça, Laurinda! Peça! São grandes, de espadas Mas primeiro, meu Pai, perdoa as flamejantes rasgando a Bendita minha ofensa, assim como tenho Buceta de Laurinda! perdoado a quem me tem ofendido... A tentação de Laurinda era a fé Vê? Laurinda continua pelada... do Guarda...

Apesar de todas as roupas que ele eu o Guarda dava pra ela, Laurinda Ave, Laurinda. continua pelada, tentando Cheia de racha. João de Deus, meu Pai... Não deixa... Bendita sois vós entre as Não me deixe cair nessa tentação, mulheres: peitudas meu Pai... mas me livra de todo mal. Bundudas Amém. Bucetudas! 
LAURINDA - Laurinda acaricia a Bendita... "O meu pão de cada dia, me dá hoje, Guarda Belo!...

GUARDA - Pois nem só de pão vive o homem, mas sim de toda palavra que sai da boca de Deus!

LAURINDA - O senhor é Deus? $?^{24}$

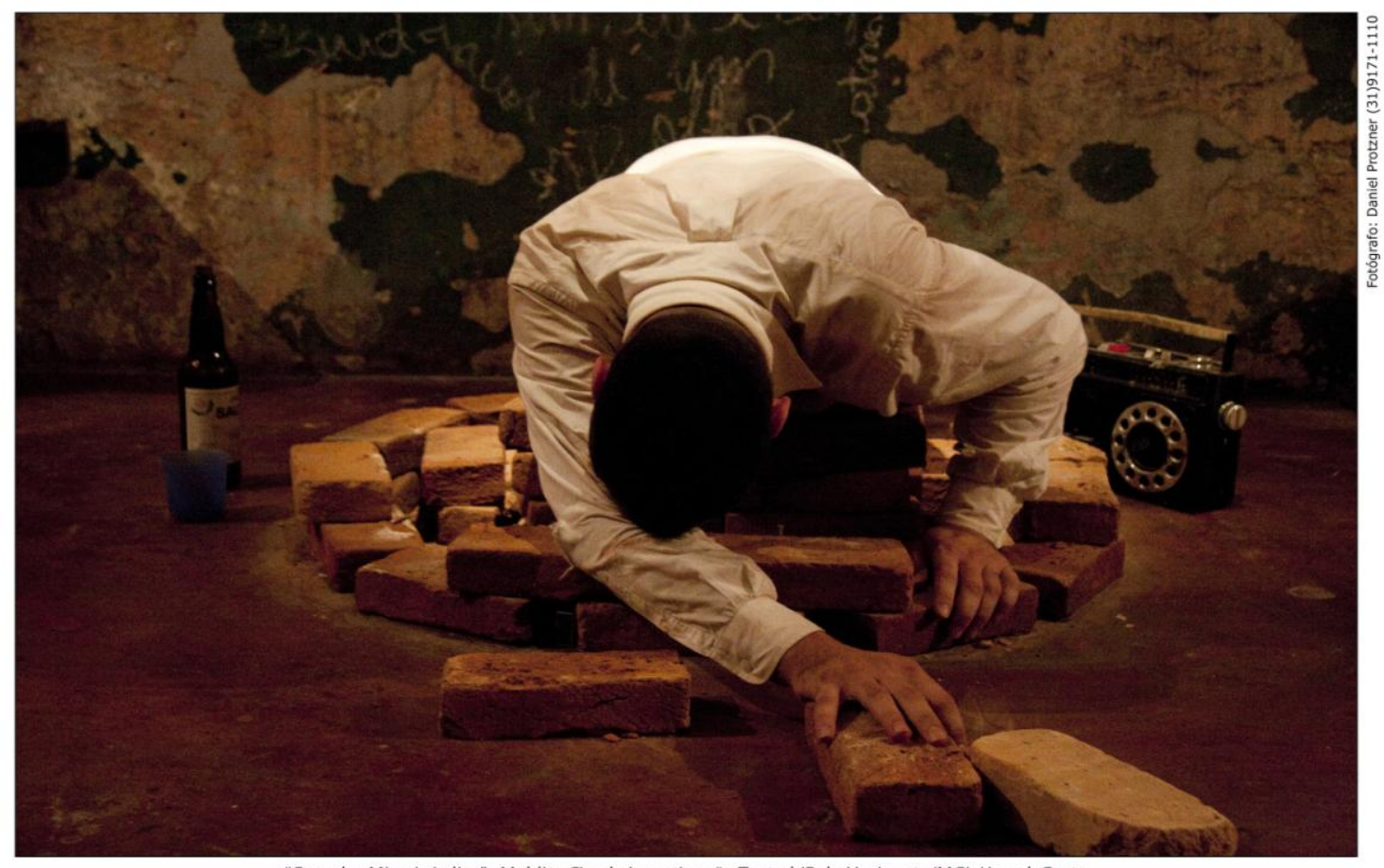

"Casa das Misericórdias" - Maldita Cia. de Investigaçăo Teatral (Belo Horizonte/MG) / Local: Gruta

FIG. 02

Ao abrirmos espaço, na tessitura da dramaturgia, para as várias vozes que compunham as personas - a voz do ator que as encarnava, mas também as vozes sociais que elas representavam e as vozes dos fantasmas que as habitavam possibilitamos que elas emergissem na superfície do próprio texto, como um traço de coralidade dentro da textura rapsódica. Como salienta Sarrazac, a coralidade permite "refletir, seja um sujeito dividido em múltiplas realidades irredutíveis, seja uma realidade exterior ao sujeito, mas percebida por ele como plural ${ }^{25}$. Nesse sentido, a forma coral possibilitaria a criação de "um acúmulo de efeitos convergentes que visam

\footnotetext{
${ }^{24}$ CAETANO, op. cit.

${ }^{25}$ SARRAZAC, Jean Pierre. Choeur/Choralité IN: Lexique du drame modern et contemporain. Belval: Les éditions Circé, 2005, p. 41. Tradução minha do original, em francês: "le choeur peut refléter soit un sujet divisé en plusieurs réalités irréductibles, soit une réalité extérieure au sujet mais perçue par lui comme plurielle".
} 
modificar a relação do espectador com a estrutura fabular da dramaturgia ${ }^{26 ”}$, uma vez que ela vai privilegiar tanto o estilhaçamento do discurso como a eclosão de uma fala lírica no interior do texto teatral (SARRAZAC, 2005: 42). Em Casa das Misericóridas, é justamente essa coralidade que vai dar voz às questões sobre normalidade e loucura, por meio das contradições presentes em João de Deus, mas, principalmente, em Laurinda: Laurinda sofredora do ver, Laurinda lúcida, Laurinda atriz e espectadora de si mesma. Na textura rapsódica entrelaçava-se até mesmo a voz de Maura Lopes, que se fazia presente por meio das palavras inscritas no espaço pela mão e voz da atriz ${ }^{27}$.

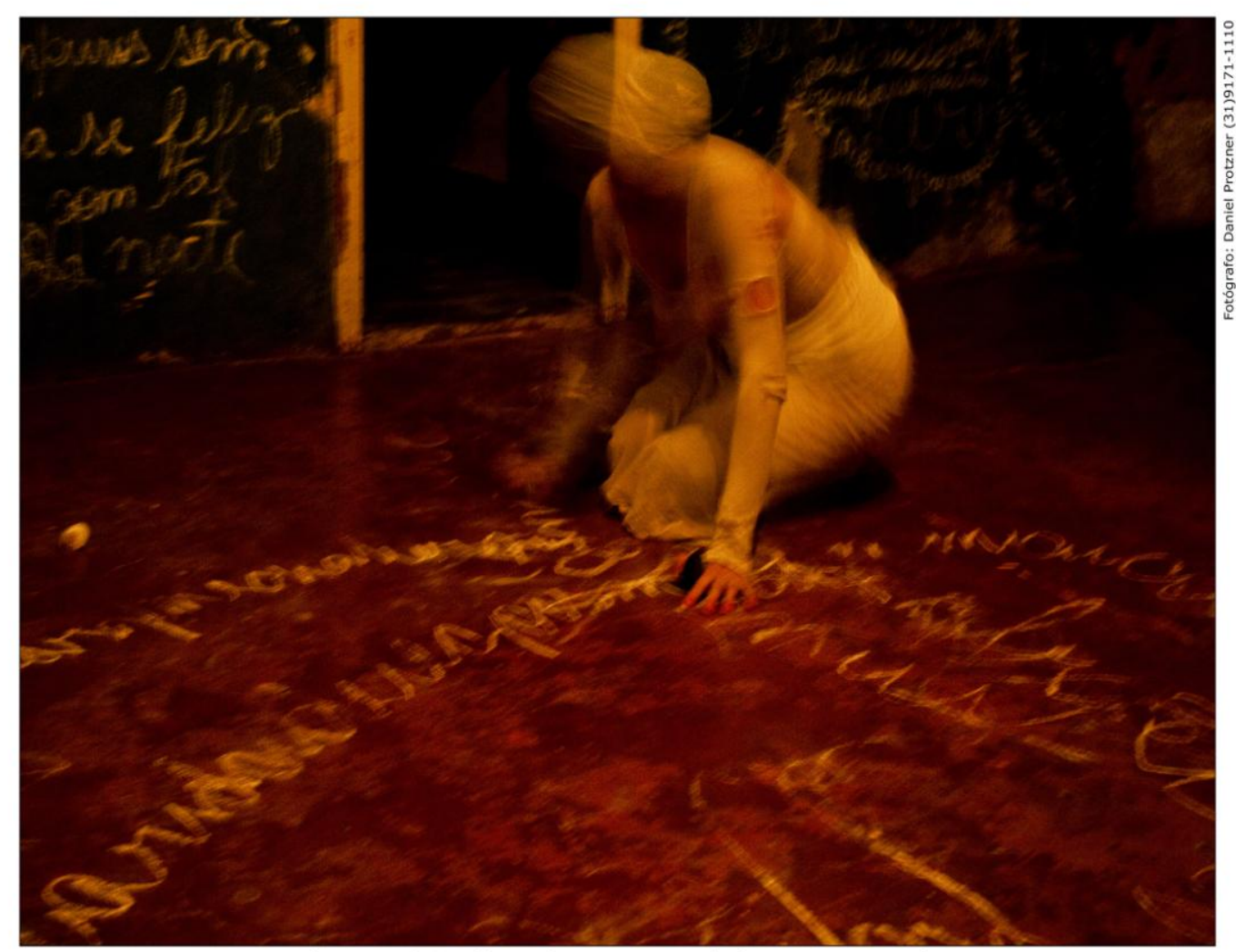

"Casa das Misericórdias" - Maldita Cia. de Investigaçăo Teatral (Belo Horizonte/MG) / Local: Gruta FIG. 03

Laurinda começa um trabalho de escrita nas paredes. Aos poucos, a escrita vira texto em sua boca.

LAURINDA - Ninguém sabia, mas ali, naquele cubículo, Laurinda prepara um livro. Sua vida. A solidão branca dos corredores. A solidão

\footnotetext{
${ }^{26}$ Ibidem: 41. Tradução minha do original, em francês: "des faisceaux d'effets convergents visant à modifier le rapport du spectateur à la fable".

${ }^{27}$ No trecho exemplar, as passagens grifadas são apropriações intertextuais da obra O hospício é Deus, de Maura Lopes Cançado.
} 
branca de sua carne que ninguém toca. Ninguém ama. Quando Laurinda era criança, Laurinda era má. Por isso seu pai tinha colocado ela ali, naquela casa de doidos. Pra ficar de castigo... Seu pai gostava de marrom. Laurinda pensava colorido: as mulheres eram vacas amarelas. Laurinda é quase sempre neutra. Branco. $\underline{O}$ hospício é branco. Branco como ela. Quando era criança pensava que Deus era um olho vigilante. Deus vê tudo. Laurinda é má. Deus castiga. Laurinda escreve. Deus foi o demônio de minha infância. Cheiro de fezes, urina. Comida com bicho, podre. Ratos que passeiam à noite. Moscas bóiam nos copos de café. $\underline{\text { O hospício }}$ é deus.

Laurinda esbarra na porta. Escorrega até o chão e começa a escrever freneticamente. ${ }^{28}$

Contudo, para além da coralidade que era instaurada no plano ficcional, a textura rapsódica também era constituída por uma tessitura polifônica de planos escriturais distintos e simultâneos, entre os quais destaco a espacialização de textos. Manipuladas pela atriz Lissandra Guimarães, tanto na preparação cenográfica do espaço ocupado, como nas ações que realizava durante a apresentação do espetáculo, as escritas que cobriam as paredes e o chão da Gruta - e que constituíam o "livro" de Laurinda - possibilitavam ao espectador a construção de múltiplas significâncias.

À medida que o processo de criação avançava, era possível perceber como a metodologia colaborativa, ao propiciar a investigação de procedimentos que permitiam à dramaturgia nascer "do embate corpo-a-corpo na sala de ensaio" (ARAÚJO, 2002), da relação direta entre as diversas funções responsáveis pela criação, funcionava como fonte geradora de uma dramaturgia própria no interior dos coletivos teatrais, de uma dramaturgia que era, em certo sentido, marcada por sua trajetória processual. Para além da multiplicidade apontada por Rewald (2005), presente no trabalho específico do dramaturgo-espectador, é necessário considerar - quando se pensa o texto como produção polifônica - um elemento importantíssimo nesses processos: o dialogismo.

Polifônico por excelência, o processo colaborativo lida com o diálogo que ocorre não só entre as funções artísticas presentes na criação - que foram, no caso da Maldita, dramaturgia, atuação, direção, cenografia e sonoplastia - mas também com o diálogo

\footnotetext{
${ }^{28}$ CAETANO, op. cit.
} 
operado por essas funções na relação com os espaços de observação e crítica, externos ao processo de criação. Tais espaços eram garantidos, no projeto Cena 3x4, pela presença dos orientadores e dos participantes dos demais núcleos de criação, espectadores especializados que contribuíram para a evolução da obra a partir da observação do material cênico apresentado a eles nas diversas dinâmicas de relação que constituíam o projeto. Evidentemente, essa contribuição era mútua. Ou seja, não somente a nossa dramaturgia - erigida inicialmente a partir da criação colaborativa dos artistas da cena - era alterada em função desse olhar, externo ao processo, como também o diálogo ativo junto a outros processos de criação, vivenciado pelos observadores pertencentes aos outros núcleos do Cena $3 \times 4$, alterava os seus modos de produção e, por conseqüência, as dramaturgias resultantes desses mesmos processos produtivos.

Nesse sentido, é possível afirmar, na esteira de Walter Benjamin, que o trabalho realizado pelo criador contemporâneo não visa somente a "fabricação exclusiva de produtos, mas sempre, ao mesmo tempo, a dos meios de produção ${ }^{29 ”}$. Para Benjamin (1986: 132), o caráter modelar da produção artística é imprescindível à própria arte, cabendo ao artista não somente produzi-la, mas, sobretudo, "orientar outros produtores em sua produção". A conseqüência evidente do trabalho que é realizado pelo criador no diálogo com outros artistas é, segundo ele, a condução de mais "consumidores à esfera de produção", ou seja, a transformação de leitores ou espectadores em colaboradores. A partir dessa perspectiva, a obra resultante ganha o estatuto de arte do espectador, na medida em que ela cria condições "para uma produção radicalmente autoral do espectador, que passa a produzir variados elementos de significação, justapondo-os àqueles propostos ${ }^{30 ”}$ pela obra. Afirma Abreu:

Arte teatral, dentro desse conceito, não é apenas expressão do artista (qualquer que seja ela), mas uma complexa relação entre a expressão do artista e o público. A essa concepção parecem estranhas tanto as definições do teatro como a arte do ator quanto texto dramatúrgico ou geometria cênica. É claro que o eixo principal de um espetáculo pode ser

\footnotetext{
29 BENJAMIN, Walter. O autor como produtor IN: Magia e técnica, arte e política: ensaios sobre literatura e história da cultura. Rio de Janeiro: Brasiliense, 1986, p. 131.

$3^{30}$ DESGRANGES, 2008: 17 (ver nota 64, do capítulo 1).
} 
o dramaturgo, o diretor, o ator, o cenógrafo ou outro criador, mas nenhum deles, isoladamente, define a totalidade do fenômeno teatral, que permanece por sua própria história e maneira de ser uma arte coletiva feita para ser partilhada por um outro coletivo, o público. ${ }^{31}$

Ainda segundo Abreu, o público é responsável, também, por trazer o "pulso da contemporaneidade" ao artista. Para ele, o espectador serve de fio condutor para o universo de sua própria cultura, no interior da qual o artista está mergulhado: “a cultura, o tempo e o espaço histórico tornam-se lastro do fazer artístico, o que contribui para evitar o mero formalismo, comum em processos artísticos afastados do contexto cultural ${ }^{32 "}$.

Discutindo referências de nossa cultura cristã, o espetáculo Casa das Misericórdias buscava problematizar o lugar do público que era, durante toda a encenação, convocado em diversas dimensões. O espectador tinha seus sentidos aguçados cinestesicamente: por cheiros, pela cachaça oferecida a ele pelo Guarda, pelas aproximações corpóreas dos atores. Muitas vezes a proximidade física com determinado ator, ou a visão mais privilegiada de outro acabava por construir novos pontos de vista sobre a cena. De seu espaço restrito - o banco de madeira no qual era instalado, pelo Guarda, ainda no início do espetáculo e do qual não podia sair - o espectador tinha visões parciais, fragmentadas, dos eventos apresentados. Também da perspectiva crítica, o público era solicitado: argumentos eram colocados para ele que, como interlocutor privilegiado de João de Deus e Laurinda - mas também dos atores que, à maneira épica, revelavam a alma e o corpo dos personagens - o espectador era convidado a tomar partido.

GUARDA (para espectador) - Vê como ela fala com João de Deus?

(para Laurinda) Eu tô aqui pra lhe fazer o bem e você me trata assim?

LAURINDA - Filho da puta!

\footnotetext{
${ }^{31} \mathrm{ABREU}$, Luiz Alberto de. Processo Colaborativo: relato e reflexões sobre uma experiência de criação. CADERNOS DA ELT, Santo André, v. 1, n. o, mar. 2003, p. 38.

${ }^{32}$ Idem.
} 
GUARDA - Olha a língua, Laurinda. (para espectador) Eu não disse agora a pouco que ela era uma perdida, uma meretriz, uma assassina de criança? (para Laurinda) Foi por isso que sua família te largou aqui ${ }^{33}$.

Após a primeira experiência de criação dentro do projeto Cena 3×4, a Maldita continuou sua investigação em dois eixos: um estava alicerçado no acompanhamento que seus integrantes, como coordenadores do projeto, faziam dos processos de criação que foram desenvolvidos nos dois anos seguintes. Tal acompanhamento estava relacionado ao estudo do formato do Cena $3 \times 4$ como um todo e, nesse sentido, à discussão dos princípios orientadores do projeto, mas também envolvia a discussão de aspectos relativos às funções criativas específicas e às estratégias de horizontalização na criação, ou seja, ao que posso chamar, utilizando as palavras de Benjamin, de função organizadora dos meios de produção.

Por outro lado, a companhia deu continuidade, nos anos que se seguiram, à investigação de uma dramaturgia do espaço e de uma obra em processo a partir da ocupação de outros espaços não convencionais pelo espetáculo Casa das Misericórdias, de espaços que continham uma especificidade: lugares hoje abandonados, mas que tiveram, no passado, importância para a comunidade, trazendo memória e uma forte significação, como cadeias públicas e asilos para velhos.

Cada novo espaço oferece múltiplas possibilidades e potencializa novas relações. [...] Mais do que criar uma instalação autônoma, cada montagem em um novo local se apropria e habita o lugar. [...] No deslocamento da peça para outros lugares, procura-se estabelecer uma relação sítio específico que dialoga com a proposta ambiental na qual o espectador é inserido. A apropriação de elementos existentes em cada espaço e a sua disposição interferem na relação entre as coisas e na percepção do espectador. [...] A peça procura [...] criar uma situação, na qual os atores e espectadores se instalam num espaço que tem memória passada, e estabelecer um lugar performático com novas referências que questionam as certezas e deslocam as verdades (LINKE, 2008: 28).

${ }^{33}$ CAETANO, op. cit. 
Muitos dos elementos concretos, físicos, pertencentes a esses lugares foram, inclusive, incorporados à obra. Na cadeia pública de Diamantina ${ }^{34}$, por exemplo, havia, nas paredes, diversos escritos deixados pelos detentos que foram, posteriormente, apropriados pela dramaturgia e incorporados aos textos que a atriz Lissandra Guimarães imprimia nos espaços ocupados, tanto na qualidade de elemento cenográfico como na qualidade do "livro" que era preparado por sua persona, Laurinda (ela também prisioneira de uma instituição). Além disso, muitos dos ganhos técnicos - como alterações e definição do desenho da luz, produzidas em função dessas ocupações - também foram integrados ao espetáculo, bem como as modificações nas partituras atorais advindas do exercício de apropriação de novos espaços. Tais elementos acabaram por alterar a textura dramatúrgica de Casa das Misericórdias. Como uma dramaturgia produzida em processo - fruto de uma dimensão coletiva e ligada intrinsecamente à cena - sua escritura renovava-se incessantemente, pois, nela, a ambigüidade, a pluralidade e a subjetividade encontravam espaço propício para se desenvolverem e, com isso, se lançarem em direção ao próprio texto. Nesse movimento processual de constante reescritura, as palavras foram ferramentas imprescindíveis, "porque o texto é o próprio aflorar da língua (...). Não pela mensagem de que ela é instrumento, mas pelo jogo de palavras de que ela é o teatro" (Barthes, 1996: 17).

\subsection{Solo polifônico, textura pós-dramática em Cara Preta}

A investigação processual que realizávamos com Casa das Misericórdias, bem como a percepção de que nossa participação na coordenação do projeto Cena 3x4 se vinculava, intrinsecamente, a um interesse concreto de aprofundar nossos diálogos criativos com outros artistas e coletivos teatrais, por meio da realização de processos efetivos de criação - e não do desenvolvimento de uma perspectiva teórica, externa à sala de ensaio - acirrou o desejo de uma nova montagem. Resolvemos, então, convidar alguns criadores com os quais tínhamos afinidades artísticas para se juntar à nossa

\footnotetext{
${ }^{34}$ Hoje abandonado, o prédio foi, antes de ser cadeia, o Teatro Santa Isabel.
} 
equipe de criação. No novo processo, Lenine Martins - que havia, na montagem anterior, abandonado a direção para assumir a atuação - seria responsável pela direção e Amaury Borges (diretor de Casa das Misericórdias) atuaria ao lado de Lissandra Guimarães e de dois atores convidados, Júlia Guimarães e Cristiano Bacelar. Para compartilhar comigo a dramaturgia, eu havia convidado a atriz e dramaturga Letícia Andrade e, como Ricardo Garcia havia se retirado da companhia, chamamos, para a criação sonora, o músico Rodrigo Rodarte. Ines Linke permanecia no comando da cenografia.

Assim, em 2005, demos início, já com nova composição, a uma pesquisa temática que, ainda pautada na discussão entre indivíduo e instituição, tinha como mote principal o crime. Além da questão temática, era nosso desejo aproximar o espectador mais diretamente do processo de criação do espetáculo e, durante dois anos, a equipe de criação se lançou na construção de uma profusão de materiais cênicos a partir das relações entre o criminoso e a instituição prisional. Materiais que eram, periodicamente, abertos à visitação de públicos diversos, que iam de amigos e artistas a pessoas da comunidade. Além disso, muitas das nossas improvisações eram desenvolvidas diretamente na rua, em contato direto com o transeunte.

Contudo, apesar da intensa produção, os materiais cênicos não chegavam nunca a uma definição que permitisse aprofundá-los dramaturgicamente. Por mais que fossem produzidas matrizes textuais, parecia haver certa resistência em dar forma ao material, em ordenar o caos no qual estávamos mergulhados. Aliados a essa resistência, outros fatores contribuíram para que o processo criativo se alongasse de maneira desnecessária e pouco profícua: a falta de verba para a montagem, além do excesso de compromissos alheios à Maldita por parte da equipe de criação são exemplos. Além disso, questões de ordem interna, como a falta de objetividade em relação aos nossos desejos e rumos na criação, bem como jogos de poder e dificuldades de compartilhamento, geraram uma verdadeira "dança das cadeiras", com entrada e saída de vários artistas da companhia e mudanças de função: após "pular" da dramaturgia para a atuação, Letícia Andrade abandonou o processo, bem como Rodrigo Rodarte; saíram Cristiano Bacelar e Júlia Guimarães e entraram os atores Admar Fernandes e Joyce Malta; Amaury, que iniciara como ator, acabou assumindo a iluminação e, em seguida, a direção e Lenine, antes na direção, passou para a atuação. 
É exemplar dessa "dança das cadeiras" o processo ocorrido no campo da dramaturgia. Como dramaturga, o meu interesse era investigar, por meio da exploração da memória e da fratura da linha temporal, a criação de uma textualidade que permitisse colocar em confronto pontos de vista diversos e brincar com os limites entre a ficção e a realidade. Com essa finalidade, elegi como base para minha investigação textual - e o conseqüente desenvolvimento de proposições dramatúrgicas e sugestões de improvisação atoral - materiais documentais, tais como notícias de jornal e autos judiciais, que possuíssem mais de uma "versão" sobre o mesmo fato. À Letícia Andrade interessava, sobretudo, pesquisar os mecanismos épico-dramáticos que nós, da Maldita, já vínhamos desenvolvendo desde o processo anterior. Desse modo, ela poderia se apropriar desses instrumentos e equalizar nossas experiências de criação. Após alguns meses de trabalho, Letícia - insegura em relação ao seu status dentro da companhia - ainda não havia conseguido realizar propostas para a dramaturgia. Resolvi, então, criar, a partir das improvisações desenvolvidas junto aos atores e de alguns contos escritos por ela - narrativas produzidas anteriormente ao processo - estruturas de cena que permitissem inserir os materiais textuais de Letícia no processo de criação e que nos possibilitassem criar um diálogo como co-criadoras. Abaixo, transcrevo, para comparação, o conto Receita de Família e um trecho da cena Ceia de Natal.

Em uma sala de tv, acrescente pai, mãe e dois filhos. Teremos o que podemos chamar de família. Acrescente a gosto cachorro, barata e ratos, que podem morar ou não dentro do sofá.

Misture lentamente ódios antigos, empréstimos indevidos, pequenas mesquinharias e mesma televisão de vinte anos, com a antena quebrada. Objeto de disputa, objeto de desejo de todos na casa.

A seguir reserve mãe na cozinha, filho no banheiro, filha no quarto e pai na garagem para depois juntá-los novamente na hora do jantar. Tudo pronto. Agora congele e vá degustando uma porção a cada dia ${ }^{35}$.

\section{Primeiro momento: a família feliz}

Alguém muda o canal da tv. Música dos Flinstones. Os quatro começam a se movimentar, numa correria, para se ajeitar numa pose familiar típica:

\footnotetext{
${ }^{35}$ ANDRADE, Letícia. Receita de Família IN: Cães Domesticados (inédito. Ver Anexo B.2).
} 
pai sentado ao centro, ladeado pela mulher e filhos. Sorrindo, congelam para a fotografia. O filho se destaca do quadro.

FILHO (apontando para os outros) - Aqui temos uma família feliz! A mãe já fez sua primeira plástica! A irmã já passou no vestibular e o pai, o pai já... ele já...

MÃE (interrompe o filho, tentando disfarçar o momento embaraçoso. Sorri como em uma propaganda de margarina) - Ela tinha os melhores filhos do mundo! Ai, como ela amava os filhos! Vem cá, chuchuco! Abraça a mamãe... (se dirigindo a um espectador) Vai, moço (moça)! Pode tirar a fotografia...

FILHA - Mostra o silicone, mãe! É novo! (para o espectador) A mãe é quem delimita funções na casa: pagar um carnê ou comprar cigarros. Há muito ela perdeu a capacidade de andar sozinha e se agarra aos filhos como quem se agarra a uma tevê. Devo perdoá-la.

FILHO - Vejam essa família feliz! (PAI - Partida!) Essa família (PAI Falida!) pode figurar em qualquer fotografia. Em qualquer propaganda de margarina! Uma família feliz! (PAI - Fingida!).

PAI - Senta aqui, filha! Vamos brincar!

FILHA - Desde pequena que o pai brincava com ela. Upa, upa, cavalinho! PAI - Quer dançar, quer dançar! O tigrão vai te ensinar!

Pai parte para cima da filha, jogando-a no chão. Começa a transar com ela. Em seguida, parte para cima do filho e depois para cima da mãe.

MÃE - Sai, cachorro! Sai! O problema era o cachorro... Será preciso dá-lo, levá-lo, matá-lo?

Pai sobe em banco e coloca os braços em cruz. Os filhos e a mulher começam a jogar sujeira nele, negando-o (imagem de apedrejamento). PAI - O homem, sozinho naquele apartamento, feito um cachorro na noite de Natal se prepara para morrer. (ele se prepara para saltar. Cai no chão. Rasteja.) O problema era o pai: disfarçá-lo? Dá-lo? Matá-lo? ${ }^{36}$

A iniciativa, no lugar de abrir novas possibilidades de diálogo na criação, desencadeou uma crise e Letícia Andrade, descontente com o exercício da função, resolveu abandonar a dramaturgia e assumir a atuação, ao lado de Lissandra

\footnotetext{
${ }^{36}$ CAETANO, Nina. Ceia de Natal (inédito. Ver Anexo B.1). Sublinhados, trechos que foram adaptados de outros contos de Letícia Andrade, também pertencentes à coletânea Cães Domesticados. No conto Iniciação ao Estrangeiro, por exemplo, um dos trechos sublinhados - que, na cena é referente à mãe diz respeito ao pai da narradora: "O pai, mesmo ausente, manda nos meus pensamentos, delimitando funções na casa: pagar um carnê ou comprar cigarros. Perdeu a capacidade de andar sozinho, e não consegue mais largar a tevê" (Letícia Andrade: Iniciação ao Estrangeiro. Ver Anexo B.2).
} 
Guimarães e Cristiano Bacelar (Júlia Guimarães já havia abandonado o processo). Como essa nova configuração, desenvolvemos, durante quase um ano, um rico material cênico que permitiu o levantamento de uma estrutura textual bastante consistente em torno da questão: Onde mora o crime? Com a estrutura levantada, realizamos alguns ensaios abertos para espectadores especializados, entre eles orientadores e participantes do projeto Cena 3x4, como o Grupo Teatro Invertido, Antônio Araújo e Fernando Mencarelli, professor do Curso de Teatro e da PósGraduação em Artes da EBA/UFMG e coordenador pedagógico do Galpão Cine Horto. O intuito era discutir o funcionamento de alguns espaços abertos à improvisação e a uma maior inserção do público dentro da textura dramatúrgica.

Apesar da potência do material levantado, as crises nas relações pessoais logo tornaram impossível o diálogo artístico entre os integrantes do núcleo fundador da Maldita, em pleno processo de dissolução de seus casamentos ${ }^{37}$. Foram feitas algumas tentativas de dar continuidade ao processo de criação, mas, por fim, absolutamente insatisfeitas com o modo como o trabalho criativo vinha se desenvolvendo, em novembro de 2007 Lissandra Guimarães e eu nos retiramos da companhia e assumimos a coordenação do Obscena ${ }^{38}$, agrupamento independente de pesquisa cênica que havíamos fundado, no início daquele ano, como um grupo de estudos teóricos e práticos sobre a cena contemporânea e no qual estávamos conseguindo aprofundar, de fato, nossas questões como artistas.

Desgastada pelo longo processo e pelas sucessivas alterações na equipe de criação, a Maldita resolveu investir no material atoral desenvolvido por Lenine Martins e partiu para a construção daquilo que, mais tarde, seria denominado, por seus criadores, como um "solo polifônico": uma dramaturgia que permitia ao ator transitar por diversas personas por meio das relações travadas com o espaço e com os objetos manipulados em cena. Para dar seguimento à experiência iniciada, a companhia chamou, novamente, Letícia Andrade (para assinar a dramaturgia) e Ricardo Garcia (para assumir, junto com Admar Fernandes, a criação sonora), além dos iluminadores Felipe Cosse e Juliano Coelho.

\footnotetext{
${ }^{37} \mathrm{O}$ núcleo original era composto por dois casais: Lissandra Guimarães e Amaury Borges, Lenine Martins e eu.

${ }^{38} \mathrm{O}$ trabalho desenvolvido pelo Obscena é objeto de estudo da presente tese (ver o capítulo 4).
} 
O processo resultou no espetáculo Cara Preta, que estreou em 2009 e não somente deu continuidade, mas também verticalizou a investigação da Maldita em torno de uma dramaturgia do espaço e da participação do espectador na construção da textura cênica ${ }^{39}$. De maneira semelhante ao espetáculo Casa das Misericórdias, a dramaturgia foi urdida na interação com um lugar específico, a Gruta e - como neste foi experimentada na ocupação de outros espaços. São exemplares a ocupação da sede do Grupo Resid[ê]ncia, em Ouro Preto (2009) e do antigo cinema do bairro Santa Tereza, em Belo Horizonte, durante a $10^{\underline{a}}$ edição do Festival Internacional de Teatro Palco e Rua (2010). No entanto, de modo diverso do processo de criação anterior, na feitura de Cara Preta a presença do espectador contribuiu diretamente para a configuração do material cênico. Como afirma o ator Lenine Martins ${ }^{40}$, após três meses de ensaios, foi levantada uma estrutura dramatúrgica que permitiu ao trabalho começar a "dialogar abertamente com o público", sendo que, a partir dessas apresentações abertas à interferência do espectador, os elementos da pesquisa começaram a ser amadurecidos. Entre os elementos, o ator cita a ocupação do espaço, a narrativa épico-dramática e o mascaramento, definido por ele como a apropriação de objetos - tambores, tecidos, baldes e até barro - que permitem a insurgência de novas instâncias ficcionais.

Luz horizontal na máscara-barril. A luz balança.

Morra! Morra! Morra! Porra!

Acalma-se. Pisa nas tábuas como se entrasse no barraco.

O Boi leva para dentro sua carcaça e arrasta o corpo de Eraldo para fora do barraco.

O melhor barraco das redondezas. Vista ampla. Bem posicionado.

Lá dentro cama com colchão, fogão e televisão. Tudo limpo e ajeitado.

\footnotetext{
39 Segundo informações retiradas do blog da Maldita, o espetáculo Cara Preta aborda, a partir de "retratos sociais, [...] fragmentos de narrativas e lugares que falam da negligência, criminalidade e sobrevivência humana". Nele, a companhia dá continuidade a elementos de sua pesquisa, tais como "a ocupação de espaços, a autoria de uma obra coletiva que afete de maneira sinestésica e reflexiva o espectador e a exploração dos pontos de vistas sobre a cena gerada pelas figuras surgidas do "mascaramento" do ator e da interação com os demais elementos da cena: luz, som, vozes e materialidades espaciais". Acesso em 14/o1/2011: http://cia-maldita.blogspot.com/.

${ }^{40}$ Depoimento realizado durante o making of de Cara Preta. Acesso em 14/o1/2011: http://ciamaldita.blogspot.com/.
} 
O Eraldo agora sou eu. O Eraldo agora sou eu...

Deita exausto. Canção "Boi da cara preta”. Passagem.

\section{$* * *$ \\ Quadro II - O Hermafrodita}

A libélula se prepara. Do barril-casulo, deita. Sai tecido-branco-asa-saia de vual.

Música de primavera, pássaros e assovios.

Ela acorda sussurando... SSSSSSSSSSSSS. Sai sua, serpente sua suada, sugada, suja... SSSSSSSSSSSS.

SAI: viço, vingado, visgo, voraz, vertigem, viaduto, vida viril, viagem, virulento, viado, virgem...

Calma lânguida... sibila, dada, dá...

Arrasta-se pelo chão. Faz círculos. De quatro, levanta peitinhos. Aprontase, arruma-se.

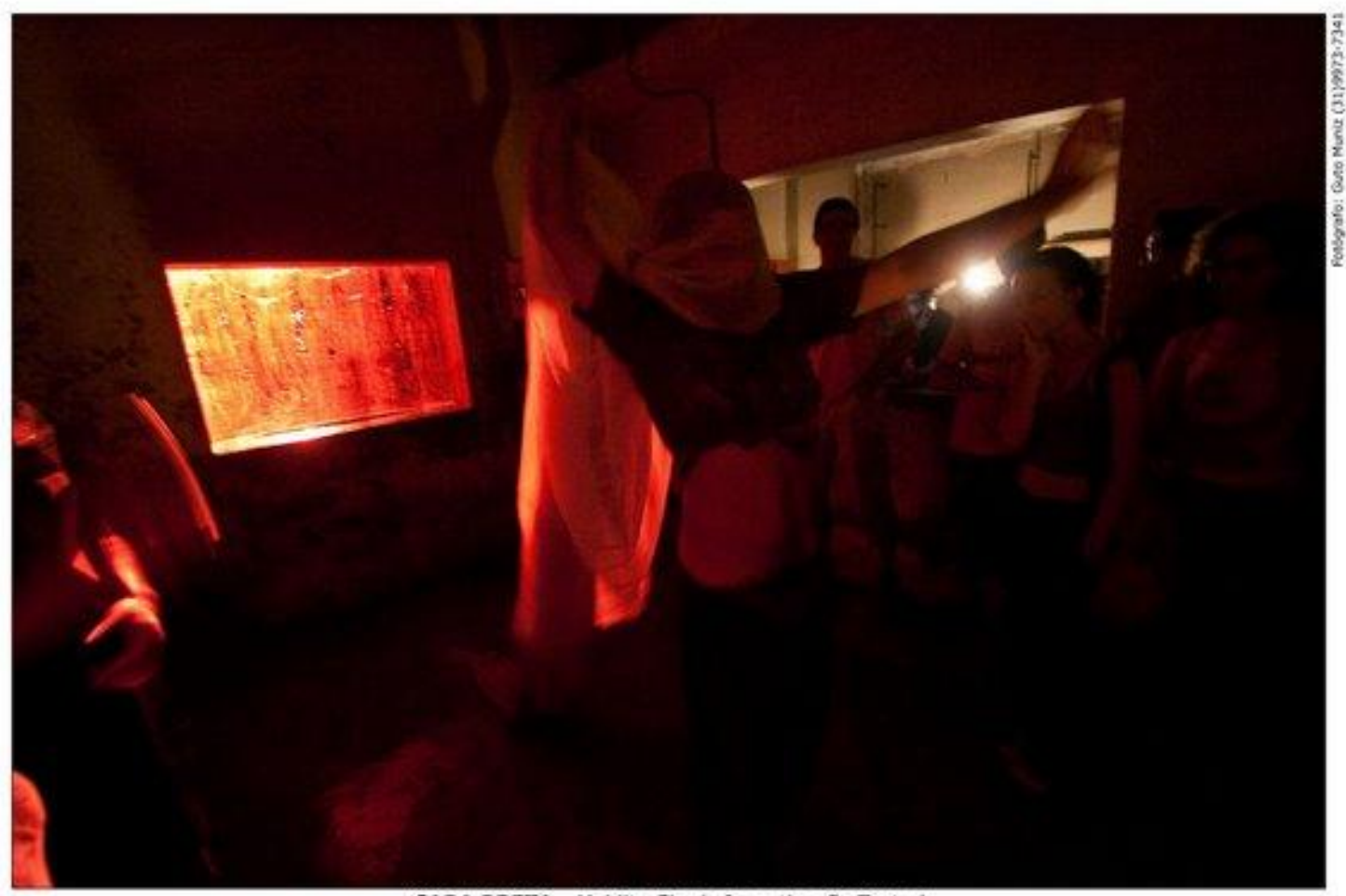

CARA PRETA - Maldita Cla de Investigação Teatral

FIG. 04

O peso do cabelo, loiro, o maldito cabelo dela, nele. Ela tem a noite inteira. Ela, ele, êla se estica, se esparrama, sonha. Com a voz vazada procura seios, maminhas, oleosa serpente que desliza e enraíza pelo chão. 


\section{Mas ela ainda não começou,}

Esqueci de uma coisa...

Ela amarra. Agora precisa da força de homem ${ }^{41}$.

Como resultado do aprofundamento da pesquisa realizada pela Maldita, há, em Cara Preta, uma intensidade maior na apropriação de toda a arquitetura da antiga casa-bar, expressa não só pela itinerância do público e pela "liberdade" com que ele transita pela Gruta, mas também pela fricção entre os elementos materiais da cena e a textura dramatúrgica. Para Luiz Carlos Garrocho ${ }^{42}$, filósofo e estudioso da cena contemporânea, essa intensa fricção é evidenciada pelo deslizamento entre os planos da ficção e da realidade. Segundo ele, no espetáculo não ocorre, em momento algum, uma conversão completa de um plano ao outro, mas é como se houvesse sempre "um vestígio material não incorporado, e que é denunciado, atritado e impregnado aos enunciados". Manipulados pela narrativa de Lenine Martins, "os objetos, os elementos diversos transformam-se aos nossos olhos e, ao mesmo tempo, conservam sua existência”, em um jogo de resistência em relação às imagens produzidas por essa mesma narrativa e pelas ações sonoras e corporais realizadas pelo ator. Nesse sentido, afirma Garrocho, “a cenografia não é montada para ilustrar a encenação: assim, a concretude do espaço não explica a ficção".

Direciona-se para a porta do espaço interno da cozinha. Relaciona-se com o espaço.

A gente já passava pela porta da cobertura e cumprimentava o porteiro.

No espaço interno da cozinha, o ator liga uma luz branca minúscula que ilumina o lugar. O público acompanha o ator.

Pah. Todo mundo calado. No chão. Chegando lá: era uma cobertura de primeira, festa de primeira, canapé, caviar, champagne e whiski, mulherada oxigenada, siliconada, tudo turbinada. Tá todo mundo confortável?

O atuante muda o tom de seu discurso bruscamente.

\footnotetext{
${ }^{41}$ ANDRADE, Letícia. Trecho da dramaturgia de Cara Preta (texto fornecido pelo ator Lenine Martins. Ver Anexo C).

42 GARROCHO, Luiz Carlos. A impregnância do sentido no teatro: Cara Preta. http://www.luizcarlosgarrocho.redezero.org/a-impregnancia-do-sentido-no-teatro-o-cara-preta/ (acessado em 23/09/10).
} 
Então todo mundo bota a mão na cabeça e vai me passando tudo que tiver. Vamo conhecer a casa.

O banheirinho dá hora.

Ele se direciona para o espaço do banheiro interno e para o espaço chamado bar, onde estão o técnico de som, geladeira e fogão. Oferece uma cerveja para o espectador. Depois o trancafia no banheiro.

Hoje é festa. Saúde. Ao ano novo que começa. Peguei a empregada tira os peito para fora.pah-pum. Vamo fazer um jogo. Falei com os meu mano.

Peguei o mais engravatado e pedi dá três passos para trás e então pah! Miolo para todo lado

Pega microfone, voz em eco. Entra no espaço amplo

Cama king-size

Subi na cama e caguei merda pra todo lado, juntei o lençol de seda. E limpei gostoso. Seda é que bom para limpar o cu, papel higiênico é uma merda. Eu que sou o criminoso? Remorso nenhum ${ }^{43}$.

Em Cara Preta, o deslizamento entre os dois planos - o da ficção instaurada e o da realidade concreta do espaço cênico onde o espectador está mergulhado - é fruto, em grande medida, do modo de atuação de Lenine Martins, sendo possível afirmar que o espetáculo é, antes de tudo, um tour de force do ator.

Quando digo que Lenine reinventa para si e para nós o teatro, estou falando de uma experiência singular de tomar as palavras e torná-las algo pesado como o óleo, ou o sangue coagulado. (...) Não há dúvidas de que o texto falado é condutor da ação e que há uma centralidade do ator, mesmo que transformados pelos elementos com que dialogam e que lhes resistem com sua materialidade e imagens que lhe são próprias e inerentes. Mas a narração verbal é um problema corporal, antes de tudo. [...] Essa vocalização é pura impregnação da palavra que fica colada, pela sua viscosidade, na pele do ator e, por proximidade, resvala na nossa. E opera passagens entre a primeira e a terceira pessoa, às vezes narrando o ator o que seu personagem vai fazer. A atuação ou performação manipula

\footnotetext{
${ }^{43}$ ANDRADE, Letícia. Trecho da dramaturgia de Cara Preta (texto fornecido pelo ator Lenine Martins.
} Ver Anexo C). 
sensorialmente os elementos ou por eles é afectada, produzindo os nexos de sentido que o texto narrado provoca ${ }^{44}$.

Como salienta Garrocho, no lugar da significação, o que ocorre em Cara Preta é uma impregnação dos sentidos provocada pela materialidade da linguagem cênica. Ou seja, o espetáculo produz uma atmosfera - a partir justamente dessa impregnação, dessa viscosidade - que permite mergulhar o público em uma experiência teatral que refaz, em sua singularidade, os caminhos do sentido (e dos sentidos) para ele. O público, ao compartilhar com o ator a mesma duração, torna-se ele também, mais que mero espectador, um participante e, como tal, implicado no ato artístico. Aqui, a recepção tátil ${ }^{45}$ da obra se realiza "na própria produção do participante, impingindo-o a uma atuação efetiva, já que [a leitura] passa necessariamente por suas entranhas" (DESGRANGES, 2008: 17). Dessa perspectiva, o espectador se torna, pela dialética que é instalada, efetivamente, um co-autor da cena.

\footnotetext{
${ }^{44}$ GARROCHO, op. cit.

${ }^{45}$ DESGRANGES, 2008: pp. 11-19.
} 
O ser exige de nós criação, para que dele tenhamos experiência.

Merleau-Ponty 


\section{Desdobramentos colaborativos do projeto Cena 3x4. Estudo de caso: Grupo Teatro Invertido}

\subsection{Teatro de grupo: do grupo de pesquisa ao teatro de pesquisa}

É possível notar, dentro do cenário cultural de Belo Horizonte, um aumento significativo do número de coletivos teatrais da cidade: sua proliferação, nos últimos dez anos, é um fenômeno visível. Evidentemente, não é um fenômeno restrito à cena belorizontina nem ao contexto mineiro. Segundo levantamento realizado pela revista Subtexto (GALPÃO CINE HORTO, 2007), por meio de articulistas de diversas regiões do Brasil, o número de grupos de teatro no país chega a três mil. Em igual medida, cresce o interesse e a valorização da produção artística realizada no interior desses coletivos: o surgimento de espaços exclusivamente destinados à criação e circulação da produção, além da manutenção, do chamado "teatro de grupo" em editais de festivais, patrocínios e prêmios do Brasil inteiro basta para comprovar isso.

Segundo Rosyane Trotta, no artigo $^{1}$ em que analisa o mapeamento realizado pela revista, em Minas Gerais o número de grupos é de cerca de 250. O levantamento, como a própria revista Subtexto já havia explicitado², é um tanto precário, tendo sido feito, segundo Trotta (TROTTA, 2008:31), a partir de critérios tão distintos quanto "realizar teatro de pesquisa" ou "organizar-se como agrupação cultural". Ela ressalta que, no estado de Minas Gerais, há um forte movimento teatral capitaneado pelos grupos, o que permite fazer um levantamento a partir de balizas como filiação a movimentos ou entidades representativas, mas mesmo esses parâmetros, a meu ver, seriam imprecisos em relação a um expressivo número de coletivos que não se inserem neles.

Apesar da precariedade do levantamento feito - uma vez que a revista, sem instrumentos de pesquisa mais rigorosos e dados, nesse sentido, mais concretos, pode

\footnotetext{
${ }^{1}$ TROTTA, Rosyane. Grupos de Teatro no Brasil: convergências e divergências IN: Subtexto: Revista de Teatro do Galpão Cine Horto. Belo Horizonte: Edições CPMT, ano V, oㅡ 5, dez 20o8, pp. 31-36.

${ }^{2}$ GALPÃO CINE HORTO. Grupos de Teatro no Brasil: realidade e diversidade IN: Subtexto: Revista de Teatro do Galpão Cine Horto. Belo Horizonte: Edições CPMT, ano IV, oo 4, nov 2007.
} 
somente tecer um panorama algo impreciso, um esboço da realidade dos grupos no Brasil - e deste atender a critérios muito diversos, inclusive do que seriam grupos de teatro, é possível vislumbrar aspectos da arte produzida pelos coletivos de criação cênica. André Carreira, no artigo $^{3}$ que abre a Subtexto n⿳⺈⿴囗十, levanta alguns critérios para orientar essa definição: segundo ele, são características comuns dos grupos de teatro a duração dos projetos e a manutenção de equipes estáveis, o que implica em continuidade do trabalho realizado por essas agrupações. Este, muitas vezes, extrapola o âmbito artístico e atinge o âmbito social, em consonância com aquilo que parece ser mais uma das características dos coletivos: a necessidade de atuar em projetos sociais, principalmente ligados a setores menos privilegiados, e constituir seu espaço político. Além disso, os grupos parecem ser especialmente caracterizados pela busca de um trabalho criativo autônomo, não sujeito às leis de mercado ou da indústria cultural. Essa autonomia na criação está, muitas vezes, associado ao que é comumente conhecido como teatro de pesquisa.

Desse ponto de vista é possível associar a proliferação de coletivos teatrais que vem ocorrendo em Belo Horizonte nos últimos anos com alguns fatores que possibilitaram uma maior comunhão, por parte dos artistas da cidade, entre pesquisa e criação. Um bom exemplo talvez seja a consolidação de importantes encontros e festivais na área de artes cênicas - como o Encontro Mundial das Artes Cênicas (ECUM), o Festival Internacional de Teatro Palco e Rua de BH, o Festival Internacional de Teatro de Bonecos, o Festival Internacional de Dança, a Manifestação Internacional da Performance e o Festival Mundial de Circo - que têm proporcionado acesso não só a novas linguagens, por meio da apresentação de espetáculos e de outras formas de manifestações culturais, mas também a uma formação prática e a uma dimensão reflexiva do fazer artístico.

Além disso, pode-se citar como fatores influentes no panorama artístico da cidade, a criação de centros culturais, como o Galpão Cine Horto, e a proliferação de sedes descentralizadas de grupos, que têm propiciado não só o surgimento e a consolidação de redes de compartilhamento e diálogos sobre criação e reflexão sobre a arte, mas também a ocupação artística em outras regiões da cidade e o

\footnotetext{
${ }^{3}$ CARREIRA, André. Teatro de Grupo: diversidade e renovação do teatro no Brasil IN: Subtexto: Revista de Teatro do Galpão Cine Horto. Belo Horizonte: Edições CPMT, ano IV, no 4, nov 2007, pp. 8-11.
} 
desenvolvimento de projetos que acabam por gerar novas agrupações. Por fim, é necessário citar, como fator de importância para uma formação profissional voltada para a investigação teórica e prática no campo das artes cênicas, a criação de cursos de graduação - antes inexistentes na região, que só possuía cursos técnicos de formação de atores - como o Curso de Artes Cênicas da UFOP e o Curso de Graduação em Teatro da UFMG.

Foi justamente no interior de um grupo de pesquisa vinculado ao Curso de Teatro da UFMG que surgiu o Grupo Teatro Invertido, fundado, em 2004, pelos atores Rita Maia, Leonardo Lessa e Rogério Araújo, com a finalidade de dar seguimento à investigação sobre treinamento do ator e criação cênica que eles, como integrantes do GRUPA - Grupo de Pesquisa-Prática em Atuação - tinham desenvolvido durante sua permanência na graduação. Coordenado pela professora Bya Braga e fundado por ela e pela então aluna Rita Maia, o GRUPA agregou, em 2002, os também alunos Leonardo Lessa e Rogério Araújo, passando a desenvolver intensas investigações no campo da preparação técnica do ator, as quais resultaram no espetáculo Os Cupins, com direção e dramaturgia de Bya Braga ${ }^{4}$. Em 2003, ainda como GRUPA, eles criaram o espetáculo Nossa Pequena Mahagonny, com direção de Lenine Martins e dramaturgia coletiva baseada no texto Ascensão e Queda da Cidade de Mahagonny, de Bertolt Brecht. No ano seguinte, os atores se retiraram do grupo de pesquisa e fundaram o Grupo Teatro Invertido, incorporando Nossa Pequena Mahagonny ao seu repertório.

Foi nesse trabalho, por meio do diretor Lenine Martins - integrante da Maldita Cia. e coordenador do projeto Cena $3 \times 4$ - que o Teatro Invertido teve seu primeiro contato com a metodologia colaborativa de criação cênica. Havia, por parte dos atores, o desejo de aprofundar a pesquisa em teatro para rua, iniciada no espetáculo Os Cupins, e também de investigar a obra de Brecht, bastante inspiradora para um grupo que estava em busca de construir não apenas seu espaço artístico, mas também uma atuação política. Somou-se a essas aspirações, a proposta, apresentada pelo diretor, de pesquisa de uma dinâmica de criação não hierarquizada que permitisse, por meio de uma maior horizontalidade nas relações criativas, a construção de uma dramaturgia

\footnotetext{
${ }^{4}$ A partir do texto Carta aos Atores, de Valère Novarina.
} 
original, ainda que inspirada em um texto de Brecht. Foram estabelecidos, assim, os eixos que norteariam a montagem.

Como o grupo estava partindo de uma dramaturgia pré-existente, nos primeiros meses de ensaio ele trabalhou somente com uma consultoria dramatúrgica que foi, apesar disso, extremamente importante para o desenvolvimento da criação, pois, dos encontros com Reinaldo Maia - do grupo Folias D’Arte, de São Paulo - surgiu a questão central da dramaturgia do espetáculo. Profundo conhecedor da obra de Brecht, Maia propôs, para a equipe de criação, discussões relacionadas principalmente à atualização política do texto brechtiano, buscando perceber quais seriam suas correspondências contemporâneas. A partir das possíveis correspondências entre os elementos da contemporaneidade e a cidade de Mahagonny desenhada por Brecht, surgiu a idéia de sua transposição midiática para uma Mahagonny representada por uma emissora de televisão.

Tendo a idéia de transposição como eixo, a equipe de criação partiu para as improvisações, a fim de levantar um roteiro de cenas. Contudo, à medida que o processo de criação se desenvolvia sem a participação de um dramaturgo, tornou-se patente, para toda a equipe envolvida, que era necessário assegurar, para a plena realização de uma criação de natureza colaborativa, a manutenção do tripé mínimo composto por atuação, direção e dramaturgia (ARAÚJO, 2002). Durante o processo, o material textual que compunha o roteiro de cenas era registrado pelos próprios atores e diretor - sofrendo alterações a cada ensaio - e apenas os elementos que eram frutos de consenso entre todos os criadores permaneciam como partes da estrutura dramatúrgica. A dramaturgia, justamente por não haver ninguém que respondesse por sua estruturação, tinha chegado a diversos impasses, para os quais a equipe de criação não havia encontrado um denominador comum. Com a necessidade de se ter um ponto de vista mais objetivo sobre o material criativo levantado até então, a equipe de criação convidou, já na fase de conclusão do espetáculo, o escritor Guilherme Lessa para tentar amenizar as arestas da dramaturgia e finalizar o texto criado para a peça. Lessa havia participado da primeira edição do projeto Cena $3 \times 4$, na qual havia sido responsável pela dramaturgia do espetáculo Nesta Data Querida, desenvolvido pelo núcleo Luna Lunera. 
O espetáculo Nossa Pequena Mahagonny é fruto, portanto, mais do que de um processo colaborativo, no qual existe um criador que responda pela estruturação dramatúrgica, de um processo que pode ser definido como de criação coletiva, na medida em que todos os criadores não só interferiram diretamente na dramaturgia, mas foram responsáveis por sua criação. Sem dúvida alguma, o percurso de criação do espetáculo acabou por impregnar a estrutura do trabalho, pois, com "mais de oitenta apresentações realizadas em oito anos de existência, esse espetáculo está em constante atualização, sendo passível de absorver em sua dramaturgia as mais diversas transformações". É o que afirma também Davi de Oliveira Pinto, na análise que faz da dramaturgia do espetáculo.

Este traço pode ser exemplificado por uma alteração na linha de uma das personagens, ocorrida recentemente, quando da entrada para o grupo de um novo ator, Camilo Lélis. Este deveria assumir uma das figuras que apresentam o programa, baseada na recorrente Leocádia Begbick (a qual também aparece em outro texto de Brecht, Um homem é um homem). Esta havia sido concebida, inicialmente, pela atriz Bya Braga a partir de, entre outras referências culturais, um modelo de apresentadora católica, cujo objetivo de "evangelizar" os telespectadores evidenciava a instrumentalização do discurso e da postura religiosos, comprometidos ambos, neste caso, com a "máquina de aliciar telespectadores", delineada pelo conjunto do programa televisivo, tal como é mostrado ao longo do espetáculo. Após novo período de ensaios, alguns dos traços religiosos de Leocádia foram deslocados, trazendo o ator, para esta figura, características que aludem a outra vertente religiosa, hoje amplamente instalada em diversos canais de televisão brasileiros: a linha pentecostal, ou, como é mais comumente conhecida, evangélica. Segundo o ator, com a adesão de toda a equipe, a nova versão se mostrou particularmente potente, do ponto de vista cênico e do ponto de vista de uma comunicação mais imediata com a platéia ${ }^{6}$.

\footnotetext{
${ }^{5}$ GRUPO TEATRO INVERTIDO. Por um olhar inverso IN: Cena Invertida: dramaturgias em processo. Belo Horizonte: Edições CPMT, 2010, pg. 10.

${ }^{6}$ PINTO, Davi Oliveira de. Nossa Pequena Mahagonny: aspectos processuais de uma dramaturgia colaborativa IN: Cena Invertida: Dramaturgias em Processo. Belo Horizonte: Edições CPMT, 2010, pp. 26-39.
} 


\subsection{A experiência no projeto Cena 3x4: olhares sobre a cena}

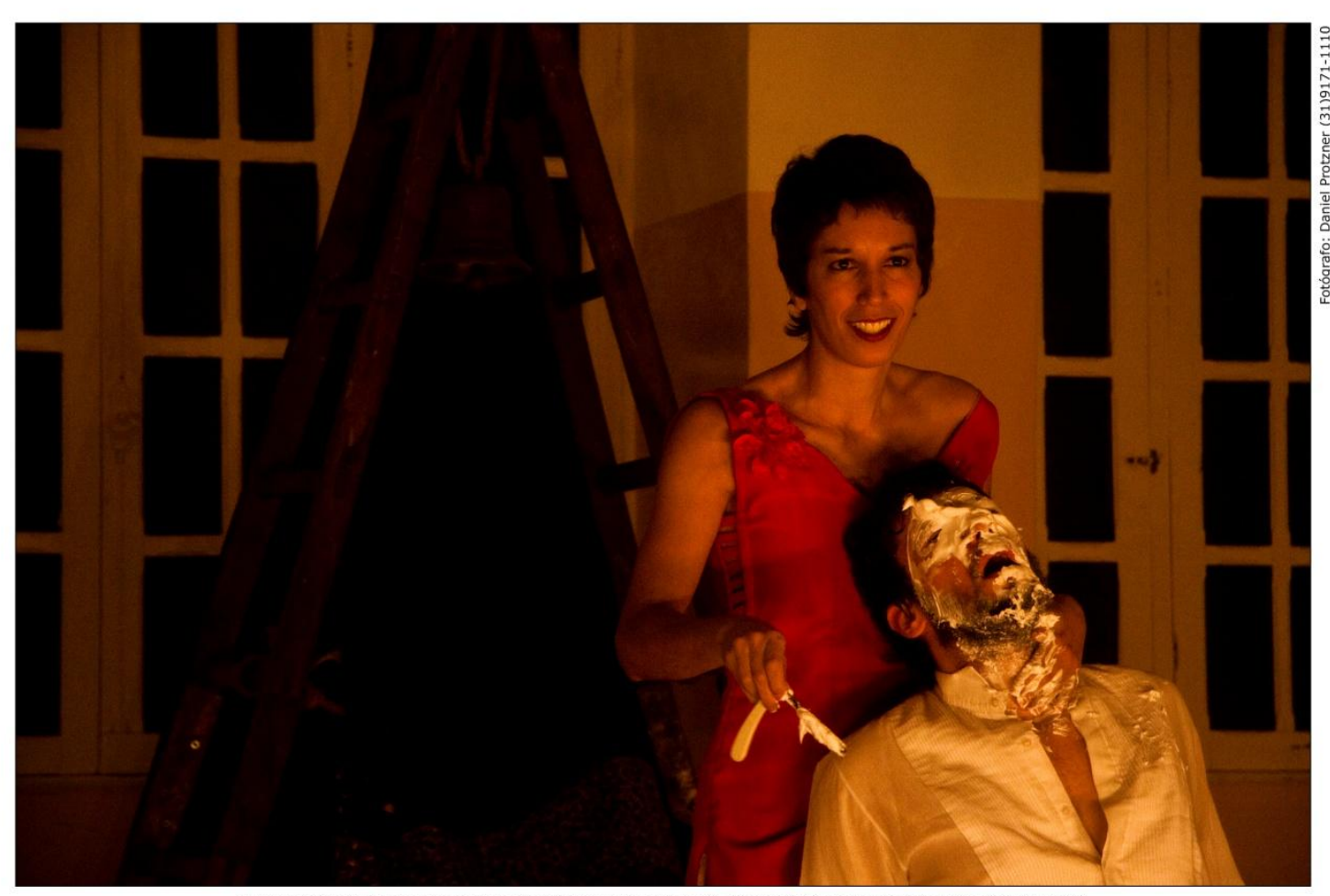

"Lugar cativo" - Grupo Teatro Invertido (Belo Horizonte/MG) / Local: Salão Rosado (São João Del Rey/MG) FIG. 05

Em 2004, o Grupo Teatro Invertido, a partir do convite da Maldita Cia. e do Galpão Cine Horto para integrar a segunda edição do Cena 3×4, decidiu verticalizar a pesquisa de princípios e procedimentos colaborativos na construção de um espetáculo com dramaturgia própria e, juntamente com Cristiano Peixoto, responsável pela direção, e Pollyana Costa Santos, que assumiu a dramaturgia, formaram o núcleo Teatro Invertido, responsável pelo desenvolvimento de uma das montagens daquele ano.

Como não tinham estabelecido nenhum tema ou investigação de linguagem como ponto inicial do percurso de criação, atores, diretor e dramaturga se lançaram no trabalho, tendo como ponto de partida "o vazio da sala de ensaio"?". Tanto os atores do Teatro Invertido como o diretor, também ator, tinham uma formação que privilegiava um treinamento corporal intenso. Os ensaios eram, então, de início, pautados em

\footnotetext{
${ }^{7}$ GRUPO TEATRO INVERTIDO, op. cit., pg. 11.
} 
dinâmicas físicas - propostas, em geral, pelo diretor - que propiciaram o caminho para as primeiras improvisações. Era o caso, por exemplo, do Balance. Esse exercício de ocupação espacial consistia no equilíbrio e preenchimento do espaço pelos atores, a partir do comando do ator que se colocava no centro.

Por outro lado, as discussões que giravam em torno do conceito de colaboração como princípio básico das relações criativas no teatro - pautadas na dissertação de Antônio Araújo e nos artigos de Luís Alberto de Abreu que eram utilizados, pela coordenação do Cena $3 \times 4$, como bases teóricas para o projeto - acabaram por servir como elementos norteadores em relação à temática, "contaminando" as improvisações e proposições dos criadores. Desse modo, o núcleo de criação teve, como primeira escolha temática, questões relacionadas à intolerância e, um pouco mais tarde, ao poder. Esses temas iniciais geraram vários sub-temas, que eram utilizados nas improvisações, tais como "Máquina”, “Dança do Poder”, "Marketing” e “Confinamento”, os quais, por sua vez, acabaram gerando novos desdobramentos: a idéia, por exemplo, de confinamento, era abordada a partir dos espaços: fábrica, igreja, escola, exército.

Tendo a discussão sobre o poder como base principal para as improvisações, o núcleo de criação pesquisava diversas referências para orientar a construção das cenas que serviriam como sustentáculo para o roteiro dramatúrgico. Ou seja, os criadores buscavam pontes que permitissem a eles passar das improvisações soltas para a construção de um material cênico mais definido. Nesse momento, foram várias as referências utilizadas e estas iam de inspirações imagéticas - como o filme $O$ Baile, de Ettore Scola - a textos, tanto teóricos - os quais possibilitavam não só o aprofundamento das discussões temáticas, mas também a discussão sobre as estruturas cênicas e sobre as funções envolvidas no projeto - como literários, que serviam de inspiração para a produção de cenas ou para a criação de jogos, motores para a improvisação. É exemplar o jogo de desinvenção de objetos, proposto pela dramaturga a partir de um poema de Manoel de Barros ${ }^{8}$.

É importante citar que, a partir de maio, a equipe de criação já começara a ser acompanhada por duas relatoras, Ana Hadad e Henaís Deslandes, as quais, a convite

\footnotetext{
${ }^{8}$ Citado em relato: "Desinventar um pente até que ele seja qualquer coisa. Momento de ruptura até que ele se torne outra coisa.

Ou desinventar por meio de usá-lo tanto até que ele seja outra coisa" (Livro das Ignoranças).
} 
do Grupo Teatro Invertido, tinham se agregado ao núcleo com o intuito de possibilitar não só a documentação do processo de criação, mas também a sistematização do trabalho desenvolvido pelo grupo. Muito do percurso de criação do núcleo, exposto aqui, é decorrente de informações colhidas nesses relatos.

Ainda em maio, aconteceu o primeiro Coletivão, encontro no qual todos os envolvidos no projeto tinham a oportunidade de compartilhar experiências. No Coletivão, foram realizadas dinâmicas distintas para os encontros: no primeiro dia, cada núcleo de criação, em separado, apresentou seu processo de trabalho e materiais cênicos para os orientadores e coordenadores do Cena $3 \times 4$, que levantaram questões relacionadas tanto à qualidade das cenas apresentadas como ao trabalho de cada função artística específica e aos procedimentos de colaboração. No dia seguinte, todos os núcleos de criação se encontraram, para discutir seus temas e perspectivas sobre o trabalho e para demonstrações de exercícios ou estratégias que possibilitavam à dramaturgia nascer do diálogo entre as funções. Nesse encontro, foi possível também, aos núcleos de criação, levantar suas dúvidas em relação ao processo e discuti-las com os coordenadores locais que eram, naquele ano, além dos integrantes da Maldita Cia. e Chico Pelúcio (diretor geral do Galpão Cine Horto), o coordenador pedagógico do Galpão Cine Horto, o professor Fernando Mencarelli. Ao final do encontro, ficou determinada, como tarefa a ser realizada para o próximo Coletivão (que teria lugar em agosto), a construção e apresentação de uma primeira estrutura dramatúrgica.

No encontro do núcleo Teatro Invertido com os orientadores externos, várias questões foram colocadas por Abreu e Antônio Araújo para o desenvolvimento da criação. Uma das questões mais importantes referia-se ao fato de que o trabalho desenvolvido pelo núcleo estava, ainda, em um nível muito descritivo: segundo eles, era possível entender do que se falava, mas faltava, para o espectador, a vivência do que estava sendo mostrado. Nesse sentido, faltava o processo humano, a experiência. Além disso, foi colocado também que o processo de trabalho parecia estar mais voltado para a estruturação dos materiais criados do que, propriamente, para o desenvolvimento da criação. Ou seja, para os orientadores, o núcleo de criação tinha “invertido" o processo, buscando a formalização da cena antes de seu desenvolvimento.

Em relação ao trabalho específico da dramaturgia, foi salientado que, no momento inicial do processo (pois, em cada etapa de desenvolvimento do processo de 
criação, haveria modificações em relação à forma de trabalho), o dramaturgo seria ele também, um improvisador - assim como os atores - e que as improvisações dramatúrgicas deveriam partir do olhar do dramaturgo sobre o tema, de suas angústias e questões. Em outras palavras, mais do que se preocupar em criar cenas estruturadas, deveria o dramaturgo, naquele momento, agir como um provocador de novos materiais cênicos.

A partir do coletivão, a meta de cada núcleo - além do desenvolvimento do material cênico a partir dos apontamentos feitos pelos coordenadores e orientadores do Cena $3 x_{4}$ - passou a ser verticalizar a investigação em torno dos princípios de uma criação colaborativa, como salienta Ana Hadad ${ }^{9}$, relatora do núcleo Teatro Invertido: “fazer com que realmente o processo colaborativo aconteça. Que em prol do espetáculo, não se ceda a qualquer [forma de] processo. Que seja um processo no qual todos os integrantes do grupo se enxerguem, se vejam dentro do material que está surgindo”. Para o núcleo Teatro Invertido, no qual a escolha temática estava entrelaçada com a investigação sobre o processo, tornou-se crucial buscar uma definição temática. Era necessário, também, radicalizar as propostas da dramaturgia e partir para a busca de vivências que propiciassem transformar as formas e conceitos em experiências humanas. Em 15 de junho, Ana Hadad registrou:

Estamos no momento de buscar a vivência das coisas. Uma experiência da onde (sic) surgirá o tema do espetáculo. É sugerido que trabalhemos por temas semanais, temas que percorrerão todo o trabalho. Precisamos nos aproximar dessa vivência desde o momento em que entramos na sala de ensaio. Temos pouco tempo de trabalho e isso vem contra nós ${ }^{10}$.

Como ponto de partida para a busca dessas vivências, foi proposta, então, a construção de cenas individuais sobre o tema "ritual", por parte dos sete integrantes do núcleo Teatro Invertido, uma vez que todos, embora assumindo funções distintas, eram atores. A partir das cenas apresentadas, inclusive pelas relatoras, foram

\footnotetext{
${ }^{9}$ Registro do Processo de Criação de Lugar Cativo. Cedido pelo Grupo Teatro Invertido para esta pesquisa de doutoramento.

${ }^{10}$ Idem.
} 
estabelecidas improvisações que tinham como cerne a noção de espaço de cena pensado como um espaço ritual - e de fora de cena. No jogo que foi estabelecido, os atores que ficassem dentro do espaço de cena - demarcado por bastões - deveriam se relacionar com o ator que estivesse no espaço de fora, como este sendo um espectador. Três eram os pontos nodais: o estado psicofísico (ator), a relação (o outro ator) e o olhar (espectador). Com o desenvolvimento desses jogos improvisacionais, apareceram algumas recorrências temáticas e, a partir de proposições da dramaturga, concernentes às relações entre (1) o público e o privado e (2) o que é visível e o que é invisível, o tema do olhar começou a se impor. No entanto, talvez por falta de propostas mais concretas da dramaturgia, ou seja, de proposições de cena, os materiais levantados pelos atores, em suas improvisações, acabaram não sendo aprofundados e, com isso, o tema do olhar foi momentaneamente "engavetado".

No início de julho, o diretor, Cristiano Peixoto, propôs que todos os envolvidos no processo criassem cenas individuais sobre o tema "deserto", que espelhava bem o momento pelo qual o núcleo de criação estava passando. As cenas foram apresentadas: o núcleo de criação buscava, desesperadamente, os pontos em comum. A partir da improvisação de Ana Hadad, em que ela construía um gabinete para se colocar em exposição, novamente voltou à tona a questão do público e do privado, proposta anteriormente pela dramaturga, Pollyana Costa Santos. Na improvisação feita pela relatora, começava a se apresentar, também, a discussão da dependência do artista em relação ao espectador.

Pollyana Costa Santos, motivada por essa questão, sugeriu aos atores que eles criassem gabinetes individuais, nos quais pudessem improvisar relações com o público e o grupo começou a cobrar dela um maior envolvimento na criação, por meio da apresentação de textos dos quais eles pudessem partir. Diante da cobrança, a dramaturga alegou que, sem um tema definido, ela não tinha segurança para apresentar cenas escritas. Estava instalada a crise, pois, a menos de um mês do próximo Coletivão, no qual deveria ser apresentada uma estrutura dramatúrgica, o núcleo de criação não havia definido ainda um tema que pudesse orientar a construção dessa estrutura. Os criadores resolveram fechar um acordo: seria dada mais uma semana de prazo para, a partir do levantamento do material improvisado 
anteriormente, se mapear os pontos comuns, de interesse de todos, e definir um eixo temático que pudesse nortear a escolha do material cênico.

A partir desse mapeamento, a relação entre o público e o privado tornou-se um "bem comum", sendo definida como eixo temático. O núcleo de criação se concentrava, especialmente, na noção de espetáculo. Tendo a espetacularização do privado como cerne, Cristiano Peixoto propôs uma imagem: "circo de horrores humanos", na qual, no lugar de acrobacias ou malabarismos, um cardápio de horrores íntimos, pessoais, deveria ser oferecido ao espectador. A imagem revelou-se profícua e os criadores partiram novamente para a pesquisa de fontes que pudessem auxiliar as improvisações e nas quais pudessem explorar, principalmente, as relações entre o grotesco e o belo.

A partir do texto $O$ Corpo Perigoso - no qual a dança é vista como um instrumento para se enfrentar a moral e é discutido o poder do olhar - a atriz Rita Maia retomou a idéia da Dançarina, improvisada por ela no primeiro Coletivão, e começou a desenvolvê-la, tendo como mote a noção de exaustão: agora, a personagem deveria dançar até seu limite máximo, deveria dançar até cair. Algumas relações levantadas a partir do tema do poder também foram retomadas e surgiu a cena da transformação, na qual uma mulher, infeliz por não atender ao padrão de beleza vigente na sociedade contemporânea, submete-se ao jogo perverso do criador, aceitando ser "transformada" por meio de martírios físicos, dos quais o espectador é voyer. A partir dessa cena, desenhada por Pollyana Costa Santos, foi fortalecida a idéia de se trabalhar a relação de interdependência entre artista, obra e espectador como fio condutor para a construção dramatúrgica.

PHAOS Ela não preenche os requisitos do mundo. Observem! É pele e osso e cabelos escassos. Os olhos parecem saltar de tanto susto e vergonha de existir. Olhem... Treme de fraqueza e falta de costume. Não está acostumada com tantos olhares... Sabemos que os olhares não são tantos, mas a coitada não está acostumada nem mesmo com os próprios olhos sobre si mesma. Olhe pra você, criatura! (...)

Lumen esquiva-se de olhar.

PHAOS para Lumen, em tom sussurrado Não se olha, por medo de ver que é um equívoco da criação. Para a platéia. Mas ela chegou até aqui, 
neste lugar, porque ainda quer acreditar que pode ser transformada. Sim, senhoras e senhores, (...) essa pobre criatura vai conseguir o seu punhado de felicidade, assim que for transformada. Sim! Senhoras e senhores, ela será transformada! Está preparada?"

Pressionados pelo tempo e preocupados com a apresentação que deveria ser realizada no próximo Coletivão, de uma estrutura dramatúrgica aos orientadores e coordenadores do projeto, a equipe de criação apegou-se à cena proposta pela dramaturgia e, utilizando-a como base, começou a estruturar um roteiro de ações, ao qual se agregou a cena da dançarina, como mais um número perverso a ser apresentado à platéia. Nessa estruturação, havia também a preocupação de se definir o espaço cênico e a relação com o espectador.

Pollyana Costa Santos, considerando que deveriam, a partir da cena, buscar sua vivência - a "experiência humana" de que falara Abreu - a fim de aprofundá-la e permitir o surgimento de novos materiais, questionou essa definição. Para ela, antes de partir para uma estruturação, a seu ver, prematura e formalizada, a equipe de criação deveria experimentar as possibilidades da cena. No entanto, a preocupação dos outros criadores envolvidos no processo era, naquele momento, finalizar uma estrutura cênico-dramatúrgica que pudesse ser apresentada no dia 15 de agosto e a dramaturga acabou por ceder à pressão geral.

No desenvolvimento do processo de criação pelo núcleo Teatro Invertido parecia haver, apesar da aparente divisão do trabalho por meio das funções artísticas definidas pelo projeto, uma mistura de responsabilidades, principalmente no campo da dramaturgia, em que as opiniões e percepções de todos, inclusive das relatoras, tinham tanto peso como as propostas feitas pela dramaturga.

Em 15 de agosto, o núcleo de criação apresentou, para quase toda a equipe de coordenação e orientação do Cena $3 \times 4$ (Antônio Araújo não pode comparecer), a estrutura cênico-dramatúrgica que havia sido levantada, na qual já havia apontamentos de iluminação e cenografia, tais como a utilização de biombos e cortinas e a manipulação da luz por um dos atores, além da proposta de divisão da platéia em masculina e feminina. Tanto na apresentação ocorrida durante o Coletivão como na

\footnotetext{
${ }^{11}$ SANTOS, Pollyana Costa. Lugar Cativo IN: Cena Invertida: dramaturgias em processo. Belo Horizonte: Edições CPMT, 2010, pp. 82-83.
} 
posterior, feita para Tiche Vianna, durante a oficina que ela ministrou, em setembro, para os atores envolvidos no projeto, a questão apontada pela dramaturga apareceu. Para Tiche Vianna ${ }^{12}$, por exemplo, havia um risco concreto do núcleo Teatro Invertido não conseguir, de fato, gerar, a partir do vasto material criativo apresentado, uma dramaturgia que refletisse os desejos e expectativas da equipe de criação em relação ao espetáculo, porque, segundo ela, "as coisas estavam fora dos criadores”, elas estavam "mais explicadas do que realizadas, concretamente, em cena". De certo modo, as questões apresentadas por Tiche Vianna refletiam uma percepção que Abreu e Antônio Araújo tinham tido, já no primeiro Coletivão, do trabalho desenvolvido por esse núcleo.

Buscando dar conta das questões apontadas pelos “espectadores” especializados, a equipe de criadores resolveu aprofundar o estudo dos personagens, direcionando todo o treinamento atoral para o desenvolvimento de suas ações e intenções. Contudo, o processo de criação desse núcleo tinha chegado a um sério impasse, para o qual parecia não haver solução, pois era gerado, precisamente, pelo modo com que o Grupo Teatro Invertido percebia não só a própria criação, mas também a metodologia colaborativa. Reféns do resultado, o grupo não conseguira abrir mão dele e havia caído na armadilha da formalização. Evidentemente, o impasse em que o núcleo estava mergulhado não era somente conseqüência da visão do grupo, mas do modo como as relações tinham se desenvolvido durante o processo de criação, porque, nessa busca pelo resultado - pelo porto seguro que, no entendimento do grupo de atores, garantiria a qualidade da criação cênica - eles acabavam por pressionar o restante da equipe. $O$ diretor e a dramaturga, talvez em razão da própria inexperiência e conseqüente pouco domínio de ferramentas da função artística que exerciam dentro do processo, mesmo discordando de inúmeros aspectos exigidos pelo grupo, abriam mão das próprias visões e concordavam com as soluções apontadas pelos atores, definindo elementos de encenação e de dramaturgia a partir da perspectiva da atuação. Era como se o parâmetro para definição dos elementos que comporiam o espetáculo, mais do que a especificidade de cada função, fosse o consenso, ou a voz da maioria.

\footnotetext{
${ }^{12}$ Observações tiradas do registro produzido por Ana Hadad.
} 
A dois meses da mostra pública das montagens, geradas pelos processos desenvolvidos pelos núcleos de criação participantes do Cena 3×4, os integrantes do núcleo Teatro Invertido, sem saída para o impasse em que estavam mergulhados e já desgastados pelo processo que tinham experimentado, se voltaram para a definição dos aspectos técnicos que ainda estavam obscuros, tais como o desenho da luz e a cenografia, sem alterar muito a estrutura dramatúrgica apresentada anteriormente. Somente após a estréia do espetáculo Lugar Cativo, em novembro de 2004, eles resolveram reestruturar a dramaturgia e voltaram para a sala de ensaio, para mais quatro meses de processo, nos quais buscaram incorporar à composição do espetáculo - e do texto dramatúrgico - percepções advindas do primeiro contato do espectador com a obra.

A partir da experiência de participação dentro do projeto Cena $3 \times 4$, a busca de uma relação mais direta do espectador com a gênese da obra e uma percepção de que esta relação poderia alterar, substancialmente, o desenho da cena e da dramaturgia, ou seja, a percepção do espectador como co-autor do espetáculo, passou a fazer parte do percurso desenvolvido pelo grupo.

Essa prática, exercitada de maneira intuitiva na criação de "Lugar Cativo", passou a permear os processos criativos seguintes. Talvez pela natureza autoral de nossos trabalhos, uma postura ativa e participativa do espectador tem sido elemento fundamental na construção dramatúrgica dos espetáculos. Desde então, temos buscado criar oportunidades durante nossos processos para que os espectadores possam exercer essa participação, seja através de mostras de trabalho, ensaios abertos ou temporadas-laboratório ${ }^{13}$.

Além disso, o processo de criação de Lugar Cativo sedimentou uma alteração significativa em relação ao pensamento dos integrantes do grupo sobre seu modo de produção e pesquisa, antes voltado especificamente para o treinamento de atores. Segundo eles (GRUPO TEATRO INVERTIDO, 2010: 11), a participação no projeto “agregou à nossa trajetória uma importante contribuição ideológica e sedimentou a

\footnotetext{
${ }^{13}$ GRUPO TEATRO INVERTIDO, op. cit., pg. 12.
} 
colaboração como princípio ético fundamental no trabalho do grupo até os dias de hoje".

\subsection{Em busca de uma dramaturgia pós-dramática}

Em busca de uma efetiva participação do público no trabalho de criação e disposto a dar continuidade à investigação em torno dos princípios de uma criação colaborativa, iniciada, de fato, no projeto Cena $3 \times 4^{14}$, o Teatro Invertido formatou, no final de 2005, o projeto Medeias de Rua (vencedor do Prêmio Myriam Muniz de Teatro de 2006), junção do desejo do grupo de trabalhar com uma temática que envolvesse a situação de abandono e marginalidade em que vivem os moradores de rua com a proposta do diretor convidado, Amaury Borges, de utilizarem, como referência para a construção de uma dramaturgia própria, o mito grego de Medéia, mulher abandonada pelo marido e exilada da cidade em que vivia, ou seja, também em situação de marginalidade e abandono. As principais fontes para o trabalho eram tanto os textos Medéia, de Eurípides e Medéia, de Sêneca, como MedeaMaterial, de Heiner Müller.

Faziam parte da equipe definida pelo projeto, além dos atores do Grupo Teatro Invertido - Rita Maia, Leonardo Lessa e Rogério Araújo - e do diretor Amaury Borges, outros integrantes da Maldita Cia. - a dramaturga Letícia Andrade, a cenógrafa Ines Linke e o sonoplasta Admar Fernandes - e os atores convidados Camilo Lélis, Janaína Rodrigues e Rafael Vilar ${ }^{15}$. Ao longo do processo de criação, alguns atores foram se desvinculando do trabalho e também da cena. Na atuação, permaneceram Rita Maia, Leonardo Lessa e Camilo Lélis. Rogério Araújo assumiu a iluminação, juntamente com o diretor.

\footnotetext{
${ }^{14}$ Como já foi discutido no presente capítulo, a experiência de criação do espetáculo Nossa Pequena Mahagonny não pode ser considerada uma experiência de criação colaborativa, na medida em que não havia o exercício da dramaturgia, um dos eixos fundamentais dessa metodologia de criação.

${ }^{15}$ A maior parte das informações sobre o processo de criação de Medeiazonamorta foi cedida pela atriz Rita Maia, por meio de entrevistas, do seu caderno de ensaio e também pela dissertação: MAIA, Rita de Cássia Pinho. $\mathrm{O}$ ator em questão: um foco na função do ator no Processo Colaborativo do Grupo Teatro Invertido. Dissertação de Mestrado. Belo Horizonte: UFMG, 2010.
} 
Amaury Borges, como integrante da Maldita, companhia teatral que investigava, na poética de seus espetáculos, a construção de uma dramaturgia do espaço, propôs ao grupo que um dos eixos da pesquisa a ser realizada para a construção do espetáculo fosse, justamente, a incorporação, em sua estrutura cênico-dramatúrgica, de elementos relacionados ao lugar proposto como espaço de encenação.

Segundo Luiz Carlos Garrocho, na análise ${ }^{16}$ que tece da dramaturgia processual de Medeiazonamorta, espetáculo resultante do desenvolvimento do projeto Medeias de Rua, o que caracterizaria uma dramaturgia do espaço é, mais do que a utilização de um lugar alternativo para as montagens, como praças ou galpões, o fato desse espaço interferir no texto da encenação.

Os espetáculos que ocorrem em lugares como galpões ou salas costumam ser revestidos, ou seja, caracterizados cenicamente para a montagem. Mesmo que utilizem o máximo do "espaço vazio", tais criações tendem a abstrair dessa materialidade, a fim de configurar um universo ficcional. Diferente disso, no espaço encontrado não há essa "cobertura" sobre a arquitetura existente. Ocorre, antes, um jogo envolvendo tanto a semântica (usos correntes ou abandonados, mas que deixam traços) quanto à sintaxe (linhas, planos, volumes etc.) do lugar. $\mathrm{E}$ de tal modo que essa materialidade passa a fazer parte dos diversos planos e linhas desse fluxo operacional e expressivo que constitui a encenação (desde seu caráter de instalação às ações operadas por luzes, sons, objetos e atores), gerando confluências, atritos, divergências e misturas entre ficção e real ${ }^{17}$.

No processo de criação de Medeiazonamorta, o espaço encontrado - termo adotado por Garrocho a partir da utilização que dele faz a encenadora Ariane Mnouchkine ${ }^{18}$ ao definir o espaço utilizado, fora dos edifícios teatrais, para a criação da

\footnotetext{
${ }^{16}$ GARROCHO, Luiz Carlos. Medeiazonamorta: dos corpos, dos planos e do todo aberto IN: Cena Invertida: dramaturgias em processo. Belo Horizonte: Edições CPMT, 2010, pp. 56-73.

${ }^{17}$ Idem: 59.

${ }^{18}$ Em entrevista concedida a Gaelle Breton, publicada em Theatres (BRETON, 1989), Mnouchkine faz uma analogia a partir da expressão "objet trouvé" (tradução francesa de ready-made), na qual ela transporta o conceito de ready-made (Duchamp) para a questão do espaço, ou seja, do mesmo modo que nas artes plásticas utilizam-se objetos "comprados prontos" na composição de obras, a encenação jogaria com os elementos materiais - arquiteturais - e imateriais - dos usos cotidianos e da memória do lugar do espaço "encontrado pronto".
} 
cena contemporânea - foi um laboratório desativado de engenharia sanitária localizado em uma famosa zona de baixo meretrício da cidade, a Rua Guaicurus, conhecida também por ser um ambiente de violência e marginalidade, pois, localizada no hipercentro de Belo Horizonte, é freqüentada, ainda, por moradores de rua e viciados em drogas.

Em maio de 2006, o processo foi efetivamente iniciado e a equipe de criação se lançou no "universo de amor e abandono do mito, relacionando-o com a marginalidade e a exclusão no ambiente urbano" (GRUPO TEATRO INVERTIDO, 2010: 12). No entanto, apesar do desejo de se trabalhar com uma dramaturgia do espaço, o lugar ainda não havia sido encontrado.

Borges perseguia a idéia de trabalhar com uma grande instalação em cena. Miller (sic) se refere em seu texto: "a paisagem dura mais que o indivíduo". Portanto, desde os primeiros encontros, o grupo tinha noção de que o espaço de apresentação do espetáculo tinha que ser diferenciado. Foram muitos os ensaios no pátio externo do Centro Cultural da UFMG, local onde o grupo trabalhava.

Algumas incursões na rua também foram realizadas, apesar do grupo saber que não era exatamente um trabalho de rua que iria ser feito. Algumas sugestões de lugares diferenciados já estavam no pensamento do grupo. Lugares tais como motel, uma rua sem saída, lixão, puteiro. A idéia era trabalhar com a noção de um lugar de passagem, uma zona neutra, o lugar do estrangeiro, daquele que não pertence, assim como Medéia não pertencia à cidade de Corinto ${ }^{19}$.

Durante o processo de criação, as experiências de imersão nesses espaços "estrangeiros" foram fundamentais para agregar, não apenas à dramaturgia, como também à composição dos atores, em sua maioria oriundos da classe média, elementos relacionados à exclusão na qual vivia Medéia.

Como ponto de partida, no entanto, a equipe de criação realizou a leitura e o estudo dos textos de referência. As imagens contidas no texto de Müller estavam mais próximas da visão dos atores (e também do diretor) e, tendo MedeaMaterial como fonte de inspiração, eles partiram para as improvisações, buscando criar, já nesses

\footnotetext{
${ }^{19}$ MAIA, 2010: 74 .
} 
primeiros materiais cênicos, uma defesa do ponto de vista dos personagens: Medéia pura decisão, Jasão primeiro colonizador, Medéia puta, as crianças ${ }^{20}$.

Ainda em maio, eles receberam a visita da pesquisadora Tereza Virgínia, professora da Faculdade de Letras da UFMG e especialista em tragédia grega. Nesse encontro, foram discutidos não somente o mito grego e a visão de Eurípides sobre o sofrimento humano, mas também as noções de tragédia, piedade, horror e dilaceramento, por meio das quais Virgínia buscava tecer analogias com a contemporaneidade: "todo morador de rua tem em seu imaginário a possibilidade de um Deus Ex-Machina: achar um bilhete premiado, casar com uma pessoa rica, ser descoberto por um olheiro ${ }^{21 "}$.

Com o estudo sobre o mito grego, a dramaturga, Letícia Andrade, sentiu necessidade de aproximá-lo do ponto de vista dos artistas envolvidos no processo e sugeriu, aos atores, que improvisassem, a partir do texto de Eurípides, materiais cênicos que traduzissem sua visão do mito e seus interesses pessoais. Os atores apresentaram seus depoimentos e começou a se configurar as primeiras abordagens do mito de Medéia $^{22}$ : Janaína Rodrigues (puta, travesti), Rogério Araújo (criança abandonada), Camilo Lélis (mãe-natureza, que gera e mata), Leonardo Lessa (o político, o conquistador), Rita Maia (a mulher traída). Muitos dos materiais cênicos e dramatúrgicos desenvolvidos posteriormente tiveram sua origem nos depoimentos pessoais dos atores, que encontravam, nesse trabalho, uma grande liberdade de expressão e uma enorme disponibilidade física e emocional.

Em junho, já ensaiando no Centro Cultural da UFMG - lugar vizinho do laboratório de engenharia sanitária que, mais tarde, viria a ser o espaço de encenação do espetáculo - surgiu a necessidade de se trabalhar em outros locais que não fossem a sala de ensaio, em lugares que a equipe de criação denominava como "espaços diferenciados". Os criadores partiram, então, para as pesquisas-laboratórios nos inúmeros hotéis de prostituição existentes na Rua Guaicurus. Contaminados pelas imagens de Müller, eles buscavam, também, a criação de uma paisagem, por meio da vivência e improvisação de determinados "estados" nos espaços externos do Centro

\footnotetext{
${ }^{20}$ Conforme o caderno de ensaio de Rita Maia.

${ }^{21}$ Idem.

${ }^{22}$ Idem.
} 
Cultural da UFMG. Segundo Lehmann², para quem o teatro pós-dramático "é um teatro de estados e de composições cênicas dinâmicas", o "estado é uma figuração estética do teatro que mostra mais uma composição do que uma história, embora haja atores vivos representando" (LEHMANN, 2007: 114).

No ensaio do dia 12 de junho, no qual os atores deviam apresentar cenas improvisadas a partir de um trecho do texto de Sêneca, selecionado pela dramaturga, Letícia Andrade, a atriz Rita Maia apresentou seu depoimento pessoal que, posteriormente, se tornaria a cena inicial do espetáculo e um forte elemento da dramaturgia, por meio da duplicação de sua imagem no texto - noiva-margarina, noiva-esgotada - e nas ações desenvolvidas por Rita Maia e por outro ator, Camilo Lélis.

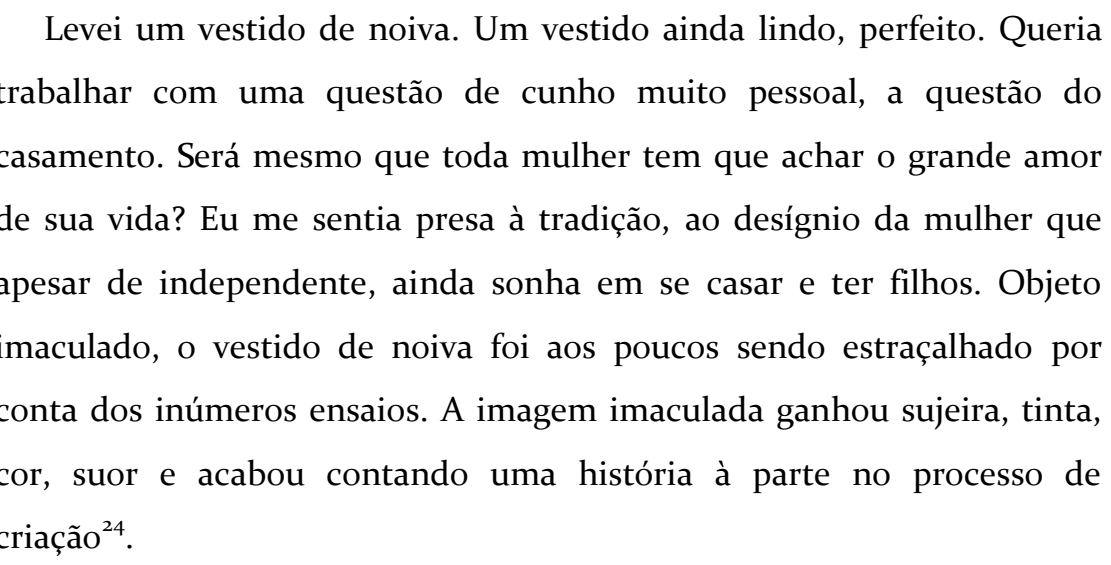

A partir de depoimentos pessoais - não só de Rita Maia, mas também dos outros atores: Leonardo Lessa e Camilo Lélis - e da exploração de espaços ficcionais (grande hotel, banquete, câmara nupcial) e de lugares reais, como motel, quarto de puteiro, boteco, lixão, começou a ser configurado o texto dramatúrgico e começaram a ser aprofundadas as idéias que norteavam a criação e o desenvolvimento do material cênico: nascimento, matança, traição, casamento. Mais do que buscar uma releitura do mito de Medéia (ou de suas versões textuais), a dramaturgia buscava, a partir dos elementos simbólicos de que tratava o mito, trabalhar com questões candentes das relações humanas, presentes tanto na história de Medéia como na contemporaneidade.

\footnotetext{
${ }^{23}$ LEHMANN, Hans-Thies. Teatro pós-dramático. São Paulo: Cosac \& Naify, 2007.

${ }^{24}$ Conforme o caderno de ensaio de Rita Maia.
} 
Questões concernentes ao papel da mulher, às relações entre mãe e filho e à predominância do masculino.

\begin{abstract}
GENERAL começa a subir Homem não chora. Lá no alto o topo do mundo, o lugar mais alto do pódio, palanque, púlpito, planalto. Da parte mais alta da escada. De cima ele pode ver em quantas cabeças deseja pisar, contemplar o território da sua conquista, traçar estratégias e planos. O barulho da água. Pranto das mulheres que deixei para trás, fortalezas que destruí. Na minha testa, pesa o letreiro "Eu sou um covarde". Entra na plataforma. Em voz de comando. Alça o primeiro lugar. O palanque. (...) Sabe que lá suas palavras são lei ${ }^{25}$.
\end{abstract}

Com o aprofundamento dessas questões, foram configurados também os actantes que iriam, como a(s) noiva(s), transitar em cena: o general, a mãe-aborto, o filho-cão, a putinha de zona, a hospedeira. Sem possuir uma história, um caráter social e/ou psicológico, nem encontrar um desenvolvimento no desenrolar das cenas, esses actantes não iriam ser configurados exatamente como personagens e o texto não viria a servir como expressão de suas vontades nem como arcabouço de suas ações. A eles, seria possível, antes de chamá-los de personagens, designar, a partir de Jean Pierre Ryngaert $^{26}$, como figuras, na medida em que o caráter individualizado e subjetivo é substituído pelos efeitos da máscara, da persona, ou seja, por um modo de atuação atravessado por "estados de palavra", por dispositivos de elocução que se constituem como papéis provisórios. Para Ryngaert, as figuras, sem interioridade ou substância psicológica, vão existir como imagens dadas a ver, ou melhor, como pura exterioridade, como presença puramente fenomenológica no aqui e agora da enunciação teatral, aspecto evidenciado por Luiz Carlos Garrocho em sua análise de Medeiazonamorta:

Temos três figuras que se transmutam ou entram em devir: noivamãe-mulher, filho-cão, homem-general etc. (...) Surgem, diante de nós, actantes que se caracterizam pelos estados pulsionais e pela presença lírica e épica do texto falado em quase todo o espetáculo. (...) Em

\footnotetext{
${ }^{25}$ ANDRADE, Letícia. Medeiazonamorta IN: Cena Invertida: dramaturgias em processo. Belo Horizonte: Edições CPMT, 2010, pg. 129.

${ }_{26}$ RYNGAERT, Jean-Pierre. Le personnage théâtral contemporain : décomposition, recomposition. Paris : Éditions Théâtrales, 2006, pp. 117-118.
} 
Medeiazonamorta há um bombardeio de ações e falas, estados e relações, mas nunca a posição de um ser individual configurando seu destino (ou sendo configurado por ele). São paisagens, destroços humanos, incongruências e tecidos rotos. A descrição social, portanto épica, é também lírica e pulsional. Esta última resolve-se, no espetáculo, pela exposição dos corpos e por jogos de simulação, que vão da masturbação à cópula, incluindo o ato de carregar corpos mortos ${ }^{27}$.

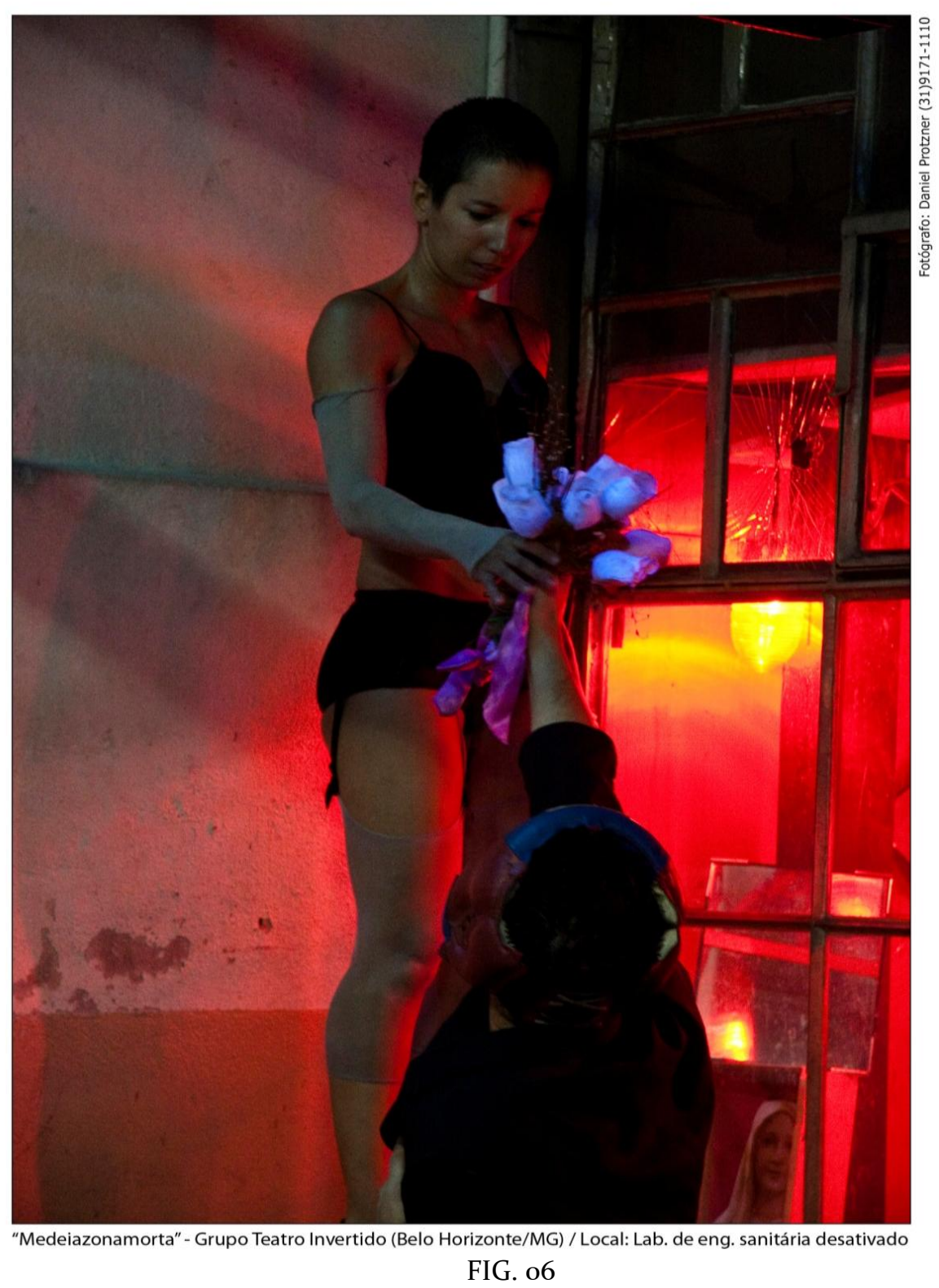

${ }^{27}$ GARROCHO, op. cit., pp. 67-68. 
Em Medeiazonamorta, a dramaturgia cumpre, de certo modo, um exercício de fabulação, pois é perceptível, durante o desenrolar do espetáculo, o desenvolvimento de uma determinada linha narrativa que vai da entrada/casamento da noiva ao parto expresso na dicotomia nascimento/aborto do filho-cão - à traição e à morte. Contudo, ela ganha autonomia da cena e o texto, como expressão poética da dramaturga, não se preocupa em recobrir as ações ou o desenvolvimento da linha narrativa, e acaba por funcionar como um intenso jorro verborrágico, como uma textura pós-dramática (LEHMANN, 2007: 139) na qual são produzidas "estruturas antes parciais do que totais". Nessa dramaturgia, "realiza-se o sacrifício da síntese para alcançar a densidade de momentos intensos", pois, se é desenvolvido algo semelhante ao conjunto, este não é organizado "segundo modelos previamente dados de coerência dramática".

No que concerne à relação entre dramaturgia e espaço encontrado, é necessário dizer que, apesar de grande parte do texto dramatúrgico já estar estruturado quando foi definido o local de apresentação da obra, ele foi, em contato com o laboratório desativado de engenharia sanitária, redesenhado (MAIA, 2010: 77). O espaço encontrado - não por acaso vizinho do Centro Cultural da UFMG, no qual a equipe de criação ensaiava - concretizava, no plano da encenação, o lugar de abandono e marginalidade perseguido pelo grupo desde a concepção do projeto inicial e a dramaturgia - bem como a encenação - foi ampliada e alterada, incorporando novos elementos, surgidos do diálogo dos corpos e textos com o laboratório de tratamento de esgoto que "materializava a morada de Medéia, mulher dejeto da sociedade" (GRUPO TEATRO INVERTIDO, 2010: 13).

HOSPEDEIRA desce Agora eu sou a sua hospedeira. É o orgulho que sustenta essa mulher. Me salva da queda. A hospedeira afunda no seu esgoto, farejando as bactérias e excrementos da indústriahumana, que ainda sobrevivem no lugarreservatório guardado, procura sua memóriamausoléu. Olha o lugar, procura por vida O tempo de agora é o do presente, e os organismos que estão aqui expostos, estão mortos. Meu corpo é o traço de vida, a cartilagemcartografia do lugar. Atravessa o corredor atrás do público. Realiza ações de ligar máquinas, organizar tubos de ensaio, arrumar objetos no espaço. Espaço de sistema de tratamento de esgoto por processos anaeróbios. Meu esôfagocano 
alimenta os tubos de energiaraiva com circulação de chorochorume. No alto, a caixa d'água, reservatório de porra. Porosorifíciosedifícios, vidrosvenenos. Quem fez o homem? Quem? Leva a geladeira até o centro. Devo falar da criançabactériaresistente. Para se realizar o experimento nascimento, é necessário tempo de maturação do espécime. O tempo dentro da barrigatubodeensaio. Os enjôos, vômito, ciclos menstruais, azia, excrementos... Parto, abro meu útero rasgado, casulo lambuzado dos filhos que gerei. Bactérias fágicas, emocionalmente instáveis. (...) Eu e minha viagem marítima, rastro de sangue. Os pedaços do irmão sendo atirados ao mar... A imagem do pai, recolhendo o corpo do filho esquartejado, meu irmão. E o mar... (...) Mergulha no tanque, sai da água. A hospedeira infiltra no esgoto do macho e torna a alma mais potável ${ }^{28}$.

Em novembro de 2006, o espetáculo Medeiazonamorta estreou, em uma temporada-laboratório, termo cunhado pelos criadores para designar os encontros com o público que permitiam a inserção do espectador na criação, pois, dos debates realizados após cada sessão, surgiam diversas propostas de alteração não só do texto dramatúrgico, mas de elementos da encenação e do roteiro de ações dos atores. Essas alterações eram experimentadas diretamente na cena a cada nova apresentação, passando a fazer parte da dramaturgia da obra.

\subsection{Por uma dramaturgia autoral}

Com a entrada do ator Camilo Lélis - ainda durante o processo de criação de Medeiazonamorta - e da atriz Kelly Crifer, o grupo, sentindo necessidade de entender a criação e composição da cena do ponto de vista da direção e da dramaturgia, convidou a diretora Cida Falabella e a mim, na qualidade de dramaturga, para assumirmos a orientação desses dois campos de criação dentro do projeto Ator Invertido, cinco sentidos para a construção da cena (aprovado pelo Prêmio Myriam Muniz de Teatro de 2008).

\footnotetext{
${ }^{28}$ ANDRADE, op. cit., pp. 117-118.
} 


\begin{abstract}
Tal necessidade se sustentava na conclusão de que na criação colaborativa é fundamental, para que o ator conquiste a condição de ator-criador autônomo, que ele dialogue com as outras funções que compõem a criação da cena, principalmente a direção e a dramaturgia. Os requisitos para essa conquista nos despertou o interesse em experimentar procedimentos de criação específicos dessas outras áreas para, assim, conhecê-las em maior profundidade ${ }^{29}$.
\end{abstract}

O projeto tinha como foco o desenvolvimento de cinco experimentos de criação colaborativa, nos quais os atores do grupo se revezariam nas funções de atuação, direção e dramaturgia. Cada experimento teria como eixo temático um dos cinco sentidos perceptivos humanos: olfato, paladar, visão, audição e tato. Apesar da composição da equipe de criação de cada experimento bem como o sentido que iria nortear a criação já terem sido sorteados, optamos por começar o trabalho de pesquisa a partir de uma investigação mais livre, na qual os atores, ainda sem ter que se responsabilizar por determinada função, poderiam exercitar a criação de textos e cenas, brincando com os diversos pontos de vista sobre a cena e sua composição.

Em outubro de 2007 iniciamos os trabalhos orientados. Tínhamos, eu e Cida Falabella, um encontro conjunto durante a semana, mas, em geral, trabalhávamos em dias separados, quando desenvolvíamos estratégias que possibilitavam a investigação prática da função pesquisada: dramaturgia ou direção. Especialmente no caso da dramaturgia, havia o desejo, por parte do Teatro Invertido, de que fosse abordada uma "teoria do drama ${ }^{30 "}$. Contudo, optei por trabalhar da prática para a teoria, não incorrendo no erro de buscar uma formação generalista de dramaturgia, que passasse, inclusive, pelo drama clássico e pela cena realista. Como já havia acompanhado o trabalho do grupo nos seus processos anteriores e já conhecia um pouco de sua linguagem, sabia que ela não passava, propriamente, pelo drama. Dessa perspectiva, não via sentido em aprofundar seu estudo. Além disso, como pesquisadora e

\footnotetext{
${ }^{29}$ GRUPO TEATRO INVERTIDO, op. cit., pg. 13.

${ }^{30}$ Como o grupo tem, em sua maioria, uma formação acadêmica e eu, por outro lado, sou professora de Dramaturgia do Departamento de Artes Cênicas da UFOP, parecia haver quase uma inclinação natural para esse enfoque.
} 
dramaturga, havia investigações que - sendo de meu interesse - dialogavam diretamente com o trabalho desenvolvido até então pelo Teatro Invertido.

Um elemento recorrente no trabalho do grupo e presente em toda a minha investigação como dramaturga, era a utilização da narrativa. A partir desse eixo, propus vários jogos que buscavam construir, por meio das relações entre ações desenvolvidas pelos atores e a manipulação de fragmentos textuais narrativos, materiais textuais diversos. Por intermédio desses jogos eu buscava, também, fazer com que os atores conseguissem localizar os elementos propriamente dramatúrgicos, como ação, núcleo de cena, actante.

Uma vez que o tema geral eram os cinco sentidos e, nesse momento, não havia delimitação de quem trabalharia com o que, propus que os atores partissem, então, de seus desejos e trouxessem materiais variados a partir do sentido que os tocasse mais. Esses materiais textuais poderiam ser desde bulas de remédio até notícias de jornal, narrativas literárias e depoimentos pessoais; e iam desde frases curtas até fragmentos de uma página inteira. As narrativas eram exercitadas de vários modos - sonoramente, em jogos com ações, em relações com objetos - e depois organizadas como experimentos cênico-dramatúrgicos propostos pelos atores. Posteriormente, era realizado um trabalho de reescrita do material apresentado, na tentativa de se produzir um texto acabado, ou, em outras palavras, uma proposta de dramaturgia concretizada textualmente e realizada cenicamente.

A teoria aparecia como suporte, advinda das questões suscitadas pelo trabalho. Muitas das questões trazidas pelo grupo giravam em torno dos procedimentos colaborativos, uma vez que, naquele momento, os atores exerciam todas as funções, conjuntamente. Nessa fase do trabalho, o ator era solicitado a propor individualmente uma cena que acabava sendo o gérmen do material que ele, ou outro ator, construía, posteriormente, como dramaturgo e como encenador. Às vezes, como no trabalho de edição textual, era solicitado que eles, em conjunto, construíssem o texto para, posteriormente, ser experimentado também em conjunto, na cena. Ou seja, eles eram os dramaturgos, diretores e atores das propostas cênico-dramatúrgicas produzidas. As dúvidas, então, se relacionavam, principalmente, à especificidade da função, pois, no entendimento deles, como não estava em questão uma posição individualizada de proposição e decisão em relação à dramaturgia, o que então, seria o elemento definidor 
dessa função dentro do processo? Para responder a essa questão, eu buscava exercitar com eles, justamente, as ferramentas de composição próprias da dramaturgia, a fim de ampliar o seu olhar sobre as possibilidades dramatúrgicas da cena e tentar diferenciálas da composição/olhar própria do encenador (mesmo que, evidentemente, as duas dimensões estivessem entrelaçadas). Ou seja, buscava exercitar a sintaxe e estruturação das cenas a partir de exercícios textuais, nos quais os núcleos de ação e as relações actanciais eram definidos não pelos jogos atorais ou pelos elementos plásticos da cena, mas pelas formalizações verbais e exploração dos elementos propriamente lingüísticos.

Outras questões giravam em torno das formas e eram, em geral, colocadas por mim. Como espectadora do trabalho realizado por eles, percebia uma formalização da dramaturgia que era estranha ao material proposto inicialmente por eles como atores. Este tinha um caráter narrativo e fragmentado. À medida que eles assumiam o lugar do dramaturgo, passavam a dar ao material um caráter mais dramático, buscando criar pontes entre os fragmentos por meio do desenvolvimento de uma ação dramática, baseada na noção do conflito. Estaria essa forma de apropriação da dramaturgia relacionada a uma visão de senso comum do que seria uma estruturação dramatúrgica, relacionando-a, necessariamente, com o cânone dramático? Ou advinha do pouco conhecimento do grupo de dramaturgias contemporâneas e de formas textuais que extrapolassem esse cânone?

A partir dessas questões, eram abordados diversos textos teóricos que permitiam, a partir de sua leitura e discussão, ampliar a visão do grupo sobre as possíveis formas a serem experimentadas no desenvolvimento do trabalho. Era uma fonte preciosa de investigação dramatúrgica, além da teoria, o contato com exemplos de dramaturgias contemporâneas ou pós-dramáticas, como textos de Gertrude Stein, Heiner Müller (do qual eles só conheciam MedeaMaterial), Bernard-Marie Koltès, Michel Vinaver e outros. A tentativa era fazer com que o grupo buscasse construir uma dramaturgia que correspondesse não só aos elementos de linguagem de seu interesse, mas, principalmente, às formas fragmentadas, narrativas, que o processo vivenciado por eles imprimia às cenas. No meu entendimento, o dialogismo presente em processos que, pela própria natureza do modo de produção, é polifônico, como é o caso do processo colaborativo, produz um texto escritural (BARTHES, 2004), no qual a ambigüidade, a subjetividade e a pluralidade predominam. Ou seja, na medida em que 
a escrita é projetada nas ações, corpos e espaços para ser lida e imediatamente reescrita, ela pode trazer, na superfície mesmo do texto, as marcas dessa projeção espacializada e corporificada.

A partir de fevereiro de 2008, começamos, efetivamente, os experimentos colaborativos em que cada ator exerceria as funções individualizadas de dramaturgia e direção, na construção de uma cena. Estava previsto um período de mais ou menos dois meses para o desenvolvimento de cada experimento. Nos cinco processos, o sentido escolhido acabou servindo não só como um ponto de partida temático, que despertava outros "sentidos" e associações, mas também como centro gerador de dinâmicas improvisacionais ou de jogos de atuação que primavam o aspecto sensorial. Esses procedimentos acabaram por determinar, de certo modo, o rumo que o material cênico tomava.

No primeiro processo, o tema Audição foi ponto de partida para todo o trabalho de aquecimento vocal e corporal dos atores. Camilo Lélis assumiu a direção, Rogério Araújo, a dramaturgia, mantendo-se, como atores, Rita Maia, Leonardo Lessa e Kelly Crifer. Percussão corporal, manipulação de instrumentos sonoros inusitados, trabalhos com o silêncio, além de laboratórios em espaços como o Mercado Central - repleto de ruídos - e o cemitério, foram sugeridos tanto da parte da direção, como da parte da dramaturgia. Pelo próprio caráter musical de sua formação, o dramaturgo responsável, Rogério Araújo, acabou se incumbindo do treinamento corporal dos atores, em um primeiro momento. Percebia que isso o desviava da investigação em torno da própria função e propus a ele que tentasse aprofundar o uso dos elementos sonoros, pensandoos como elementos de composição dramatúrgica.

Embora uma boa parte da pesquisa desenvolvida estivesse centrada na sonoridade, os improvisos dos atores apontavam para as possibilidades temáticas, advindas do desdobramento de possíveis significados relacionados à audição, e questões concernentes à incomunicabilidade e à falta de escuta apareceram, nas improvisações, de maneira recorrente. Apesar do caráter claramente fragmentado do material cênico surgido daí, a resultante cênica acabou adquirindo uma tonalidade dramática, em função da opção de se desenvolver uma linha narrativa centrada no conflito amoroso de um casal. A história do casal era cortada pela trajetória da atendente de um serviço de auxílio a casais, com quem eles, em busca de soluções para 
seus problemas, travavam diálogos absurdos. Contudo, muitos aspectos interessantes estavam presentes na estrutura de Diálogo Interrompido, como a alocução ao público, o "diálogo de surdos" e a simultaneidade.

Ela: Ele nunca me diz o que ele faz. Seu marido diz o que ele faz? É pelo canto que se conhece a ave. Guarda-te do homem que não fala e do cão que não ladra. O que você comeu no almoço? (Espera a resposta)

Ele: Ela não entende que ele precisa de inspiração para ouvir as palavras mais essenciais. Ela não escuta a necessidade do silêncio. Quem fala demais dá bom dia a cavalo.

Ela: Ouviu? Nada! Eu tô falando pras paredes. Não tem nada. É só silêncio. Não tem música.

Ele: Pelo canto se

Ela: (cantando)

conhece a ave.

Cartas já não

Temos dois adiantam mais.

ouvidos e apenas

Quero ouvir a sua

uma boca para

voz. Vou telefonar

ouvirmos mais do

dizendo que eu

que falarmos.

estou quase

Palavras bem ditas

morrendo de

tornam-se

saudades de você.

malditas.

Eu te amo, eu te

amo, eu te amo...

Ela: Alguém pode me dar ouvidos?

Atendente Solitária: Ouvidos. Órgãos relacionados como equilíbrio e com a audição, evoluem a habilidade da escuta e ativam o exercício da fala. Estimulam a conquista e prática da flexibilidade física, emocional, psíquica e comportamental, e incentivam o desenvolvimento e a apropriação dos sentidos de verticalidade, horizontalidade e de direção, essencial no processo de definição e organização dos projetos de vida ${ }^{31}$.

Na avaliação final desse processo, bem como nas discussões que permearam toda a criação, as questões levantadas pelo grupo estavam relacionadas,

\footnotetext{
${ }^{31}$ ARAÚJO, Rogério. Diálogo interrompido. Trecho do roteiro dramatúrgico de 22 de março de 2008 (material inédito).
} 
principalmente, com o funcionamento de um processo colaborativo e, de modo bastante específico, com os limites de responsabilidades e decisões de cada função. Questões concernentes aos encaminhamentos próprios de cada função, ao tempo que deveria ser gasto na improvisação e seleção do material e à responsabilidade dessa seleção (além dos critérios que a definiriam), bem como aquelas referentes ao planejamento dos ensaios e às proposições dos pontos de partida para as improvisações. Em relação à dramaturgia, as dúvidas estavam relacionadas à forma que as proposições deveriam ter, ou seja, se o dramaturgo deveria propor imagens, ações dramáticas, cenas fechadas ou narrativas que servissem de ponto de partida.

Segundo Antônio Araújo (ARAÚJO, 2002), no processo colaborativo, busca-se garantir a autonomia das funções artísticas. A partir dessa premissa, é possível pensar quais seriam as especificidades das funções "ator", "diretor" e "dramaturgo", considerando-as como tríade básica do trabalho de criação da cena. Já de antemão, posso dizer que nos processos de criação colaborativa, como é salientado por ele, é de extrema importância que os colaboradores/criadores, independente da função ocupada por eles, sejam partícipes para que, de fato, “ocupem” um lugar na criação. Um dramaturgo não-propositivo certamente não deixará marcas no texto e em sua estrutura, tornando-se apenas um "escriba”, um organizador do material criativo produzido por outros. Do mesmo modo, um ator que não se coloque como criador, interferindo nos diversos níveis do discurso da cena - inclusive nas decisões de nível mais geral - continuará sendo um joguete dos demais. Em relação ao papel do ator na criação, Antônio Araújo afirma:

Pois, se dramaturgo e diretor necessitam sempre transitar do fragmento ao todo e do todo ao fragmento, por que seria diferente com os atores? Esse modelo de um ator que mergulha cegamente em uma personagem, se alheando ou pouco se interessando pelo discurso geral da peça, nos parecia obsoleto e limitador. O mesmo podendo ser dito em relação aos outros colaboradores artísticos (...). Todos eles, apesar de comprometidos com determinado aspecto da criação, precisariam integrar-se numa discussão de caráter mais generalizante. Em outras palavras, um ator não cria apenas um personagem, um iluminador não cria somente o seu projeto de luz, um sonoplasta não cria unicamente a 
trilha do espetáculo, mas todos eles, individual e conjuntamente, criam a obra cênica total que será levada a público ${ }^{32}$.

Quanto ao encenador, no processo de criação colaborativa ele não funciona mais como eixo central na concepção dos espetáculos, perdendo a posição de autoridade e organização do todo que lhe é outorgada nos processos tradicionais. No entanto, ao longo dos cinco processos vivenciados durante o desenvolvimento do projeto Ator Invertido, cinco sentidos para a construção da cena, foi possível perceber, em maior ou menor grau, uma postura ainda atrelada à visão tradicional do diretor, como organizador dos ensaios, como definidor dos espaços de criação dos outros colaboradores. Ou essa postura vinha dos atores, que outorgavam ao diretor - bem como ao dramaturgo - um lugar de autoridade, ou do próprio diretor, o qual assumia uma carga de responsabilidade maior, como se os erros e acertos do processo fossem devidos a ele.

No segundo processo, o tema do olfato gerou os procedimentos de criação e improvisação, pautados nas sensações ligadas ao cheiro e à memória do cheiro. Nesse processo, atuaram Rogério Araújo, Kelly Crifer e Camilo Lélis, tendo Leonardo Lessa assumido a dramaturgia e Rita Maia, a direção. A partir dos direcionamentos tanto da dramaturgia como da direção, as improvisações foram caminhando, cada vez mais, para o campo da memória. Como os materiais cênicos propostos pelos atores giravam em torno de uma infância idílica do interior, freqüentemente o campo dos olfatos abarcava somente os olfatos agradáveis e as cenas acabavam por adquirir um tom poético. É exemplar a cena produzida pela atriz Kelly Crifer.

Atriz (sentada no banco) - O menino foi encontrado depois de 12 dias. O corpo estava boiando nas beiras do Rio e exalava um cheiro forte. (musiquinha - solfejo. Atriz dá uma volta ao redor do rio - papel - flor. Corre) - eu vou chegar primeiro! (senta se no banco novamente). Era um dia de goiabas vermelhas. Uma cambada de crianças saía correndo nas areias do Rio Jequitinhonha. As goiabas caiam ploft! Desabrochando o vermelho e o cheiro exalava tão forte que chegava na casa dos meus tios avós. E aí era uma correria só. (faz um barquinho de papel). Todas

\footnotetext{
${ }^{32}$ ARAUJO, 2002: 103.
} 
tinham um pontinho preto - bicho de goiaba não faz mal, faz bem pra saúde e também, se não matar, engorda! Marcelo morreu afogado no Rio Jequitinhonha num dia de goiabas vermelhas. (canta a música - lá vai o meu barquinho e solta o barco $)^{33}$.

O dramaturgo, Leonardo Lessa, resolveu fazer uma provocação, que acabou indicando a linha dorsal do texto: para ele, era necessário falar do que cheirava mal. A partir desse apontamento, várias questões relacionadas ao aspecto metafórico da pergunta "o que cheira mal pra você?" se apresentaram. Muitas, em oposição à visão idílica do das cidades do interior e da infância, diziam respeito aos problemas dos grandes centros urbanos e se relacionavam, inclusive, com os cheiros concretos que a cidade produzia: poluição, sujeira, podridão. Colocando em relação esses dois elementos - o passado idílico e o caos urbano - chegaram à cena Essência.

Na resultante cênica, o desenvolvimento da linha narrativa se dava por meio da memória, ativada pelos cheiros que povoavam a cena, e de recursos épicos, como o flash back. Essência contava a história de um menino que sai da roça e vai para a cidade grande, perdendo seus cheiros e sua identidade. Os cheiros acompanhavam sua trajetória e iam se degradando até a cena final em que ele, já mendigo, expulsava o público em função do terrível cheiro que seu corpo exalava.

Um homem vem da rua trazendo nos braços uma mala. No nariz um pregador de roupa. Aproxima-se do público, sente-se um forte cheiro de naftalina que vem das roupas dele. Ele abre a porta e conduz as pessoas para o interior do espaço. Cheira a própria roupa, a parede, o banco onde está sentado e reage como se não sentisse o odor das coisas. Ele pega um pequeno caderno e uma caneta. Começa a escrever. (...) Escuta-se uma voz feminina que narra o que ele escreve.

MÃE - Diário, escrevo para dizer do sentido que me foi roubado. Furtaram meu direito de exercê-lo, como tantos outros. Hoje falo pelo nariz, essa parte osso e cartilagem que divide meu rosto ao meio. Companheiro de memória, ele me fala da saudade que sinto de lá. Minha família... Minha terra. ( $O$ homem abre uma mala, dela retira pequenos sacos envolvendo temperos e objetos.)

33 CRIFER, Kelly. Material textual retirado dos relatos de processo que produzi durante o desenvolvimento do projeto. 


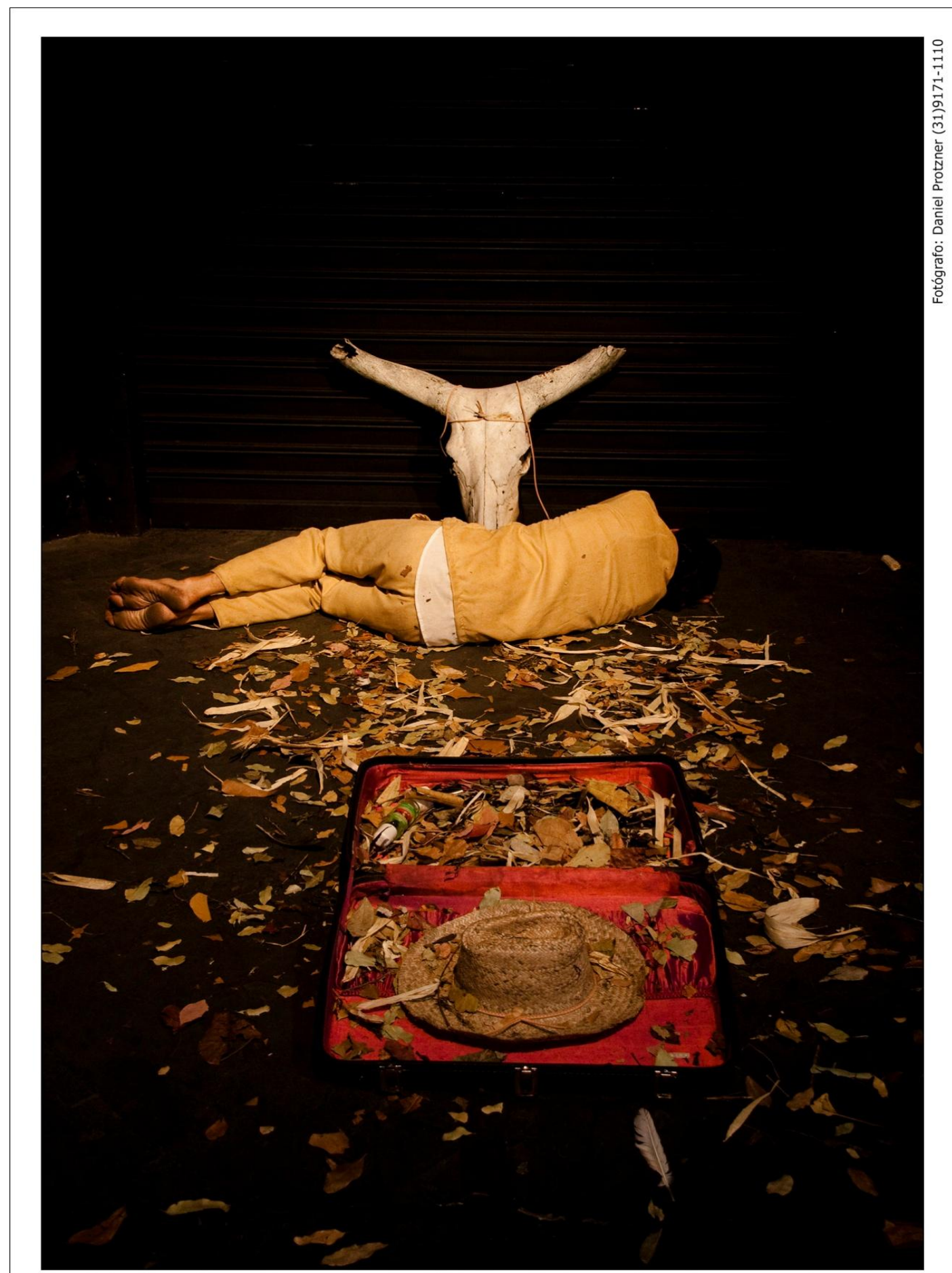

"Proibido retornar" - Grupo Teatro Invertido (Belo Horizonte/MG) / Local: Esquyna Espaço Coletivo Teatral FIG. 07

HOMEM - Vou, na medida do possível, temperando minha vida aqui. Nessa terra de concreto, sou obrigado a tragar esses ares hostis dessa gente sem tempero. Por aqui, só importa o "tato": pagar e receber. Prata, ouro, bronze, diamantes... Que cheiros têm? (...) (Ele se dirige à 
platéia, a luz vai caindo lentamente. Penumbra total. Ele abre um pequeno saco e leva seu conteúdo até o nariz de cada espectador.)

Cânfora com mentol: - Eu, um menino sempre com o nariz entupido.

Creme Nívea: - Minha Avó.

Fumo de rolo: - Meu Pai.

Leite de rosas: - Minha Mãe... Meus cheiros têm história ${ }^{34}$.

Nesse processo, foi clara a comunhão que havia entre dramaturgo e diretora, os quais trabalharam, muitas vezes, em parceria e numa linha tênue entre os limites e funções de cada um. Os limites da atuação de cada função foi tema da avaliação desse processo de trabalho, bem como as relações de criação e interferência das orientadoras no trabalho.

No terceiro processo, centrado no tato, as improvisações se concentraram em algumas dicotomias percebidas pelo grupo: o tato está associado ao prazer e à dor, ao amor e à tortura. Nele, assumiu a dramaturgia Camilo Lélis, ficando a direção por conta de Kelly Crifer. Inicialmente pensado para o exercício de três atores, o processo acabou tendo que tomar outros rumos de criação devido à saída de Rogério Araújo, por questões de saúde. Em termos, por exemplo, da linha temática pensada pela dramaturgia, muita coisa se alterou. A questão do afeto que, anteriormente, estaria ligada à relação entre os dois homens foi transformada na discussão entre o afeto e o abuso sexual e a cena resultante foi centrada no jogo de investigação policial realizado pelos dois atores, Leonardo Lessa e Rita Maia.

O jogo era o mote para se contar a história de uma menina, Lúcia, presa e abusada pelo pai. Nesse processo, foi intensificada a relação com o espectador, que já se apresentava na cena anterior por meio dos cheiros. Em falsa ocorrência, alguns espectadores eram convidados a dançar e a compor a cena e, no decorrer dela, o público chegava a ser tocado pelo ator, Leonardo Lessa. Além disso, eram exploradas quebras, passagens entre a instância do ator e a do personagem, ou seja, os atores

\footnotetext{
34 LESSA, Leonardo. Essência. Trecho do texto final: cena inicial do espetáculo (material inédito). Posteriormente, essa cena foi retrabalhada e transformou-se no espetáculo Proibido Retornar, cuja dramaturgia é parte integrante do livro Cena Invertida: dramaturgias em processo, publicado pelo grupo em parceira com o Centro de Pesquisa e Memória do Teatro, do Galpão Cine Horto (GRUPO TEATRO INVERTIDO, 2010).
} 
transitavam da dimensão ficcional da cena para a instância de construção da cena, como atesta o trecho abaixo.

(O Baile - Música).

Lúcia: Dança comigo.

Policial 1: Você mora aqui perto? Nunca percebeu nada de estranho nessa casa?

Policial 2: Você ficou sabendo dessa história? Ficou claro que ela é apaixonada por Fernando até hoje? Você estava aqui quando levaram o pai, algemado?

Policial 1: Qual o seu nome? O pai se fazia passar por Fernando, você entendeu essa parte?

Policial 2: Obrigado, pelo depoimento.

Policial 1 : Obrigado, pelo depoimento.

(Escuro)

Policial: (Ao centro com a luva e lanterna. Essa é uma cena muda, em que o policial toca as pessoas $)^{35}$.

Novamente as relações entre os criadores, bem como limites e atitudes propositivas foram tema de discussão, principalmente no que concerne ao campo da seleção de materiais e rumos dos sentidos da cena.

$\mathrm{Na}$ análise dos processos eram perceptíveis os aspectos levantados por Santiago García $^{36}$ (ver primeiro capítulo da presente tese) em relação à criação coletiva, os quais evidenciam que a divisão de funções resulta, numa criação cênica compartilhada, de uma constante prática e reflexão no interior dos próprios coletivos teatrais que a praticam. No caso do projeto desenvolvido pelo Teatro Invertido, em que cada cena encontrava uma nova configuração da equipe de trabalho, a experiência dos processos anteriores, bem como a avaliação que era feita a cada núcleo e resultado apresentado, lançava questões a serem experimentadas no processo seguinte. Esse acúmulo de experiência era percebido, por exemplo, nas opções de treinamento e estímulos para a criação dos atores que adquiriam maior complexidade, a cada novo processo, na

\footnotetext{
${ }^{35}$ LÉLIS, Camilo. Falsa Ocorrência. Trecho do texto final (material inédito).
}

${ }^{36}$ GARCIA, 1988, pp. 27-39. 
medida em que os sentidos perceptivos desenvolvidos nas cenas anteriores eram incorporados ao trabalho em desenvolvimento.

No quarto processo vivenciado pelo Teatro Invertido, o tema sorteado, paladar, norteou os exercícios que alimentariam a criação dos atores: Camilo Lélis, Kelly Crifer e Leonardo Lessa. Nele, Rita Maia assumiu a dramaturgia e Rogério Araújo a direção. Já no primeiro encontro com a orientação, Rogério Araújo colocou que gostaria de trabalhar com um registro cômico, em função do peso dramático das cenas anteriores. O cômico pretendido, segundo ênfase do diretor, deveria seguir a mesma linha do primeiro espetáculo do grupo, Nossa Pequena Mahagonny, ou seja, deveria primar pela potência crítica. Esse aspecto foi reforçado pelos atores, que temiam cair numa “comédia digestiva”.

Quanto à dramaturga, Rita Maia, o interesse era principalmente temático, baseando-se na exploração do binômio banquete/fome. Sugeri, então, para ele, a leitura de Cultura Popular na Idade Média e no Renascimento, de Bakhtin, a fim de que ele pudesse levantar imagens e possibilidades de manipulação do cômico por meio do grotesco; e, para ela, a leitura de O Riso, de Bergson, com a finalidade de instrumentála em relação aos recursos dramatúrgicos do cômico. Como artista que tem em sua bagagem amplas relações com o sonoro, Rogério, optou, ainda, por convidar o músico André Veloso para trabalhar como criador colaborativo e propor o desenho de som da cena. A entrada de Veloso no processo de criação se mostrou importante para o desenvolvimento do trabalho.

Duas questões ligadas ao tema - "você tem fome de quê?" e "A gente é o que consome" - foram quase imediatamente levantadas e ajudaram a orientar - juntamente com o registro cômico, desejado pelo diretor, e com os estímulos ligados ao exercício do paladar - a produção do material cênico. Como nos três primeiros núcleos, a organização dos ensaios era dada pela direção e parecia quase "natural" que a concepção do processo fosse de responsabilidade do diretor. Como parecia natural a idéia de que a criação, partindo dos atores, tornasse legítima a idéia do coletivo.

Neste processo, embora os atores encontrassem bastante liberdade e o material cênico não tenha demorado a surgir, de algum modo ele parecia, na minha percepção, um tanto "domesticado". Já tendo experimentado três processos anteriores, o grupo tendeu a uma adequação, a um modelo harmônico do processo colaborativo, 
investigando menos cada função, o que, a meu ver, acabou se refletindo na resultante cênica. A cena, A refeição, mantinha um cômico bem comportado, pouco explorando as possibilidades críticas de uma estética grotesca, apontadas, de início, como de interesse do grupo. Apesar disso, ela propunha uma interessante relação com o público, que era convidado a participar do banquete-terapia.

- Doutor: Sim, é verdade. Você precisa colocar tudo para fora! (Pega um prato simulando um espelho) Eu quero que você olhe para o espelho. $\mathrm{O}$ que você vê?

- Mulher: Uma mulher gorda, imensa, uma baleia!

- Doutor: Hummm... Você anda comendo alface, não é mesmo? (Vai colocando folhas de alface em sua boca enquanto fala) Você quer ficar igual à Gisele Buchen?! Quer fazer uma cirurgia de lipoaspiração? Colocar um pouco de botox? Aposto que você quer ficar loura. Tem vários produtos de beleza na sua casa. A perfeição sempre sonhada. Modelos magras, poderosas, sensuais, perfeitas. (A atriz vomita a alface) Coloque isso pra fora! Se liberte! Coloque para fora aquilo que te ofende, aquilo que te humilha, aquilo que te diminui. Você é uma mulher bonita! A partir do momento em que você se separa da Gisele Buchen, você se reencontra. Diga para si mesma: Eu não sou um produto! Eu tenho identidade! Eu sou livre!

E então, como você se sente?! ${ }^{37}$

Houve o questionamento, na avaliação realizada, do papel criativo exercido pela dramaturga nesse processo. Havia a avaliação de que Rita Maia tinha funcionado menos como propositora, tendo agido mais como organizadora do material criado pelos atores. Decorrente dessa, apresentou-se, novamente, a discussão sobre a investigação das relações colaborativas, cerne da pesquisa realizada pelo grupo. A discussão era concernente, principalmente, às formas de composição próprias de cada função, sua relação com a concretização cênica por parte dos atores e, oriunda desta, a relação entre a ação/criação do ator e sua atuação como veículo da criação da proposta do outro. Foi ressaltada mais uma vez a necessidade de estudo da própria função e de

\footnotetext{
${ }^{37}$ MAIA, Rita. A refeição. Trecho do texto final (material inédito). Posteriormente, essa cena foi retrabalhada, transformando-se no espetáculo Estado de Coma, cuja dramaturgia também faz parte de Cena Invertida: dramaturgias em processo (GRUPO TEATRO INVERTIDO, 2010).
} 
uma avaliação crítica que fosse mais centrada no estudo de si e do desenvolvimento de ferramentas próprias. Tal ponto tocou também na importância de se aprofundar a pesquisa de linguagem, tanto por parte dos atores e diretor, como do dramaturgo e do músico. Como tensionar a relação entre os diversos elementos presentes na cena e a relação desta com o texto?

Já no quinto e último núcleo, centrado em torno da visão, a questão suscitada anteriormente deu margem a uma maior atuação por parte da dramaturgia, assumida por Kelly Crifer. A direção foi assumida por Leonardo Lessa e a atuação por Rogério Araújo, Rita Maia e Camilo Lélis. Remanescente da experiência anterior, André Veloso continuou assumindo o desenho de som da cena. Nesse processo, devido à agenda do grupo, os encontros foram mais esparsos e houve, por parte da direção, uma concentração maior de decisões e, por parte da atuação, maior resistência. Nesse sentido, a relação criativa, tensionada pelas relações de poder, entrou em discussão tanto por meio da postura de resistência em relação à proposta do outro como de uma postura de alheamento em relação às decisões ou tomadas de posição por parte dos atores, no que dizia respeito à criação e às relações colaborativas.

A relação proposta para o público na construção das cenas e, em particular na construção da última, suscitou para o Grupo Teatro Invertido uma discussão em torno do formato das mostras que ocorriam ao final de cada experimento de cena e do sentido delas dentro de um processo de pesquisa. As principais questões eram: $\mathrm{O}$ que é possível ser "apresentado"? Como mostrar o processo de pesquisa, quando seu cerne é a pesquisa das relações e procedimentos que alavancam uma criação colaborativa e não o material cênico produzido? Como mostrar um processo de criação em colaboração?

$\mathrm{Na}$ avaliação realizada após a mostra da resultante cênica do trabalho desenvolvido, as questões mais fortes giraram em torno da percepção de cada um dos criadores no que diz respeito ao desenvolvimento e às "evoluções" das relações colaborativas. Tal percepção levou o grupo a questionar se há um "modelo ideal” de processo, do qual se poderia falar em termos de avanços ou retrocessos, mas também a perceber as estratégias e dinâmicas que tinham auxiliado na construção de uma relação de colaboração.

Ainda ligada à questão do processo, a discussão em torno do papel de cada função e sua relação com as instâncias do poder e das hierarquias continuou em pauta, 
bem como a investigação da função como forma de composição específica. Nesse núcleo, como a dramaturgia assumiu um papel mais propositor, entrou em xeque, ainda, a relação entre o desenvolvimento da dramaturgia - ou seja, a pesquisa da função - e o desenvolvimento de uma dramaturgia de cunho dramático. A relação dos atores com o material dramatúrgico, bem como a necessidade de improvisação do dramaturgo e da improvisação dos outros criadores sobre esse material, também encontraram foco.

No que concerne especificamente ao trabalho desenvolvido pelos dramaturgos nos experimentos resultantes do projeto Ator Invertido, cinco sentidos para a construção da cena, percebo que o grupo ainda está amarrado a uma visão da dramaturgia como um trabalho de estruturação da fábula e de trajetórias de personagens. Nesse último processo, por exemplo, o material levantado inicialmente apontava para um texto fragmentado e com incursões de narrativas mais fortes do que o resultado dramatúrgico apresentado. Nesse sentido, a questão que, a meu ver, subsiste e da qual os processos vivenciados pelo grupo, no desenvolvimento do projeto, parecem não ter dado conta, refere-se à garantia, na superfície do texto mesmo, do cruzamento de vozes presentes na sala de ensaio, ou seja, concerne à investigação de procedimentos que possam tornar possível à dramaturgia, como fruto de uma experiência de colaboração, fazer-se polifônica. 
Romper a linguagem para tocar na vida é fazer ou refazer o teatro Antonin Artaud 


\section{A rede colaborativa obscênica: dramaturgias no corpo da cidade}

\subsection{Coletivos e redes de colaboração}

A percepção de que uma atuação política e social está intrinsecamente relacionada à atuação artística parece ser constituinte dos coletivos de arte. As formas de atuação variam e vão de práticas bastante amplas, como a discussão e ocupação de espaços públicos, a outras mais específicas, como o oferecimento de oficinas de formação artística para populações menos privilegiadas, tais como operários, semterras ou detentos, prática bastante comum, por exemplo, aos grupos teatrais. Embora o grupo de teatro seja, em geral, o modo de agrupação mais comum aos coletivos que trabalham com artes cênicas, é perceptível, atualmente, que muitos deles vão buscar formas de organização e atuação - tanto artística quanto política - que escapam dessa denominação.

A própria idéia de "coletivo" já denota uma mudança de perspectiva em relação ao modo de estruturação grupal. Segundo Verônica Gonçalves Veloso', a principal característica do grupo teatral é a estabilidade temporal, ou seja, a "formatação duradoura" do "conjunto de pessoas com interesses comuns" que o constitui, a partir do modelo dos grupos estáveis de longa vida, como o Grupo Galpão - com quase 30 anos de existência - e a Tribo dos Atuadores Ói Nóis Aqui Traveiz, com 33 anos de estrada. Emprestando o termo das artes plásticas - campo no qual é usual a reunião temporária de artistas que, a partir do que Veloso chama de “empreitadas”, ou seja, de um foco de interesse (um tema agregador ou um local a ser ocupado), desenvolvem um trabalho conjunto - os coletivos de artes cênicas teriam como característica, justamente, um modo de organização mais dinâmico e flexível, tendendo à efemeridade e ao nomadismo, como é perceptível na forma de estruturação proposta por alguns coletivos atuantes em Belo Horizonte, tais como o Conjunto Vazio, o VagoColetivo, Os Conectores, o N3Ps e o Obscena.

\footnotetext{
${ }^{1}$ VELOSO, Verônica Gonçalves. Grupo ou coletivo: uma questão de tempo IN: Anais do V Congresso da ABRACE: criação e reflexão crítica, Belo Horizonte, 28 a 31 de outubro de 2008.
} 
O N3Ps - Núcleo Permanente de Pesquisa e Performance ${ }^{2}$, por exemplo, se define como "uma equação disjuntiva de conjunto, uma usina de produção desejante" que "reúne performers-pesquisadores com propostas de pesquisas que se desenvolvem independentes e sobrepostas, predispostas aos deslocamentos, deslizamentos e às contaminações ${ }^{3}$. Já o Obscena ${ }^{4}$ - agrupamento independente de pesquisa cênica que é objeto de estudo do presente capítulo - pode ser considerado, do mesmo modo, um exemplo de organização coletiva não grupal, apesar de ter muitas das características de um teatro de grupo que são salientadas por André Carreira ${ }^{5}$, como a defesa da autonomia de criação e a continuidade no trabalho de pesquisa, além da atuação junto a determinados segmentos sociais ${ }^{6}$. O Obscena, no entanto, busca resistir ao formato de grupo e à construção de uma identidade grupal. Nesse sentido, o agrupamento vai propor uma nítida distinção em relação ao modo de organização dos grupos teatrais, funcionando como uma "rede colaborativa de criação e investigação teórica e prática sobre a cena contemporânea ${ }^{7 ”}$. Na prática, isso significa dizer que o agrupamento - ao se constituir como uma rede de pesquisadores autônomos que dialogam suas pesquisas e materiais de modo colaborativo, buscando "instigar a troca, a provocação e a experimentação artísticas" - pretende criar "possibilidades de expansão da rede" por meio de encontros "com outros artistas, órgãos e movimentos sociais de interesse"

Esta, aliás, parece ser uma característica dessas novas formas de agrupação: a mobilidade das redes. Diferentemente dos grupos de teatro, os quais parecem ter um caráter mais identitário e "fechado" ou, até mesmo, "familiar", esses coletivos tendem a

\footnotetext{
${ }^{2}$ Fundado pela pesquisadora Clarissa Alcântara durante o período em que lecionava disciplinas de Interpretação e Performance no Curso de Artes Cênicas da UFOP, o núcleo é integrado por Clóvis Domingos, formado em Direção Teatral na UFOP e por Matheus Silva e Nicolas Lopes, formados pelo Curso de Licenciatura em Artes Cênicas da UFOP.

${ }^{3}$ Conforme http://nzps-pesquisaperformance.blogspot.com (acesso no dia o6/o2/2011).

${ }^{4}$ Fundado em 2007 por mim e pela atriz Lissandra Guimarães, o Obscena é integrado, ainda, pelos artistas pesquisadores Saulo Salomão, Clóvis Domingos, Erica Vilhena e Joyce Malta. Em 2010, agregaram-se a ele os performers-pesquisadores Matheus Silva, Davi Pantuzza, Leandro Acácio e Viviane Ferreira.

${ }^{5}$ CARREIRA, André. Teatro de Grupo: diversidade e renovação do teatro no Brasil IN: Subtexto: Revista de Teatro do Galpão Cine Horto. Belo Horizonte: Edições CPMT, ano IV, no 4, nov 2007, pp. 8-11.

${ }^{6}$ Isso talvez se deva ao fato do agrupamento ser composto por artistas que, em sua maioria, são oriundos de grupos de teatro, com experiência e formação em grupos.

${ }^{7}$ Conforme www.obscenica.ning.com (acesso no dia 06/02/2011).

${ }^{8}$ Ibidem: grifos meus.
} 
conexões que podem ser chamadas de "rizomáticas", incluindo a mobilidade de seus integrantes e a porosidade das relações com outras redes, mas também a ampliação de suas relações de troca e a disseminação do pensamento produzido pelos coletivos. Tal disseminação se dá, muitas vezes, via internet, sendo comuns, em seus blogs, postagens que tanto relatam experiências realizadas, como propõem ações a serem feitas, disseminam imagens, constroem projetos e apontam vias teóricas. O que parece ser outra de suas características: o interesse em um aprofundamento teórico que propicie não somente a sistematização de procedimentos e resultados relativos ao próprio trabalho artístico, mas também a construção de uma reflexão crítica expandida que, aliada à sua atuação política, permita uma coletivização dos saberes. Há, aqui, uma clara idéia de "desautoria", como atesta o aviso que abre o verbete Plágio ${ }^{10}$, produzido pelo Conjunto Vazio a partir da apropriação de vários textos e no qual não existe designação nenhuma de autoria, por parte de quaisquer dos integrantes do coletivo: “Assim como esse texto é constituído por plágios, qualquer trecho ou o texto inteiro, é livre para ser copiado”.

Esses coletivos vão, além de propor diferentes formas de organização - redes colaborativas, programas, conjuntos, núcleos independentes - investigar linguagens que extrapolam, em muito, o que é chamado, de modo mais estrito, de teatro, transitando nas fronteiras entre as artes cênicas e as artes plásticas, entre a performance, a instalação e a intervenção urbana. Evidentemente, não só a diluição das fronteiras entre as artes não é uma novidade - pois data de mais de um século, tendo se iniciado com as vanguardas históricas - como o próprio conceito de performance vai abarcar, em certo sentido, a arte que quebra paradigmas e fronteiras e transita entre os campos já mencionados acima. Além disso, é sabido que, mesmo dentro do teatro contemporâneo, essas fronteiras, no que se refere "à experimentação de novas formas

\footnotetext{
${ }^{9}$ Aos sistemas centrados (como árvores ou raízes), Deleuze e Guattari contrapõem os rizomas: sistemas descentrados, redes nas quais a comunicação se faz de uma linha a outra linha qualquer, em que qualquer ponto pode (e deve) ser conectado a outro ponto qualquer e nas quais as linhas, pontos, coisas, são todos intercambiáveis e se definem somente por um estado momentâneo, de tal modo que as operações locais se coordenam e resultam numa sincronia final que independe de uma instância central, como os fios de uma marionete que, consideradas como rizoma, não remetem à vontade do artista manipulador, mas à multiplicidade das fibras nervosas que podem, por sua vez, formar outra marionete. DELEUZE, Gilles \& GUATTARI, Felix. Mil Platôs: Capitalismo e Esquizofrenia. Vol. 1. São Paulo: Editora 34, 1995.

${ }^{10}$ CONJUNTO VAZIO. Verbete 7: Plágio IN: vocabulário de palavras em desuso, disponível em http://comjuntovazio.wordpress.com/2011/02/ (acesso no dia: 08/03/2011).
} 
cênicas ou do uso do espaço cênico ${ }^{11 "}$, têm se esgarçado e se ampliado, na medida em que a "multiplicidade de discursos teatrais e até mesmo a proximidade com as experimentações oriundas do campo das artes plásticas parece haver explorado todas as possibilidades de reorganização dos discursos do espetáculo teatral”, como ressalta André Carreira (2003: 21). Nesse sentido, parece contraditório afirmar a distinção entre os grupos teatrais e as novas formas de agrupação coletiva a partir de suas escolhas poéticas.

Contudo, essa assertiva está relacionada com o fato, que também me parece evidente, de que essa diluição de margens não afetou a unidade mínima do fenômeno teatral, o espetáculo, mesmo que este seja constituído, como afirma Sílvia Fernandes ${ }^{12}$, a partir de processos de criação teatral que se desdobram em "mecanismos de intervenção direta na realidade”, os quais podem chegar a adquirir autonomia e funcionar como "microcriações dentro do projeto maior de trabalho" ou como "manifestações híbridas, em que as pesquisas da cultura e os jogos do ator adquirem igual ou maior importância que a resultante especificamente cênica”. É o caso, por exemplo, dos espetáculos produzidos em processo colaborativo pelo Teatro da Vertigem, nos quais a "migração do teatro do palco para a cidade" é explicitada pela "fragmentação cênica que funciona como mimese exata da fratura social" (FERNANDES, 2010: 84). Por outro lado, parece-me que as formas de organização coletiva de que trato aqui vão propor modos de atuação que não só ultrapassam os limites territoriais e autorais, mas que, também, colocam em xeque a noção de obra de arte.

É importante perceber que, muitas das discussões e ações realizadas em torno das possibilidades políticas da arte (de forma alguma exclusivas dos coletivos), são concretizadas no campo da forma e problematizam o conceito de representação, ao se constituir, muitas vezes, no plano do estranhamento e da experiência mais do que como objeto artístico ou obra. Visam, assim, criar frestas para uma ação microscópica e pontes para a atuação, não do espectador ou do fruidor - pois questiono se é possível

\footnotetext{
${ }^{11}$ CARREIRA, André. Performance teatral e risco físico: construção de vínculos e exploração de margens IN: CARREIRA, André et al. (org.). Mediações performáticas latino-americanas. Belo Horizonte: FALE/UFMG, 2003, p. 21.

${ }^{12}$ FERNANDES, Sílvia. Teatros do Real IN: FERNANDES, Sílvia. Teatralidades Contemporâneas. São Paulo: Perspectiva, 2010, pp. 83-86.
} 
falar de público, nesses casos - mas do cidadão. É exemplar o trabalho Trajeto para Hélio ou uma coreoHeliogeografia, do performer e arquiteto Maurício Leonard ${ }^{13}$.

Segundo o próprio Maurício, a intervenção partiu de uma imbricação entre geografia, biologia e biografia. Ela consistiu em espalhar sementes de Girassol pelos canteiros e jardins de um bairro da cidade com pequenas etiquetas colocadas na terra ou nos brotos anunciando que ali havia Girassóis brotando e pedindo para que as pessoas cuidassem. Depois que os Girassóis cresceram, iniciou-se a criação de diversas lendas e histórias das pessoas que tentavam dar um sentido para a existência daqueles Girassóis que, misteriosamente, cresciam em frente às suas casas ou em seus jardins particulares.

A intervenção proposta pelo artista vai se concretizar, de fato, a partir das ações realizadas pelo conjunto dos moradores do bairro, não só ao cuidar das mudas, mas também ao constituir uma espécie de tecido de suas narrativas sobre os girassóis. Esse aspecto microscópico e a linha tênue que, na performance, separa (ou alinhava) a arte e a vida está bastante presente também na obra e no pensamento de consagrados artistas plásticos, como Lygia Clark ou Artur Barrio, que, em diversos trabalhos denominados por ele como ações/situações - construía a “obra” na relação com a cidade e com o transeunte ${ }^{14}$. É exemplar desse caráter público de suas interferências, o Trabalho Processo 4 DIAS 4 NOITES, no qual Barrio caminhava pela cidade do Rio de Janeiro e criava o "estado da arte" a partir do estado alterado de seu corpo.

Esse trabalho processo começou a partir do Solar da Fossa onde eu morava, então saí a pé às cinco horas da manhã passando pela Ladeira

\footnotetext{
13 Trabalho comentado pelo filósofo e pesquisador da cena contemporânea Davi Pantuzza: www.davipantuzza.blogspot.com (acesso no dia 06/02/2011).

14 "Existe, portanto, uma outra via dupla nesse trabalho, que é a tentativa de simbiose entre o papel individual do artista - a carga compulsiva de sua ação sobre o mundo - e a sua função no corpo coletivo das sociedades. [...] O trabalho de Barrio nesse sentido, tinha um alcance muito amplo, pois não se confinava ao uso que o espectador fazia da obra dentro de espaços internos, institucionais, como museus e galerias, mas era lançado à cidade, dispersando-se simultaneamente em vários pontos, e atingindo espectadores a esmo; a população transformada, ao mesmo tempo, em autor/manipulador e platéia. $\mathrm{O}$ fato de a quase totalidade das ações/situações de Artur Barrio ter se desenvolvido nas ruas, em terrenos baldios, garagens ou áreas abandonadas, fez com que o trabalho cumprisse de maneira exemplar a sua convicção anti-institucional e dissidente, tornando a obra não recuperável e efêmera, além de alargar o domínio público das interferências". CANONGIA, Lígia. Barrio Dinamite IN: CANONGIA, Lígia. Artur Barrio. Rio de Janeiro: Modo, 2002, p. 203.
} 
dos Tabajaras, Copacabana, Leblon, Ipanema e o MAM, [o desgaste físico] me abriu uma percepção fantástica, pois com todo esse caminhar a percepção se aguçou incrivelmente. $\mathrm{O}$ corpo aí já estava mais condicionado à mente, trabalhando mesmo, o corpo era quase uma máquina ${ }^{15}$.

Ações mais comuns no campo das artes plásticas - também são exemplares a distribuição de azulejos de papel feita pelo Poro ${ }^{16}$, de Belo Horizonte, no intuito de permitir às pessoas "comuns" construírem sua própria forma de intervir no espaço urbano ou doméstico, e a disseminação de projetos de intervenção urbana via internet para ser realizados por outras pessoas ou coletivos, como aquelas propostas por meio do PIA, Programa de Interferência Ambiental ${ }^{17}$ do qual faz parte o próprio Poro - esses procedimentos, nos quais o compromisso de produzir a obra é dividido com a coletividade, com o cidadão ${ }^{18}$, têm contaminado o campo das artes cênicas, se manifestando na idéia de desconstrução não só do conceito de representação e de obra de arte - como produção autoral e acabada, pronta para ser entregue à fruição do espectador - mas também, por conseqüência, da noção de espetacularização e de teatralidade. Essa idéia está presente na investigação artística de uma boa parte dos coletivos contemporâneos de artes cênicas, para a qual parece ser ambição criar, a partir da vivência concreta do ato artístico, "pensamento e zonas de interrupção no cotidiano da cidade e na percepção do cidadão”, como explicita o Obscena em seu programa $^{19}$.

\footnotetext{
${ }^{15}$ BARRIO, Artur. 4 DIAS 4 NOITES IN: CANONGIA, op. cit., p. 156.

${ }^{16}$ Poro: intervenções urbanas e ações efêmeras: informação disponível em: www.poro.redezero.org (acesso no dia 06/02/2011).

${ }^{17}$ O PIA é uma "plataforma de artistas que agrega integrantes de diferentes coletivos do Brasil em propostas de ação" e que pode ser "considerado um coletivo temporário, que se forma em situações específicas a partir da eleição de um ponto de encontro, em determinada cidade do país". Informação disponível em: www.piabrasil.wordpress.com (acesso no dia 06/02/2011).

${ }^{18}$ BARRIO, Artur. Lama/Carne Esgoto IN: CANONGIA, op. cit., p. 146: "Portanto, esses trabalhos, no momento em que são colocados em praças, ruas, etc., automaticamente tornam-se independentes, sendo que o autor inicial (EU) nada mais tem a fazer no caso, passando esse compromisso para os futuros manipuladores/autores do trabalho, isto é:... os pedestres, etc.".

${ }^{19}$ Conforme www.obscenica.ning.com (acesso no dia 06/02/2011).
} 


\subsection{Poéticas obscênicas}

O Obscena, agrupamento independente de pesquisa cênica coordenado por mim e pela atriz Lissandra Guimarães, investiga, desde março de 2007, experimentos cênicos e performáticos que têm como referência as relações entre corpo, poder e espaço urbano ${ }^{20}$ e que buscam revisitar e reterritorizar questões referentes às noções de público e privado e às relações entre o acontecimento cênico e o espectador, por meio da pesquisa teórica e prática sobre a ocupação do espaço urbano, o corpoinstalação e a ação não representacional. Além disso, é eixo norteador do trabalho desenvolvido pelo agrupamento, o work in process e a criação artística em rede de colaboração, ou seja, no Obscena, as experimentações se retroalimentam por meio do diálogo constante entre os artistas pesquisadores envolvidos e destes com o público e outros artistas e coletivos teatrais, além de grupos e movimentos sociais aos quais nos vinculamos tematicamente, como é o caso da Marcha Mundial das Mulheres.

No início de 2007, quando um grupo de pesquisadores, egressos do Curso de Artes Cênicas da UFOP ${ }^{21}$, procurou a Maldita - companhia teatral integrada por mim e por Lissandra - havia o interesse, por parte deles, de acompanhar, como observadores, o processo de criação no qual a companhia estava mergulhada. Por mais que houvesse o desejo, por parte da Maldita, de inserir o espectador no processo de criação - e eles, na qualidade de pesquisadores, eram "espectadores especializados" com quem nos interessava dialogar - havia também o entendimento de que essa inserção não deveria ocorrer de modo integral, mesmo porque, sendo o processo balizado nos princípios de

\footnotetext{
${ }^{20}$ Atualmente, o Obscena desenvolve o projeto Corpos Públicos, espaços privados: invasões no corpo da cidade, em parceria com o Centro Cultural da UFMG.

${ }^{21}$ Como professora assistente de Dramaturgia do Curso de Artes Cênicas da UFOP, eu havia orientado projetos de iniciação científica e de extensão que objetivavam a investigação não somente do processo colaborativo, mas, também, de elementos de linguagem investigados por mim, como dramaturga, nos processos de criação desenvolvidos pela Maldita, tais como a dramaturgia rapsódica e as fontes documentais para a criação dramatúrgica. Alguns dos alunos que trabalharam nesses projetos, posteriormente, desenvolveram Trabalhos de Conclusão de Curso nos quais abordavam uma metodologia colaborativa de criação, visando à criação de uma dramaturgia própria, muitas vezes de caráter rapsódico.
} 
uma criação colaborativa, ele já contava, cotidianamente, com a presença - externa à cena - de diretor, dramaturga, cenógrafa, iluminador e músico, além do relator do processo. Resolvemos, então, naquele primeiro momento, propor um grupo de estudos teóricos e práticos, algo que funcionasse como uma espécie de grupo de pesquisa paralelo à Maldita, que pudesse ampliar nossas discussões artísticas e alimentar nossa criação a partir de outras perspectivas sobre a cena. Surgia, assim, o agrupamento independente de pesquisa cênica: Obscena.

Em função do foco de seu interesse ser a pesquisa desenvolvida pela Maldita, o agrupamento começou o estudo por algumas balizas que sustentavam o trabalho de criação em desenvolvimento na companhia: além dos princípios da criação colaborativa, os mecanismos épico-dramáticos e os conceitos de ocupação e instalação. Como discussão teórica de base, havia o desejo, por parte do Obscena, de investigar as possibilidades políticas da cena contemporânea a partir das idéias presentes no epílogo do Teatro Pós-Dramático ${ }^{22}$. Desejo que, sem dúvida alguma, estava vinculado à pesquisa temática da Maldita - que concernia à discussão das estruturas de poder, como as instituições (em Casa das Misericórdias, as instituições manicomiais e, no processo em andamento, as instituições prisionais) - e à sua perspectiva de uma atuação artística de ordem política, mas também ao interesse específico dos pesquisadores do agrupamento de associar essa atuação política à experimentação de ações que permitissem uma inserção mais direta no cotidiano do cidadão, por meio do que chamávamos de “interrupção". Não era nosso desejo produzir materiais cênicos que permitissem dialogar com um possível espectador interessado em assistir/participar de um evento cênico - em outras palavras, criar "um ritual de confirmação para aqueles que já estavam convencidos ${ }^{23}$ - mas intervir, por meio de uma política da percepção (LEHMANN, 2007: 424), no cotidiano das pessoas comuns que, sem nenhuma expectativa ou foco de interesse direcionado para a arte, transitavam pela cidade. Ou seja, desejávamos produzir um acontecimento. Afirma Lehmann:

\footnotetext{
${ }^{22}$ Como o livro ainda não havia sido traduzido no Brasil, trabalhávamos com uma tradução livre que eu havia feito, a partir da tradução francesa: LEHMANN, Hans-Thies. Le théâtre postdramatique. Paris: L'Arche, 2002.

${ }^{23}$ LEHMANN, Hans-Thies. Teatro Pós-Dramático. São Paulo: Cosac \& Naify, 2007, p. 409.
} 
Não é pela tematização direta do político que o teatro se torna político, mas pelo teor implícito de seu modo de representação. [...] O teatro, não como tese, mas como prática, representa exemplarmente uma ligação de elementos heterogêneos que simboliza a utopia de uma "outra vida": trabalho espiritual, artístico e corporal, atividade individual e coletiva são aqui conciliados. Assim, ele pode afirmar uma prática de resistência já pelo fato de dissolver a coisificação de ações e trabalhos em produtos, objetos e informações. Na medida em que o teatro impõe seu caráter de acontecimento, manifesta a alma do produto morto, o trabalho artístico vivo, para o qual tudo permanece imprevisível e está para ser inventado. Portanto, o teatro é virtualmente político segundo a concepção de sua prática (LEHMANN, 2007: 414).

Tendo essas questões como ponto de partida, o Obscena experimentou - em seu primeiro ano de nascimento, estruturação e definições de caminhos - possibilidades cênicas tão férteis que impulsionaram, inclusive, nossa criação dentro da Maldita. A tal ponto que Lissandra e eu, presentes em ambos os processos de pesquisa e não encontrando mais vazão real de nossos anseios artísticos no grupo de origem, resolvemos nos dedicar inteiramente às questões que tinham surgido no grupo de estudos. A fim de dar seguimento à pesquisa iniciada, formulamos o projeto Às margens do feminino: texturas teatrais da beira ${ }^{24}$ e o apresentamos para a Lei Municipal de Incentivo à Cultura. Aprovado no Fundão, o projeto nos deu condições de aprofundar a investigação, agora centrada em um tema recorrente nos experimentos que já vinham sendo desenvolvidos no agrupamento: a mulher.

Interessava-nos, inicialmente, pesquisar os aspectos marginais do feminino, ou seja, aqueles relacionados à mulher que não cabe nos limites impostos pelo padrão vigente na sociedade brasileira: a louca, a puta, a velha e, ampliando a margem e a discussão de gênero, os seres que transitam entre o masculino e o feminino, como o travesti e o transexual. Posteriormente, com o andamento da pesquisa, apontou-se a necessidade de investigar, ainda (para alguns de nós passou a ser mesmo o cerne da pesquisa), a construção do modelo hegemônico da mulher, isto é, o aspecto do

\footnotetext{
${ }^{24}$ Ver Anexo D.
} 
feminino que a sociedade não só aceita, como também fabrica: o feminino "cor-derosa”, a mulher padrão.

Com a aprovação do projeto, em dezembro de 2007, o agrupamento, integrado por sete pesquisadores, rapidamente ampliou seu número para doze. Éramos, inicialmente, Erica Vilhena, Marcelo Rocco e Moacir Prudêncio, diretores formados pelo Curso de Artes Cênicas da UFOP e meus orientandos em seus Trabalhos de Conclusão de Curso; Mariana Bernardes, atriz e bailarina, também formada pela UFOP; Saulo Salomão, ator formado pelo Teatro Universitário da UFMG e recém-saído do Oficinão para atores do Galpão Cine Horto; a atriz Lissandra Guimarães e eu, dramaturga. No início de 2008 agregaram-se ao Obscena William Neimar, dramaturgo e ator, licenciado em Artes Cênicas pela UFOP; Didi Vilela, aluno pesquisador do curso de Artes Cênicas da UFMG; a bailarina Patrícia Sene, pesquisadora de dança criativa, bem como os pesquisadores, formados em Direção Teatral pela UFOP, Clóvis Domingos, que havia sido meu orientando na iniciação científica e era uma importante “aquisição" para o desenvolvimento teórico da pesquisa em curso e Idelino Júnior que, além de ter sido meu orientando em projetos de extensão, havia acompanhado, como relator, o processo de criação da Maldita. Nos primeiros meses de 2008 já tínhamos, por conseqüência, um agrupamento bastante considerável de pessoas com funções artísticas e interesses diversos.

Com a perspectiva de desenvolver uma base comum para o trabalho teórico e prático que fosse assentada sobre os três elementos de linguagem propostos no projeto - a atuação rapsódica, a ocupação dos espaços públicos e urbanos e a ação não representacional, a partir do estudo das ações/situações desenvolvidas pelo artista plástico Artur Barrio - o agrupamento partiu para a abordagem do primeiro aspecto a ser investigado, a atuação rapsódica, por meio da pesquisa de mecanismos épicodramáticos que eu e Lissandra já tínhamos explorado dentro da Maldita e também do estudo da tese de doutorado na qual a pesquisadora Nara Keiserman ${ }^{25}$ aborda a questão. O objetivo era equalizar os conhecimentos teóricos e práticos de todos os integrantes do Obscena, a fim de partirmos para a delimitação dos campos individuais de pesquisa e desenvolvermos os experimentos cênicos a partir dos interesses de cada

\footnotetext{
${ }^{25}$ KEISERMAN, Nara Waldemar. Caminho Pedagógico para a Formação do Ator. Tese (Doutorado em Teatro) - Centro de Letras e Artes da UNIRIO, 2004.
} 
um ou de pequenos núcleos que, eventualmente, se formassem. Mas, para além dos elementos de linguagem a serem investigados, o interesse maior do projeto de pesquisa era a formação de um coletivo criador, de uma rede colaborativa em que as diversas funções artísticas presentes no agrupamento pudessem experimentar a criação. $O$ processo colaborativo - ou, talvez mais especificamente, os princípios e mecanismos que alavancam uma criação colaborativa - como núcleo duro da pesquisa, guiava o modo como pensávamos a evolução das relações e das dinâmicas de trabalho do agrupamento.

Nesse sentido o projeto - embora fosse caracterizado pela experimentação de materiais cênicos a partir tanto da temática como dos elementos de linguagem que sustentavam a investigação - tinha, como questão principal, a produção de dinâmicas que possibilitassem aos pesquisadores relacionar os frutos de suas pesquisas individuais na criação desses experimentos, pois interessava-nos, sobretudo, que o desenvolvimento dos materiais cênicos ocorresse em diálogo: não somente entre os artistas pesquisadores, mas também com o público em geral e com potenciais interlocutores que pudessem acompanhar, desde o início, os processos de criação de cada experimento. Ou seja, era desejo do agrupamento construir uma rede colaborativa que pudesse alimentar, a partir de sua observação e reflexão crítica, as ações do projeto ao longo do período previsto para a sua realização (de fevereiro a dezembro de 2008). Em razão disso, o cronograma das atividades fora desenhado de maneira a prever mostras periódicas - processuais e abertas ao público - dos trabalhos de pesquisa em desenvolvimento, bem como a realização de vários experimentos no espaço urbano, isto é, de intervenções diretas no cotidiano dos cidadãos/transeuntes, em consonância com as ações que, no primeiro ano de existência do Obscena, já havíamos experimentado a partir da idéia de “interrupção". Tal possibilidade era muito instigante para todos nós.

Com minha saída e de Lissandra da Maldita, tínhamos ficado sem espaço para abrigar os encontros do agrupamento, uma vez que nos reuníamos na Gruta, sede da companhia. Em busca de um lugar estratégico, procuramos a Diretoria dos Teatros Municipais, por meio da qual conseguimos fechar uma parceria bastante produtiva com o Teatro Marília, baseada na proposta de ocupação de todo o edifício, desde as vitrines externas até o porão e o pátio que existia nos fundos do teatro. Por ser 
localizado na área central da cidade, o Marília, além de servir como ponto estratégico para os encontros teóricos, abria possibilidades espaciais interessantes, tanto no teatro com no entorno, para a criação de nossos materiais cênicos. Contudo, logo percebemos que, malgrado suas disposições físicas, o edifício "teatro" acabava por forçar uma configuração espetacular, alheia ao que vínhamos desenvolvendo até então. Isso ficou mais evidente após a realização das duas primeiras mostras (abril e junho), quando se tornou patente que os materiais criados pediam o caos da rua, o centro nervoso da cidade, no qual poderiam amadurecer e experimentar sua real potência de “interrupção" e intervenção. Era perceptível que o Teatro Marília não nos cabia inteiramente, pois não atendia à natureza de muitos experimentos para os quais já começava a se desenhar um caminho claro de linguagem.

Como já disse, havíamos iniciado a pesquisa pelo estudo de mecanismos narrativos e de uma atuação rapsódica, trabalho que tinha como base experiências vinculadas a uma cena absolutamente teatral e representacional, ainda que não dramática. Embora atendesse o anseio específico de alguns pesquisadores - que, de certo modo, acalentavam a idéia de construção de um espetáculo e de formação de um grupo de teatro a partir da pesquisa realizada pelo Obscena - isso gerava contradições em relação aos outros dois elementos propostos no projeto, ambos de natureza mais performática, e ao modo de estruturação do agrupamento, pois sua organização alicerçada no desenvolvimento de pesquisas individuais que eram alimentadas por uma rede de colaboração e diálogo - não comportava a criação de cenas que exigissem a participação de todos os pesquisadores. Queríamos as trocas inerentes a essa rede, mas não a criação de uma obra em comum. Para a maioria dos pesquisadores envolvidos havia um interesse evidente na manutenção de uma liberdade de criação que possibilitasse a radicalização da pesquisa e dos experimentos cênicos gerados no atrito entre matérias e pensamentos.

Dessa perspectiva, a atuação rapsódica - bem como o edifício teatro - parecia limitar as possibilidades poéticas dos pesquisadores. Assim, optamos em partir para a abordagem simultânea dos outros dois elementos de linguagem que orientavam o projeto, uma vez que eles estavam absolutamente imbricados: a ocupação dos espaços públicos e urbanos e as ações/situações desenvolvidas por Artur Barrio. Como base 
teórica, tínhamos a dissertação de Merle Ivone Barriga ${ }^{26}$, que havia pesquisado as ações do artista plástico português como um modelo não representacional para o ator contemporâneo. Logo a noção de ação não representacional tornou-se, para nós, uma questão em si, pois suscitava muitas discussões em torno dos conceitos de representação, teatralidade e performatividade ${ }^{27}$, além da idéia de espetacularização da sociedade contemporânea ${ }^{28}$.

Para investigar na prática a questão, nos lançamos em experimentações que tinham como ponto de partida a leitura e discussão da dissertação de Barriga e suas investigações práticas. Buscávamos ações que nos permitisse provocar estranhamentos, mas que não se configurassem, de maneira nítida para o transeunte, como cenas ou como teatro. Para isso, explorávamos, nas ações propostas, determinados elementos deslocados de contexto, como, por exemplo, dançar no metrô uma música que era ouvida somente pelo atuante ou entrar em um shopping estando bem vestida, mas descalça. Como afirma André Carreira ${ }^{29}$, propor ações de intervenção na cidade - para além da possibilidade de criar uma ação política ou de manifestar um compromisso radical de investigação artística - implica na perspectiva de considerar "a cidade como um campo simbólico no qual o teatro se instala, inevitavelmente, como elemento de ruptura com os fluxos do cotidiano". Nesse sentido, intervir na cidade é criar "um gesto que se politiza porque representa uma ocupação objetiva de um espaço definido por um repertório de usos cotidianos, ao qual o teatro não pertence naturalmente" (CARREIRA, 2009: 3).

\footnotetext{
${ }^{26}$ RAMIREZ, Merle Ivone Barriga. As ações de Artur Barrio: um modelo não representacional para o ator contemporâneo. Dissertação (Mestrado em Artes Cênicas), Escola de Comunicações e Artes da USP, 2006.

${ }^{27}$ Em março, o Obscena tinha acompanhado as palestras do ECUM - Encontro Mundial de Artes Cênicas - no qual entramos em contato mais direto com esse conceito, discutido por Josette Féral.

${ }^{28}$ Conforme as teorias do intelectual situacionista Guy Debord, em A sociedade do espetáculo (DEBORD, Guy. La société du spectacle. Paris: Éditions Gérard Lebovici, 1988).

${ }^{29}$ CARREIRA, André. Ambiente, fluxo e dramaturgias da cidade: materiais do Teatro de Invasão IN: O PERCEVEJO on line, periódico do Programa de Pós-Graduação em Artes Cênicas da UNIRIO, vol. 1, fascículo 1, janeiro-junho/2009, p. 3.
} 
Barrio se mostrava especialmente frutífero. Em maio, Clóvis Domingos, instigado pela obra do artista plástico ${ }^{30}$, propôs - como procedimento coletivo, ou seja, para ser realizado por todos os pesquisadores do agrupamento - uma caminhada performática que gerou muitas possibilidades futuras: havia elementos de instalação, a força da ação coletiva e direta, as possibilidades de diálogo e interrupção concreta na relação com o cidadão belorizontino. O procedimento consistia em percorrer, em conjunto e em silêncio, um trajeto indeterminado pela cidade, recolhendo materiais na rua que nos chamasse a atenção. Posteriormente, e sob o comando de Clóvis - que determinava o lugar para cada um de nós - deveríamos montar uma instalação com os objetos recolhidos e, em seguida, colocar nosso corpo dentro dela, sem intenção de construir "histórias" ou representar ações. Tão fértil se mostrou a caminhada que ela se tornou uma prática recorrente nos trabalhos do agrupamento, tendo sido, inclusive, proposta como um procedimento a ser experimentado junto ao público durante a mostra processual de junho.

Para a mostra, a instrução guia era privilegiar a investigação e o aprofundamento das ações não representacionais. Foi sugerida a seguinte divisão para os procedimentos, a fim de permitir o registro e o acompanhamento integral da mostra, além da participação efetiva de alguns de nós, como atuantes, na proposta dos outros pesquisadores: no primeiro dia, seriam realizados os experimentos de Idelino Júnior, Lissandra Guimarães, Didi Vilela e William Neimar, além do meu. No sábado, iríamos experimentar as propostas de Marcelo Rocco, Patrícia Sene, Mariana Bernardes, Moacir Prudêncio, Saulo Salomão e, novamente, a realização de um experimento meu. O domingo seria reservado para a caminhada performática, orientada por Clóvis Domingos.

O aprofundamento da pesquisa em torno das ações não representacionais refletiu-se, claramente, na alteração de rumo dos experimentos desenvolvidos por uma boa parte dos pesquisadores do agrupamento. Essa alteração se refletia, de modo

\footnotetext{
30 "Como podemos criar mecanismos para chegar ao espectador e convidá-lo para uma AÇ̃̃O? Um ponto que me fascina em Barrio é a "dessacralização" do artista e da obra de arte. Como diminuir a distância entre aquele que propõe e aquele que é provocado? Barrio abandona seus objetos, atua como um contra-regra, e deixa que o transeunte estabeleça uma relação totalmente livre com a obra, até sem saber que "aquilo" foi elaborado por um artista. Vejo aí uma grande transgressão [...]. Será que é abrir mão de uma autoria e deixá-la livre para a criação e apropriação do Outro?”. Relato de Clóvis Domingos, postado no dia 10/06/2008, no Blog do Obscena: www.obscenica.blogspot.com.
} 
marcante, no interesse que começava a se estabelecer pela ocupação dos espaços urbanos, interesse evidenciado em suas proposições de ações e no formato definido para a terceira mostra de pesquisa do Obscena, realizada em agosto: denominada de Cartografias obscênicas, a mostra propunha a experimentação de ações simultâneas na rua.

Terceira mostra do OBSCENA. [...] Trabalhos ganham o corpo da cidade e se alternam. Pude ver alguns, ouvir relatos de impressões de outros ou então imaginar como alguns aconteceram. Simultaneidade e acontecimento. Parece-me que as pesquisas individuais estão mais definidas e ganham corpo e espírito.

Na quinta acompanhei o procedimento de Didi: uma persona atormentada entre o pólo feminino e masculino caminha pelo centro da cidade. Travesti? Mulher? Homossexual? Drogado? Decadente? O fato é que [ele] altera o cotidiano das ruas e lugares por onde passa. [A persona] caminha como numa procissão e encontra gente de todo tipo: pessoas chocadas com aquela aberração, trabalhadores assustados e excitados com aquele corpo tão ambíguo, mendigos marginalizados e solidários àquela moradora das ruas e das lixeiras, corpos que se desviam quando aquela figura aparece. [...] Incômodo e estranhamento num mundo tão asséptico e organizado ${ }^{31}$.

Como reflexo da mostra e da avaliação de seus resultados, optamos, em setembro, por uma nova dinâmica de trabalho para os meses finais da pesquisa desenvolvida dentro do projeto. No lugar de abrirmos o trabalho somente nas mostras que ocorriam a cada dois meses - nas quais, por mais que tivéssemos o cuidado de explicitar o aspecto processual dos experimentos cênicos, estes acabavam por adquirir um caráter espetacular, de "apresentação de cenas", gerando, com isso, uma expectativa em relação à sua forma e uma visão distorcida de seu aspecto "inacabado" passamos a realizar as intervenções a cada segunda-feira, dia que era destinado ao encontro de todos os pesquisadores do agrupamento e que servia, anteriormente, para as discussões teóricas e para a realização das práticas coletivas. O intuito era que todos

${ }^{31}$ Relato de Clóvis Domingos, postado no dia 31/08/2008, no blog do Obscena: www.obscenica.blogspot.com. 
pudessem acompanhar o desenvolvimento das experimentações pesquisadas individualmente e contribuir, a partir de suas avaliações e de apontamentos para o trabalho, mais diretamente para o seu amadurecimento. O teatro Marília (de onde, muitas vezes, saíamos para a rua) serviria como ponto de encontro para o fechamento do dia de trabalho, marcado pela discussão dos experimentos realizados a cada segunda-feira. Estes, mais do que ações já definidas e roteirizadas, eram - para usar a terminologia de Barrio - trabalhos processos que possibilitavam, a nós, o estudo de seus efeitos e a definição de determinados aspectos que os fizesse desembocar em materiais mais concretos, em intervenções por meio das quais pudéssemos travar diálogos efetivos com a cidade e o cidadão. Para André Carreira, as experiências de intervenção no ambiente urbano "são falas que formulam hipóteses sobre a cidade, e [...] tratam de permanecer como registro na memória dos cidadãos". Segundo ele, o diálogo que ocorre entre o acontecimento e o cidadão "representa a abertura, em primeiro lugar, de um espaço imaginário potencial: um novo território da cidade, um convite para o estabelecimento de novos vetores do ambiente" (CARREIRA, 2009:5).

Com essa mudança no rumo da pesquisa, as ações começaram a adquirir uma configuração mais precisa: As pombas-gira caminhantes, de Idelino Júnior; $O$ mercado da buceta, de Erica Vilhena; As escutas perfumadas, de Clóvis Domingos, A louca de rua, de Didi Vilela, As Mulheres Mortas, produzidas na relação entre minhas escritas e o corpo cênico de Lissandra. E, como fruto do diálogo entre Mulheres Mortas e Mercado da Buceta (e da integração da atriz Joyce Malta, que entrara para o agrupamento em setembro), a intervenção urbana Baby Dolls, uma exposição de bonecas.

Na mostra final do trabalho de pesquisa desenvolvido pelo projeto Às margens do feminino, o Obscena optou pela realização de um fórum de compartilhamento, que contou com a exibição dos registros audiovisuais das ações desenvolvidas no âmbito do projeto e com a apresentação, por parte de cada integrante do agrupamento, de suas pesquisas individuais, por meio da explicitação de seus objetivos, percurso de criação e resultados alcançados. A partir desse balanço geral, foi possível lançar pontes para o amadurecimento futuro dos embriões gerados no projeto. O fórum, realizado de 10 a 12 de novembro de 2008, foi bastante produtivo, pois, a partir dele, geramos, ainda, materiais teóricos que serviram de semente, tanto para o desenvolvimento das 
pesquisas acadêmicas, realizadas por alguns integrantes do Obscena nos anos seguintes $^{32}$, como para a projeção de ações futuras do agrupamento que vinculassem, à sua produção artística, uma atuação marcadamente política e social, como foi o caso das ações produzidas junto à Marcha Mundial das Mulheres e do projeto Diálogos Obscênicos, realizado, em 2009, junto a adolescentes do sexo feminino em privação de liberdade.

\subsection{Performando a dramaturgia ou Uma escrita performada}

Em 2008, os elementos temáticos e poéticos investigados pelo Obscena durante o projeto de pesquisa Às margens do feminino geraram, além das mostras processuais e fóruns de discussão realizados ao longo do ano, experimentos cênicos e performativos que visavam, sobretudo, engajar o cidadão em uma ação interventiva. Entre eles, Baby Dolls, uma exposição de bonecas. Fruto do diálogo entre minha investigação dramatúrgica e as pesquisas atorais de Lissandra Guimarães, Erica Vilhena e Joyce Malta, a intervenção discute a "fabricação" do modelo de feminino presente na sociedade contemporânea e a conseqüente destruição da mulher como sujeito, por meio da violência que contra ela - vista como objeto e propriedade masculina - é perpetrada.

Três tapetes. Três nichos de exposição. Três bonecas, monumentos animados das mulheres objetos, convidam os transeuntes a brincar. Mulheres princesas, mulheres noivas, mulheres dóceis. Mulheres mudas. Mas não se engane. Logo, essas bonecas serão mulheres mortas, marcadas a giz no chão.

${ }^{32}$ Tanto a pesquisa que desenvolvo na presente tese, como as dissertações de mestrado de Clóvis Domingos - A Cena Invertida e a Cena Expandida: projetos de aprendizagem e formação colaborativas para o trabalho do ator - e de Marcelo Rocco - A aproximação entre a cena e o espectador transeunte na sociedade espetacularizada: “Às margens do feminino" agrupamento Obscena - têm raízes na investigação realizada pelo projeto de pesquisa, em 2008. 
A intervenção vem sendo realizada, desde outubro de 2008, nas ruas e praças de Belo Horizonte, tendo também se apresentado, em 2009, no Festival de Inverno de Ouro Preto e Mariana, no Festival Internacional de Teatro de São José do Rio Preto, na MIP2 - Manifestação Internacional da Performance - e no XII Festival Recife do Teatro Nacional, no qual nossa ação foi ampliada: além das cinco intervenções que fizemos nas periferias da cidade, foi realizada uma intervenção integrada por outras "bonecas", construídas a partir dos elementos propostos no workshop Como se fabrica uma mulher? que ministramos exclusivamente para mulheres artistas atuantes em Recife.

À luz das questões desenvolvidas por Josette Féral ${ }^{33}$ acerca das noções de performance e performatividade, pretendo, agora, discutir os processos de construção do que denomino como escrita performada - a escrita produzida no fluxo da ação performativa e em relação com o espaço da cidade - desenvolvida por mim no âmbito dos experimentos investigados, em 2008 e 2009, pelo Obscena e que abrange, principalmente, o percurso de criação e as intervenções realizadas por Baby Dolls, uma exposição de bonecas nas cidades mencionadas acima. Além disso, abrange também as intervenções produzidas, em 2008, no âmbito do experimento denominado de Mulheres Mortas e que serviram como ponto de partida para Baby Dolls. Meu interesse é abordar a criação de uma escritura processual cujo suporte material não é mais a folha de papel, mas o espaço da cidade e o corpo.

Contudo, quando comecei o trabalho de pesquisa, em fevereiro de 20o8, não tinha clareza, ainda, em relação nem à denominação empregada por mim nem às possibilidades de criação dramatúrgica que ela denota. Como fruto de uma investigação processual, essa criação teve seus caminhos definidos à medida que eles eram trilhados, o que é evidenciado pelas várias terminologias que empreguei para tentar dar conta das textualidades que eram por mim produzidas, tanto durante o

33 FÉRAL, Josette. Por uma poética da performatividade: o teatro performativo IN: Sala Preta, revista do Programa de Pós-Graduação em Artes Cênicas. São Paulo: ECA/USP, n. 8, 2008, p. 197-210 (tradução de Lígia Borges).

Performance et théâtralité: le sujet démystifié. Arquivo cedido pela autora : texto publicado originalmente em inglês, IN: Modern Drama, vol. 25, 1982, pp. 170-181.

La performance ou le refus du théâtre IN: Protée, vol. 17, 1989, pp. 6o-66.

Que reste-t-il de la performance? Autopsie d'une fonction; la naissance d'un genre. Arquivo cedido pela autora : texto publicado originalmente em inglês, IN: Discourse, Journal for theoretical studies in media and culture Performance Issue(s): Happenings, Body, Spectacle, Virtual Reality, 1992, pp. 140161. 
desenvolvimento do projeto de pesquisa como, posteriormente, no processo de criação das intervenções já mencionadas: dramaturgia do momentum, escritura cênicodramatúrgica conjugada e, por fim - inspirada nas Escutas Perfumadas desenvolvidas pelo pesquisador Clóvis Domingos - o termo definitivo: escrita performada.

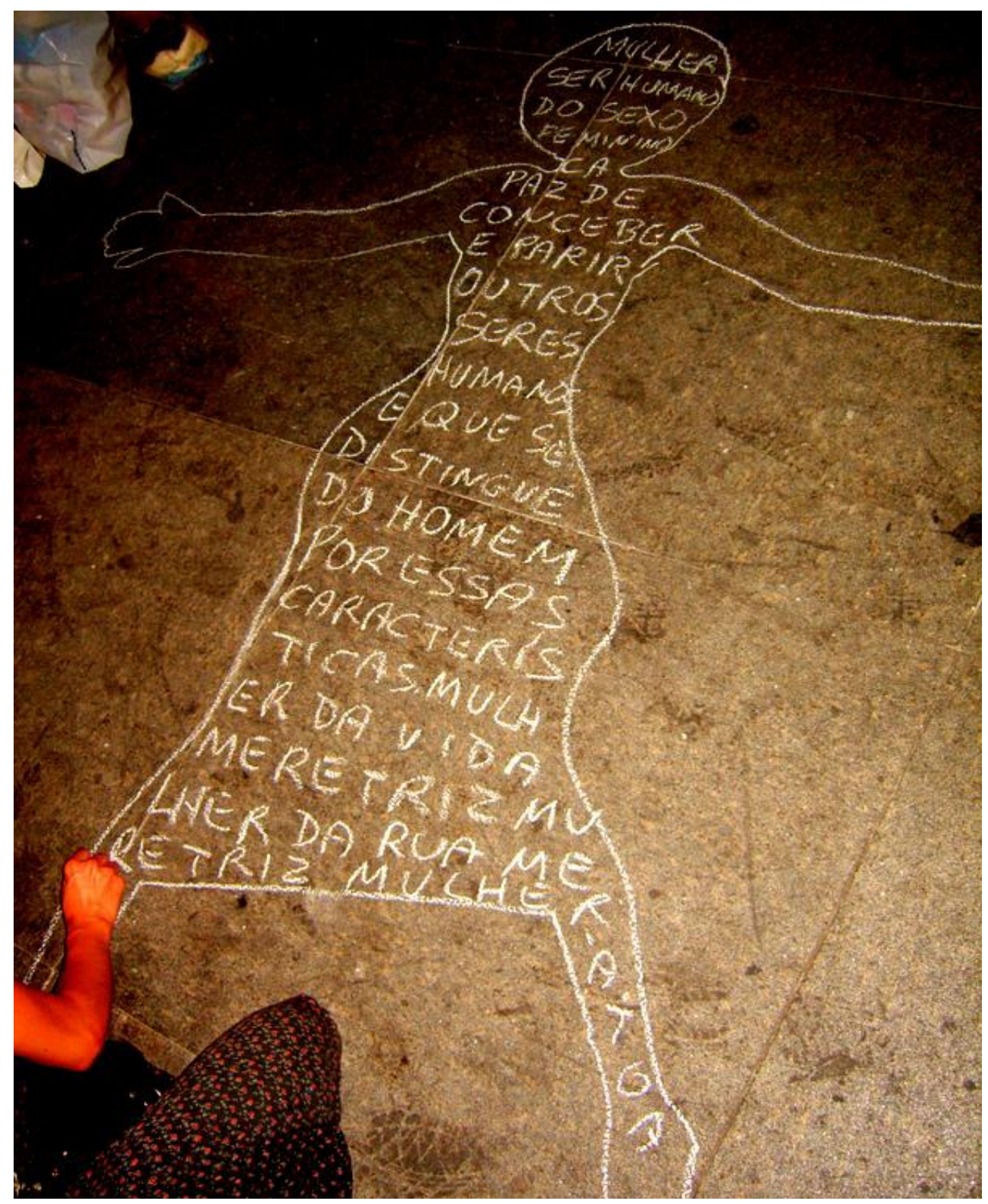

FIG. o8. Nina Caetano: Mulheres Mortas. Foto de João Alberto Azevedo

Ao empregar esse termo, busco traçar uma distinção em relação tanto à noção de escrita performática presente nos estudos da performance quanto àquela presente nos estudos literários. No campo dos estudos da performance, o termo escrita performática refere-se aos ensaios/críticas/registros, em geral autobiográficos, de 
performances realizadas, os quais funcionam como uma espécie de arquivo, ainda que busquem trazer à tona novamente "a força afetiva do evento performático ${ }^{34 "}$ ao ultrapassar, em certa medida, o registro lingüístico. Para Graciela Ravetti ${ }^{35}$, o "transgênero performático privilegia a voz, quer mostrar o movimento, registrar a ação e produzir efeitos de sensações”. Ao contrário do acontecimento performático, no entanto, a escrita performática pressupõe a existência do suporte de papel e o domínio do código alfabético para sua construção. Nesse sentido, muitas vezes, ela pode vir a servir, segundo Diana Taylor ${ }^{36}$, "como uma estratégia de repúdio e de clausura das práticas corporificadas que proclama descrever".

Já para os estudos literários, a escrita performática está estreitamente vinculada à noção de escritura (Barthes) e ao conceito de texto como produtividade e construção dialógica (Bakhtin, Kristeva). Como já visto ${ }^{37}$, para Barthes a noção de escritura busca ultrapassar - assim como o transgênero performático - os limites ao que a literatura ou mais especificamente o texto literário, pensado dentro de certa tradição - está submetida.

\footnotetext{
É bem possível que a literatura, apesar de sua sobrevivência na cultura de massa, seja pouco a pouco privada, pelo próprio trabalho dos escritores, de seu status tradicional de arte realista ou expressiva; e realize sua própria destruição para renascer na forma de uma escritura que já não estará exclusivamente ligada ao impresso, mas será constituída por todo trabalho e toda prática de inscrição (BARTHES, 2004: 64).
}

Nesse sentido, pode-se dizer que a escrita performática, para a teoria da literatura, nasce de uma percepção clara das possibilidades de construção de um "texto" diferente daquele produzido pelo escritor, de um texto mental que se projetaria da mente do leitor, ou, em outras palavras, da existência de uma "performance leitora ou narrativas desmaterializadas - duas expressões para nomear o resultado do embate

\footnotetext{
${ }^{34}$ PHELAN, Peggy. Performative writing IN: Mourning Sex. 1997, pp. 11-12. Tradução minha, do original em inglês: "To enact the affective force of the performance event again".

35 RAVETTI, Graciela. Performances escritas: o diáfano e o opaco da experiência IN: HILDEBRANDO, Antônio et alii (org.). O corpo em performance: imagem, texto, palavra. Belo Horizonte, NELAP/FALE/UFMG, 2003, p. 41.

${ }^{36}$ TAYLOR, Diana. Encenando a memória social: Yuyachkani IN: RAVETTI, G. \& ARBEX, M. (org.). Performance, exílio, fronteiras: errâncias territoriais e textuais. Belo Horizonte: FALE/UFMG, 2002, p. 20.

${ }^{37}$ No capítulo 1, da presente tese.
} 
performático entre texto e leitor - suscitadas pela existência de textos literários abertos e dialógicos ${ }^{38 ”}$. A escrita performática seria, então, uma espécie de encenação "do si mesmo da palavra para um outro", na qual a palavra, ou seja, o verbo, "se vê movido por um desejo de se deslocar, provisoriamente, da página impressa e de se inscrever (...a partir de uma escrita outra, realizada pelo leitor) na efemeridade performática da tela da consciência, da imaginação do receptor" (LEAL, 2008:01). Nesse caso, não só a literatura é performática - e só o é quando provoca o leitor à produção de outros textos para além dela, isto é, quando é um "texto de fruição", nos dizeres de Barthes - como também é performático aquilo que ocorre entre o texto e o leitor.

Segundo Josette Féral $^{39}$, a performatividade não é uma “propriedade” dos objetos, da ação ou do texto, mas uma dinâmica de relação que investe esses objetos, essa ação ou esse texto. Na esteira de Schechner, ela afirma que considerar uma obra ou um objeto como performance significa "investigar o que o objeto faz, como ele interage com outros objetos ou seres e como ele se relaciona com outros objetos e seres. Performance existe somente como ação, interações e relações ${ }^{40 ”}$. Desse modo, para Féral ${ }^{41}$, o que vai definir a noção de performatividade - uma vez que ela não é uma qualidade intrínseca ao objeto performativo - é o seu caráter de acontecimento, em primeiro lugar. Como decorrência desse traço, a performatividade evocaria a presença concreta do performer, o que parece implicar uma noção de risco, tanto para o performer quanto para o espectador. Nesse sentido, é possível afirmar que ela se traduz, fundamentalmente, como uma experiência, pois o espectador "longe de buscar um sentido para a imagem, deixa-se levar por esta performatividade em ação. Ele

\footnotetext{
${ }^{38}$ LEAL, Juliana Helena Gomes. Escrita performática latino-americana contemporânea IN: Anais do Congresso Internacional da ABRALIC: Tessituras, interações, convergências. São Paulo: USP, 13 a 17 de julho de 2008, p. 6

${ }^{39}$ Conforme anotações realizadas durante a disciplina Teoria e Prática do Teatro, ministrada por Josette Féral na Escola de Comunicações e Artes da USP, em agosto de 2009.

${ }^{40}$ SCHECHNER, Richard. What is performance? IN: Performance Studies: an Introduction. New York \& London: Routledge, 2006, p. 30. Tradução minha do original em inglês: "To treat any object, work, or product "as" performance - a painting, a novel, a shoe, or anything at all - means to investigate what the object does, how it interacts with other objects or beings, and how it relates to other objects or beings. Performance exist only as actions, interactions, and relationships".

${ }^{41}$ FÉRAL, Josette. Por uma poética da performatividade: o teatro performativo IN: Sala Preta, revista do Programa de Pós-Graduação em Artes Cênicas. São Paulo: ECA/USP, n. 8, 20o8, pp. 197-210.
} 
performa” (FÉRAL, 2008: 203). Se, no reino da teatralidade ${ }^{42}$, a obra é pensada como resultado, no reino da performatividade, ela é processo.

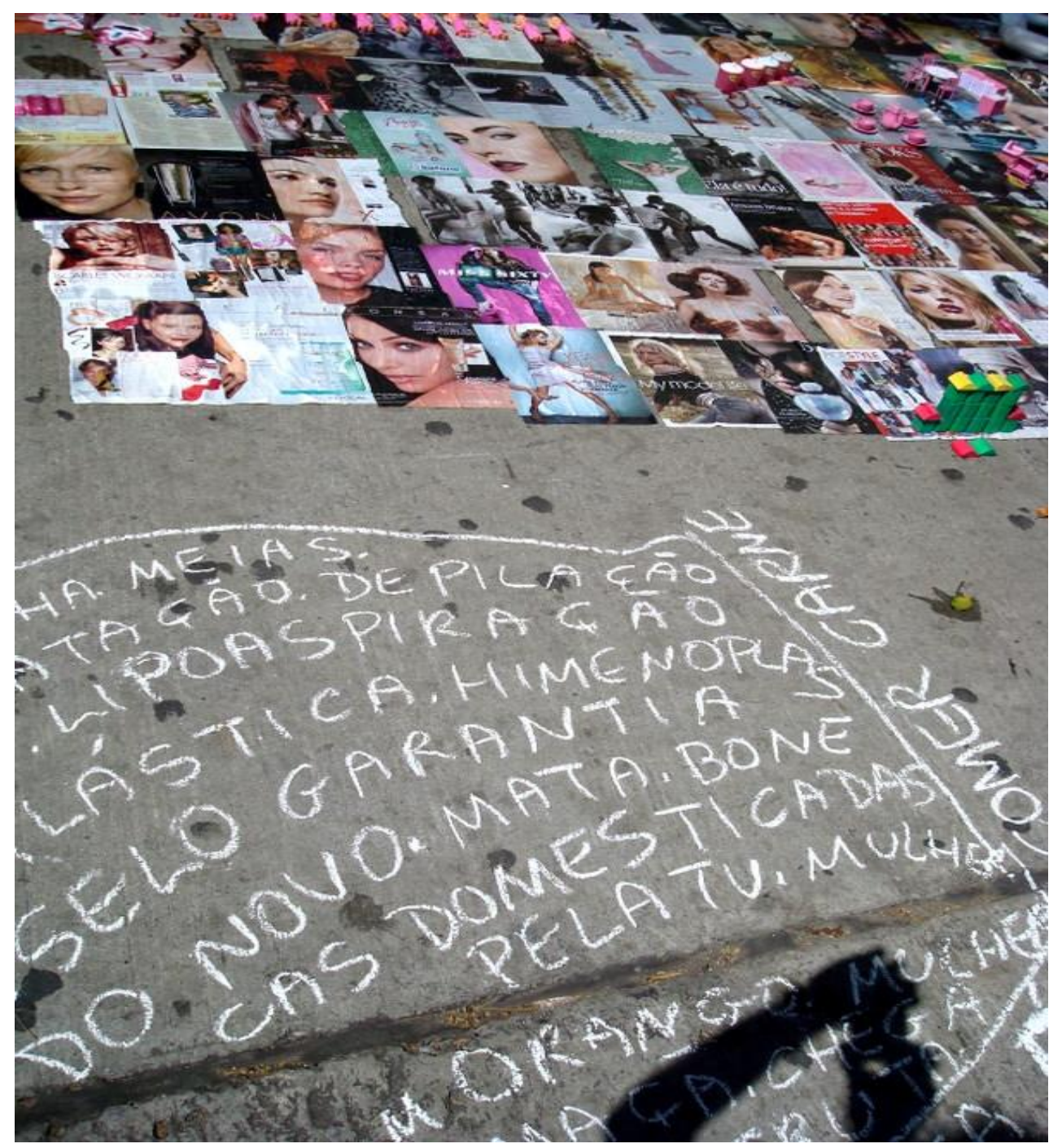

FIG. o9. Baby Dolls, uma exposição de bonecas. Foto de João Alberto Azevedo

Como disse, quando o agrupamento deu início ao processo de pesquisa, ainda não havia clareza, para mim, em relação ao modo como eu poderia desenvolver uma dramaturgia, a partir dos elementos poéticos que eram foco do meu interesse, dentro de um agrupamento e de um projeto que privilegiava, de certo modo, a instância atoral, perspectiva evidenciada pelo desenvolvimento de uma prática corporal

\footnotetext{
${ }^{42}$ Embora as duas noções não sejam contraditórias, e sim, como afirma Féral, complementares: "dentro de toda teatralidade, há performatividade. E, dentro de toda performatividade, há teatralidade" (Féral, conforme anotações realizadas durante a disciplina).
} 
constante dentro do Obscena. Naquele momento, estavam claros para mim somente os aspectos temáticos do que desejava investigar. Remeto ao relato do dia 25 daquele mês:

Eu, Nina, me interesso por pesquisar o documento, a intervenção do real, os labirintos temporais, a memória. A construção da mulher. Uma anatomia, para lembrar Moacir, construída com objetos normalmente ligados ao universo da mulher. Interessa a mulher que transborda seus limites, que escapa às fôrmas, me interessa a loucura. O que cabe e o que não cabe ${ }^{43}$.

Nesse sentido, a principal questão dizia respeito às possibilidades de tecer uma dramaturgia a partir do corpo e na relação com os materiais cênicos dos outros pesquisadores, uma vez que não intentávamos a criação de um espetáculo, mas resultantes cênicas decorrentes de investigações individuais, ainda que produzidas em uma rede colaborativa. No ano anterior, como eu estava em pleno processo de criação da dramaturgia do novo espetáculo da Maldita, acabava por direcionar as pesquisas que realizava dentro do Obscena - como grupo de estudos vinculado à companhia para o desenvolvimento dessa criação. As questões levantadas acima eram, então, incipientes, uma vez que, para mim, havia espaço garantido, no processo da Maldita, para o amadurecimento de minhas investigações dramatúrgicas. Desse modo, utilizar o meu corpo na ação era, muitas vezes, um meio de concretizar propostas de dramaturgia que seriam, posteriormente, desenvolvidas pelos atores.

Contudo, na Maldita a tensão em nível pessoal provocada pelas separações ocorridas entre os quatro membros fundadores da companhia ${ }^{44}$, emperrara o processo de criação que já se desenrolava há quase dois anos. Além disso, tínhamos, tanto eu como Lissandra, muitas questões relativas ao nosso espaço como mulheres, não só na Maldita como também no mundo. Nesse sentido, o processo criativo há muito já não nos satisfazia, pois não permitia a colocação efetiva de nossas questões, que eram consideradas, pelos outros integrantes, como muito "particulares". Tal contexto nos levou a sair da companhia, em novembro de 2007, e nos dedicar inteiramente às

\footnotetext{
${ }^{43}$ Relato postado no blog do Obscena: www.obscenica.blogspot.com.

${ }^{44} \mathrm{Eu}$ e Lissandra havíamos decidido, quase simultaneamente, nos separar de nossos maridos, respectivamente diretor e ator da montagem em andamento, e esta situação pessoal acabou por comprometer o diálogo criativo entre o diretor e a dramaturga e entre os dois atores em cena.
} 
questões férteis que tinham surgido no grupo de estudos, bem como ao seu tema central: a mulher.

Segunda-feira, dia 03 de março de 2008. O que é ser mulher?

Fortaleza fragilidade mãe mulher companheira doçura esteio $=$ sustentação da família Geradora de vida. Amor. Carinho. Benção. Ser divino. Luz do Mundo.

Ser mulher é ser como sempre uma escrava de quase tudo. Sou feliz como mãe. Como mulher não.

Ser mulher é muito importante porque ela é a Rainha do Lar.

Ser mulher tem que ter responsabilidade com a família, com o esposo. Ser mulher vem da responsabilidade desde o dia da gravidez porque todos dependem da mulher.

A mulher cuida das crianças, dos filhos, da casa. É dar respeito para ser respeitada.

Ser mulher pra mim é saber se calar mesmo querendo extravasar. É ser forte, mesmo nos momentos de dor.

Ser mulher é ser dona de casa, ser mãe de família, ser paciente, ser cuidadosa, ser conselheira, ser trabalhadeira, ser cuidadosa, ser bonita ${ }^{45}$.

Em março de 2008, as questões que eram incipientes no trabalho desenvolvido no ano anterior, começaram a tomar (o meu) corpo, a partir das experimentações de procedimentos atorais que nortearam a primeira fase dos trabalhos. A distância que os procedimentos tinham em relação a uma criação dramatúrgica produzia a necessidade de se buscar caminhos que me conduzissem a ela. Era o início de uma investigação das possibilidades do corpo como suporte para a escrita, questão que se acirrou a partir da primeira mostra processual de pesquisa, prevista pelo projeto e realizada em abril.

Nessa primeira mostra, os pesquisadores do agrupamento tinham proposto experimentos individuais que contavam, muitas vezes, com a participação dos outros artistas para sua realização. A necessidade de colaborar, como atuante, na proposta do outro me levou a questionar o modo de produção textual e o estatuto da dramaturgia

${ }^{45}$ Frases escritas por mulheres durante oficina ministrada por Hosana Passos, militante da Marcha Mundial das Mulheres, movimento feminista e anti-capitalista de ordem mundial. Os escritos realizados a partir da pergunta: O que é ser mulher? - foram mostrados ao agrupamento por Hosana, durante nossos primeiro contato, realizado em 03 de março de 2008 e posteriormente transcritos em meu relato pessoal, postado no blog do Obscena: www.obscenica.blogspot.com. 
nessa produção. Na condição de dramaturga, a questão que norteava minha investigação era, principalmente, as possibilidades de criação de uma textura cênica por meio da utilização do meu corpo - que pudesse funcionar como estrutura organizadora dos sentidos produzidos. Para explicitar a questão, cito a proposta de Marcelo Rocco, Vitrine de corpos prostituídos, realizada no primeiro dia da mostra, sábado 12, à meia-noite.

Marcelo havia solicitado a todos os pesquisadores, tanto mulheres como homens, que atuassem exibindo seus corpos, colocados em exposição na vitrine do Teatro Marília. As nossas ações seriam guiadas por indicações dele e tínhamos - como elemento motor - diversos objetos que Marcelo havia espalhado pela vitrine. Uma vez que minha pesquisa não tinha caráter atoral, nem eu queria "representar" papéis, aceitei exibir meu corpo com uma ressalva. Eu não iria seguir os seus comandos muitas vezes concentrados em nos impor a representação de corpos prostituídos, pois eram ordens do tipo: "mostra como você é gostosa” ou "deixa ele doido, vai” - mas exercitar, de dentro da vitrine, as possibilidades de diálogo com o público pela escrita, que eu imprimiria na vitrine e nos corpos dos outros atuantes. Concentrei-me em perceber a reação do público, composto, em sua maioria, por homens que transitavam pela Avenida Alfredo Balena: seus olhares ávidos variavam entre o desejo e a repreensão de nosso ato. Em conseqüência, os escritos também variavam: daquilo que eu percebia como "pensamentos” deste público (filé, gostosa, puta) a um discurso mais crítico (Mulheres vendem cerveja, planos de saúde, carros. Mulheres vendem. Mulheres vendem-se. Vende-se Carne).

Nessa mostra, além da escrita experimentada na Vitrine de corpos prostituídos, proposta por Marcelo Rocco, também experimentei - em fluxo relacional com os materiais cênicos desenvolvidos por Lissandra em torno da investigação de um corpoinstalação, construído a partir de objetos do universo feminino (utensílios domésticos, embalagens de produtos, materiais de limpeza e eletrodomésticos) - a realização de uma espécie de catálogo de exposição, um inventário de tarefas femininas, impresso na vitrine e criado no diálogo com os materiais atorais. A proposição logo foi estendida às outras mulheres do agrupamento: 
Dona de uma flexibilidade invejável no trato caseiro, Vaca Maravilha é o sonho de consumo de todo homem, seja ele clássico ou contemporâneo. Na terça-feira, dia 15 de Abril de 2008, algumas pessoas, transeuntes da Avenida Alfredo Balena, no centro da capital mineira, tiveram a oportunidade de testemunhar a eficiência da super heroína que estava exposta em vitrine fazendo uma demonstração de suas qualidades. Acompanhada de outras "colegas de trabalho", dentre elas a Mulher Mil e Uma Utilidades, a Costurinha e a Mulher Ajax, a Fêmea Vaca Maravilha arrancou suspiros da platéia enquanto limpava, esfregava, desinfetava o espaço corroído de mofo e tédio. (...) Outra colega, notadamente a dona da voz daquelas mulheres in vitro, uma mulher cuja ação determinava os sentidos da imagem, trazia consigo uma caneta e com ela preenchia o vidro com palavras, frases, algumas vezes utilizando um léxico bastante comum aos homens. Ela estava do lado de fora, com a platéia, ocupando uma posição naturalmente não-representativa. Era uma artista plástica das palavras e o seu quadro estava vivo ${ }^{46}$.

Esse experimento, estreitamente vinculado aos meus objetivos e à minha temática, tornou mais evidente, para mim, de que modo poderia ser articulada a construção do que, naquele ponto da pesquisa, eu denominava como dramaturgia do momentum, ou seja, a produção de uma escrita no fluxo da ação, a partir do meu olhar de autora-espectadora. O aspecto “distanciado" em relação tanto ao trabalho desenvolvido pelas atuantes como ao meu próprio modo de atuação - percebida por mim não como ação performativa, mas como uma criação dramatúrgica que, no lugar de ser produzida no gabinete, era realizada no calor do momento - caracterizava a minha produção escrita. Hodiernamente, ao utilizar o termo escrita performada para nomear essa produção, busco explicitar, de modo diverso da primeira terminologia empregada, justamente a implicação dessa escrita na ação performativa, por meio de seus fluxos relacionais.

Após a primeira mostra processual, realizada em abril, apontou-se a necessidade de aprofundamento de aspectos referentes a uma noção na qual apenas tínhamos tocado e que, em larga medida, ainda era confusa para a maioria de nós: a noção de ação não representacional. Nesse momento da pesquisa, ainda eram recorrentes

${ }^{46}$ Relato do pesquisador Moacir Prudêncio, postado no dia 21/04/2008, no blog do Obscena: www.obscenica.blogspot.com. 
questões relativas à distinção entre performance e uma ação não representacional e ao vínculo entre representação e teatralidade, o que implicava pensar as possibilidades de se realizar uma ação ou procedimento teatral que não fosse representacional. Além disso, se apresentavam, para nós, questões concernentes à relação entre o conceito de representação e a noção de espetacularização da vida social e do corpo. Nesse sentido, foi de extrema importância o trabalho de dança criativa - proposto para o agrupamento por uma de nossas pesquisadoras, Patrícia Sene - que nos possibilitou buscar esse aprofundamento conceitual a partir de nossa prática corporal e engendrar caminhos que permitissem ao corpo entender.

\footnotetext{
O trabalho corporal da dança criativa com fundamentos de Bárbara Mettler é uma livre abordagem à arte do movimento corporal, valoriza a criatividade, a improvisação, a organicidade e a integração rítmica do corpo em movimento (...). Sempre a partir de problemas de movimento, improvisações são realizadas objetivando a consciência e o controle do movimento em relação aos elementos espaço, tempo e força. Não há a repetição planejada de formas de movimento, mas a repetição pode existir se for orgânica ${ }^{47}$.
}

No âmbito da minha investigação, a pesquisa do movimento proposta por Patrícia foi esclarecedora, pois serviu como uma resposta concreta e prática às questões teóricas que a leitura de Barrio/Barriga havia me colocado em relação aos princípios que regeriam uma possível composição de ações a partir da idéia do corpo atuante. Para a investigação de uma ação não representacional, o trabalho de dança criativa concretizava, a partir da experimentação no corpo de um movimento puro, desligado de quaisquer sentidos ou significações - livre de uma coreografia ou cartografia do movimento - a possibilidade de explorar as relações do corpo com o espaço da cidade, os materiais produzidos nesta relação e os rastros deixados na cidade.

O contexto da cidade, devido a suas dinâmicas e potência de penetração no tecido da cena, implica sempre na sua formulação como dramaturgia. A cidade é dramaturgia porque é produtora de sentidos. [...]

\footnotetext{
${ }^{47}$ SENE, Patrícia. Agrupamento de ações: aceita um café? (artigo inédito). Belo Horizonte: 2008.
} 
Essa escritura é realizada pela ação imagética da arquitetura - pela presença do aparato urbano construído - pelas ações e atitudes dos sujeitos que ocupam os espaços da cidade, e pela força dos discursos institucionais que tratam sempre de dominar a construção da paisagem urbana (CARREIRA, 2009: 4).

Para o desenvolvimento de uma percepção dramatúrgica na relação com a cidade, foi especialmente fértil a caminhada performática proposta por Clóvis Domingos. Especificamente no que concerne à minha pesquisa, a primeira caminhada, realizada no centro da cidade (ambiente sujo e "mal-freqüentado"), produziu um salto na investigação de uma textualidade in process, cujo suporte material passou a ser o corpo da cidade e os elementos que o compõem - asfalto, parede, tapumes, placas de trânsito - e cujo eixo temático não era mais a mulher marginal, mas a mulher padrão, centro do consumo capitalista. Ou seja, dos elementos explorados por mim, durante a caminhada, nasceu a percepção - iluminadora para o prosseguimento da pesquisa - de que era justamente a mulher objeto - objeto não somente sexual, mas também doméstico - que é própria de todas as sociedades patriarcais e, muito especificamente, da sociedade de consumo atual, que iria constituir a margem não discutida, porque naturalizada. Visto como um aspecto intrínseco à natureza humana, esse feminino não se configura, para a sociedade, como um problema.

A margem é aqui. No centro da cidade. Nas ruas de cada dia mulheres são construídas, mulheres de cada dia. Mulheres de cama e mesa. Sobremesas. Valem tanto como um bombom sonho de valsa. Baixou. 20 centavos. [...] Vejo o casal que se abraça. Que pena, tivesse visto antes e deixaria meu buquê de vinte centavos para ela. Futura noiva domesticada pela tv se deus quiser. [...]

Mulheres de plástico não passam por aqui. Mulheres papelão? Mulheres notícias de jornal? Mulheres vendem cerveja. Pneus. Carros. Cigarros. Bombons, margarina, e a promessa de um casamento feliz. Ou pelo menos um amor padrão global. Mulheres domesticadas pela novela. Filés. Gostosas. Boas de comer. Devorar. [...] Um pedaço de carne 
embrulhada em roupas de seda, algodão, não importa. Ela vai ser despida. A carne também é dócil e muda ${ }^{48}$.

O mecanismo da caminhada, utilizado ainda mais duas vezes naquele mês, e as questões que a primeira experiência desencadeou funcionaram como centros geradores de um processo criativo que teve início na mostra de junho. Além da própria caminhada, geraram caminhos metodológicos para a estruturação de uma dramaturgia inscrita no espaço alguns relatos produzidos em decorrência da experiência vivida, como o de William Neimar, no qual ele faz uma comparação entre a ação realizada e a obra de Calvino, Cidades Invisíveis, especificamente a cidade dos mortos, Eusápia, simulacro perfeito da cidade dos vivos.

Objetos falecidos pela perda da função na vida prática e ordinária esquecem-se de servir, se abandonam e somem diante dos olhos quase cegos do dia-a-dia que só vêem sinal fechado, outdoor arreganhado, promoção de camisinha e modelos de beleza. [...] Um grupo quase silencioso caminha recolhendo cadáveres. A caminhada performática enxerga o chão, a doentia sub-cidade. Depois de adentrado o mundo dos mortos não se deve olhar para trás, porque estátua e pedra eternizam qualquer mitologia, tornam centro a margem, clássico o barroco, sublime o grotesco. [...] Nas paradas, nas estações, nos campos Elíseos, um de cada vez, instalando os objetos de acordo com a vontade aleatória do gesto. O proponente escolhe o lugar, mas a ordem define aquele que recolheu os restos. Todos parados assistindo a construção da obra. Pronta a instalação, cada corpo dono do que construiu se posiciona na feitura: espetáculo ou acontecimento? Os vários mortos objetos escolhidos por cada pessoa, quando re-dispostos juntinhos, trazidos à cena, retornavam ao mundo dos vivos. Então, são observados, observáveis e viram arte [...]. A perda da função assassina tudo. A função da arte ressuscita algo? ${ }^{49}$

\footnotetext{
${ }^{48}$ Relato pessoal da primeira caminhada performática, postado por mim no dia 27/05/2008, no blog do Obscena: www.obscenica.blogspot.com.

${ }^{49}$ Trechos do relato de William Neimar, postado postado no dia 31/05/2008, no blog do Obscena (ver relato completo em: www.obscenica.blogspot.com).
} 
A comparação entre objetos produzidos pelo consumo e corpos mortos gerou, para mim, uma imagem fortíssima que, concretizada em uma proposta de instalação para a mostra de junho, serviu de gérmen para aquilo que comecei a denominar, a partir da expressão cunhada por José Da Costa em sua tese de doutoramento, como uma escritura cênico-dramatúrgica conjugada. Segundo José Da Costa, essa expressão tem seu diapasão conceitual "dado fundamentalmente pelas idéias de processualidade, de interatividade e de simultaneidade de criações entendidas tradicionalmente como seqüenciadas ${ }^{50}$ ". Ou seja, na criação cênico-dramatúrgica conjugada, tanto a processualidade como a simultaneidade das produções dramatúrgica e cênica - na qual está incluído o campo atoral - tendem a atenuar, no processo de experimentação e criação, as hierarquias e fronteiras entre o campo literário - "a reflexão dramatúrgica, a criação verbal" - e o trabalho performativo (DA COSTA, 2003: 16). Tais aspectos pareciam, a meu ver, dar conta das características do trabalho realizado por mim e por Lissandra que gerou a intervenção Mulheres Mortas ${ }^{51}$.

Quanto ao experimento, realizado durante a mostra de junho, era constituído por uma instalação estruturada a partir de desenhos, feitos a giz no chão, de corpos de mulheres deitadas. Marcas que remetiam diretamente aos índices de posição e queda do corpo morto que são produzidos em decorrência de assassinatos. Os corpos, desenhados por mim a partir das mulheres espectadoras/transeuntes que por ali circulavam, eram posteriormente preenchidos com escritas e completados por objetos - embalagens - de produtos femininos.

\section{Proposta para uma ação/situação dramatúrgica.}

Narrativas jornalísticas poéticas científicas dicionarescas inventadas documentais. Embalagens plásticas metalizadas produtos de limpeza cosméticos mantimentos eletrodomésticos utensílios do lar higiene pessoal familiar. Marcadores. Pincel. Giz.

O corpo blindado estetizado mediatizado embalado plastificado possuído. Dia dos Namorados C\&A celular. Preços que vão pegar você de jeito. Cem mil crianças e adolescentes são explorados sexualmente no

\footnotetext{
${ }^{50}$ DA COSTA FILHO, José. Teatro brasileiro contemporâneo: um estudo da escritura cênicodramatúrgica atual. Tese (Doutorado em Literatura Comparada) - Instituto de Letras, Universidade do Estado do Rio de Janeiro, p. 16.

${ }^{51}$ Nomeado inicialmente de Cidade das mortas, em referência ao relato de William Neimar.
} 
Brasil. Enterrada menor de treze anos, estuprada e morta. O objeto morto. Simulacro. Na sua origem, a imagem é o simulacro de um morto: imago. A imagem duplicada. Esse corpo imagem morto objeto em construção. Duplicação. Repetição. Ser mãe é padecer no paraíso. Repito. A mãe é a culpada de tudo. Repito. Mulher é mais delicada. Homem é mais animal. Repito. São todos iguais. Repito. Mulher também: são todas iguais. Bonequinha. Coisinha linda. Ficou tão bonitinha de vestido. Não importa se embrulhada em algodão ou seda. É um filezinho. Uma gatinha. Gostosa. Gostosa. Carne embrulhada em papel de presente. É importante não perder a ternura jamais. Não perder a doçura jamais. A sensualidade da mulher jamais. Sua feminilidade jamais. A dor e a delícia de ser o que é. Mortos a fabricar mulheres. Mortas. Na embalagem. No plástico. No lixo.

E as margens pulam para o centro.

Corpos de mulher. Instalações de objetos e narrativas. Escritas do momento? As notícias recortes de jornal? ? $^{52}$

Era visível a potência produzida pela caminhada performática. Não somente para mim, mas para todos os pesquisadores do agrupamento cujas proposições futuras foram por ela influenciadas. É exemplar a ação que, nessa mesma mostra, foi experimentada por Lissandra Guimarães a partir da idéia de um corpo-instalação: com o corpo construído por bacia, vassoura e outros objetos do universo feminino, Lissandra fez um percurso pelo hiper centro da cidade, saindo da Casa do Conde, passando pela Avenida Afonso Pena e chegando ao Teatro Marília em torno das vinte horas. A percepção do impacto da sua ação, registrada por Túlio Drummond videomaker que se interessara em acompanhar alguns de nossos trabalhos - e pelo pesquisador Moacir Prudêncio, só foi possível quando assistimos ao vídeo. Importante salientar que a percepção de Lissandra, no que diz respeito à reação das pessoas durante a realização da ação, foi completamente distinta do efeito real provocado por ela, perceptível no registro de sua passagem. Lissandra tivera a impressão de que não houvera, por parte dos transeuntes, estranhamento em relação à figura dela. Ao assistirmos ao vídeo, porém, é evidente o modo como sua passagem provocava reações, ainda que as pessoas não a confrontassem diretamente, com palavras ou com o olhar.

\footnotetext{
${ }^{52}$ Trecho do relato pessoal postado no dia 10/06/2008, contendo proposta a ser realizada na $2^{\underline{a}}$ mostra processual de pesquisa, em junho. Ver relato completo em: www.obscenica.blogspot.com.
} 


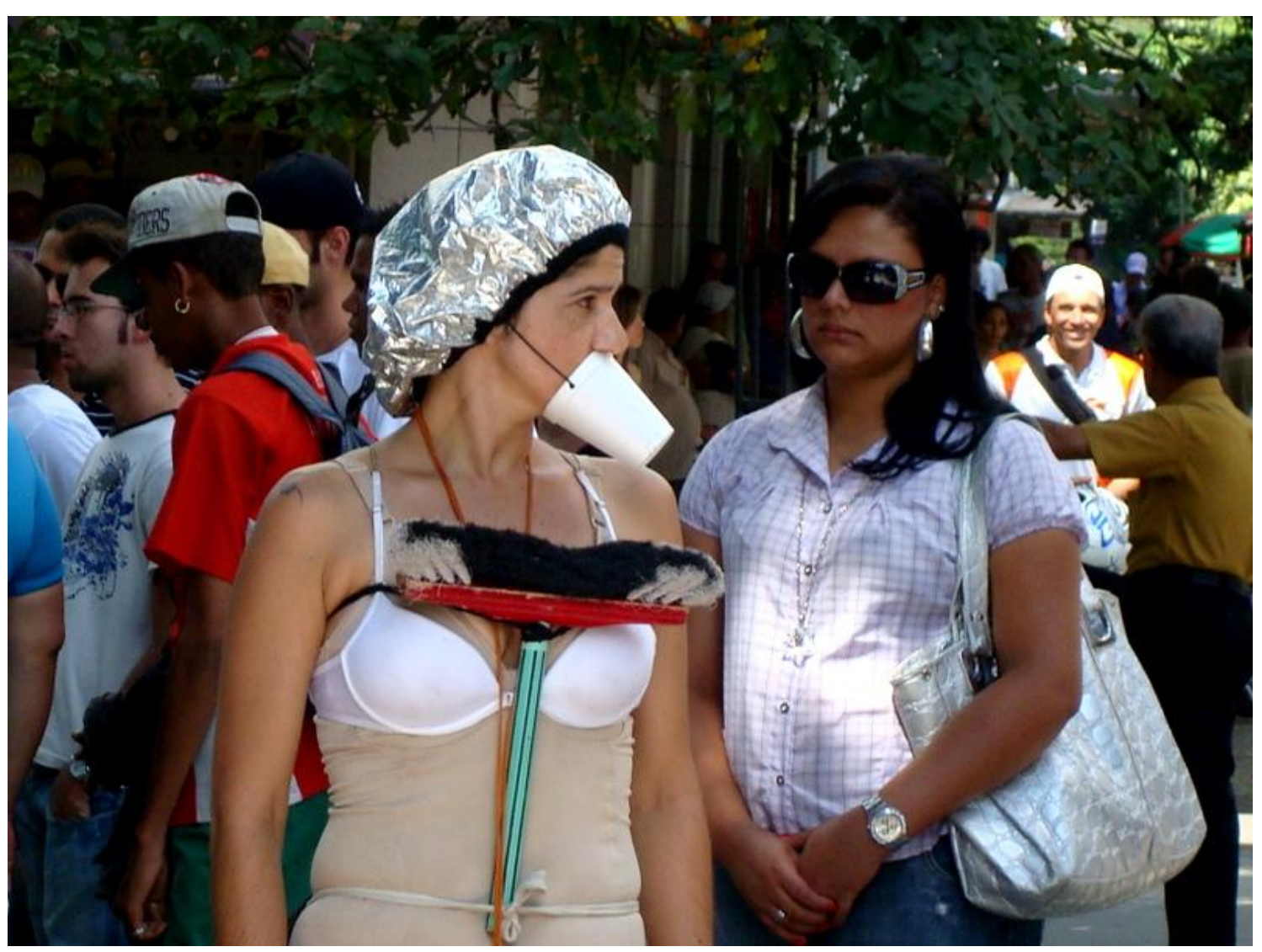

FIG. 1o. Lissandra Guimarães: corpo-objetos. Foto de Davi Pantuzza

A partir da mostra de junho, firmou-se o propósito, meu e de Lissandra, de investigarmos, em diálogo de criação, os elementos que tínhamos começado a desenvolver de maneira individual: ela, por meio das relações de seu corpo mulherobjeto com os espaços da rua (monumentos, passagens, paisagens) e eu, por meio das relações entre esse corpo-instalação, os corpos mortos desenhados no chão a partir dele e as escritas produzidas no calor do momento, com as quais eu preenchia os desenhos marcados a giz. A investigação prática, no entanto, só começaria, efetivamente, em agosto. Transcrevo abaixo trechos do relato da primeira experiência, realizada na rua no dia 19.

Eu armada com meu instrumento: o giz, colocado singelamente numa embalagem de creme para cabelo: Hair construtor.

Eu também me aqueço, preparo meus instrumentos. É necessário selecionar narrativas a serem experimentadas. Os anúncios das prostitutas de Curitiba devem percorrer esses corpos mortos, desenhos a 
giz no chão. Também deve estar lá o verbete do Aurélio. Também quero: a gente pensa que é mulher e é só fêmea, bichinho de estimação. Também quero: uma mulher é feita de arestas, becos, buracos. Voz, carne e sangue. E osso e pele. Quero brincar com o inventário de tarefas inúteis e com os desejos de consumo da mulher: depilação a laser, botox, jet bronze, diet, light. Quero colocar os discursos em choque, jogar com as manchetes e com as estatísticas: Enterrada menor de treze anos, estuprada e morta. Cem mil crianças e adolescentes são explorados sexualmente no Brasil. [...]

Nosso trajeto: do Marília à Estação. Pela Afonso Pena, paradas no caminho. Corpos. Escritas. Em frente ao Café Nice a mulher objetos foi ovacionada como uma miss no desfile de finalista. Ah, os homens! Ali nos pareceu um ótimo lugar para deixar nossas mortas. A mulher objetos larga suas inúmeras sacolas e deita-se no cimento liso. Desenho um belo corpo no chão e começo a preenchê-lo: mulher ser humano do sexo feminino capaz de conceber e parir outros seres humanos e que se distingue do homem por essas características. Mulher da vida: meretriz. Mulher à toa: meretriz. Mulher. Meretriz...

[Depois] ela atravessa a grande avenida, avança para a [praça da] Estação. Caminha entre os pontos de ônibus e deita-se na passagem dos pedestres. Afeiçoei-me às passagens de pedestre. $\mathrm{O}$ chão é liso e inclinado. O espaço é razoável e atrapalhamos o trânsito. A última morta, deixamos sob o viaduto de Santa Tereza: Samy, 20 anos. Morena mestiça. Sapeca e safada. É preciso ser mulher até o osso.

Deixamos o último traço e partimos. Eu bastante feliz. Achei o fio dessa meada. Hoje até vou ao Maletta. É preciso beber as mortas ${ }^{53}$.

Fizemos, ainda em agosto, mais algumas dessas intervenções nas ruas e praças da cidade, nas quais Lissandra experimentou a criação e o trânsito entre o que ela denominava de corpos cênicos, produzidos a partir das relações do seu corpo com os objetos. No dia 21 de agosto, por exemplo, ela começou a testar a passagem de um corpo-noiva, construído a partir de embalagens plásticas, ao corpo cênico já experimentado anteriormente. Também em agosto, após conversa com a pesquisadora Erica Vilhena - na qual ela relatou uma visita que, na infância, havia feito com a mãe a uma exposição de bonecas de todos os tipos - eu comecei a vislumbrar uma estrutura

\footnotetext{
${ }^{53}$ Relato pessoal, postado no dia 19/08/2008, no blog do Obscena: $\underline{\text { www.obscenica.blogspot.com. }}$.
} 
de ações maior, a ser tecida no diálogo entre meus corpos-escritas a giz e possíveis ações a serem desenvolvidas por outras atrizes do agrupamento, a partir da idéia de uma "exposição de bonecas". Eu já havia experimentado uma composição de ações semelhante a esta, ainda que de maneira incipiente e, de certo modo, superficial, na primeira mostra processual, realizada em abril. Agora, no entanto, a estrutura se desenhava de uma maneira absolutamente precisa em minha cabeça, a partir da relação entre corpos mortos e mulheres-bonecas, ou seja, mulheres fabricadas pela sociedade: "Corpos mortos na paisagem da cidade. Mulheres bichinhos de estimação. Mulheres bonecas em exposição. Mulheres noivas. Mulheres rol. Registros de nossa passagem, marcas do nosso diálogo ${ }^{54 "}$.

Em setembro, começamos a realizar as mostras de pesquisa, públicas e semanais, que havíamos acordado a partir da avaliação das mostras anteriores que, em nosso entendimento, tinham adquirido um caráter de "apresentação". A cada segundafeira, um pesquisador ou núcleo de trabalho realizava sua experimentação, que era acompanhada pelos outros integrantes do agrupamento. Estes se comprometiam, então, a lançar provocações para o amadurecimento do trabalho, nas reuniões de avaliação e em relatos postados no blog. Com a abertura dos trabalhos práticos, ocorrida em todas as segundas-feiras de setembro e outubro, ou seja, no dia-a-dia da experimentação, da pesquisa em ação de cada um de nós, conseguimos atender, a meu ver, à dimensão não somente pública, mas também processual inerente ao trabalho de pesquisa que havíamos nos proposto a realizar.

Dentro da programação, feita de modo a atender todos os pesquisadores, realizamos, eu e Lissandra, nos dias 15 e 29 de setembro, mais algumas pesquisas práticas em torno de Mulheres Mortas. Como em agosto já havíamos experimentado trabalhar no fim de tarde/início da noite - horário em que há um fluxo intenso de pessoas saindo do trabalho - e considerado profícuas as interações que havíamos obtido com o público transeunte, optamos, no dia 15, por começar o trabalho às cinco horas, na Praça da Estação e avançar, posteriormente, para a Praça Sete. Nesse dia, havíamos solicitado o registro de nossa intervenção ao videomaker Fernando Sette que, como Túlio Drummond, vinha acompanhando alguns dos trabalhos do

\footnotetext{
${ }^{54}$ Relato pessoal, postado no dia 26/o8/2008, no blog do Obscena: www.obscenica.blogspot.com.
} 
agrupamento. Contudo, o simples ato de registrar acabou por caracterizar a ação como evento, aos olhos da Guarda Municipal responsável pela segurança e controle da Praça da Estação. Ao ser caracterizado desse modo, o trabalho passou, automaticamente, a demandar autorização para ser realizado: “evento tem que ter autorização”, afirmava a Guarda Municipal. Uma vez que a intervenção estava caracterizada como evento, também passou a precisar de autorização toda palavra que, em decorrência dela, fosse impressa no chão da praça. Sem dúvida, para a Guarda Municipal, a palavra escrita, o registro de nossa passagem e do meu olhar, eram marcas inegáveis de uma subversão da ordem, pois, como afirma Foucault, "os discursos [os textos, os livros] começaram a ter realmente autores [...] na medida em que o autor podia ser punido, ou seja, na medida em que os discursos podiam ser transgressores ${ }^{55 " . ~ E ~ a ~ e s c r i t a, ~ " d e s a u t o r i z a d a ", ~}$ necessariamente transgredia: era dano ao patrimônio público, era pichação. Ainda que fosse feita a giz...

Diante da exigência de autorização - e sem conseguir romper o controle do espaço - resolvemos partir para a Praça Sete, um olho do furacão onde o chão é liso e possível a escrita. Nessa praça, reformada para descentralizar o centro, o fluxo de passantes nos engole e esconde, permitindo o circo, pois ali se instalavam o pastor evangélico, os skatistas, o vendedor ambulante, as "estátuas vivas" que produziam, a partir de suas interações, um acontecimento ao qual nos integrávamos. Como afirma André Carreira, "tudo que ocorre na cidade cria imediatamente uma rede de contatos e de comunicação que vai definir os sentidos do acontecimento ${ }^{56 ”}$. Assim, buscando perceber essa paisagem não "como um quadro de imagem, mas como um entorno que envolve aqueles que constroem o ambiente" (CARREIRA, 2009: 4), optamos por realizar um circuito que nos possibilitasse percorrer toda a arquitetura da Praça Sete, seus monumentos, e terminar na monumental M MacDonald's, no monumental M Mulher.

Estávamos em frente à McDonald's. Eu escrevia. A Mulher objetos postava-se em frente ao $\mathrm{M}$, seu corpo, arquitetura viva, compondo o espaço. M. Mulher Sanduíche. M. Mulher Filé. M. Mulher da rua. Mulher da zona. M. Meretriz. Mulher da comédia. Meretriz. Mulher à toa.

\footnotetext{
${ }^{55}$ FOUCAULT, 2006: 275.

${ }^{56}$ CARREIRA, 2009: 2.
} 
Meretriz. Mulher da vida. Mulher. O ser humano do sexo feminino que concebe e gera outros seres humanos e que se distingue do homem por essa característica. M. Mãe. M. Muda. M. Morta. Disque M: Karla, 35 anos, 2 filhos, morta a facadas pelo ex-marido. Luciana, 18 anos, 1 filho, morta com um tiro no peito pelo ex-marido. Precisamos explorar mais a Praça Sete ${ }^{57}$.

Com a vinda de Antônio Araújo, ainda em setembro, para uma consultoria dentro do projeto Laboratório: Textualidades Cênicas Contemporâneas ${ }^{58}$, busquei aprofundar - a partir dos férteis debates que travamos acerca das práticas de intervenção urbana - minhas questões sobre os fluxos relacionais e poéticos da dramaturgia e do dramaturgo no curso da ação performativa, ao operar entre o fluxo de leitura do espectador e o fluxo de escritura do autor. Outros aspectos da discussão disseram respeito à materialidade do texto e à sua potência como estrutura organizadora dos sentidos, além da necessidade de se elaborar textos fixos - um repertório mínimo com o qual eu pudesse jogar no trabalho de escritura - a partir das matérias textuais utilizadas na criação: notícias de jornal, verbetes de dicionário, bulas de remédio, classificados de prostitutas, listas e rol, placas de trânsito, de obra civil e outras marcas de inscrição do ambiente urbano. Tendo essas questões como apontamentos para minha investigação de uma dramaturgia no corpo da cidade, propus que nos lançássemos, na ação do dia 29 de setembro, na experimentação de uma nova região de Belo Horizonte, considerada centro do consumo da classe média da cidade: a Savassi.

Além disso, parecia-me urgente pensar, para além do processo de criação das escritas produzidas por mim, na natureza específica dos textos resultantes desse

\footnotetext{
${ }^{57}$ Relato pessoal, postado no dia 19/o9/2008, no blog do Obscena: www.obscenica.blogspot.com.

${ }^{58}$ Com curadoria minha e do professor Fernando Mencarelli, da Escola de Belas Artes da UFMG, O Laboratório fez parte de um conjunto de ações de fomento às artes cênicas contemporâneas, realizadas, de 2006 a 2008, pelo Projeto Arte Expandida da Diretoria dos Teatros Municipais. A partir de experiências de ocupação/intervenção realizadas por núcleos de criação independentes, em espaços públicos de Belo Horizonte - do Teatro Francisco Nunes a espaços urbanos não destinados à cena teatral - o projeto Laboratório propunha a discussão, por meio de textualidades cênicas diversas, dos espaços públicos, da cena teatral contemporânea e da ação dos teatros municipais. Faziam parte da estrutura do projeto, seminários e workshops com pesquisadores importantes do teatro contemporâneo, como Luiz Fernando Ramos e Antônio Araújo, ambos da ECA/USP, Fernando Villar, da UnB e Christine Greiner, das Artes do Corpo-PUC.
} 
processo, ou seja, no aspecto formal que adquiria as textualidades produzidas no calor da ação, a partir do repertório de matérias textuais diversas e dos fluxos e dinâmicas relacionais produzidas no processo de escritura. Em outras palavras, para descrever os textos inscritos nas marcas de corpos femininos - também elas uma forma de inscrição - parecia ser necessário um conceito que desse conta não somente do seu modo de produção, mas também de suas características propriamente formais. No que concerne a esse aspecto, a noção de escritura cênico-dramatúrgica conjugada não pareceu suficiente, uma vez que ela se refere, antes, ao trabalho de criação de um roteiro ou script de uma encenação e, nesse sentido, privilegia sobremaneira as características desse texto cênico, o que é evidenciado pelos exemplos citados por José Da Costa, tais como os espetáculos encenados por Gerald Thomas, Renato Cohen ou Antônio Araújo, do Teatro da Vertigem. Já o conceito de texto escritural, como pensando por Barthes, não só ajudou a elucidar o problema, como apontou determinados aspectos que acabaram por contribuir para o desenvolvimento da noção de escrita performada.

Segundo ele, são características do texto escritural: a possibilidade de “subversão na e pela linguagem” (BARTHES, 1996: 52); as destruições gramaticais de ordem sintática e morfológica (BARTHES, 2006: 13); as (re)construções que provocam instabilidade normativa no seio da estrutura escritural, a re-escritura ou restauração perpétua do texto; a ausência da narrativa linear, fixa, preocupada em explicar uma história com início meio e fim; um prazer ou gozo na leitura que pode ser atópico (BARTHES, 1996: 35), ou seja, não pode ser fixado por nenhuma mentalidade. Ao apontar esses aspectos, Barthes permite pensar nas marcas processuais que carrega o texto - toda forma de inscrição - ao ultrapassar não somente os limites da folha de papel, mas também os limites da literatura e de uma narrativa linear. Assim, ao se constituir por meio dos fluxos relacionais ancorados nas dinâmicas produzidas entre o performer e o espectador-transeunte, nas relações entre o processo de escritura e o processo de leitura, o texto se produz na e pela performatividade da ação, carregando, por conseqüência, as marcas dessa relação em seu bojo. Transcrevo abaixo, na íntegra, o texto relato da experiência ocorrida no dia 29 de setembro, em função das características que nele percebo como escriturais. 
Esse corpo mulher sacolas perambula pelas lojas do Pátio Savassi. Gravar não pode. Só o celular democrático de uso geral. Todo mundo tem câmera Bluetooth mp3. As caras nas câmeras redes de TV. A câmera caracteriza normaliza o acontecido. Este se torna evento. Teatro arte propaganda marketing novela das oito. Filme. No mundo do mercado o mercado explica tudo? É necessário criar o atrito. O estranhamento. Essa mulher produzirá sonoridades corporalidades animais.

Por que você está vestida assim? E você? Por que a prancha escova progressiva inteligente jeans da moda o roxo bata pode. Por que o sexo forçado marido namorado um tapinha não dói. Homem faz sexo mulher faz amor lipoaspiração drenagem linfática. Tintura. Depilação epilação hidratação cauterização ballayage plástica botox silicone. Não é possível explicar, desculpe o transtorno. Estamos trabalhando para você.

Descemos a rua em atrito com as lojas que encontramos pelo caminho. Drogaria Araújo. A mulher super vaca maravilha rebola reboa seu sino nos corredores vidros prateleiras produtos. A ação é sutil. O som na drogaria. A pose em frente às lojas da Rede. Em frente à Travessa, o diálogo com a estátua da mulher escritora. A prateleira de bonecas da loja de brinquedos. Aqui, as escritas se multiplicam, geradas pelo atrito contato com esses mundos. Materiais. A prateleira rosa. $\mathrm{O}$ banquinho branco em frente aos contos de fadas da melissa. A estátua escritora e a boneca de papel da propaganda de desodorante.

Mulher. Uma obra em construção.

Quem é a obra de quem?

Filé. Delícia. Gostosa. Carne de primeira. Gatinha. Cachorra. Cadela. Vaca jaca galinha piranha. Mulher melancia. Mulher da vida. Mulher da zona. Mulher da comédia. Mulher à toa. Mulher. A esposa em relação ao marido. Moça que atingiu a puberdade. Samy. 18 aninhos. Morena gostosa. Safada, sapeca como você gosta. 100\% completa. Sexo anal total. 69 gostoso. Foto original sem retoque. Gosto de beijar. Amar. Cuidar. Transar. Mesmo sem vontade. Esquecer. Perdoar. Compreender. Sujeitar. Sacrificar. Esquecer. Esquecer. Embalar. Adestrar. Ensinar. Mesmo sem vontade. Educar. Amamentar. Brincar. Parir. Amar. Limpar. Passar. Jogar no rio. Na privada. Na esquina. Na esquina.

Desculpe o transtorno estamos trabalhando para você. Uma obra em construção. Barbies. Pollys. Princess all globe. Bonecas domesticadas pela TV. Hidratantes. Desodorantes. Perfex. Batom. Antiaderente. Drenagem linfática Jet bronze endermologia com arte é diet light in out enterrada 
menina de 14 anos encontrada morta e estuprada. Metida. Fodida.

Arregaçada. Como você gosta.

Cerveja. Boa. Gostosa. Gelada.

Chega de fruta. Homem gosta é de comer carne ${ }^{59}$.

O relato, como texto-testemunho da intervenção realizada no dia 29, evidencia, no meu ponto de vista, a extrema potência do experimento que Lissandra e eu tínhamos estabelecido a partir da relação entre escrita e ação, entre as "mortas" que se multiplicavam pelas ruas e esse corpo objetos em suas diversas possibilidades de atuação: de uma ação concentrada em determinado espaço ao nomadismo e à invasão de lojas, espaços privados do consumo imediato. Após essa experiência, a imagem de uma exposição de bonecas se fortaleceu ainda mais. Propus, então, às pesquisadoras Erica Vilhena e Joyce Malta uma ação integrada ao trabalho que já vínhamos desenvolvendo. Abaixo transcrevo o email que enviei numa tentativa de organizar uma proposta ainda muito incipiente, mas que já continha alguns elementos provocadores para o ambiente em que, a partir da última experimentação, novamente atuaríamos: a Praça da Savassi, na qual circulavam - segundo nossa perspectiva - diversas mulheres fabricadas em série, bonecas domesticadas pela TV, que desejávamos colocar em “exposição” no confronto com nossa ação.

“... eu vou interagir com as instalações das três. não sei se vocês ficarão juntas ou separadas, mas penso que próximas é necessário, para configurar um único acontecimento: a exposição. como se fossem nichos, prateleiras ou vitrines. podemos andar com a exposição pelos quatro cantos da praça e cercanias.

Vou trabalhar com escritas em papel de propagandas e com o giz no chão. Vou querer que, às vezes, vocês se deitem e eu possa desenhar seus corpos no chão e escrever. O trabalho demandará um tempo. Podemos alternar suas ações e minhas escritas no chão. Enquanto desenho uma, para escrever a partir dela, as outras continuam em ação. Podemos também alternar a isso, uma ação conjunta. Os três corpos deitados no chão, por exemplo.

\footnotetext{
${ }^{59} \mathrm{O}$ relato/roteiro de trabalho integra a postagem Setembro das flores, do dia 30/09/2008. Ver em:
} www.obscenica.blogspot.com. 
PROPONHO ESSA AÇÃO COMO UMA ESTRUTURA DE DIÁLOGO COM OS MATERIAIS DAS ATUANTES. NÃO QUERO CORPOS AO MEU SERVIÇO. PROPONHO O ESTABELECIMENTO DE UM DIÁLOGO EM TRABALHO. DE UMA ESCUTA DOS CORPOS E DAS POSSIBILIDADES DE AÇÃO DO OUTRO E COM O OUTRO. A PREPARAÇÃO SE FAZ NECESSÁRIA.

Enfim, essas são as questões que estou pensando...

Evocês?" ${ }^{\prime 60}$

Da experiência concreta, realizada no dia 13 de outubro - não foi por acaso a proximidade com o Dia das Crianças - muitas coisas interessantes e potentes surgiram. Os corpos das performers no chão, atuando em conjunto, tornavam a imagem de mulheres mortas mais visível e chocante. Efetivamente, o conjunto pareceu bem favorável, em vários aspectos: além de estabelecer uma noção de série - como nas bonecas de plástico que Joyce manipulava, colocando o corpo dela como mais um corpo plastificado - e de reprodução de estereótipos - o corpo martirizado de Erica, apertado pelas roupas pequenas demais e pelo salto alto, corpo escultura dotado de felicidade idiota diante das câmeras de registro - ele potencializava, também, a idéia do acontecimento performativo como uma "prática de invasão da cidade. Essa invasão é uma interferência na lógica da cidade, uma intromissão ao uso cotidiano dos espaços ${ }^{61 ”}$.

Era perceptível a imensa potência dessa exposição de bonecas, dessa estrutura aberta que articulava nossas ações em uma rede colaborativa, por meio de um diálogo que acontecia no aqui e agora, no calor da rua, nossa sala de ensaio. Interessava-me, sobretudo, isso: que essa obra se fizesse assim, do cruzamento de nossas vozes autônomas. De nossos fluxos independentes, mas em permanente fricção. No âmbito da dramaturgia, a questão principal que me instigava a continuar a experimentação dizia respeito ao meu estatuto, enquanto atuante, e ao meu lugar dentro da ação. $\mathrm{Ou}$ seja, eu questionava se deveria assumir, mais do que um olhar obsceno - autora espectadora filtrando a paisagem urbana - a presença do meu corpo no fluxo da ação, um corpo dramaturga em fluxo de escrita.

\footnotetext{
${ }^{60}$ Email pessoal do dia o6 de outubro de 2008.

${ }^{61}$ CARREIRA, André. Teatro da invasão: redefinindo a ordem da cidade. IN: LIMA, Evelyn F. Werneck. Espaço e Teatro: do edifício teatral à cidade como palco. Rio de Janeiro: 7 letras, 2008.
} 
Para responder essas questões e experimentar as potências percebidas na ação realizada em outubro, mais uma vez recorremos à investigação prática e intervimos, a partir da estrutura agora denominada de Baby Dolls, uma exposição de bonecas, na vitrine do Teatro Marília, no dia 12 de novembro - durante o fórum de compartilhamento das pesquisas do projeto Às margens do feminino: texturas teatrais da beira - e, em seguida, na Praça Sete. O agenciamento de uma enunciação coletiva possibilitou formas múltiplas de significância para além da palavra escrita, pois aqui o discurso adquiria, novamente, seu caráter de acontecimento por meio da suspensão da soberania do significante ${ }^{62}$.

Percebida a potência absoluta da fenda que produzíamos entre as margens do sentido, optamos por realizar a ação mais algumas vezes na Praça Sete e em outros espaços públicos da cidade, buscando sempre lugares de fluxo intenso de pedestres, como a Praça da Rodoviária, as saídas de estações do metrô e as proximidades da Praça da Estação. As possibilidades múltiplas de leitura de nossa ação - “é protesto?" "Isso é alguma propaganda ou pegadinha”, “Ah, é teatro" - levavam os corpos transeuntes a permanecer, como leitores do acontecimento, em busca de significados que, malgrado seu desejo de sentido, permaneciam ocultos. Pois, se o acontecimento é da ordem do corpo e o discurso está para além do verbal (FOUCAULT, 1996: 56), que texto escritura - é esse que se imprime no corpo da cidade?

Todos os dias, nas ruas da cidade, mulheres são construídas. Mulher princesa. Mulher boneca. dócil muda. Mulher rosa. Mulher de cama e mesa. Mulher sobremesa. Mulher para desfrute. Mulher melancia Mulher jaca Mulher melão. Mulher Filé: "Chega de fruta. Homem gosta é de comer carne".

Todos os dias, nas ruas da cidade, mulheres são construídas. Sorriso. Batom Boca Beijo. Faca Tiro. Todos os dias, nas ruas da cidade, mulheres são destruídas. $70 \%$ das mulheres mortas no país são vítimas de seus namorados, noivos, maridos. Amar. Casar. Cuidar. Compreender. Perdoar. Esquecer. Esquecer. Esquecer. Transar. Mesmo sem vontade. Morrer.

Mesmo sem vontade.

\footnotetext{
${ }^{62}$ FOUCAULT, Michel. A ordem do discurso. São Paulo: Edições Loyola, 1996, p. 51.
} 


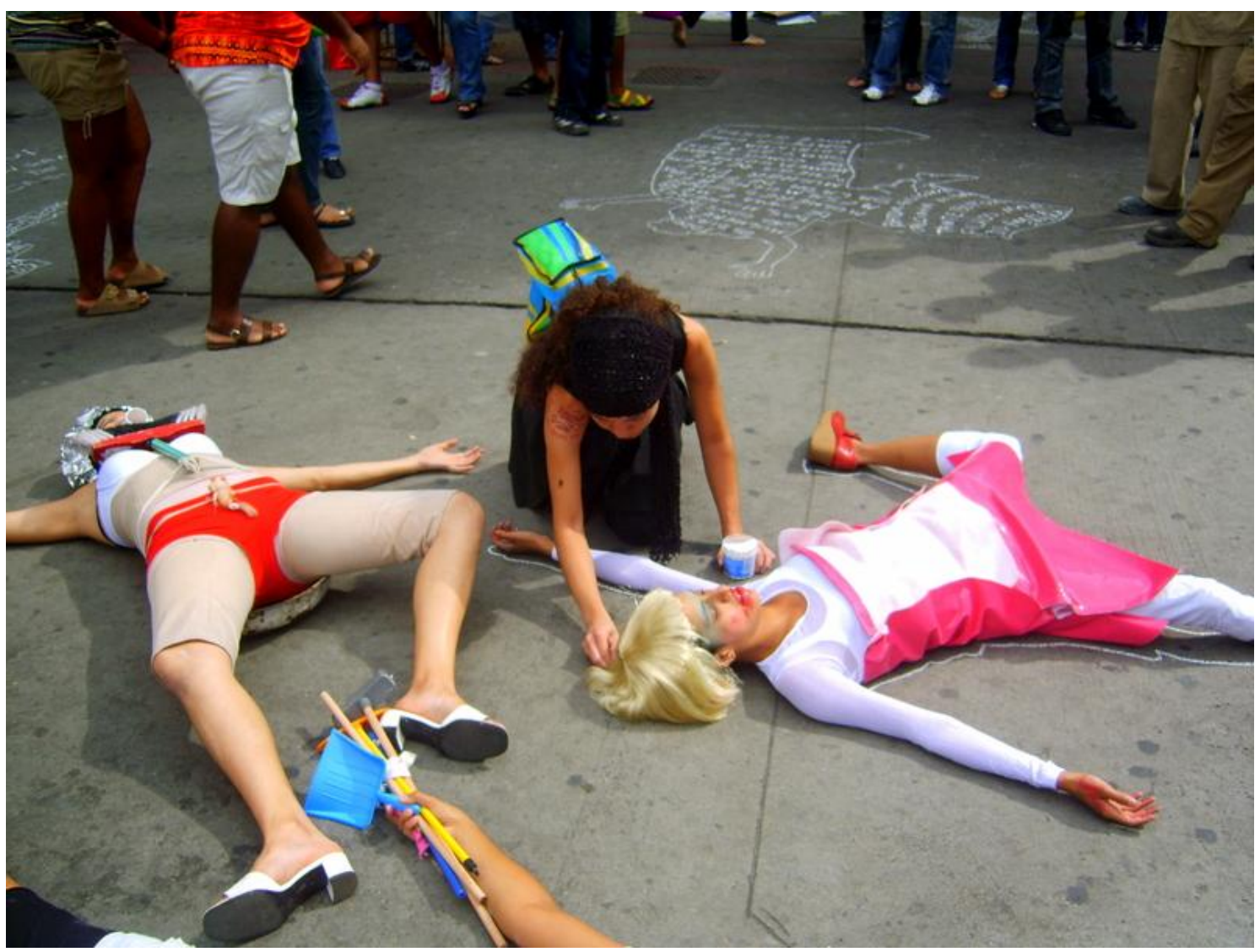

FIG. 11. MIP2: Baby Dolls, uma exposição de bonecas. Foto de Davi Pantuzza

Mulher, uma obra em construção. Desculpe o transtorno, estamos trabalhando para você. Depiladores hidratantes sutiãs rolinhos pregadores talheres gleidy sache vassoura escova progressiva inteligente. Servir bem para servir sempre. Mulher. Ser humano do sexo feminino capaz de conceber e gerar outro ser humano e que se distingue do homem por essa característica. Mãe. A mulher em relação ao marido. Esposa. Plano de saúde, férias, filhos. Feia. Gorda. Jogada fora.

Mulher, uma parcela da humanidade.

Mulher da vida. Meretriz. Mulher à toa. Meretriz. Mulher da rua. Meretriz. Mulher da zona. Meretriz. Mulher da comédia. Meretriz. Mulher. Meretriz.

Engulo tudo sem frescura.

A gente pensa que é mulher e é só fêmea, bichinho de estimação. Gatinha. Cachorra, cadela. Vaca, galinha, piranha. Gostosa. Quente. Pronta para o consumo imediato. 100\% completa. Samy, 18 aninhos. Loirinha e sapeca como você gosta. Adoro beijar. Mesmo sem vontade. 
A cada 2 segundos, uma boneca Barbie é vendida em alguma parte do mundo. A cada 15 segundos, uma mulher é espancada no Brasil. Como você gosta. A cada ano, No Brasil, são feitas 629 mil plásticas. Silicone. Lipoaspiração. Peito. Bunda. Coxa. Como você gosta. Drenagem linfática. Jet bronze. Botox. Diet. Light. In. Out. Enterrada menina de 14 anos encontrada morta e estuprada. Arregaçada.

Como você gosta.

Engulo tudo, sem frescura.

Sarada. Turbinada. Siliconada. Preparada. Espancada. Excomungada. Esquartejada. Jogada pros cachorros. na rodovia. na lagoa. na lixeira. Morta. Como você gosta.

Destruir. Matar. Aniquilar. Dar cabo de. Ex-terminar.

Leonice, 40 anos, 13 facadas, ex-companheiro. Maria Islaine, 31 anos, exmarido. Ele apontou a arma para ela e atirou 7 vezes, sem que ela reagisse. Maria de Jesus, 28 anos, 3 tiros, ex-marido. Luciene, 24 anos, 2 tiros, ex-namorado. Polyana, 23 anos, 18 facadas, ex-marido. Eloá, 15 anos, 1 tiro, ex-namorado. sem que ninguém reagisse. Janine, 16 anos, grávida de 8 meses, morta pelo namorado com pelo menos 42 facadas, sem que ela eu sem que ninguém reagisse.

Amar. Sacrificar. Padecer. Parir. Amar. Amamentar. Cuidar. Limpar. Amar. Jogar fora. É tudo igual, só muda de endereço ${ }^{63}$.

A partir das questões suscitadas pela investigação que realizamos, em 2008, em relação ao corpo da mulher - mas também relativa aos objetos do "universo feminino", aos discursos do poder e à polifonia dos cartazes, classificados e notícias que têm nele o seu centro - tornou-se perceptível, para nós, que sua exposição nos espaços públicos da cidade se apresentava como acontecimento capaz de provocar olhares e reflexões sobre a construção de uma identidade feminina ainda pautada nos ditames de uma sociedade machista e patriarcal, em que a mulher é colocada como objeto de consumo e destruição. Ao se instalar objetos e corpos femininos no corpo da cidade, também se instala uma obra em construção, pois, ao se deparar com esses elementos, com as "tatuagens" que marcam a cidade, são múltiplas as leituras que o espectador-

\footnotetext{
${ }^{63}$ Os textos são parte das escritas performadas produzidas durante as intervenções realizadas ao longo de 2009 e podem ser acessados por meio dos relatos e dos registros fotográficos e áudio-visuais disponíveis no blog e nas redes sociais do Obscena: www.obscenica.blogspot.com ou www.obscenica.ning.com.
} 
transeunte pode realizar - e efetivamente realiza - a partir das imagens produzidas pela ação e das relações que ele trava com elas. Além disso, a intervenção produz "sobras" de sua presença no espaço: restos, rastros, memórias e impressões nos habitantes que participaram da ação, sobras que perduram para além de sua duração.

Já em 2009, realizamos mais três intervenções em praças de Belo Horizonte, nos dias 25 de abril, 16 de maio e 05 de junho. Para o pesquisador Clóvis Domingos ${ }^{64}$ - que acompanhou a intervenção realizada na Praça Sete, em abril, e permaneceu no local para registrar o "depois” da ação - quando os rastros de corpos escritos são deixados no espaço, cria-se uma CENA, posterior à intervenção e independente dela, da qual os transeuntes são, ao mesmo tempo, participantes e espectadores. Escutam-se as pessoas: "é gente doida, mulheres que não gostam de homem, mulheres chamando atenção". Para Clóvis, quando as atuantes abandonam o espaço, elas deixam, nele, uma "escritura da presença" e um fórum de discussões se inicia entre as pessoas que lêem o texto grafado no chão, instaurando um ACONTECIMENTO. Fala-se de tudo: violência, política, corrupção, o que é ser mulher, a covardia dos homens etc. É ele quem afirma:

Começo a marcar o tempo e por meia hora a presença escrita no chão causa fatos e conversas. Um debate sobre a violência contra a mulher. Vejo moças vendedoras de ouro debatendo o trabalho com soldados e o melhor, uma moça se torna uma ATUANTE e passa a explicar o que entendeu para eles. Segundo ela, "é preciso ler de baixo para cima... Assim se entende o texto. Meu filho, eu sou loira, mas não sou burra..." E na explicação dela, aquela "grafia", quase um objeto escrito, ganha mais VISIBILIDADE e cria interrupções variadas. Todos que param recebem explicações dela sobre o que aconteceu e o que significa tudo aquilo. Ela chega a pisar sobre o texto e fazer daquele "espaço escrito", um espaço cênico atraindo a atenção das pessoas... Depois escuto mulheres relatando que já apanharam de homens e falando da Lei Maria da Penha... O fato é que a obra não cessa de causar reações e debates $^{65}$.

Após a última intervenção em Belo Horizonte, realizada em o5 de junho, começamos o circuito de viagens e realizamos, em julho, os festivais de São José do Rio

\footnotetext{
64 Relato de Clóvis Domingos, postado no dia 27/04/2009, no blog do Obscena: www.obscenica.blogspot.com

${ }^{65}$ Ibidem.
} 
Preto e de Ouro Preto e Mariana. Em agosto, de retorno a Belo Horizonte, realizamos uma intervenção pela Manifestação Internacional da Performance, novamente na Praça Sete, e, em setembro, uma segunda intervenção na Praça da Estação. Em novembro, partimos para o Recife, no qual passamos uma semana inteira realizando Baby Dolls nos bairros de periferia e regionais da cidade e experimentando, pela primeira vez, ministrar o workshop Como se fabrica uma mulher? - já aplicado por mim e Lissandra para um grupo de atores, em junho, no Centro Cultural da UFMG exclusivamente para mulheres e contando com a participação de Joyce e Erica, ou seja, pela primeira vez friccionando nossos materiais também no resguardo de uma sala.

Sandra, atriz gaúcha que morava na cidade há seis meses e uma das participantes do workshop, levou, no segundo dia de encontro, um cinzeiro e uma lata de cerveja entre os objetos do "universo feminino" que escolheu para realizar o trabalho conosco. Ela relatou que, ao sair do workshop no dia anterior, tinha resolvido entrar em um bar, sozinha, para tomar uma cerveja e fumar um cigarro. Sandra era a única mulher no lugar. Uma estrangeira, alienígena, pois, em Recife, a população que transita livremente é a masculina. Apesar disso - e, talvez, em razão disso mesmo nunca as mulheres foram tão cúmplices de nós, durante a realização de Baby Dolls, como o foram em Recife. Talvez porque, em Recife, a realidade feminina seja mais dura.

Em Pernambuco, de janeiro a outubro de 2009, 291 mulheres foram mortas. 95\% dos seus agressores foram homens, sendo 70\% companheiros ou ex-companheiros, maridos ou ex-maridos, noivos, namorados. 70\% destas mulheres foram mortas por homens que diziam amá-las. Pernambuco é, atualmente, um dos estados nos quais mais se mata mulheres no Brasil. No Recife, embora haja 100 mil mulheres a mais que homens, tivemos a impressão de predominância masculina porque, as mulheres, não as vemos tanto pelas ruas. Não as vemos tanto pelos bares, desacompanhadas. Em Recife, talvez não seja possível fingir que está tudo bem, que somos emancipadas e que o feminismo é um movimento arcaico e obsoleto. Em Recife, talvez não seja possível ignorar o machismo e fingir que somos donas de nosso próprio corpo e da nossa vontade.

É exemplar da situação da mulher em Pernambuco, um fato ocorrido no primeiro dia de workshop, quando realizamos uma caminhada performática pelo 
Recife Antigo. Andala, uma atriz recifense, havia se postado em uma esquina e do outro lado da rua - ao meu lado, enquanto eu observava à distância - um grupo de homens olhava para ela e um deles dizia: "Aquela ali é puta, tá querendo homem. Vou lá arrumar um pra ela”. Outros homens ameaçavam colocar moedas no "cofrinho" de Erica que, abaixada, registrava tudo. Em Recife, a hipocrisia mineira que permite às mulheres de Belo Horizonte achar, no reverso de narciso, que feio é o que é espelho, não encontra solo fértil para grassar.

No entanto em Recife, como em Belo Horizonte, a potência dessas mulheres unidas desarranja, desconstrói, desordena. Sentimos essa força, em Belo Horizonte, nas intervenções realizadas junto à Marcha Mundial das Mulheres e, em Recife, na Rua da Imperatriz - durante a primeira intervenção - quando as feministas do grupo Loucas de Pedra Lilás aplaudiram Joyce, ao vê-la arrancar a peruca loira e revelar seus cachos crespos, negros. Sentimos sua força em nossa caminhada performática pelo Centro do Recife Antigo e a sentimos no Mercado de Casa Amarela, quando alteramos nossos percursos e relações para fortalecer as imagens de consumo em confronto com os produtos das lojas e açougues do mercado, bagunçando os sentidos de quem por lá transitava. Lá, no Mercado de Casa Amarela, pela primeira vez senti o impulso real e a cumplicidade necessária, isto é, o desejo daquelas pessoas de compartilhar da minha escrita. Corpos vazios foram preenchidos por outras mãos armadas de giz. Esse mesmo desejo e cumplicidade senti, outra vez, durante a intervenção realizada na Praça da Várzea, quando as mulheres avançaram, tomando posse do giz e dos corpos. Potência Performativa a realizar o intuito de produzir uma ação interventiva no cotidiano social, cumprindo a perspectiva de provocar uma atitude ativa do espectador diante do acontecimento.

Numa sociedade em que se multiplicam mulheres comida - Mulher Melancia, Mulher Jaca, Mulher Filé - em que mulheres, vistas como objeto e propriedade, são assassinadas em número cada vez maior, o espectador transeunte, sem respostas claras e um entendimento imediato do que se passa, é obrigado, em certo sentido, a parar e interagir com a ação que visa destruir os estereótipos que se reproduzem e desorganizar as imagens dadas. 


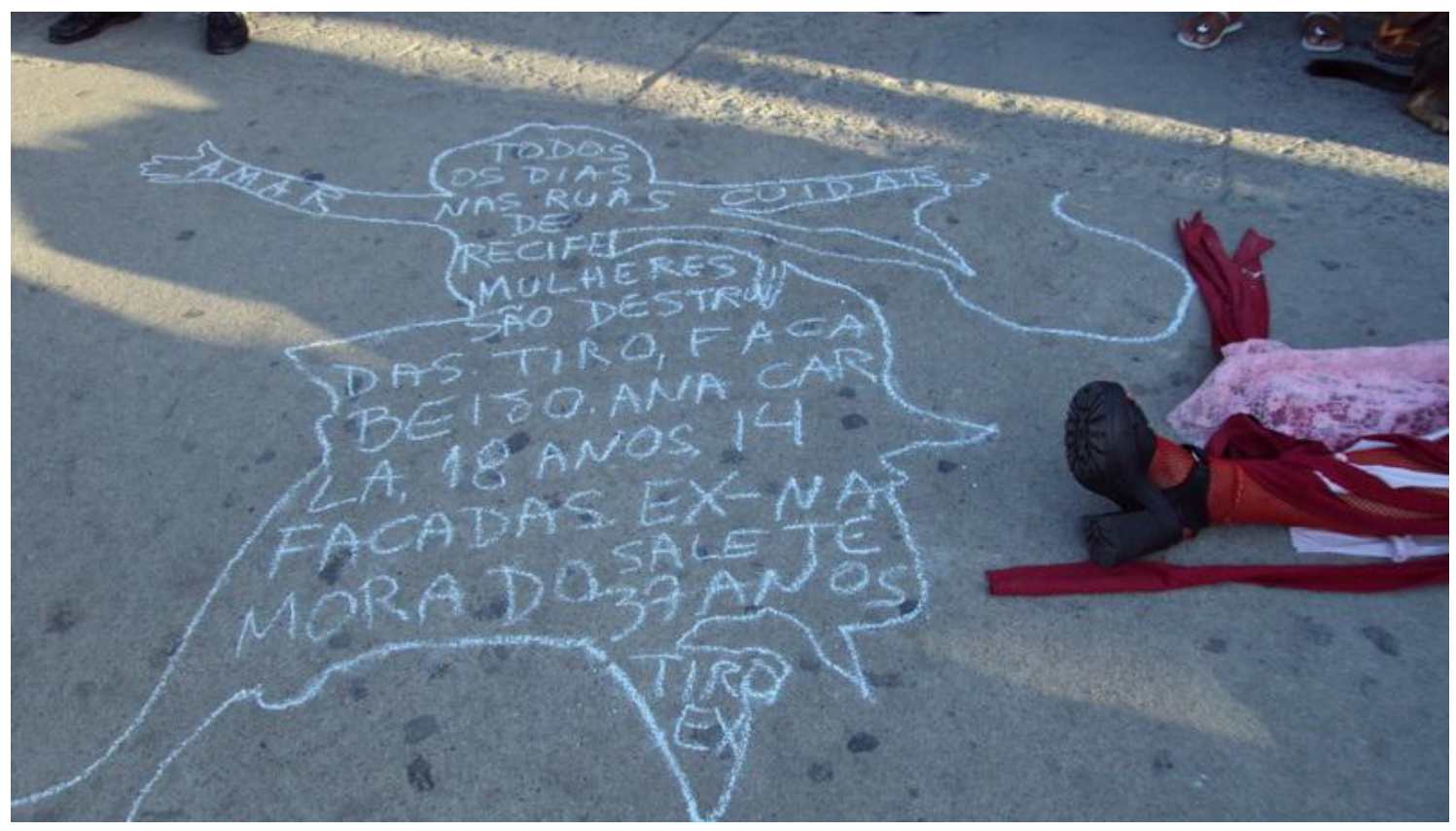

FIG. 12. XII Festival Recife do Teatro Nacional: Baby Dolls, uma exposição de bonecas. Foto de Janaína Melo.

Entendo essa escrita performada, produzida em processo, como fruto de uma dimensão coletiva e ligada intrinsecamente ao acontecimento, à ação concreta e as relações possíveis entre atuantes e transeuntes, espectadores e partícipes. Livre das determinações de um autor-deus, entregue ao fluxo dos passantes, a escritura se instaura em meio ao fluxo dos corpos leitores, se instala na fenda entre meu olhar/escuta que capta e o ato de desenhar as palavras no corpo giz no chão. O texto não pertence mais a mim. O texto é o corpo da atriz dialogando comigo, seus olhares, quando ela vê/interage com a menina de rosa e seu jovem pai: uma família. Quando estaciona sob o cartaz de "compromisso marcado" e tira fotos com homem que passa: casal. Quando avança sobre as reentrâncias/volumes das arquiteturas das cidades: monumento. O texto se instala no tapete tecido das imagens, páginas de revistas femininas. O texto objeto brinquedo de menina. O texto rosa. $\mathrm{O}$ texto bonecas em série. O texto escuta cruzamento desses corpos-vozes. Pois se a matéria do escritor é a palavra, aqui esta palavra está escrita no corpo. A palavra escrita no espaço da cidade e na duração da presença. A palavra performada no aqui e no agora. Assim a escrituratexto se produz, nas dobras do sentido. 


\section{Considerações Finais}

Ao longo desta tese busquei perceber, à luz dos conceitos de polifonia (Bakhtin) e escritura (Barthes), de que modo os processos de criação e pesquisa cênica centralizados em dinâmicas relacionais colaborativas podem inscrever, nas textualidades produzidas no interior desses mesmos processos, os rastros e marcas deixadas pelo embate entre as vozes criadoras e suas matérias significantes heterogêneas. Em razão disso, a tese teve como eixo a descrição e análise das processualidades dramatúrgicas ocorridas no seio dos processos de criação vivenciados por dois grupos teatrais - a Maldita e o Grupo Teatro Invertido, ambos a partir da experiência de participação no projeto Cena $3 \times 4$ - e também por um grupo de pesquisa teórica e prática sobre a cena contemporânea, o Obscena, a partir do desenvolvimento do projeto Às margens do feminino: texturas teatrais da beira.

Parti, inicialmente, de uma abordagem teórica dos conceitos de dramaturgia e drama, buscando perceber o deslocamento da noção de dramaturgia, concebida, a partir de Aristóteles, como poética do drama - e, nesse sentido, como obra literária para uma concepção brechtiana de dramaturgia, ou seja, pensada a partir das relações entre texto, cena e recepção da obra. Nesse sentido, parti da discussão do conceito de mímesis, em Aristóteles, para a análise do drama moderno, realizada por Szondi, visadas teóricas que privilegiam a perspectiva literária do drama. Em seguida, abordei a crítica levantada por Ramos - corroborada pelas reflexões de Heuvel sobre as relações entre drama e encenação - no que concerne ao pensamento evolutivo do paradigma dramático, manifestado não somente por Szondi, mas também por Lehmann, para, então, a partir do eixo central da análise de Szondi - a dissolução da forma dramática pelos conteúdos épicos e líricos - centrar a discussão do conceito de dramaturgia na perspectiva do teatro épico.

Para isso, abordei a reflexão de Sarrazac - centrada no pensamento brechtiano sobre o conceito de escrita rapsódica, no qual ele aproxima a escrita dramatúrgica contemporânea não somente do domínio do épico, mas também do conceito de polifonia e discute, a partir de Brecht, uma possível estética do descontínuo, na qual o texto do dramaturgo já não é pensado como estrutura arquitetural ou como um "belo 
animal" (Aristóteles), mas como tecido fragmentado e híbrido. A partir daí, abordei as discussões de Dort e Pavis sobre o conceito brechtiano de dramaturgia, concebida como um conjunto formal e ideológico centrado nas relações entre texto e cena. Desse modo, o conceito de dramaturgia passa a designar não apenas uma forma textual, mas também uma forma teatral e, nesse sentido, pode se configurar a partir de uma prática coletiva de encenação que visa provocar um determinado efeito sobre o espectador. Examinei, então, sob o viés histórico, a prática do dramaturgismo para, posteriormente, discuti-lo, rapidamente, no âmbito dos processos coletivos de criação.

Tendo a relação com o espectador como eixo, parti para a abordagem da noção de texto, na qual tracei um paralelo entre o pensamento de Artaud e Barba - para os quais a linguagem teatral é, antes de tudo, uma linguagem material e cênica - e os Estudos da Linguagem, no qual o teatro é visto como produção discursiva. Em especial, a partir das reflexões de Barthes sobre o teatro e sobre o conceito de escritura - que, oposto ao de literatura, concebe o texto como prática de inscrição - pude pensar o texto como uma textura cênica fruto de uma enunciação coletiva.

A partir daí, abordei as práticas compartilhadas de criação cênico-dramatúrgica, buscando discutir as distinções traçadas, no âmbito dos estudos contemporâneos sobre o processo colaborativo, entre este modo de criação e a criação coletiva. Para isso, examinei o pensamento de Antônio Araújo, Reinaldo Maia, Santiago García, Sílvia Fernandes e Rosyane Trotta, nos quais se discute, sobremaneira, a garantia de um espaço de proposição e da autonomia de cada especificidade artística como elemento definidor dos processos de criação colaborativa. Centrei, então, a questão no âmbito das experiências brasileiras de criação coletiva e fiz uma breve retomada, a partir de Baumgärtel, não só da situação da dramaturgia até os anos 80, mas também das alterações sofridas no campo da criação teatral brasileira como um todo, com a modificação do contexto social e político pós-ditadura. Com a discussão da encenação autoral, ressaltei a crise da produção dramatúrgica no Brasil e a necessidade de novas experimentações no campo do texto, para, então, abordar mais diretamente o trabalho do dramaturgo no âmbito do processo colaborativo.

Com essa finalidade, tracei um paralelo entre a função do dramaturgo e a função do encenador - ambas dotadas de uma perspectiva obscena em relação à criação, pois que, embora imersas no processo, são funções externas à cena - buscando 
perceber, a partir das reflexões de Antônio Araújo (2008), suas especificidades e dinâmicas inter-relacionais. Percebendo o processo colaborativo como um modo de produção polifônico, abordei, finalmente, o conceito de polifonia, buscando relacionálo às características formais da produção dramatúrgica originada no interior desse modo de criação.

Definidas as balizas teóricas, parti para a descrição e análise dos processos colaborativos vivenciados pela Maldita Companhia de Investigação Teatral, centrando, principalmente, na experiência de participação dentro do projeto Cena $3 \times 4$ e no processo de criação do espetáculo Casa das Misericórdias. Na minha abordagem da processualidade dramatúrgica ocorrida no âmbito dessa criação, trabalhei com os conceitos de polifonia e rapsódia, bem como com as relações traçadas por Rubens Rewald entre dramaturgia e a Teoria do Caos, buscando perceber de que modo os procedimentos de criação adotados, bem como a perspectiva teórica que deu sustento a eles, permitiu o surgimento de uma dramaturgia polifônica, manifestada nos vários traços da textura cênica criada, tais como a coralidade e o contraponto estilístico, além das simultaneidades de planos escriturais.

Em seguida, dando continuidade à análise dos processos vivenciados pelos grupos que participaram do projeto Cena $3 \times 4$, examinei o percurso colaborativo do Grupo Teatro Invertido, desde seu primeiro contato (anterior à experiência no projeto) com essa metodologia de criação, durante a montagem de Nossa Pequena Mahagonny, que, embora partisse de princípios colaborativos, configurou-se, mais explicitamente, como criação coletiva, não só porque partiu da transcriação teatral de um texto dramatúrgico já existente - Ascensão e Queda da Cidade de Mahagonny, de Bertolt Brecht - mas também porque todas as decisões estéticas couberam às negociações dos atores com a direção. Em seguida, abordei o processo ocorrido no âmbito do Cena 3x4, o qual deu origem ao espetáculo Lugar Cativo e ao desejo de continuidade, por parte dos integrantes do Teatro Invertido, da pesquisa de uma metodologia colaborativa como modo de criação. Daí, parti para a análise do processo de Medeiazonamorta, no qual a textura resultante guarda características processuais bem marcadas, como a relação com o espaço encontrado e as pulsões corporais que orientam a composição de ações das figuras que transitam em cena. 
Finalizando a análise dos processos do Teatro Invertido, parti para a discussão do trabalho desenvolvido no âmbito do projeto Ator Invertido, cinco sentidos para a construção da cena, no qual o grupo investigou, revezando-se seus integrantes em cada função, a criação cênico-dramatúrgica a partir de cada especificidade artística presente na tríade básica do processo colaborativo: atuação, direção e dramaturgia. Desse modo, os criadores buscavam a construção de uma dramaturgia autoral, que refletisse a identidade do grupo. Em minha análise, busco perceber de que modo as relações criativas ocorridas durante o processo, embora apontassem para uma estrutura textual mais fragmentada e perpassada por uma dinâmica polifônica, puderam, em decorrência de uma visão canônica da dramaturgia, resultar em uma textualidade homogênea.

Por fim, abordei o percurso de investigação e criação ocorrido no âmbito do trabalho de pesquisa desenvolvido pelo Obscena, agrupamento independente de pesquisa cênica. Após diferenciar a prática dos coletivos contemporâneos de artes cênicas da prática dos grupos de teatro, discuti os modos de funcionamento e organização do agrupamento, a partir do desenvolvimento do projeto Às margens do feminino, texturas teatrais da beira. É perceptível que, no âmbito do trabalho desenvolvido pelo Obscena, a conjugação de pesquisas teóricas e práticas, individuais e compartilhadas, tem permitido a criação de uma rede de diálogos e trocas que gera não somente experimentos artísticos que desestabilizam a noção de criação cênica, mas também pensamento e reflexão teórica. Assim, a pesquisa realizada pelo agrupamento coloca, para mim, uma gama de questões, muitas das quais estão ainda por responder.

Nesse sentido, percebo que a abordagem realizada, no último capítulo desta tese, sobre a investigação que vem sendo desenvolvida pelo agrupamento, é a primeira tentativa de delimitação de um work in process, de um pensamento e de uma criação em processo nos quais vislumbro, para o meu trabalho de escritura, novos caminhos de pesquisa, pois ele localiza o trabalho de criação dramatúrgica em outro campo, não mais estritamente teatral, mas performativo. Não mais estritamente dentro de um processo de criação colaborativa, pois não visa à produção de uma obra em comum, mas à construção de uma rede de pensamento em ação. Nesse sentido, ele aponta para uma nova perspectiva teórica, na qual o conceito de dramaturgia polifônica parece não dar conta da investigação textual, tornando necessário pensar a criação em relação 
estreita com a potência dramatúrgica da cidade, como ressalta André Carreira (2009), ao falar do teatro de invasão.

Ao ultrapassar os limites não só das formações grupais, mas também do processo colaborativo e do próprio teatro, a investigação realizada, em rede colaborativa, pelo Obscena, me possibilitou pensar a experimentação dramatúrgica e textual para além do campo puramente ficcional e instaurar um jogo de escritura em relação tanto aos fluxos cotidianos da cidade como aos fluxos performativos dos outros pesquisadores. Na tese, busquei desenhar, então, a partir das noções de escritura e de performatividade, o conceito de escrita performada, tentando dar conta da produção textual investigada por mim durante o processo de criação de duas intervenções urbanas, Mulheres Mortas e Baby Dolls, uma exposição de bonecas. Com essa finalidade, parti da análise dos percursos de criação e das questões teóricas que os perpassavam para pensar o papel do dramaturgo, ou melhor, do trabalho de escritura, no fluxo da ação performativa que ocorre no corpo da cidade e por meio das dinâmicas relacionais com os transeuntes. O conceito de escrita performada, do mesmo modo que a criação que deu origem a ele, é um conceito em processo de formação e, dessa perspectiva, posso afirmar que o capítulo do Obscena finaliza uma etapa de pesquisa e, paradoxalmente, lança pontes para investigações futuras. 


\section{REFERÊNCIAS BIBLIOGRÁFICAS}

\section{LIVROS}

ARISTÓTELES. Poética. Tradução de Eudoro de Souza. São Paulo: Ars Poética, 1992.

ARTAUD, Antonin. Linguagem e vida. São Paulo: Perspectiva, 2004.

. O teatro e seu duplo. São Paulo: Martins Fontes, 1999.

BACHELARD, Gaston. A poética do espaço. São Paulo: Martins Fontes, 2002.

BAKHTIN, Mikhail. Problemas da poética de Dostoiévski. Rio de Janeiro: Forense Universitária, 2008.

Questões de literatura e de estética: a teoria do romance. São Paulo: Annablume/HUCITEC, 2002.

BARBA, Eugênio e SAVARESE, Nicola. A arte secreta do ator: dicionário de antropologia teatral. São Paulo, Campinas: Hucitec, 1995.

BARTHES, Roland. O prazer do texto. Tradução J. Guinsburg. São Paulo: Perspectiva, 2006.

Fontes, 2004.

O rumor da língua. Tradução Ivone Castilho Beneditti. São Paulo: Martins

BORIE, Monique; ROUGEMONT, Martine de; SCHERER, Jacques. Estética Teatral, textos de Platão a Brecht. Lisboa, Fundação Calouste Gulbenkian, 1996.

BORNHEIM, Gerd. Brecht: a estética do teatro. Rio de Janeiro: Graal, 1992.

BRANDÃO, Carlos A. Leite. Grupo Galpão: Diário de Montagem. Belo Horizonte: UFMG, 2003.

BRECHT, Bertolt. Estudos sobre o teatro. Rio de Janeiro: Nova Fronteira, 2005.

CAETANO, Nina et alii (org.). Cena Invertida: dramaturgias em processo. Belo Horizonte: Edições CPMT, 2010.

CARLSON, Marvin. Teorias do Teatro: estudo histórico-crítico, dos gregos à atualidade. São Paulo: Editora UNESP, 1997.

CERTEAU, Michel de. A Invenção do cotidiano: artes de fazer. Petrópolis: Vozes, 1994. 
COHEN, Renato. Performance como linguagem. São Paulo: Perspectiva, 2004a.

Work in progress na cena contemporânea: criação, encenação e recepção. São Paulo: Perspectiva, 2004b.

COMPAGNON, Antoine. O demônio da teoria. Belo Horizonte: Editora UFMG, 2001.

CARREIRA, André. Teatro da invasão: redefinindo a ordem da cidade IN: LIMA, Evelyn F. Werneck. Espaço e Teatro: do edifício teatral à cidade como palco. Rio de Janeiro: 7 letras, 2008.

CRAIG, Edward Gordon. De l'Art du Théâtre. Paris : Éditions Lieutier, 1942.

DELEUZE, Gilles, GUATTARI, Félix. Mil Platôs - Capitalismo e Esquizofrenia. São Paulo: Editora 34, 1995.

DeSGrangeS, Flávio. Pedagogia do Teatro: Provocação e Dialogismo. São Paulo: Hucitec, 2006.

. A pedagogia do espectador. São Paulo: Hucitec, 2003.

DERRIDA, Jacques. A escritura e a diferença. São Paulo: Perspectiva, 2005.

DIAZ, Henrique; OLINTO, Marcelo; CORDEIRO, Fábio (org.). Na Cia. dos Atores. Rio de Janeiro: Aeroplano, 2006.

DORT, Bernard. O teatro e sua realidade. São Paulo: Perspectiva, 2010.

. La Représentation Émancipée. Arles: Actes Sud, 1988.

ECO, Umberto. Obra Aberta. São Paulo: Editora Perspectiva, 1991.

ESCOLANO, Agustin \& FRAGO, Antonio Viñao. Currículo, espaço e subjetividade: a arquitetura como programa. Trad. Alfredo Veiga Neto. Rio de Janeiro: DP\&A, 1998.

FOUCAULT, Michel. A ordem do discurso. São Paulo: Edições Loyola, 1996.

FERNANDES, Sílvia. Teatralidades Contemporâneas. São Paulo: Editora Perspectiva, 2010.

. Grupos teatrais: anos 7o. Campinas: Editora da UNICAMP, 2000.

FOUCAULT, Michel. O que é um autor? IN: Ditos e Escritos, III. Rio de Janeiro: Forense Universitária, 2006.

GARCÍA, Santiago. Teoria e Prática do Teatro. São Paulo: Editora Hucitec, 1988. 
GLUSBERG, Jorge. A Arte da Performance. São Paulo: Editora Perspectiva, 1987.

GROTÓVSKI, Jerzy. Em busca de um teatro pobre. Rio de Janeiro: Civilização Brasileira, 1992.

GUATTARI, Felix. Caosmose: um novo paradigma estético. São Paulo: Editora 34, 1992.

GUINSBURG, Jacó; FARIA, João Roberto; LIMA, Mariângela Alves de. Dicionário do Teatro Brasileiro: temas, formas e conceitos. São Paulo: Editora Perspectiva e SESC SP, 2006.

HEUVEL, Michael Vanden. Performing Drama/Dramatizing Performance: alternative theater and the dramatic text. Michigan: University of Michigan Press, 1991.

KRISTEVA, Julia. Introdução à Semanálise. São Paulo: Perspectiva, 2005.

LEHMANN, Hans-Thies. Teatro pós-dramático. São Paulo: Cosac Naify, 2007.

MARTINS, Marcos Bulhões. Encenação em jogo: experimento de aprendizagem e criação do teatro. São Paulo: Hucitec, 2004.

MARINIS, Marco de. In Cerca dell'Attore. Roma: Bulzoni Editore, 2000.

PAVIS, Patrice. Dicionário de Teatro. São Paulo: Perspectiva, 1999.

PUPO, Maria Lúcia de Souza Barros. Entre o Mediterrâneo e o Atlântico: uma aventura teatral. São Paulo: Perspectiva, 2005.

REWALD, Rubens Arnaldo. Caos/Dramaturgia. São Paulo: Perspectiva, 2005.

ROSENFELD, Anatol. O teatro épico. São Paulo: Perspectiva, 1990.

ROUBINE, Jean-Jacques. A linguagem da encenação teatral. Rio de Janeiro: Jorge Zahar Ed., 1998.

RYNGAERT, Jean-Pierre. Ler o teatro contemporâneo. São Paulo: Martins Fontes, 1998.

Le personnage théâtral contemporain : décomposition, recomposition. Paris : Éditions Théâtrales, 2006.

SALLES, Cecília Almeida. Redes da Criação: construção da obra de arte. Vinhedo: Editora Horizonte, 2006. 
. Gesto Inacabado: processo de criação artística. São Paulo: Annablume, 2001.

. Crítica Genética: uma (nova) introdução. São Paulo: Educ, 2000.

SANTOS, Milton. A Natureza do Espaço. São Paulo, Editora EDUSP, 2002.

SARRAZAC, Jean-Pierre. O Futuro do Drama. Porto: Campo das Letras, 2002. . Lexique du drame modern et contemporain. Belval: Les éditions Circé, 2005

SCHECHNER, Richard. Performance Studies: an Introduction. New York \& London: Routledge, 2006.

SZONDI, Peter. Teoria do drama moderno (1880-1950). Trad. de L. S. Repa. São Paulo: Cosac \& Naify, 2001.

TODOROV, Tzvetan. Poética da prosa. São Paulo: Martins Fontes, 2003.

UBERSFELD, Anne. Les termes clés de l'analyse du théâtre. Paris : Seuil, 1996. . Lire lê théâtre II : l'école du spectateur. Paris : Belin, 1996.

WILLEMART, Philippe. Universo da Criação Literária. São Paulo: EDUSP, 1993.

ZOURABICHVILI, François. O Vocabulário de Deleuze. Rio de Janeiro: Relume Dumará, 2004.

ZULAR, Roberto (org.). Criação em Processo: ensaios de crítica genética. São Paulo: Iluminuras, 2002.

TESES, DISSERTAÇÕES E MONOGRAFIAS

ALMEIDA, Márcio Aurélio Pires de. O Encenador como Dramaturgo: a escrita poética do espetáculo. 1995. Tese (Doutorado em Artes Cênicas) - Escola de Comunicações e Artes, Universidade de São Paulo.

ANDRADE, Wellington Wagner. O Livro de Jó, de Luís Alberto de Abreu: mito e invenção dramática. 200o. Dissertação (Mestrado em Literatura Brasileira) Faculdade de Filosofia, Letras e Ciências Humanas, Universidade de São Paulo.

RAMIREZ, Merle Ivone Barriga. As Ações de Artur Barrio: um modelo não representacional para o ator contemporâneo. 2006. Dissertação (Mestrado em Artes Cênicas) - Escola de Comunicações e Artes, Universidade de São Paulo. 
BRITO, Rubens José Souza. Dos Peões ao Rei: O Teatro Épico-Dramático de Luís Alberto de Abreu. 1999. Tese (Doutorado em Artes Cênicas) - Escola de Comunicações e Artes, Universidade de São Paulo.

DA COSTA FILHO, José. Teatro brasileiro contemporâneo: um estudo da escritura cênico-dramatúrgica atual. 2003. Tese (Doutorado em Literatura Comparada) - Instituto de Letras, Universidade do Estado do Rio de Janeiro.

FIGUEIREDO, Ricardo Carvalho de. A dimensão coletiva na criação: o processo colaborativo no Galpão Cine Horto. 2007. Dissertação (Mestrado em Artes) Escola de Belas Artes, Universidade Federal de Minas Gerais.

FISCHER, Stela Regina. Processo Colaborativo: experiências de companhias teatrais brasileiras nos anos 90. 2003. Dissertação (Mestrado em Artes) Instituto de Artes, Universidade Estadual de Campinas.

GASPERI, Marcelo Eduardo Rocco. A aproximação entre a cena e o espectador transeunte na sociedade espetacularizada: "Às margens do feminino" agrupamento Obscena. 2010. Dissertação (Mestrado em Artes) - Escola de Belas Artes, Universidade Federal de Minas Gerais.

MAIA, Rita de Cássia Pinho. $\mathbf{O}$ ator em questão: um foco na função do ator no Processo Colaborativo do Grupo Teatro Invertido. Dissertação de Mestrado. Belo Horizonte: UFMG, 2010.

MALETTA, Ernani de Castro. A formação do ator para uma atuação polifônica: princípios e práticas. 2005. Tese (Doutorado em Educação) - Faculdade de Educação, Universidade Federal de Minas Gerais.

NICOLETE ABREU, Adélia Maria. Da Cena ao Texto: dramaturgia em processo colaborativo. 2005. Dissertação (Mestrado em Artes Cênicas) - Escola de Comunicações e Artes, Universidade de São Paulo.

O Texto Teatral: reflexões sobre alguns processos de criação da dramaturgia contemporânea. 2002. Monografia (Especialização em Educação) Centro Universitário de Santo André, 2002.

OLIVEIRA. Rogério Santos de. O Espaço-Tempo da Vertigem: grupo Teatro da Vertigem. 2005. Dissertação (Mestrado em Teatro) - Centro de Letras e Artes da UNIRIO, Universidade Federal do Estado do Rio de Janeiro.

QUADROS, Magali Helena de. Buscando compreender a função de dramaturgista. Dissertação (Mestrado em Teatro) - Programa de Pós-Graduação em Teatro da Universidade do Estado de Santa Catarina, 2007.

REWALD, RUBENS. Autor-espectador. 2004. Tese (Doutorado em Ciências da Comunicação) - Escola de Comunicação e Artes, Universidade de São Paulo. 
RINALDI, Miriam. O Ator do Teatro da Vertigem: o processo de criação de Apocalipse 1,11. 2005. Dissertação (Mestrado em Artes Cênicas) - Escola de Comunicações e Artes, Universidade de São Paulo.

SANTOS, Clóvis Domingos dos. A Cena Invertida e a Cena Expandida: projetos de aprendizagem e formação colaborativas para o trabalho do ator. 2010. Dissertação (Mestrado em Artes) - Escola de Belas Artes, Universidade Federal de Minas Gerais.

SILVA, Ana Maria Rebouças Rocha. Poética Cênica na Dramaturgia Brasileira Contemporânea. 2001. Dissertação (Mestrado em Artes Cênicas) - Escola de Comunicações e Artes, Universidade de São Paulo.

SILVA, Antônio Carlos de Araújo. A encenação no coletivo: desterritorializações da função do diretor no processo colaborativo. 2008. Tese (Doutorado em Artes Cênicas) - Escola de Comunicação e Artes, Universidade de São Paulo.

A Gênese da Vertigem: o processo de criação de O Paraíso Perdido. 2002. Dissertação (Mestrado em Artes Cênicas) - Escola de Comunicação e Artes, Universidade de São Paulo.

TROTTA, Rosyane. A autoria coletiva no processo de criação teatral. 2008. Tese (Doutorado em Teatro) - Centro de Letras e Artes da UNIRIO, Universidade Federal do Estado do Rio de Janeiro.

\section{REVISTAS E ARTIGOS}

ABREU, Luiz Alberto de. A restauração da narrativa. IN: O PERCEVEJO, revista do Programa de Pós-Graduação em Teatro da UNIRIO. Rio de Janeiro: Editora da UNIRIO, n. 9, 1998.

- Processo colaborativo: relato e reflexões sobre uma experiência de criação. CADERNOS DA ELT, Santo André, v. 1, n. o, mar. 2003, pp. 33-41.

BARRIO, Artur. 4 DIAS 4 NOITES IN: CANONGIA, Lígia. Artur Barrio. Rio de Janeiro: Modo, 2002, p. 203.

. Lama/Carne Esgoto IN: CANONGIA, Lígia. Artur Barrio. Rio de Janeiro: Modo, 2002, p. 203.

BARTHES, Roland. Le théâtre de Baudelaire IN: Écrits sur le théâtre. Paris: Seuil, 2002, pp. 122-129. 
BAUMGÄRTEL, Stephan A. Em busca de uma teatralidade textual performativa na sombra da globalização: reflexões sobre a situação da dramaturgia brasileira no fim dos anos 80 . S/R (artigo inédito).

BENJAMIN, Walter. O autor como produtor IN: Magia e técnica, arte e política: ensaios sobre literatura e história da cultura. Rio de Janeiro: Brasiliense, 1986.

BRNA, Paul. Modelos de colaboração. Trad. Álvaro de Azevedo Diaz. Disponível em: http://www.inf.ufsc.br/sbc-ie/revista/nr3/Brnao3.htm

BUENAVENTURA, Enrique. Dramaturgia del actor. Disponível em: www.teatrodelpueblo.org.ar

CANONGIA, Lígia. Barrio Dinamite IN: CANONGIA, Lígia. Artur Barrio. Rio de Janeiro: Modo, 2002, p. 203.

CARREIRA, André \& OLIVEIRA, Valéria Maria de. Teatro de grupo: modelo de organização e geração de poéticas. IN: O TEATRO TRANSCENDE. Blumenau: FURB, ano 12, n. 11, 2003.

CARREIRA, André. Ambiente, fluxo e dramaturgias da cidade: materiais do Teatro de Invasão IN: O PERCEVEJO on line, periódico do Programa de PósGraduação em Artes Cênicas da UNIRIO, vol. 1, fascículo 1, janeiro-junho/20o9.

. Teatro de Grupo: diversidade e renovação do teatro no Brasil IN: SUBTEXTO, Revista de Teatro do Galpão Cine Horto. Belo Horizonte: Edições CPMT, ano IV, n. 4, nov 2007, pp. 8-11.

Os Não-Lugares: teatro de rua como resistência. IN: O TEATRO TRANSCENDE. Blumenau: FURB, ano 13, n. 1, $2004 \mathrm{a}$.

APOCALIPSE 1,11: risco como meio para explorar a teatralidade. IN: Mediações performáticas latino-americanas II. Belo Horizonte: Faculdade de Letras da UFMG, 2004b.

Performance teatral e risco físico: construção de vínculos e exploração de margens IN: CARREIRA, André et al. (org.). Mediações performáticas latino-americanas. Belo Horizonte: FALE/UFMG, 2003, p. 21.

CHARAUDEAU, Patrick. Une analyse sémiolinguistique du discours. IN: LANGAGES. Paris: Larousse, n. 117, 1995.

COSTA, Marcelo Henrique e PENIDO, Bete. Caixa Postal 1500 IN: Cadernos de Dramaturgia do Galpão Cine Horto: oficinão. Belo Horizonte: Argvmentvm, 2009, vol. 1, p. 33. 
DORT, Bernard. L'état d'esprit dramaturgique IN: Revista Thêatre/Public: Dramaturgie. Gennevilliers, no 67, jan-fev 1986, pp. 8-12.

DESGRANGES, Flávio. Teatralidade tátil: alterações no ato do espectador IN: SALA PRETA, revista do Programa de Pós-Graduação em Artes Cênicas. São Paulo: ECA/USP, n. 8, 2008, pp. 11-19.

FÉRAL, Josette. Por uma poética da performatividade: o teatro performativo IN: SALA PRETA, revista do Programa de Pós-Graduação em Artes Cênicas. São Paulo: ECA/USP, n. 8, 2008, pp. 197-210.

Performance et théâtralité: le sujet démystifié. Texto publicado originalmente em inglês, IN: Modern Drama, vol. 25, 1982, pp. 170-181.

. La performance ou le refus du théâtre IN: Protée, vol. 17, 1989, pp. 6o-

66.

. Que reste-t-il de la performance? Autopsie d'une fonction; la naissance d'un genre. Texto publicado originalmente em ingles, IN: Discourse, Journal for theoretical studies in media and culture Performance Issue(s): Happenings, Body, Spectacle, Virtual Reality, 1992, pp. 140-161.

FERNANDES, Sílvia. Teatros pós-dramáticos IN: GUINSBURG, J. \& FERNANDES, S. O Pós-Dramático, um conceito operativo? São Paulo: Editora Perspectiva, 2010, pp. 11-30.

. O lugar da Vertigem IN: ARAÚJO et alii. Trilogia bíblica. São Paulo: Publifolha, 2002, pp. 35-40.

GALPÃO CINE HORTO. Grupos de Teatro no Brasil: realidade e diversidade IN: SUBTEXTO, Revista de Teatro do Galpão Cine Horto. Belo Horizonte: Edições CPMT, ano IV, n. 4, nov 2007.

GARROCHO, Luiz Carlos. Medeiazonamorta: dos corpos, dos planos e do todo aberto IN: Cena Invertida: dramaturgias em processo. Belo Horizonte: Edições CPMT, 2010, pp. 56-73.

A impregnância do sentido no teatro: Cara Preta Disponível em: www.luizcarlosgarrocho.redezero.org.

GRUPO TEATRO INVERTIDO. Por um olhar inverso IN: Cena Invertida: dramaturgias em processo. Belo Horizonte: Edições CPMT, 2010, pp 6-19.

LEAL, Juliana Helena Gomes. Escrita performática latino-americana contemporânea IN: Anais do Congresso Internacional da ABRALIC: Tessituras, interações, convergências. São Paulo: USP, 13 a 17 de julho de 2008. 
MAIA, Reinaldo. Duas ou três coisinhas sobre o processo colaborativo. S/R (artigo não publicado).

MENCARELLI, Fernando Antônio. Dramaturgias em processo: a cena pelo avesso IN: Cena Invertida: dramaturgias em processo. Belo Horizonte: Edições CPMT, 2010, pp 12-25.

PELÚCIO, Chico. O projeto Oficinão do Galpão Cine Horto IN: Cadernos de Dramaturgia do Galpão Cine Horto: oficinão. Belo Horizonte: Argvmentvm, 2009, vol. 1, p. 8 .

PHELAN, Peggy. Performative writing IN: Mourning Sex. 1997: pp.11-12.

PINTO, Davi Oliveira de. Nossa Pequena Mahagonny: aspectos processuais de uma dramaturgia colaborativa IN: Cena Invertida: Dramaturgias em Processo. Belo Horizonte: Edições CPMT, 2010, pp 26-39.

RAMOS, Luiz Fernando. Pós-dramático ou poética da cena? IN: GUINSBURG, J. \& FERNANDES, S. O Pós-Dramático: um conceito operativo? São Paulo: Perspectiva, 2010, pp. 59-70.

- Dramaturgia da cena ou materialidade do espetáculo? IN: Revista do Festival Internacional de São José do Rio Preto. 9-19 julho 2008, p. 89.

. Gracías, Portugal. (artigo S/D).

RAOUL-DAVIS, Michèle. Profession Dramaturge IN: Revista Thêatre/Public: Dramaturgie. Gennevilliers, no 67, jan-fev 1986, pp. 4-6.

RAVETTI, Graciela. Performances escritas: o diáfano e o opaco da experiência IN: HILDEBRANDO, Antônio et alii (org.). O corpo em performance: imagem, texto, palavra. Belo Horizonte, NELAP/FALE/UFMG, 2003, pp. 31-61.

SENE, Patrícia. Agrupamento de Ações: Aceita um café? Artigo inédito. Belo Horizonte, 2008.

SILVA, Heloisa Marina da e BAUMGÄRTEL, Stephan Arnauf. Possíveis processos da escrita teatral contemporânea IN: Revista DAPesquisa. Vol. 3, no 2, ago/2008 a jul/2009.

TAYLOR, Diana. Encenando a memória social: Yuyachkani IN: RAVETTI, G. \& ARBEX, M. (org.). Performance, exílio, fronteiras: errâncias territoriais e textuais. Belo Horizonte: FALE/UFMG, 2002, pp. 13-45.

TROTTA, Rosyane. Grupos de Teatro no Brasil: convergências e divergências IN: SUBTEXTO, Revista de Teatro do Galpão Cine Horto. Belo Horizonte: Edições CPMT, ano V, n. 5, dez 2008, pp. 31-36. 
. Autoralidade, grupo e encenação. IN: SALA PRETA, revista do Programa de Pós-Graduação em Artes Cênicas. São Paulo: ECA/USP, n. 6, 20o6, pp. 31-36.

VELOSO, Verônica Gonçalves. Grupo ou coletivo: uma questão de tempo IN: Anais do V Congresso da ABRACE: criação e reflexão crítica, Belo Horizonte, 28 a 31 de outubro de 2008.

\section{TEXTOS TEATRAIS}

ANDRADE, Letícia. Cara Preta. S/D: Texto inédito.

. Medeiazonamorta IN: Cena Invertida: dramaturgias em processo. Belo Horizonte: Edições CPMT, 2010, pp. 108-157.

AUTORIA COLETIVA. Caixa Postal 1.50o IN: Cadernos de Dramaturgia do Galpão Cine Horto: oficinão. Belo Horizonte: Argvmentvm, 2009, vol. 1, pp. 80-81.

CAETANO, Nina. Casa das Misericórdias. S/D: Texto inédito.

SANTOS, Pollyana Costa. Lugar Cativo IN: Cena Invertida: dramaturgias em processo. Belo Horizonte: Edições CPMT, 2010, pp. 82-83.

\section{WEBSITES}

www.cialunalunera.blogspot.com

www.cia-maldita.blogspot.com

www.comjuntovazio.wordpress.com

www.davipantuzza.blogspot.com

www.galpaocinehorto.com.br

www.n3ps-pesquisaperformance.blogspot.com

www.obscenica.ning.com

www.obscenica.blogspot.com

www.piabrasil.wordpress.com

www.poro.redezero.org 
ANEXOS 
Anexo A - Dramaturgia de Casa das Misericórdias

\title{
m a I d i t a
}

cia. de investigação teatral

apresenta:

\section{casa das misericórdias}

\author{
texto de autoria coletiva \\ dramaturgia: nina caetano
}

autores:
amaury ines lenine lissandra nina gicardo
borges linke martins guimarães caetano garcia


Prólogo

Um homem abre a porta, recebendo os visitantes. Arquitetura do abandono. Lugar híbrido, cheiro de hospital. Corredor. Pátio. A fachada de uma velha casa. Bancos compridos espalhados pelo lugar: sala de espera. Bar. A luz clara deixa ver as paredes cobertas por escritos que se sobrepõem. $O$ homem adverte que as bolsas devem ficar debaixo dos bancos. Enquanto os visitantes se instalam, uma voz de mulher, no interior da casa, começa a tecer uma ladainha (canção do hospício de Barbacena).

VOZ - Santa Maria, tenha compaixão

Tirai nós todas dessa prisão

Estamos todas desesperadas

Lavando o pátio de pé no chão

Lá vem a bóia do pessoal

Arroz cru e feijão sem sal

E mais atrás vem o macarrão

Parece cola de colar balão

E mais atrás vem a sobremesa

Banana podre em cima da mesa

E mais atrás vem os funcionários

Que são os puto mais ordinário...

O homem adentra a casa. Ouve-se uma forte batida, vinda do interior. A luz se apaga. Blackout. Outras cinco batidas - como portas fechadas à força entremeiam o final da canção. 


\section{Cena o1}

LAURINDA - Manicômio Judiciário Feminino. No pavilhão onze, no cubículo um, o dia amanhece e Laurinda vaga sozinha com sua multidão de lembranças. Ela passou a noite acordada, seus olhos, dois imensos faróis numa noite escura. Sangue. Dor. Na sua frente, uma parede. Laurinda escreve. A memória se materializa para dar vazão ao turbilhão que a sufoca. Há quanto tempo "vive” nesse cu de deus? Nem se lembra mais. Laurinda fita as paredes, procurando datas. Uma página inteira de sua vida. Um fio que se desfia enquanto ela percorre labirintos que criou para sobreviver. Há quanto tempo vive nesse buraco imundo, fedorento e frio? Você sabe? Sente um aperto no coração. Não é possível que eu me acostume. Nunca, nunca!

Em um quartinho à direita, no interior da casa, no rádio soa a canção Jesus Cristo (de Roberto Carlos). Barulho do rádio saindo de sintonia. O som aumenta de volume e depois desaparece. A sombra do homem se projeta pela janela.

GUARDA - Segunda-feira. No rádio-relógio, Jesus Cristo anuncia: são seis horas da manhã. João de Deus é guarda do Manicômio Judiciário Feminino. Ele já dorme de uniforme, é bem mais prático. O guarda mora num quartinho da pensão Santa Fé. Descendo a escada, fica o banheiro. João de Deus lava a cara, faz a barba. Cumprimenta seu Moisés, o dono da pensão. Depois, pega a chave e sai. (sua sombra passa) É cedo, mas já tem gente na rua. Bom dia dona Preta! Bom dia, seu Eustáquio...

\section{Balcão do bar. O Guarda coloca um radinho de pilha sobre a bancada.}

GUARDA - O guarda toma café logo ali em frente, no bar do Salvador. Lá, João de Deus encontra sempre as mesmas pessoas. Bom dia... Salvador já sabe... (serve uma pinga) é só ele entrar que já oferece um “pingado”. Aceita um pingado aí? O café do Salvador é bom, é encorpado... (toma um gole) Eta cafezinho bom! Desde que foi empregado que João de Deus vai ali pra juntar forças. 
Sete e cinco da manhã. Ele pega serviço às sete. Mas João de Deus sempre chega atrasado. Ele eu sou funcionário público, eu tenho esse direito: só tenho o dia cortado se atrasar mais de 15 minutos. Então o Guarda bate o cartão às 7 e 15 em ponto. Eu tenho esse direito!

Dez anos sem beber nem fumar. Até pegar o pavilhão onze. O pavilhão de Laurinda.

LAURINDA - Se alguém perguntar por mim, não pertenço a ninguém!

GUARDA - Uma doida. Uma perdida. Uma assassina de criança.

LAURINDA - Laurinda, a Linda, devia agradecer todos os dias pela estadia nesse lugar de merda!

GUARDA - Sete e dez... É hora de ir pro serviço. Até mais ver. João de Deus sai do bar e vira a esquina. Para em frente ao manicômio: é preciso tomar coragem. João de Deus observa os muro. E antes de atravessar os portão do inferno, ele pega rezando um pai nosso que estais no céu,

santificado seja o vosso nome, venha No interior do cubículo, soa a voz

a nós o vosso reino, seja feita a vossa da mulher (rezas simultâneas). vontade, assim na terra como no céu. LAURINDA - Salve, Laurinda, cheia de O pão nosso de cada dia nos daí hoje, racha. Beleza, rachadura, esperança nossa Perdoai as nossas ofensas, assim Venha a nós que recorremos a vós assim como nós perdoamos a quem nos Degenerados Pervertidos Amoralizados tem ofendido Só vos difama, proclama, no mais

Não nos deixeis cair em tentação $\quad$ profundo do espírito... O prazer é a mas solução, o prazer é a salvação! livrai-nos do mal. Amém Gozem, amem amem amem

GUARDA - O Guarda atravessa o corredor até se deparar com o pavilhão onze. Aqui, antigamente, era cheio de doido. Agora tá tudo vazio, só tem Laurinda. O médico aparece uma vez na vida, outra na morte. E há muito que o guarda faz as vez de 
enfermeiro. É ele eu que dou comida, dou remédio, dou tudo: eu é que cuido de Laurinda. E João de Deus vai levando... mas é que ele tem uma missão:

LAURINDA - Mais uma “Semana Santa”...

GUARDA - Salvar a alma dessa mulher. (Laurinda irrompe pela porta).

LAURINDA - Sempre que ela sangra é assim: o guarda resolve purificá-la!

GUARDA - O guarda entra na sua salinha e liga o rádio na estação cristã.

LAURINDA - Laurinda sofre porque o homem que gosta de reza não gosta dela como devia. Gosta de reza, não gosta dela... (o guarda aumenta o volume do rádio até cobrir a voz de Laurinda...) gosta de reza... Gosta de reza... Reza! (...depois desliga.) 


\section{Cena o2}

GUARDA - Terça-feira, sete e meia da manhã. É hora do café da manhã de Laurinda. O Guarda se dirige pro Cubículo Um. E pelo caminho vai acendendo a luz do corredor... (Santo anjo do Senhor, meu Divino protetor... me guarda, me rege e me guia. Amém.) Merda, essa lâmpada tá queimada! Zero Hora... (Zero Hora era o guarda da noite) ainda não trocou a lâmpada. Vai acabar sobrando pro João de Deus... O Guarda para em frente à cela de Laurinda.

LAURINDA - O cheiro de loção pós-barba.

GUARDA - Laurinda tá de jejum desde ontem: é Semana Santa. Bom dia, Laurinda! Que o Senhor esteja convosco!

LAURINDA - Me dá meu pão!

GUARDA - Primeiro, bom dia... Que o Senhor esteja convosco, Laurinda!

LAURINDA - O Senhor é convosco! Enrosco em vosco.

GUARDA - O Guarda resolve avisar a Laurinda que hoje vai ser diferente. É pra rezar direito, Laurinda. É Semana Santa. Se você rezar direito, minha irmã, eu te prometo com fé em Deus, que eu te dispenso do jejum. O jejum é porque Laurinda precisa se preparar pra sexta-feira da paixão. Nem o remédio o guarda deu, que é para ela ficar pura.

LAURINDA - Me dá meu pão, Guarda Belo.

GUARDA - Pão, Laurinda. Tá aqui, fresquinho pra você comer. Se você aceitar a palavra do Divino, a gente acaba com o jejum. Um pão fresquinho. Tá aqui. Eu trouxe pra você. Reza! 
LAURINDA - O tom bom e arrogante da voz do Guarda irrita Laurinda.

GUARDA - Jesus, em seu imenso amor, morreu para nos salvar, morreu para te salvar!... Ele está no meio de nós.

LAURINDA - Ele está dentro de nós! Laurinda podia fazer isso: parar de provocar o Guarda. Ele está aqui, bem dentro de mim, Guarda Belo!

GUARDA - Laurinda! Meu nome não é Belo! É João, João de Deus! (pausa. O guarda tenta se conter) Laurinda, de uma feita, estava Jesus com seus apóstolos orando num certo lugar; quando terminou, um deles lhe chegou e pediu: Senhor, ensina-nos a orar assim como João ensinou aos seus discípulos... Então eu ele os ensinou dizendo...

(simultâneas)

LAURINDA - Grande Pau que estais no céu! Venha a nós com vossa porra!

Penetrai todas as mulheres benditas que eu tiver escrito $o$ nome!
GUARDA - Pai Nosso que estais no céu, santificado seja vosso nome...

O Guarda bem sabe que Laurinda provoca! É o seu exercício diário. Todos os dias, o Guarda faz um esforço sobre humano para não invadir a cela dessa puta, louca, piranha.

LAURINDA - Laurinda era doida, não era? Se isso dava ao guarda direito de fazer o que quisesse, por que não daria a ela?

GUARDA - O Guarda respira fundo e continua...

\section{(simultâneas)}

Venha a nós o vosso reino, seja feita a vossa vontade assim na terra como LAURINDA - Ai, meus anjos no céu. O pão nosso de cada dia me caralhudos! Os anjos são sete, 
dai hoje... Peça, Laurinda! Peça!

Mas primeiro, meu Pai, perdoa as

minha ofensa, assim como tenho

perdoado a quem me tem ofendido...

Vê? Laurinda continua pelada...

Apesar de todas as roupas que ele eu

o Guarda dava pra ela, Laurinda

continua pelada, tentando

João de Deus, meu Pai... Não deixa...

Não me deixe cair nessa tentação,

meu Pai... mas me livra de todo mal.

Amém.
São grandes, de espadas

flamejantes rasgando a

Bendita Buceta de Laurinda!

A tentação de Laurinda era a fé

do Guarda...

Ave, Laurinda.

Cheia de racha.

Bendita sois vós entre as

mulheres: peitudas

Bundudas

Bucetudas!

GUARDA - Ah, Laurinda... tu blasfema, mulher! Tu blasfema...

LAURINDA - Laurinda acaricia a Bendita... "O meu pão de cada dia, me dá hoje, Guarda Belo!...

GUARDA - Pois nem só de pão vive o homem, mas sim de toda palavra que sai da boca de Deus!

LAURINDA - O senhor é Deus?

GUARDA - Que pergunta era esta? Eu Ele sou Deus? Que pergunta era esta? Mateus, 4:8. E Cristo, o filho Unigênito, o Advogado da Paz, estava orando e jejuando no deserto quando lhe apareceu, à sua frente, o próprio Satã lhe oferecendo os poder do mundo... e Ele disse: - Não. Não, besta imunda, porque tu fala a língua do Diabo!...

E pensa que vai seduzir João de Deus nas suas tramóia. Mas na minha frente está o Iluminado, o que tudo vê. Ele há de guiar as minhas ação, ele há de me mostrar o caminho. 
LAURINDA - Laurinda tinha medo do silêncio raivoso do guarda. Ela bem que podia orar com ele. Mas Laurinda tem fome, Laurinda provoca. O senhor é Deus?

GUARDA - Ah, Laurinda... Tu blasfema... Tu blasfema, minha irmã. Tu usa o santo nome de Deus em vão! Eu trouxe um pão fresquinho pra você rezar, mas você não quer. Vai ver Laurinda gosta de jejum, não sei. Isso. O jejum ajuda a purificar o espírito.

LAURINDA - Aquele homem que pensava que era Deus sofria de disenteria crônica.

GUARDA - Mostra que você quer a palavra de Deus, Laurinda.

LAURINDA - Era semi-analfabeto.

GUARDA - Eu vou pra minha salinha, minha irmã.

LAURINDA - O único livro que "pensava” que sabia ler era a Bíblia.

GUARDA - E de lá, só volto se ouvir você rezar! Se ouvir você rezar!

\section{Guarda sai batendo a porta.}




\section{Cena 03}

GUARDA - Quarta-feira, onze horas... Não. Onze e meia da manhã. É a hora do almoço de Laurinda. O guarda trouxe um prato de comida quentinha. Vê? Hoje ela vai rezar, fé em Deus.

LAURINDA - Desnorteada de fome, Laurinda vaga pela cela...

GUARDA - Merda, o Zero Hora ainda não trocou a lâmpada. Vai acabar sobrando pra João de Deus. O Guarda para em frente à cela de Laurinda.

LAURINDA - O cheiro!

GUARDA - Laurinda. Te trouxe comida. (com um pó branco, “desenha” a comida) Arroz. Muito arroz. Feijão, caldo grosso. Macarrão, carne... (limpa o pó, como se mudasse de idéia) não, carne não. É Semana Santa, não se come carne. Mas eu lhe fiz um ovo estrelado... Vê, minha irmã? Vê?

LAURINDA - Me dá minha comida!

GUARDA - Dou. Dou essa comida inteira pra você! Basta aceitar a palavra do Divino, do que tudo vê, minha irmã, e eu lhe dispenso do jejum...

LAURINDA - Laurinda sente o cheiro atravessando a porta... Dai pão a quem tem fome!

GUARDA - Reza, minha irmã... Eu Ele sabe que você consegue, eu sei... pega com fervor a palavra de Deus Pai... Vamos! Reza! Pai nosso que estais no céu...

LAURINDA - Senhor Deus das Contradições! Você tem que cuidar de mim, Guarda Belo! Ama a teu próximo como a ti mesmo, homem! 
GUARDA - Eu amo... Eu amo, Laurinda, eu amo... É por amor a Deus e a você, minha irmã em Jesus, que estou fazendo isso. Escuta, Laurinda... Você não entende porque você é doente, mas eu tô aqui pra lhe tirar desse lugar, lhe fazer subir e tocar a mão do Salvador.

LAURINDA - Tem gente que não deixa Deus em paz... Fica falando em nome dele, pedindo, orando. Tem gente que faz da vida de Deus um inferno!

GUARDA - Língua de cobra, você! Você não merece Deus, Laurinda! Você não merece comida!

LAURINDA - Filho de uma égua!

GUARDA - Vê como ela fala com João de Deus? Eu tô aqui pra lhe fazer o bem e você me trata assim?

LAURINDA - Filho da puta!

GUARDA - Olha a língua, Laurinda. Eu não disse agora a pouco que ela era uma perdida, uma meretriz, uma assassina de criança? Foi por isso que sua família te largou aqui.

LAURINDA - Cão do inferno! Cão danado! (Laurinda está transtornada. A voragem ameaça tomar conta dela). Três dias... Três dias sem comer! Ordinário!

GUARDA - Não fala assim comigo! Eu Ele é o Guarda. Ele é o Guarda João de Deus.

LAURINDA - O turbilhão me pega, me enrola lá em cima, eu fico torta...

(...) qualquer coisa me pega em sonho e faz de bola bola bola. 
GUARDA - Laurinda... Laurinda, me escuta... Eu tô tentando, gente, eu tô tentando tirar essa mulher desse lugar que eu não alcanço... Laurinda não se deixa levar... Fica aqui, Laurinda, não entra...

A dor de barriga do Guarda... Perdoa, ó Iluminado, a culpa não é minha, é dessa mulher... Escuta! É dessa mulher que me faz entrar no pecado da ira. Por que eu, meu Deus? Eu tento ajudar as pessoas, mas ninguém deixa. Eu tô tentando salvar essa alma... Laurinda não deixa. Ela fica pelada, meu Deus. E falando essas coisas... Eu preciso fumar um cigarro, eu preciso fumar um cigarro... ajuda a aliviar a dor de barriga, sabe? Ah... E pensar que cigarro causa câncer no estômago... 


\section{Cena o4}

LAURINDA - Não pode, Laurinda. Não pode! Mas Laurinda já estava lá, naquele corredor longo, mal iluminado e cheio de curvas... Com o coração aos pulos e ardendo de desejos, Laurinda roça nas pessoas que entram e saem do lugar. A gruta mais quente da cidade! (ela ri) $\mathrm{O}$ tom vermelho... aquela música... (ela pega a pinga no "bar do Salvador" e bebe) Que delícia! A entrada era uma boca escancarada! Laurinda, a Linda se esbalda, rola, trepa, geme a noite inteira. Quando amanhece, a boca cospe Laurinda que precisa se recompor.

GUARDA - Laurinda tava surtando...

LAURINDA - Quando Laurinda volta pra casa, é presa no quarto. Trancada. Mas a barriga cresce assim mesmo. O tempo engordou Laurinda.

GUARDA - Era a falta de remédio. Mas eu não vou deixar, meu Deus. Eu não vou deixar.

LAURINDA - Todas as mulheres da família reunidas no salão nobre... a mãe, as tias. Laurinda procurou pelo pai, mas ele a havia deixado sozinha. Laurinda não queria tirar o bebê, Laurinda pediu: Me deixa ficar com ele! Deixa! Mas vieram as titias, cacarejando à sua volta... Apesar dos esforços vigorosos que Laurinda fazia, pisotearam a superfície do seu corpo como se fosse um montão de esterco e rasgaram a bicadas, até sair sangue, os lábios flácidos da sua vagina inchada.

Já com as vísceras saciadas, elas foram ciscar a poeira do pátio e Laurinda, limpa, levanta-se trêmula, coberta de feridas, como alguém que desperta de um pesadelo.

GUARDA - Laurinda... Laurinda, minha irmã, sou eu. João de Deus...

LAURINDA - Lá estava ele...

GUARDA - Engraçado... O olhar de Laurinda tinha mudado. 
LAURINDA - Aquele deus grego negro, todo desenhado, chamando por ela.

GUARDA - A Eva tinha um olhar de fêmea no cio...

LAURINDA - Há muito tempo que eles já vinham se espreitando. Mas agora estavam um diante do outro. Ela amolece e o convida com a cabeça e logo com o corpo todo. Vem, vem, vem...

GUARDA - Eu não vou ceder à sua tentação, cobra da luxúria, cobra do pecado. Olha! Vê como ela se esfrega na porta, nas barra.

LAURINDA - Laurinda pegava fogo e crepitava enquanto percorria cada palmo...

GUARDA - Oh, meu Deus! João não vai ceder a tentação da luxúria, do pecado. Sai de mim, Madalena.

LAURINDA - Laurinda deslizava por aquela superfície negra, morna, úmida... virava bicho.

GUARDA - Sai, sai... Sai, Madalena! Me deixa em paz! Ah, sua barriga dói... O guarda precisa escapar... fugir!

LAURINDA - Vem, meu anjo negro, meu príncipe de ébano. Vem pra sua Laurinda, a Linda... Bendita entre todas as mulheres... vem, vem! Eu preciso desse calor humano... O guarda abandona a porta do cubículo e procura um lugar para cagar .

GUARDA - Essa mulher me tira da cabeça, meu Deus. Ela não é uma, é uma legião... Tinha hora que João de Deus perdia a certeza do que tava fazendo. Ele parecia pequeno demais pro propósito divino. Perdão, meu Deus! Eu não devia tá com esses pensamentos... O Senhor é meu pastor, nada me faltará! Eu preciso é dum cigarro, ajuda a aliviar a dor, sabe? Solta os gases. E pensar que fumar causa câncer na próstata. 
LAURINDA - O tempo engordou Laurinda. "Laurinda tá prenha", "Laurinda embuchou"... Não pode, minha filha. Não pode. De novo, Laurinda não tinha escolhas. Mas dessa vez, Laurinda não insistiu. O filho foi-se, como o outro. Mesmo assim, eles a trouxeram pra essa casa.

GUARDA - Vou tornar aqui a própria casa de Javé. Eu Ele vai se munir com as arma do Senhor Deus! Vou purificar esse lugar. Eu prometo, meu Pai, cumprir a minha missão.

LAURINDA - O pai prometeu que quando Laurinda ficasse boa, ele ia buscá-la.

GUARDA - Eu vou tirá Laurinda desse buraco pestilento, vou fazer ela subi as escadas do Paraíso e se sentá a esquerda do Trono, feito Maria tecendo sua reza... Já tô até vendo!!! É isso! É isso que eu preciso fazer (O guarda se recompõe.) Vou cumprir minha missão! Aí o Senhor me livra desse inferno! (Sua sombra, um crucifixo).

Rei dos reis. Na sexta-feira, às três horas da tarde, Laurinda vai tá pronta pra receber a palavra do Pai, não vai ser eu que vou bater os pregos não senhor. Já carrego as minhas chagas. Sexta-feira, às três horas da tarde, uma alma estará salva. Em nome do Pai, do Filho e do Espírito Santo, amém.

LAURINDA - Aqui ninguém liga pra ninguém. Meu cérebro vertiginoso me deixa solta no ar!

GUARDA - Cordeiro de Deus, que tirai o pecado do mundo, tende misericórdia de $\operatorname{mim}$.

LAURINDA - Ela precisa fugir do turbilhão da memória... Ela precisa...

GUARDA - Cordeiro de Deus, que tirai o pecado do mundo, tende misericórdia de ti. Cordeiro de Deus, que tirai o pecado do mundo, tende misericórdia de nós.

\section{Laurinda começa a escrever.}


LAURINDA - Ela precisa... Ela precisa das palavras escritas. A brincadeira de ser louca exaure Laurinda... um existir difícil, vagaroso. As coisas externas machucando... 


\section{Cena 05}

\section{Laurinda em um silencioso trabalho de escrita nas paredes.}

LAURINDA - Ninguém sabia, mas ali, naquele cubículo, Laurinda prepara um livro. Sua vida. A solidão branca dos corredores. A solidão branca de sua carne que ninguém toca. Ninguém ama. Quando Laurinda era criança, Laurinda era má. Por isso seu pai tinha colocado ela ali, naquela casa de doidos. Pra ficar de castigo... Seu pai gostava de marrom. Laurinda pensava colorido: as mulheres eram vacas amarelas. Laurinda é quase sempre neutra.

Branco. O hospício é branco. Branco como ela. Quando era criança pensava que Deus era um olho vigilante. Deus vê tudo. Laurinda é má. Deus castiga. Laurinda escreve. Deus foi o demônio de minha infância. Cheiro de fezes, urina. Comida com bicho, podre. Ratos passeiam à noite. Moscas bóiam nos copos de café. O hospício é deus.

Laurinda esbarra na porta. Senta-se e começa a escrever freneticamente. 


\section{Cena o6}

\section{Entra locução de rádio.}

RÁDIO - Hora do Angelus.Eu vi minha mãe rezando, aos pés da Virgem Maria. Era uma santa escutando, o que a outra santa dizia...

Guarda abre janela do seu quarto e anuncia.

GUARDA - Quinta-feira, seis horas da manhã. Bom dia, seu Moisés!

\section{Entra, em seguida, a Ave-Maria.}

GUARDA - Quinta-feira, sete e meia da manhã. No pavilhão onze, só o guarda, Laurinda e Deus... Hoje o banho de Laurinda vai ser mais cedo, por isso ele eu passei primeiro no bar do Salvador e tomei dois "pingado" para aquecer, pra acender a espada flamejante de São Jorge e pegar tu, dragão, pelo rabo!

LAURINDA - O cheiro...

GUARDA - Sente o cheiro...

LAURINDA - O cheiro da loção pós-barba.

GUARDA - O cheiro de bosta, sangue... O cheiro de enxofre. Agora tu, João de Deus, vai entrá na Cova dos Leão... pega com Ele, que é a Luz, o Poder e a Glória para sempre...

LAURINDA - Lá vem o Guarda Belo exercendo sua caridade... o egoísmo domina a caridade. 
GUARDA - Jesus amado! As palavras de luxúria, do pecado impressa nas parede. Os escrito do demônio. Tá na hora de trazer luz pra esse lugar. Hoje Laurinda vai ser batizada, vou expurgar o mal dessa mulher. Cadê tu? Cadê tu, Capeta? Não adianta se esconder, lúcifer, belzebu... cramunhão...

Ah, tu tá aí... cobra imunda. Hoje vou te limpar dos seus pecados. (ele começa a "purificá-la", jogando farinha de trigo sobre ela) Em nome do Pai, do Filho e do Espírito Santo. Eu te expurgo, eu te expurgo! Vou te transformar em Maria, sua Madalena. Sai, sai, sai tu, Capeta! Até hoje tu tava morando aqui, mas de aluguel... Pois com Deus é casa própria. (ator purifica o lugar, enlouquecido.) Com Deus é casa própria!

LAURINDA - Não é possível que eu me acostume nunca. Cada um no seu papel! (começando a escrever nas paredes) O desespero tem três metros...

GUARDA - Não vai sobrar um só canto onde a mão de Deus não tenha tocado! Hoje eu vou expurgar o mal desse lugar...

LAURINDA - Laurinda se inscreve nas paredes... O Guarda invade a cela de Laurinda, seu estômago...

Você não vai conseguir me apagar... estou impressa em cada poro...

GUARDA - Pois o olhar de Javé vê o caminho dos homens e observa as suas vereda. No reino do céu, só os puros de coração hão de entrar! (olha Laurinda.) Não adianta ficar aí resmungando... Eu vou te encher da palavra de Deus!GUARDA - Pois eu vim pra limpar esse lugar, essas parede... Me encara besta imunda! (começa a esfregar Laurinda com uma vassoura.) Eu creio em Deus Pai, Todo-Poderoso, Criador do Céu e da Terra...

De agora em diante, só a palavra de Deus vai reinar! Eu vou te transformar em Maria, a Pura. Maria, a Virgem, a Imaculada, a Mãe de todas as Mães. Maria, a Santíssima. Olha o coro do bicho. Agora Laurinda tá pura, Laurinda tá preparada... Laurinda, minha filha, veja. Minha filha, agora tu tá preparada... Vem, Laurinda, eu vou te levar pra receber a visita do Pai. 
LAURINDA - Meu pai? Meu pai veio me buscar?

GUARDA - Sim... O Pai, Laurinda. Ele é a luz, o poder e a glória para sempre. Ele está aqui, no pátio, chão de terra batida, uma árvore morta e dois bancos de cimento. Isso... Debaixo do sol, onde a palavra de Deus tem mais força.

LAURINDA - Pai? O senhor veio me buscar?

GUARDA - O Pai está aqui, Laurinda. Pra te receber. Basta que você se arrependa...

LAURINDA - Pai, me perdoa. Foi sem querer... eu não queria quebrar a asa...

GUARDA - O Pai perdoa tudo, Laurinda. Porque o Pai é infinitamente bom. Basta dizer uma palavra e estará salva.

LAURINDA - Laurinda esperava que o pai a abraçasse, a perdoasse. Que ele a pusesse no colo e fosse para o pátio brincar...

GUARDA - Vamos, Laurinda. O Pai perdoa, mas você tem que tentar, você consegue... Pai Nosso...

LAURINDA - Olha, pai, olha... (Laurinda brinca de pular corda.)

GUARDA - Isso, filha. Mais alto, pra chegar no Pai. Pega com a palavra do Divino.

LAURINDA - Eu tô cansada...

GUARDA - Você tá quase conseguindo... aceita o Pai.

LAURINDA - Eu tô com fome... 
GUARDA - Pega com o Verbo pra se fazer carne...

LAURINDA - Pai, me tira daqui!

Laurinda se abraça a ele. O guarda, meio sem jeito, a segura.

GUARDA - João de Deus podia sentir a carne dela. Branca... Dava pra ver os ossos. Pela primeira vez o guarda viu o quanto Laurinda tava magra. Há muito tempo, ninguém visitava Laurinda.

LAURINDA - Agora, nos braços de seu pai, Laurinda se sentia em casa.

GUARDA - Ela se agarrava a ele. João de Deus também não tinha ninguém. Enquanto Laurinda beijava seu rosto, seu peito, seus ombros, João de Deus sentia o coração bater mais forte.

LAURINDA - Laurinda abraçava, beijava o pai e era de novo feliz. Como quando era uma menina e seu pai a punha no colo.

GUARDA - João de Deus podia sentir a quentura dela. O cabelo macio, a carne, o cheiro.

LAURINDA - Pai, me leva pra casa!

GUARDA - Vou te levar...

Sem que perceba, a carência de amor faz com passe rapidamente para o sexo. $O$ guarda, entre a culpa e o desejo, se torna cada vez mais violento. Ele machuca Laurinda. Ela, que no início estava contente, começa a ficar assustada e tenta se desvencilhar do guarda. Ele a estupra. Ação silenciosa. Só os barulhos da resistência e do prolongamento do gozo dele. Ela já se calou. Nem resiste mais. 
Súbito, fios incendeiam-se, iluminando o Guarda com sua luz de fogo. Exalam um cheiro de rosas que toma conta de tudo.

LAURINDA - O guarda se salvou! Glória! Aleluia! Finalmente o Guarda Belo comeu a carne podre do açougue de Deus!

GUARDA - Quinta-feira... que horas são? As horas, já me perdi. Já me perdi. Eu sempre sei que horas são. Que oração?

Pai... pai... Pai, por que me abandonaste?

Guarda sai fechando todas as portas. Passagem de tempo. 


\section{Cena o7}

GUARDA - Sexta-feira Santa, cinco para sete da manhã. O guarda acorda no último minuto. Não faz a barba. Ele sai do seu quartinho na pensão Santa Fé. Passa por porta. Casa. Janela. Hoje, o guarda não passou no bar do Salvador. Foi direto de casa para o hospício.

Sete horas da manhã. Atravessa o portão. Pavilhão onze. O médico não apareceu a semana inteira. Hoje, mais do que nunca, é necessário seguir o tratamento à risca. Por isso, ele, o Guarda, entra na sua salinha e pega o café da manhã de Laurinda. Ele se dirige para o cubículo um.

O guarda para na frente do cubículo número um. (ator se ajoelha ao lado do fosso. Coloca o radinho de pilha ali e liga numa estação qualquer. Vai empilhando os tijolos.) Trouxe pão para Laurinda. Nove da manhã, hora do banho. Laurinda tem que tomar banho de camisola. Onze horas. Almoço. O guarda trouxe arroz, feijão, macarrão. De sobremesa, banana.

Sexta-feira da Paixão. Uma da tarde. Hora dos remédio. Ele faz as vez de enfermeiro. Sexta-feira, três horas da tarde. Hora do eletro-choque de Laurinda.

\section{Som agudo aumenta, junto com volume de rádio. Ator tampa seus} ouvidos, contorce. Limite. Silêncio. Ele toma um trago de pinga. Ator se levanta e pega a vassoura. Varre o chão da sala.

GUARDA - Acabou a visita. O horário aqui é de segunda a sexta, até as dezessete horas da tarde. Vamos. Eu acompanho vocês. Eu sou funcionário público, tenho horário. Cuidado pra não esquecer as bolsa debaixo do banco. Cuidado com o degrau. $\mathrm{O}$ senhor tem um cigarro aí? Não? Faz muito bem. 


\section{Anexo B - Materiais textuais do processo de criação da Maldita Cia.: 2005/2007 - Cena Ceia de Natal (dramaturgia de Nina Caetano) e coletânea de contos Cães Domesticados (autoria de Letícia Andrade)}

\section{B.1. Ceia de Natal}

Sala de jantar. Enfeites de Natal. Mesa posta: várias latas de conserva abertas, garrafinhas plásticas de refrigerante e água. Latas de cerveja. Em frente à mesa, a tv está ligada. Há quatro pessoas sentadas à mesa. Comem automaticamente, enquanto assistem à tv.

A mãe tem uma obsessão: a do sucesso familiar. Sempre quer reunir a família para mais um momento fotográfico. Essa será o centro de sua ação: tornar tudo perfeito, como nas fotografias. Buscará ações de conserto, ajuste, adequação de si e dos outros. Pode trabalhar o oposto: cair, às vezes, no caos e na sujeira total, no total desespero.

O pai é um velho paralítico e bêbado. É um peso morto para a família. Ele está bebendo há horas e planeja uma ação de rebeldia contra o domínio da mulher, a quem é submisso. Aliás, planeja isso há anos. Em sua fantasia, adora "visitar" sua família como quem visita um zoológico. É um observador. Quando a mulher não está, é cuidado pela filha, a qual substitui a mãe na tirania. Quando bebe, algo subterrâneo aflora, algo que estava lá nos esgotos desse homem.

A filha é uma típica garota classe média. A juventude a deixa pouco afeita aos valores familiares e, ela, então, resolve se tornar amante do porteiro, o qual acha parecido com um galã de novela. A transgressão torna esses momentos ainda mais saborosos e a filha deseja fugir de casa e ganhar mundo. A família, no entanto, é o peso morto que a puxa para baixo, principalmente o pai, de quem é obrigada a cuidar.

O filho parece não estar ali: como um corpo morto, fica ali, estacionado no sofá, em frente à tv. Come o dia inteiro e sonha em fazer algo sensacional, como as coisas que vê na tv. Adora os programas mórbidos. Às vezes, parece "acordar" e torna-se agressivo, falastrão, exibido. Parece estar num programa de televisão. Aliás todos, em algum momento, devem parecer estar em um talk show.

Há o porteiro, deslumbrado e apaixonado com a menina burguesa, que ele vê como a sorte grande. Por ela quer fazer tudo. Quer viver uma aventura de cinema. Não podemos esquecer do cachorro, do vizinho, da empregada e de todas as possibilidades de personas: sempre pode surgir mais. 


\section{Primeiro momento: a família feliz}

Alguém muda o canal da tv. Música dos Flinstones. Os quatro começam a se movimentar, numa correria, para se ajeitar numa pose familiar típica: pai sentado ao centro, ladeado pela mulher e filhos. Sorrindo, congelam para a fotografia. O filho se destaca do quadro.

FILHO (apontando para os outros) - Aqui temos uma família feliz! A mãe já fez sua primeira plástica! A irmã já passou no vestibular e o pai, o pai já... ele já...

MÃE (interrompe o filho, tentando disfarçar o momento embaraçoso. Sorri como em uma propaganda de margarina) - Ela tinha os melhores filhos do mundo! Ai, como ela amava os filhos! Vem cá, chuchuco! Abraça a mamãe... (se dirigindo a um espectador) Vai, moço (moça)! Pode tirar a fotografia...

FILHA - Mostra o silicone, mãe! É novo! (para o espectador) A mãe é quem delimita funções na casa: pagar um carnê ou comprar cigarros. Há muito ela perdeu a capacidade de andar sozinha e se agarra aos filhos como quem se agarra a uma tevê. Devo perdoá-la.

FILHO - Vejam essa família feliz! (PAI - Partida!) Essa família (PAI - Falida!) pode figurar em qualquer fotografia. Em qualquer propaganda de margarina! Uma família feliz! (PAI Fingida!).

PAI - Senta aqui, filha! Vamos brincar!

FILHA - Desde pequena que o pai brincava com ela. Upa, upa, cavalinho!

PAI - Quer dançar, quer dançar! O tigrão vai te ensinar!

Pai parte para cima da filha, jogando-a no chão. Começa a transar com ela. Em seguida, parte para cima do filho e depois para cima da mãe.

MÃE - Sai, cachorro! Sai! O problema era o cachorro... Será preciso dá-lo, levá-lo, matá-lo?

Pai sobe em banco e coloca os braços em cruz. Os filhos e a mulher começam a jogar sujeira nele, negando-o (imagem de apedrejamento). 
PAI - O homem, sozinho naquele apartamento, feito um cachorro na noite de Natal se prepara para morrer. (ele se prepara para saltar. Cai no chão. Rasteja.) O problema era o pai: disfarçálo? Dá-lo? Matá-lo?

\section{Segundo momento: A tele-visão}

A mãe, horrorizada, observa o pai se arrastando.

MÃE - Não. Pára! (para quem estava fotografando) Pára, pára agora! (disfarça sorrindo, sempre sorrindo). Não fotografa, não, moço. Não com o Jorge assim. Ah, Jorge brincalhão. Brincando no chão! Vai, Alexandre! Pega o seu pai! Vamos ajeitar ele para a fotografia! (Mãe e filhos amarram o pai ao sofá).

FILHO - O pai, mesmo ausente, manda nos meus pensamentos. Ele foi embora quando eu nasci e nunca tive como contratar detetive para achar ele. Ele deve ter seus motivos para ter me abandonado é óbvio. Pode, por exemplo, ter batido a cabeça em alguma quina desses corredores que deixam a gente perdido. Devo perdoá-lo.

Deitam o pai na mesa de jantar e começam a "prepará-lo" para a operação: vão colocando a comida sobre o seu corpo, como se fosse um grande vitelo sobre o qual colocassem as guarnições para servi-lo. Filha vai jogando água dentro da sua boca, obrigando-o a gargarejar para sobreviver.

FILHO (passagem para o porteiro) - Quem sabe matar a família inteira? A mãe, o pai, o irmão, o cachorro!

FILHA - Você mataria? Minha família inteira? Igual naquele filme que eu vi?

PORTEIRO - Mato. Igual na tevê! (vai abrindo mais latas de conserva). 
FILHA - O pai primeiro. Ele abria o peito do pai! Você! Você aí, sentado! É fácil matar a sua família! As facas guinço são as melhores! Aquele homem nunca mais vai vomitar! (obriga o pai a engolir água)

MÃE - Ela era tão carinhosa com o pai!

FILHA - Engole!

Os dois pegam a mãe e também amarram, colocando-a sobre a mesa.

PORTEIRO - Olha! Tem sobremesa!

FILHA - Enfia a faca de novo. No peito siliconado da mãe.

PORTEIRO - Ta vendo, Fátima? Vou fazer você conhecer o mundo inteiro: México, São Paulo, Croácia. Japão. (pára. Observa a mãe.) Ela tá morta!

FILHA - Como? 500 mil espectadores para você abrir uma mulher morta!

PORTEIRO - O prazo de validade venceu.

FILHA - Vai, você consegue! Ta todo mundo olhando! Qual é o cheiro? O espectador quer saber! Não quer? Você aí, meu amigo, quer saber qual é o cheiro?

PORTEIRO (tentando impedi-la de ver/se relacionar com o espectador) - Isso é tudo mentira! É coisa de sua cabeça, não existe! Não existe!

FILHA - Ela ouvia uma voz dentro da sua cabeça. Era a tevê. Este aparelho tão útil é para nós o quinto membro da família. O irmão se trancou de novo, não consegue mais largar a tevê.

FILHO - Ele vê a imagem minúscula em uma tela de 20 por 30 centímetros. A tv é colorida, mas o volume é rascado e a imagem roda a cada cinco minutos. 
FILHA - O irmão se trancou e há anos que não sei se se interessa por homem ou mulher.

FILHO - A vantagem é o controle remoto em miniatura. Gosta de futebol e noticiários policiais. Quem venceu o jogo ou quem foi esquartejado na semana.

FILHA - Quarenta dias sem olhar meu olhar. Quarenta dias sem trepar. Quarenta dias sem vale a pena ver de novo.

MÃE - Estragada de novo! Vocês estragaram tudo! Quem fez essa bagunça? Adriana, traz o sabão para limpar! O dia inteiro abrindo lata, cozinhando leite condensado pra virar doce de leite!

Os dois filhos tentam conter a mãe. A filha enche sua boca de comida.

FILHA - Que isso, mãe? Essa família é feliz!

MÃE (rindo) - O pai não para de beber, é alcoólatra!

FILHO - Essa família é feliz! Todo dia, juro!

MÃE - A filha é uma puta! Uma puta!

FILHO - Eu juro! Isso só ta acontecendo hoje! Só hoje! Noite feliz! Noite feliz!

MÃE - O filho um fracasso!

Vão entupindo a mãe de comida, até ela calar. A música "Noite Feliz" toma conta da cena. 


\section{B.2. Cães domesticados (Letíca Andrade)}

\section{Receita de família}

Em uma sala de tv, acrescente pai, mãe e dois filhos. Teremos o que podemos chamar de família. Acrescente a gosto cachorro, barata e ratos, que podem morar ou não dentro do sofá.

Misture lentamente ódios antigos, empréstimos indevidos, pequenas mesquinharias e mesma televisão de vinte anos, com a antena quebrada. Objeto de disputa, objeto de desejo de todos na casa.

A seguir reserve mãe na cozinha, filho no banheiro, filha no quarto e pai na garagem para depois juntá-los novamente na hora do jantar. Tudo pronto. Agora congele e vá degustando uma porção a cada dia. 


\section{Iniciação pro estrangeiro}

Hoje tomei a decisão. É preciso deixar este lugar. Esta casa. Esta família morta. Toda uma vida vivida num mesmo recinto, olhando a mesma parede amarela, pegando o mesmo ônibus, temendo os mesmos tipos de perigo.

Era isso. O medo na esquina. O bom dia ao porteiro. O almoço ao meio-dia. Os telefonemas para dar. Os consultórios para visitar e o almoço de Domingo. Em frente da televisão. O sofá de chita que era do meu avô, última herança de um homem deletado de nossa vida familiar. Motivos? Segredos seculares.

E as contas para pagar. E as contas para pagar. As contas em atraso. E a água cortada. E o cachorro que vomitou no sofá. E a descarga que quebrou o reparo. E a louça suja.

Porque a mãe dá uma sonsa e só pensa em emagrecer. Diz baixinho que faço o que quero com o pai, que ninguém se importa com seu sofrimento de há anos e que se não obedecermos teus mandamentos rigorosamente seremos queimados vivos nas brasas do inferno.

O irmão se trancou no quarto e há anos que não sei tem barba ou se se interessa por homem ou mulher. Quarenta dias sem olhar meu olhar. Quarenta dias sem trepar. Quarenta dias sem vale a pena ver de novo.

O pai, mesmo ausente, manda nos meus pensamentos, delimitando funções na casa: pagar um carnê ou comprar cigarros. Perdeu a capacidade de andar sozinho, e não consegue mais largar a tevê.

Este aparelho tão útil é para nós o quinto membro da família.

E a Segunda feira e a Terça e a Quarta e a Quinta e a Sexta e o Sábado... Então sento e espero o Domingo.

Porque há coisas que tenho muito medo.

Medo das coisas que eu nunca vou fazer.

Ladrão, barata, e apresentadora de TV.

Farei uma mala porque hoje parto para o estrangeiro: México, São Paulo, Campina Grande. Nesta época, Guadalupe está fora de temporada e os preços estão cada vez menores. De qualquer forma tenho que ter dinheiro extra, caso precise subornar o cara da alfândega.

Vou agora mesmo fazer a mala, agorinha. Levarei máquina de tirar fotos, livro preferido, escova de dente, dicionário e um mapa-mundi.

E o resto de minhas tralhas ficarão por aí, boiando nesta casa como um esgoto a céu aberto.

Meu problema é o cachorro? Será preciso dá-lo, levá-lo, matá-lo? 


\section{Pessoa: solteira, idade: média, estado: alegre}

Na minha casa tem comida de todo tipo: bisnaguinha, toddynho e sucrilhos. Tudo muito saboroso e nutritivo. Faço compras todo Sábado ao meio dia: a hora do rush no supermercado. É mais excitante porque consigo ver todos os meus vizinhos juntos ao mesmo tempo. Durante a semana ficam trabalhando em seus trabalhos ou escondendo em seus esconderijos.

Tem a seção de congelado que gosto muito: tudo muito limpinho e embaladinho. É prático e livre de vírus. Tem a seção de doces, que é linda e colorida, com embalagens que brilham prateado, mas que evito pois já tenho quilinhos a mais.

Na minha casa também tem microondas, facas guinço, a melhor do Brasil e tudo que eu preciso pro meu bem-estar. Sou bem feliz e não tenho o que reclamar. Não tenho cachorro, porque suja muito, mas tenho o Josué, que é meu peixinho beta, cor azul-lilás. Lindíssimo. Ele é um animal bem compreensivo e silencioso do jeitinho que eu quero e melhor: come pouco, muito pouco.

Meu pai foi embora quando eu nasci, e como não tenho dinheiro suficiente, nunca tive como contratar detetive para achar ele. Ele deve ter seus motivos para ter me abandonado é óbvio. Pode, por exemplo, ter batido a cabeça em alguma quina desses corredores que deixam a gente perdido. Devo perdoá-lo. Ser solidário com os outros, diz nas campanhas para arrecadar renda para os mais carentes que nós. Não fico triste, porque sou bem alegre. Não tenho o que reclamar.

Mamãe morreu faz cinco anos, trinta e três dias e dois minutos. Tomou muito remédio de emagrecer, os médicos disseram. Segundo especialistas para não adquirir a mesma doença que pode se manifestar a qualquer momento, devido ao fator genético, devo ter cuidados especiais: ficar longe de medicamentos de qualquer natureza e tomar muita água, que não tem qualquer contra-indicação.

Diante do exposto, desejo expor que procuro companhia, da qual gostaria de compartilhar toda minha vida. Deve ser alguém carinhoso, asseado e de bom caráter, sobretudo. Se você é esta pessoa, ligue-me para conversarmos pois ficarei bem alegre. Não que eu já não seja, mas que para que eu possa ser ainda mais feliz.

De alguém que espera teu telefonema, 


\section{Minha programação preferida}

O porteiro vê a imagem minúscula em uma tela de 20 por 30 centímetros. Preta e branca, volume rascado e imagem que roda a cada cinco minutos. A vantagem é o controle remoto em miniatura. Gosta de futebol e noticiários policiais. Quem venceu o jogo ou quem foi esquartejado na semana.

Enquanto o porteiro masca chiclete na porta em pé encostado na porta da garagem, a doméstica assiste à novela das oito em sua tevê de 29 polegadas na cama da patroa. Esta ainda está no trabalho. A patroa só vive de trabalho para pagar a doméstica e as dívidas que contraiu no cartão de crédito.

A doméstica se acha muito especial, gostosa e necessária ao mundo.

A doméstica ama o mocinho da novela, que usa gel no cabelo, tem cinturinha malhada e fala com a voz grossa e melosa.

O despertador toca. É a hora de levar o lixo para baixo. Sabe que não vai acontecer nada mesmo na novela, pois a revista $A$ favorita dizia que Pedro Augusto vai se declarar à Maria de Fátima só na semana seguinte. Está tranqüila, pode ir terminar suas tarefas.

Vou dar uma pausa, pensa ela. Aproveita para se refrescar: abre a torneira, pega o sabonete para pele delicada e sensível e esfrega nas duas mãos, formando uma massa branca e densa. Passa no rosto, que tem alguns cravos a espera de serem espremidos, e depois enxágua com água até tirar o excesso. Linda, arremata a doméstica para o espelho.

Enquanto isso o porteiro está cheirando rapé. Depois desvia da câmera que tem dentro da guarita para tomar sua cachacinha.

A doméstica desce no elevador cantarolando um pagode que aprendeu na semana passada. Ela caminha em direção ao portão, que na realidade é em direção à guarita do porteiro. Gosta de se exibir. Mostrar as ancas quase perfeitas com apenas três celulites e uma estria, quase invisível. Para vê-lo sofrer a cada dia. O porteiro ama a doméstica, mas a doméstica ama o mocinho da novela. A doméstica faz gato e sapato do porteiro. Não vê a hora de fugir dali e encontrar o mocinho da novela. Já ele quer terminar o curso de eletrônica por correspondência para dar uma vida melhor para doméstica.

No momento que ela passa com seu cheiro de fêmea "filha da puta", ouve-se da televisão que o momento crucial da novela chega: Pedro Augusto revelará que ama Maria de Fátima:

Diz que me ama, suplica Pedro Augusto.

Não consigo entender, retruca estupidamente Maria de Fátima.

A doméstica se morde por dentro: tem pouco tempo para levar o lixo para garagem, subir o elevador a tempo de conseguir assistir ao momento mais importante da sua vida. 
Não há tempo..., chega a balbuciar a doméstica.

O quê?, responde o porteiro.

Não vou conseguir chegar lá em cima a tempo de ver o final..., diz corroída de humilhação.

O porteiro sabe que aquele momento é único e que agora pode fazer tudo o que quiser com a doméstica.

Ela é toda sua.

Três infinitos minutos de novela e ele pode saborear toda submissão de uma mulher gostosa que, de forma egoísta, guarda para si a buceta sem uso ou validade.

O rosto do porteiro se ilumina. Convida cordialmente, com gestos que lembram o mocinho da novela, para entrar na guarita apertada e se sentar ao lado dele na cadeira puída.

Quer o controle?, pergunta o porteiro estendendo o pequeno objeto que falta dois botões.

Não, não precisa, diz a doméstica que aceita sua derrota, engolindo o fel e o amor próprio.

Precisa sim, meu amor, quero que minhas mãos fiquem desocupadas. 


\section{Noções pro suicídio}

(O tratado sobre esta vida banal)

para aqueles que tiveram a sorte de não precisar.

Fiquem sabendo o seguinte: a partir de hoje, sou o suicida da semana. Mande flores para meu funeral, cartões cheios de condolências, ria das minhas falhas, digam que fui um fracassado, e que é uma pena, ah sim, um imenso desperdício, que um jovem tão promissor, dotado, abundante, cheio de vida e energia, tirou a própria vida sem motivo plausível.

Isso. Quero ver a cena. Eu mereço.

Amigos falsos. Artistas invejosos. Parentes distantes. Amores inúteis. Todos, absolutamente todos nestas ocasiões funestas, irão sadicamente se certificarem se fui mesmo pro inferno ou se corre o risco de ser aqueles alarmes falsos que deixam a gente tão decepcionado. Todos que sempre odiei durante minha vida de merda. Todos que me amaram um pouco. Todos que cruzaram comigo na rua. Até aqueles que dividiram comigo o primeiro ginasial. Que tomaram a primeira vacina comigo, naquele domingo gordurento da escola da Avenida Amazonas com rua José de Alencar.

Estes e outros curiosos celebrarão internamente minha derrocada, sentindo todos eles que são mais felizes, mais magros, mais ponderados, mais acompanhados, mais bem sucedidos, mais calmos, mais sortudos do que aquele pobre cadáver exposto no meio de um salão barato de um cemitério de quinta.

Depois de cinco anos exatamente, meus ossos serão jogados pros cães de rua comerem a dentes vistos. (estes simpáticos animais que serão exterminados num futuro próximo nas câmaras de gás)

Será assim mesmo. Já estou no velório ouvindo fofoquinhas, burburinhos, óculos pretos e tapinhas nas costas. Sorrirei irreversivelmente com meus lábios frios e cheios de formol.

Meu irmão herdará facilmente os livros que suei tanto para pagar. Meu pai, distante, voltará a esta cidade, por contra vontade, apenas para demonstrar que honra a minha memória. Palmas. Homenagem que confesso ser dispensável. 
É preciso registrar que em nossa família, as mulheres estão ausentes. Motivos de morte e abandono são as mais prováveis.

Antes, devo confessar que planejar a própria morte não é algo simples. Acrescento que nunca fui simples, muito menos objetivo em se tratando de assuntos de morte. Na realidade, a simples escolha de uma camisa é um problema. Falo sobre a morte porque ela é o ponto de chegada do problema. A grande vilã desta história é a vida, com suas vilanias, mesquinharias. A idéia restrita de gente que só pensa em trabalhar a vida inteira para fazer cirurgias caras e, depois de sofrer muito na recuperação e posteriores cuidados e regimes, tabelas e filtro solar, exibir-se nos shoppings, nas ruas e nos ônibus empoeirados.

A vida, sobretudo a minha, sempre foi funesta. Perdas, mentiras, competições e as melhores baixezas possíveis para se virar. Aprendi desde cedo a furtar a atenção do mundo.

Por isso, sempre fui de tomar alguns remédios pesados e ter mania de perseguição. Muitas vezes com causa e outras por razões imaginárias. Já não sabia distinguir invenções minhas ou crueldade alheia. Talvez pela falta de jeito com gente, passei a colecionar idéias sobre assassinatos, perdas, tragédias inesperadas, acontecimentos insólitos, possibilidades absurdas. Cenas que ninguém gosta de imaginar. Como por exemplo a última trepada antes da morte. Não dá uma pena pensar que você pode morrer exatamente no momento em que sua última transa foi um tédio? Peço muito que isso não aconteça. Porque o primeiro sexo costuma ser meio desajeitado, sem gosto e meio por obrigação. O que vale é abrir a porteira. Mas o último não, o último tem a ver com a honra, é um testamento seu à humanidade mesquinha. Faz provar que você realmente é melhor que muito babaca por aqui.

De volta à morte, ou seja, à minha, comecei a ler romances policiais e a ver todo tipo de filme e sitcoms enlatados para me inspirar de alguma forma. Algumas idéias caíram.

Primeiro. Pular de cima de um edifício famoso no centro da cidade (sei que era óbvia, mas não deixava de ser tentadora a idéia da fama, de um espetáculo derradeiro, um happening ultramega-pós-moderno: "última flama de um coração desesperado"). Mas eu não ia gastar toda uma vida, mesmo que seja a minha, com algo tão bobo. Isso não.

Segundo. Mas o melhor, era se enterrar vivo e ir morrendo aos poucos asfixiado e sendo comido por vermes e formigas peçonhentas. O problema que isto ia requerer outro fazendo isto por mim, o que iria ser impossível, já que ninguém quer ser assassino assim de favor. Assassino que é assassino mata e pronto, não tem essa de pedir não. Além do mais ia ser plágio do Tarantino porque criatividade também é um assunto duvidoso para mim.

Terceiro. Jogar-se na frente de um vagão de metrô em alta velocidade. Coisa épica. Rápido, quase indolor. Ponto. Vejam a notícia no jornal: Jovem se atira no metrô. Sejamos cúmplices e solidários sobre este fato tão comum de nossa sociedade contemporânea. Rezemos pelas almas 
fracas, impregnadas de um pessimismo nocivo ao bem-estar de nossas crianças. Rezemos. Não é preciso tomar nenhuma atitude. Precisamos estar preparados para tudo.

Bom, amigo... e amigas! (o mundo não vive sem as mulheres, elas, maravilhosas e necessárias para o tesão masculino e para a geração de novos cafajestes que devem ser perpetuados), já devem ter percebido que não sou muito bom nisso. Tenho me repetido. Tenho então eis as alternativas: me entupir de remédio, dar um tiro nos ouvido ou me enforcar, com aquele lance de amarrar a cabeça no lustre e saltar do banquinho.

Eu fico preocupado o que vai doer mais, o que vai fazer mais sujeira e o que vai mais me desfigurar, afinal de contas tenho que estar bonito no enterro. Pros inimigos e pras admiradoras que não tiveram o prazer de me comer na vida. Digo "comer" porque sou um homem moderno e as mulheres de hoje estão cada vez mais insaciáveis na cama. "Graças a deus".

É. Acho que o pior é ficar todo estraçalhado do tiro. Além do mais, quero algo que não seja um lugar comum. Talvez, o melhor seja se enforcar, tipo algo meio medieval, um ato meio nobre, coisa de pessoas que se preocupam em preservar certos procedimentos da memória. Todo mundo vai achar que eu pirei de vez e me inspirei nos poetas malditos ou o cacete. Afinal todas essas idéias eram uma fuga. Devo ir direto ao ponto.

Então me sento na cadeira do meu quarto imundo. Abro a última gaveta da escrivaninha, que fica ao lado minha cama. Apanho uma arma de ferro preta pesada com duas balas. Olho pra cima, vejo meu lustre com motivo japonês gravado na estrutura de papel branca. Penso que comecei a gostar de sushi muito tarde na minha vida.

Silêncio. Estouro. Depois. Fico me perguntando para quê saber o que vem depois. Não há ação. Imagem. Sentido. 
Anexo C - Dramaturgia de Cara Preta

\title{
O cara preta - Maldita 2008/2009
}

\author{
Espaço Gruta \\ Sede da Companhia Maldita de Investigação Teatral \\ Belo Horizonte Minas Gerais
}

Estréia 2009

O grupo: Amaury Borges, Admar Fernandes, Lenine Martins, Letícia Andrade, Patrícia

Lanari e Ricardo Garcia

\section{Ficha técnica:}

Atuação Lenine Martins

Direção Amaury Borges

Dramaturgia Letícia Andrade

Textos Letícia Andrade e Lenine Martins

Direção Musical Ricardo Garcia

Músico e sonoplasta Admar Fernandes

lluminação Amaury Borges

Acessoria Técnica em Iluminação Felipe Cosse e Juliano Coelho

Cenografia Lenine Martins, Amaury Borges e Patricia Lanari

Cenotécnica Patricia Lanari

Figurino Maldita Cia

Máscaras Lenine Martins

Costureiro Túlio Souza

Cantos e vozes Letícia Andrade

Vozes e manipulação de objetos Patrícia Lanari

Vozes e manipulação de luz Amaury Borges

Projeto Gráfico Raquel Alvarenga

Fotos Guto Muniz

Produção Geral Maldita Cia

Produção Executiva Lenine Martins, Amaury Borges, Letícia Andrade

Concepção Amaury Borges, Lenine Martins e Letícia Andrade

Gênero monólogo polifônico

Classificação 16 anos

Agradecimento afetivo à Ines Linke, por sua contribuição como cenógrafa na concepção inicial deste trabalho.

Agradecimentos: Alexandre Galvão, Alexsander, Cida, Galpão Cine Horto Joyce Malta, Kenia Dias, Chef Túlio, Preta (cadela),

Este espetáculo foi realizado com os benefícios da Lei Estadual de Incentivo à Cultura do

Estado de Minas Gerais.

Patrocínio Usiminas

Apoio cultural Chef Túlio Butiquim Internacional 
Nota da dramaturga sobre o texto: Em negrito, está expresso o discurso do ator e, em itálico, estão as rubricas.

\section{Quadro I - O Boi}

A porta de entrada da Gruta se abre. Público entra e se ajeita como pode. Não há cadeiras no salão amplo.

Iniciam-se sons, vozes, tambores em meio a chuva, no fundo.

Luzes em flashes, luzes em formatos quadrados. Ambiente em penumbras. Luzes-movimentos.

Atuantes estão no fundo, no espaço da escultura sonora de metais.

Sons de caminhadas no fundo. Sons de tambor, metais e piano.

Atmosfera lúgubre, suspensa.

Entra também nesta polifonia, o som em áudio, que faz um "tapete" sonoro.

Som de chuva. Água que escorre ao fundo, e que se misturando com a lama do lugar.

Vozes e cantos ao longe dos atuantes.

Pode ser escutado um canto...

Levanta tua cara

Pra salvar do tapa.

Sai dessa gruta funda

Que tudo na vida passa.

Sai desse esgoto ingrato

Cospe na desgraça.

Sons altos. Caos. Silêncio. Ao longe, em eco...

Eraldo!... Êh boi...

Luz pisca-pisca. Sons pequenos. Guturais. Aparece uma mão, primeiro, que recorta a janela, depois a cabeça.

O ator tem um barril furado na cabeça. Tomba de um lado para o outro. Cambaleia. Está curvado. A cabeça pesa. Entra pela porta. Silêncios construídos. Levanta a cabeça.

O ator constrói seu espaço, sua narrativa e ação. Pode dizer...

Ele tá com a cabeça atordoada, lotada de cachaça. Lotada de bordoadas da vida. Fede. Não era gordo. Não era um velho flácido. Mas tava sempre inchado, daí o apelido: Boi.

Ele tá apoiado numa calçada. Ele caminha pelas ruas. Caminha se apoiando em muros de concretos. Ele procura um lugar para se apoiar de tudo.

Cai bonito em meio à lama. Patético. Tenta se equilibrar-se. Torna-se cada vez mais patético. 
Luzes em quadrados, como se fossem carros passando numa rodovia.

Tudo passa muito rápido. Ele atravessa a rua. Carros, ônibus, trem, metrô. Lotados.

Pode no caminho bater num poste-cano e dizer...

Porra de poste. Porra de vida. Porra.

Repete. Luz em quadrados no corredor. Som de trânsito. Sirenes de ambulância.

Inicia um caminho reto rente à parede, até um quadrado de tábuas.

Corredores de concreto. Ele segue sem rumo. Avista os arranha-céus imobiliários. JR Construtora. MRV. Ele se encostava nos muros residenciais. Muros de multinacionais. Escornado. $O$ sonho da casa. Tão perto e cada vez mais longe. Aquilo não era coisa feita para gente feito ele.

Interrompe e relaciona-se com um espectador.

Me dá um dinheiro preu compra uma porra de pão, moça.

Eu já te contei que ele era inchado? Sim... de cachaça e borboadas da vida. O corpo meio flácido, meio oco.

Continua deslizando rente aos muros. E naquela virada do morro a grande obra da arquitetura moderna, imponente majestoso: o grande viaduto... pendurado nele, via sedento os grandes out-doors: "coca-cola, sede é tudo".

Na base daquele viaduto, lá estava o barraco. O barraco do Eraldo. Oquei... Eraldo tem barraco próprio. Dois cômodos. $\mathrm{O}$ barraco era tão bem feito que podia ser chamado de casa. Oquei. MRV. O sonho da casa própria. De longe, era o melhor barraco das redondezas. Oquei...

Abaixa a cabeça. Cambaleia pouco. Pausa curta.

Oquei, oquei, oquei, uel, uel...

Respira. Recomeça. Tom irônico e cômico. Patético novamente. Pensa consigo mesmo. Gagueja em volume baixo.

Péra aí, já sei o que eu vou fazer... Vou subir lá em cima... E falo com ele... Oh, Eraldo, se bem que... se bem que podia me... aí eu... que se acha... eu... você... aqui... sim? Sim? Não? Não? Não, Eraldo. Não, Eraldo...

Som de latidos fortes. Chega na frente do espaço ficcional do barraco de Eraldo.

Fala mais alto, como se batesse na porta.

Vai levando sua carcaça pesada para frente do barraco.

Eraldo! É o Boi. Boi. Eu vim para te falar uma coisa. Ce taí, eu tô aqui, então a gente podia... 
Tom patético, pede com “carinho”...

Você podia me deixar morar aqui... oquei, oquei...

Ainda submisso, vai crescendo na sua inveja.

Sim? Não? Eraldo não, não. Sim, sim, sim.

Silêncio, ódio. Cresce no desejo de tomá-lo. Sons de tiros.

Não, Eraldo, o barraco agora é meu.

Bate a cabeça nas tábuas. Ato criminal.

Luz horizontal na máscara-barril. A luz balança.

Morra! Morra! Morra! Porra!

Acalma-se. Pisa nas tábuas como se entrasse no barraco.

O Boi leva para dentro sua carcaça e arrasta o corpo de Eraldo para fora do barraco.

O melhor barraco das redondezas. Vista ampla. Bem posicionado. Lá dentro cama com colchão, fogão e televisão. Tudo limpo e ajeitado.

O Eraldo agora sou eu. O Eraldo agora sou eu...

Deita exausto. Canção “Boi da cara preta”. Passagem.

\section{Quadro II - O Hermafrodita}

A libélula se prepara. Do barril-casulo, deita. Sai tecido-branco-asa-saia de vual.

Música de primavera, pássaros e assovios.

Ela acorda sussurando... SSSSSSSSSSSS. Sai sua, serpente sua suada, sugada, suja... SSSSSSSSSSSS.

SAI: viço, vingado, visgo, voraz, vertigem, viaduto, vida viril, viagem, virulento, viado, virgem...

Calma lânguida... sibila, dada, dá...

Arrasta-se pelo chão. Faz círculos. De quatro, levanta peitinhos. Apronta-se, arruma-se.

O peso do cabelo, loiro, o maldito cabelo dela, nele. Ela tem a noite inteira. Ela, ele, êla se estica, se esparrama, sonha. Com a voz vazada procura seios, maminhas, oleosa serpente que desliza e enraíza pelo chão. 
Mas ela ainda não começou,

Esqueci de uma coisa...

Ela amarra. Agora precisa da força de homem.

Não pode sobrar.

Apalpa a barriga sobrando.

Ela se monta.

A relva cede muito cede pouco, não parece, as peludinhas

Relvado tingido. Um eterno amanhecer

O trocado de todo dia. tudo entra. No seu cofrinho.

Acima de tudo sua voz é suave.

Vai começar seu show assim...

Isso é pouco.

erética

Ele nela, ela nele: ela. Cadê ele, cadela.

Agressiva, fera.

Primavera, vera, fera, ela vocifera quando alguém chega perto.

Música Volare. Sons acústicos de água sendo derramada em copos de vidro.

Abre a calça, pêlos pubianos à mostra. Sons de pássaros. Música suave. Dança da púbis.

Dança pelo espaço. Delicada.

Ela meio donzela. Bela, moça delicada, muito perfumosa, um pouco atirada e um tanto desastrada. Inferna, infernal, pega fogo onde não pode mais... A onda espraiando em si, sim, si mesma...

Cai com classe e se ergue de novo, com classe. Delicada novamente.

E da sua vulva viúva vagina vitória régia nasce, cresce e fenece teu trajeto azul.

Nada nêla parece natural, tua graça de virgem celestial. As faces ruborizadas, embebida na sua embriaguez. Já os pêlos grossos insistem em nascer viris no seu sexo, na sua cara grossa de macho em gestação. A pele dura e estriada do peito masculino se mistura à pele das ancas gordurosas da mulher.

Macho. Agressivo.

Leviana, não. Másculo, sim. Traiçoeira, um pouco. Sorrateira. Rogada, nunca. Meio fina, meio grossa. Febril, sim, sim, sim... agora ela se prepara para o primeiro vôo. $O$ vôo da libélula.

Dança de grinaldas loucas. Ritual noivado. 
Vozes.

Voa borboleta azul... Voa, donzela, voa pássaro protuberante... asas e viço...

Alucinação. Alicia. Delicia. Pega um mastro-falo de ferro imenso.

Ela mastruço. Inteira. Fada. Não. Puta. Não, fada. Safada. Não. Só fada. Só foda.

Manipula como se fosse uma carruagem, acena com mãos de Miss.

Vozes.

Tudo que ela queria era uma "bonita", B-U-C-E-T-A, de primeira qualidade, senhores e senhoras. Voa... decaída, mas voa...

Luz de gaiola no espaço do salão amplo.

Manipula mastro-falo de ferro masturbando-se, trepando, em direção à porta.

Música do piri-piri-piri-ai!

Dança mais e depois interrompe. Na escada. Percebe uma presença.

Tudo muda rápido. Rota. Cega da noite passada. Percebe a presença de um inimigo invisível. Dá um aceno com sua mão e joga um sorriso indecente de deleite para aquele olhar negro que tinge sua vergonha. Não consegue guardar sua feição. Dele. Tudo escuro sua cara escura, negra, que cegava ela. Chamava ela. A presa na rede do caçador.

Pega máscara bandido. Passagem para O merda.

Ele, sozinho. Olha ela. Procura. Acha. Eu fico quieto, quieto, êla não me vê.

Põe máscara na mão. Jogo de dois. Ator está na escada, apoiado, desliza.

Quadro III - O homem negro mata a mulher

Narrando e observando hermafrodita. Ele está no poço.

Mais bonita do que qualquer mulher que ele já possuiu. Ele a observa. A barriguinha branca à mostra. Pele que brilha, macia, macia... Cobra, ele olha ela. Com desejo, olha para ela, ela uma festa. Fada, safada. Ele queria ver sua mulher sempre perfumada, arrumada e silenciada, toda noite, todo dia, naquela mesma hora.

Desliza para o chão. Ele põe a máscara preta no rosto.

Naquele dia, ela estava mais radiante do que o costume. Aquilo era demais. Aquilo deu raiva nele. Foi crescendo um ódio nele, em ver tanta lascívia, tanta vida. Um excesso que ele não permitia nela. Aquilo era demais. Ela tinha passado do limite.

Prepara-se para ato criminal contra ela. Luz vermelha. 
Ele não se agüenta. Dessa vez ela vai ver só uma coisa.

Na saída do baile, ele e ela entram no carro e ele, com os dois punhos fechados, vai acertando murro nela onde pegava mais. Numa hora, ela foi arremessada no meio-fio. Juntou gente. Depois deu tanto nela, que acabou quebrando osso e dente. Na última vez que isso aconteceu, bateu ainda mais depois, porque ela tinha ficado inchada e roxa e ele queria que a sua mulher se cuidasse, apesar de tudo.

Agora, ele grita que é só uma puta e arranca espalhando pneu.

E ela, libélula acertada, diz que ele é dois... E que o melhor deles não é o que está nessa hora... Ela sai andando... Se equilibrando mal no salto quebrado.

Ato criminal. Ela some. Passagem para o Merda. Ator em pé, arruma camisa e culhões.

$$
\text { Quadro IV - O Merda faz a festa e a merda }
$$

Inicia no salão amplo. Narração no microfone.

Uma tevê sem imagem ilumina o espaço.

Ator continua.

Merda...

Vê a merda que o lugar está e o público.

Merda de vida. Merda de lugar. Todo dia nesta merda de horário, ele toca essa merda de música.

Ganha a simpatia do público, depois acusa.

Vocês estão todos com cara de merda. Então vamos falar da gente? Vão falar de coisa boa.

Espera reação do público. E depois continua.

Então vou falar de mim. Cês gostam de festa? Então eu vou contar pra vocês. Teve um ano novo que eu e uns chegados meus resolvemos sair para fazer uma festa. Então eu vesti minha melhor bermuda e me equipei todo. Nós vamos virar bem. Decidido. 22. A festa é nossa. A festa é sua.

Direciona-se para a porta do espaço interno da cozinha. Relaciona-se com o espaço.

A gente já passava pela porta da cobertura e cumprimentava o porteiro.

No espaço interno da cozinha, o ator liga uma luz branca minúscula que ilumina o lugar. O público acompanha o ator.

Pah. Todo mundo calado. No chão. Chegando lá: era uma cobertura de primeira, festa de primeira, canapé, caviar, champagne e whiski, mulherada oxigenada, siliconada, tudo turbinada. Tá todo mundo confortável? 
O atuante muda o tom de seu discurso bruscamente.

Então todo mundo bota a mão na cabeça e vai me passando tudo que tiver. Vamo conhecer a casa.

O banheirinho dá hora.

Ele se direciona para o espaço do banheiro interno e para o espaço chamado bar, onde estão o técnico de som, geladeira e fogão. Oferece uma cerveja para o espectador. Depois o trancafia no banheiro.

Hoje é festa. Saúde. Ao ano novo que começa.

Peguei a empregada tira os peito para fora.pah-pum.

Vamo fazer um jogo. Falei com os meu mano.

Peguei o mais engravatado e pedi dá três passos para trás e então pah! Miolo para todo lado

Pega microfone, voz em eco

Entra no espaço amplo

Cama king-size

Subi na cama e caguei merda pra todo lado, juntei o lençol de seda. E limpei gostoso. Seda é que bom para limpar o cu, papel higiênico é uma merda. Eu que sou o criminoso? Remorso nenhum.

Assunto do dia.

\section{Mãe remorso nenhum em vez de trabalhar pediu pro menino}

\section{Notícias narradas:}

- $30 \%$ dos 400 mil presidiários do país estão em situação irregular. Maioria dos libertados é de detentos provisórios. Entre as frases mais ouvidas nos presídios estão: "Eu tenho direito a benefício" e "Já cumpri a minha pena". De tão repetidas, tornaram-se banais. A maioria dos libertados é de detentos provisórios, soltos por excesso de prazo da prisão temporária. Um deles, que não teve o nome divulgado, estava preso havia cinco meses, sem condenação, por furtar um pote de margarina e uma escova de dentes. Outro, na cadeia havia um ano, tentou furtar uma garrafa de uísque. As informações são do jornal "O Estado de S. Paulo".

- Estimativa de R\$ 1 mil por pessoa é contestada por especialista privado. Para ter um novo presídio em Pernambuco, o Estado vai pagar ao longo de 33 anos R 3,9 bilhões, o que significa que cada preso custará R 3.150 por mês. Em Minas, ganhará licitação semelhante o consórcio que oferecer um valor mais baixo que o teto de R $\mathbf{2 . 2 0 0}$ mensais. São nesses dois Estados que parcerias público-privadas (PPPs) para a construção de presídios estão em estágio mais avançado."Só que esses custos não levam em conta os devidos investimentos na construção do presídio", afirma o engenheiro Rubens Teixeira Alves. Ele é consultor de um consórcio formado por construtoras e empresas de segurança privada que disputam a concorrência em Minas. "Um valor mais correto seria de R\$2.50o por preso". 
Matar, matei, dois, um de facada outro de tiro, o primeiro queria me passar pra trás e eu, shut, shut, e o outro queria se engraçar, então eu paf, paf, paf... miolo e merda pra todo lado. Remorso nenhum.

Eu não tenho remorso, você sabe por quê?

E a menina que foi jogada pela janela, pai de merda, foi na da amante, joga, joga, joga! Jogou, culpa da safadeza e eu que tenho que ter remorso? Eu nenhum. Culpa da mãe que devia olhar, saber se come e se dorme, com quem ta, mas não, timba! e a menina tava lá estarrachada no chão para todo mundo reparar e falar mal. Merda de gente. $\mathrm{E}$ a história do baseadim? A mãe diz: "faz mal não, meu filho, vai vender uns na rua hoje para comprar o que de comer". E eu? Remorso nenhum.

Devia tudo tá tudo no SEGURANÇA MÁXIMA.

Por isso que eu mato mesmo... Onde tá os Direitos Humanos? Tomando cafezinho? Falando mal do país ou cagando muita merda nos banheiros públicos. Tudo bando de merda.

Se eu fosse o dono da prisão, sabe o que eu fazia?

Eu abria as grades num dia de visita e quando o bando de merda saísse ia mandar atirar em cada um... Abate geral! Bam, bam, bam! Quando me perguntasse o que aconteceu ia dizer que os merda tinha tudo fugido, quem ia contradizer, quem ia dar falta de uma meia dúzia de merda? Tudo no SEGURANÇA MÁXIMA. Remorso nenhum... Doa a quem doer. Eu não tenho medo de morrer mesmo... a vida é uma merda mesmo... não é mesmo?

A vida é uma merda, merdança, não cocô que é duro, mas merda mesmo mole de fedida.

Cuzinho eu como, sim, todo dia e venho atrás arrancado a merda que sobra. Merda de vida...

Vocês tão tudo na merda. Eu vivo na merda. Oquei

O presídio é escritório. Eu mando aqui.

Som de hino. Fala forte. Bate no peito.

Merda, merda... Oquei...

Passagem para submissão.

Oquei...

Direciona-se para o corredor de entrada onde há uma porta de ferro ao fundo e pega o mastro, que manipula como se fosse uma metralhadora. Repete até o fim.

Oquei... Oquei... Oquei... 
Passagem para o homem lama. Ele chama as pessoas para entrarem no espaço interno da cozinha.

$$
\text { Quadro V - O homem onça, de lama no rosto e botas nos pés }
$$

Entra para espaço interno. Coloca botas. Entra comendo barro/carne/Preto. Máscara corpobarro.

Tá com medo? Mecê acha que eu pareço onça? Tem horas em que eu pareço mais.

Eh onça gosta de carne de preto. Quando tem um preto na comitiva, onça vem acompanhando, seguindo escondida, por escondidos, atrás, atrás, atrás, ropitando, tendo olho nele.

Carecia de viajar sozinho, e ele vinha lento, tinino de medo roxo e eu, eu vinha no encalço, cheirando o pó da sua bota, arqueando o corpo e lambendo com os olhos.

Eu não tava achando nada de ruim não, tava jeriza não, gostei do preto, tava com dó dele, em mesmo, queria era ajudar, por causa que ele tinha muita comida boa, mantimento, por pena ele carecia de viajar sozinho. Com aquele medo doido, ele não me largava em hora nenhuma. Preto conversava, conversava. A gente caminhamos duas noite e três sol. Depois aquetava e comia. Ele tinha farinha, sal, queijo, rapadura, feijão carne seca, tinha anzol para pegar peixe, toucinho salgado. Ave-Maria preto carregava tudo no lombo eu ajudava não. Eu caçava: matei veado, jacu, codorna. Ele comia, falava em comida, ficava vendo ele comer, ficava empanzinado. A gente perdendo rumo e ele ali, comendo com a boca cheia de dente banguelo e amarelo. Foi quando eu olhei o nego com aquela alegria doida de comer e fiquei com raiva daquilo, raiva danada. Se ria à toa, o preto. Enquanto isso, a onça morena, vindo de fio, pela mata escura, via e vinha com fome de preto.

Para um espectador.

Oncê não fica com raiva, não? Bem que se ia gostar do preto, caridoso, bom proseador e ia te dá o que de comer.

Aproximação. Toque. Retoma a ação.

Pois aí que a raiva foi raleando e eu queria era brincar com o preto. Saí calado, calado, que nem nenhum ninguém. Tirei-o de comer com boca boa à toa e levei todo, todo e escondi em galho de árvore. Adornar a caça para entregar o pobre para a diaba sarapintada.

Só que diaba, a onça danada nem não vinha, sumia na escurecida e o preto lá de olhos arregalados, andava em roda zuretado, procurando o caminho das rede. Mas ele tava com medo de gritar e espiritar a onça e falava meu nome baixinho.

Eu esprei, trepado no pau, minha encomenda tava acertada, mas ela pegou no mau gosto comigo, fiz ofensa de espriar, fiz zanga com o preto e ela sarapintada e ardida ficou lá só lambendo com os olhos, eu, eu, eu.

Para o espectador.

Hum, hum, oncê gosta de ouvir, eu conto, mas eu tava na obrigação. Oncê ia fazer no meu lugar? Preto não prestava não era só de oferecer, era só de obrigação. 
Oncê presta, cê é meu amigo, minha presa. ói deixa eu ver oncê direito, deix' eu pegar um tiquinho em oncê, tiquinho só, encostar minha mão...

Passagem. Recuo, estranhamento, defesa.

Oncê não brinca não, mexo não, tou quieto, sai pra fora, o rancho é meu. Atimbora. Matei preto não.

\section{Canção para o preto}

Preto veio morreu ontem

Tua alma avuô

Levando na bota suja

Suja de amor e dor

Leva na tua bota suja

O desgosto do favor

Onça braba vem esgueirando

Vem pedindo a obrigação

A cobiça vil dos home

E das alma do demônio

Preto veio morreu ontem

Tua alma já se foi

Vô pedindo a licença

Pra mandar embora o defunto

\section{Canção para a mulher viril}

Ela vem na madrugada

Ela vem lambendo a saia

Essa puta me desfruta

Hermafrodita

Sua maldita dita

Ela é bem sarapintada

Que acorda maquiada

Donzela mal falada

Cadela injuriada

Menina bem safada

Vestida

Hermafrodita.

Sua Maldita dita 


\section{Anexo D - Projeto de Pesquisa: Às margens do Feminino: Texturas Teatrais da Beira}

Pesquisadoras Responsáveis: Elvina M. Caetano Pereira (Nina Caetano)

Lissandra Guimarães Silva

\section{Apresentação}

A dramaturga Nina Caetano e a atriz Lissandra Guimarães desenvolvem, desde 2002, como eixo de seu trabalho, a investigação, junto à Maldita Cia. de Investigação Teatral, de uma obra em processo que busca a horizontalidade nas relações criativas por meio dos princípios de uma criação colaborativa, visando construir uma obra contemporânea de natureza co-autoral. Em consonância com essa investigação de caráter estético-ideológico, elas vêm, desde 2007, pesquisando aspectos da cena contemporânea por meio de diálogos criativos que vêm sendo desenvolvidos, em uma rede colaborativa, junto a criadores-pesquisadores independentes. A fim de aprofundar os elementos dessa pesquisa, o Obscena, agrupamento independente de pesquisa cênica coordenado pelas pesquisadoras, propõe o presente projeto.

Características do projeto: Consiste em experimentos cênicos, ou seja, na investigação de cenas a partir de materiais referentes ao universo marginal da mulher e a partir da revisitação e reterritorização das relações entre o teatro e o espectador, o público e o privado, a teatralidade e a sociedade do espetáculo. Nesse sentido, o experimento propõe uma ação interventiva no cotidiano social através da ação teatral, com a perpectiva de provocar uma atitude ativa do espectador no acontecimento cênico. A criação cênica se dará em uma rede colaborativa, em que as experimentações se retroalimentam através não só de um diálogo constante entre os pesquisadores envolvidos, mas também por meio da participação do espectador/colaborador em diferentes estágios do processo de criação, uma vez que o projeto inclui ensaios abertos, intervenções na rua e realização dos experimentos junto aos atores sociais pesquisados.

São eixos norteadores da pesquisa o procedimento "Work in process" a partir do trabalho préexpressivo atoral, a investigação do conceito de instalação/ocupação de espaços públicos e urbanos, a gramática gestual e verbal da atuação rapsódica e o modelo não representacional de ações (proposto por Artur Barrio), visando uma maior amplitude de possibilidades cênicas e a recuperação da instância narrativa das matérias textuais utilizadas (documentos, relatos, tratados científicos etc.). 


\section{Referencial Teórico: delimitação do objeto}

Esse estudo partirá de algumas premissas:

Em primeiro lugar, é preciso entender o texto teatral não como "literatura dramática", mas como um discurso engendrado em um processo enunciativo específico, que imprime marcas ao "texto" resultante. Nesse sentido, deslocamos o foco de investigação da "literatura dramática" para a prática coletiva de encenação. A essa escrita cênica - trabalho de tessitura de ações, uma vez que, como salienta Barba, "as ações só são operantes quando estão entrelaçadas, quando se tornam textura..." - nomearemos de dramaturgia em processo, porque “a palavra 'texto', antes de se referir a um texto escrito ou falado, impresso ou manuscrito, significa 'tecendo junto'...” 66.

O outro aspecto, profundamente ligado a esse, diz respeito à ação dramática. Deslocando o conceito de texto para a cena, deslocamos também a ação para o plano concreto. Desse modo, dilatamos o conceito aristotélico de ação dramática, que passa a ter sua relação ampliada para além do nível da personagem, englobando os diversos níveis da encenação: "todas as relações, todas as interações entre as personagens ou entre as personagens e as luzes, os sons e os espaços, são ações. Tudo o que trabalha diretamente com a atenção do espectador em sua compreensão, suas emoções, sua cinestesia, é uma ação" ${ }^{67}$

E, finalmente, a última premissa de nossa investigação diz respeito a um determinado modo de articulação coletiva dos elementos cênicos, o qual pressupõe um "pensar o fazer" absolutamente socializado, uma produção de sentido compartilhada por todos os criadores. Tal modo de articulação, eixo central do presente estudo, é o processo de criação colaborativa, "metodologia de criação em que todos os integrantes, a partir de suas funções artísticas específicas, têm igual espaço propositivo, sem qualquer espécie de hierarquias, produzindo uma obra cuja autoria é compartilhada por todos"

No bojo dessa investigação, estão presentes mais dois elementos, os quais consideramos intrinsecamente relacionados a essa forma de criação: o conceito de polifonia e o mecanismo épico-dramático. Uma vez que, no processo colaborativo, o texto não representa mais a voz de um autor ${ }^{69}$, mas é engendrado no embate das diversas vozes envolvidas na criação, podemos, para usar o conceito caro a Bakhtin, pensá-lo como um sistema polifônico ${ }^{70}$.

\footnotetext{
${ }^{66}$ BARBA \& SAVARESE: Dicionário de Antropologia Teatral.São Paulo: Hucitec, 1992.

${ }^{67}$ Idem.

${ }^{68}$ ARAUJO, A.: A gênese da vertigem: o processo de criação de O Paraíso Perdido. Dissertação de Mestrado (ECA/USP).

${ }^{69}$ Segundo Pavis, a encenação não representa mais a palavra de um autor (seja este autor dramático, encenador ou ator), porém a marca mais ou menos visível e assumida da palavra coletiva (o que Brecht denomina como "socialização do saber").

${ }^{70}$ ABREU, Luís A.: Processo colaborativo: relato e reflexões sobre uma experiência de criação. S/R.
} 
E tal sistema, tal embate no "corpo-a-corpo da sala de ensaio"71, não imprimiria determinadas soluções formais ao texto resultante? Tal questão é basilar e fundamenta a hipótese principal do presente estudo: é possível perceber como se articula a linguagem artística quando fruto de um pensamento coletivo, de uma visão artística compartilhada? E mais: como é possível imprimir, em nível ficcional, as marcas desses acordo precário, tenso, entre as vozes, no texto produzido nessa relação, tornar visível as marcas das diversas "vozes" presentes em um texto produzido em processo colaborativo?

Propomos então, investigar, através dos mecanismos épico-dramáticos, a articulação polifônica na trama dramatúrgica, na superfície do texto. Segundo se faz notar por uma grande parte dos estudos voltados à questão da narrativa ${ }^{72}$, a presença do elemento narrativo como desarticulador do cânone tradicional do texto teatral (de base dialético-dialógica) tem encontrado expressão tanto nas encenações como nos textos teatrais contemporâneos. $\mathrm{O}$ tecido dramatúrgico deixa de ser fiado na construção das personagens e passa a ser "tramado" por personas enunciadoras do discurso, ou seja, por sujeitos representativos do corpo social. Esse traço aproxima a experiência dos criadores da matéria criada, talvez por isso seja mesmo uma marca da dramaturgia contemporânea ${ }^{73}$.

Buscando a confluência dos aspectos apresentados na pesquisa, foi feito um recorte temático com enfoque na condição marginal da mulher (loucas, velhas, prostitutas), o qual, englobando os pressupostos teóricos de Foucault, mas também de Debord, Benjamin e Brecht, problematiza a relação entre indivíduo e sociedade. Tal recorte permite que a experimentação cênica, de base narrativa (embora com confluências dramáticas e líricas), amplie seu referencial textual, o qual abarcará do texto filosófico ou científico ao relato pessoal, memórias e escritos na parede. Além disso, o projeto propõe um enfoque mais preciso da pesquisa de procedimentos épicos-dramáticos ao concentrá-los nos estudos de Nara Keisermann sobre o ator rapsodo e na investigação do modelo de ações proposto por Artur Barrio. Por fim, a partir do conceito de interrupção proposto por Lehmann (em "Le théâtre post dramatique"), serão investigados os possíveis confrontos entre o real e o ficcional através da contaminação da relação cena/espectador por uma hiper-realidade e as possíveis redes de colaboração criativas advindas dessa relação.

Em relação à narrativa épico-dramática, podemos dizer que, segundo se faz notar por uma grande parte dos estudos voltados à questão (como exemplo, basta apontar aqueles

\footnotetext{
${ }^{71}$ ARAÚJO, A.: Op. Cit., p. 157.

${ }^{72}$ Pavis, Szondi, Ryngaert, Luiz Alberto de Abreu, Sílvia Fernandes, Luiz Arthur Nunes, dentre outros. Ver o número 9 da Percevejo, Revista da Pós-Graduação em Teatro da Unirio, que trata das relações entre narrativa e teatro.

${ }^{73}$ RYNGAERT, J.P.: Ler o teatro contemporâneo. São Paulo: Martins Fontes, 1997.
} 
realizados por Pavis, Szondi, Ryngaert, Luiz Alberto de Abreu, Sílvia Fernandes, Luiz Arthur Nunes, dentre outros), a presença do elemento narrativo como desarticulador do cânone tradicional do texto teatral (de base dialético-dialógica) tem encontrado expressão tanto nas encenações como nos textos teatrais contemporâneos. O tecido dramatúrgico deixa de ser fiado na construção das personagens e passa a ser "tramado" por personas enunciadoras do discurso, ou seja, por sujeitos representativos do corpo social. É nesse sentido que o material documental é pensado como fio condutor para a cena, uma vez que as "texturas" teatrais serão construídas do entrelaçamento dessas matérias. Esse traço aproxima a experiência dos criadores da matéria criada, talvez por isso seja mesmo uma marca da cena contemporânea.

\section{Metodologia}

A metodologia adotada estabelece uma divisão de três etapas para a pesquisa.

Primeira Etapa: caracterizada pela fundamentação teórica e prática da pesquisa, essa fase se divide em dois momentos:

a) Estudos de fundamentação. Os estudos concentram-se em duas áreas e serão desenvolvidos, simultaneamente, à pesquisa de campo.

ÁREA 1: Teorias da Memória. Leitura das principais textos teóricos, a fim de possibilitar o entendimento das narrativas colhidas junto aos atores sociais: as mulheres marginais.

ÁREA 2: Teorias teatrais. Leitura dos principais textos sobre dramaturgia processual e processos coletivos (além de textos teóricos da dramaturgia clássica e da encenação), a fim de permitir a identificação das mecanismos artísticos empregados para alavancar a criação artística.

b) Pesquisa de campo. Simultaneamente aos estudos teóricos, realizar-se-á, a coleta das lembranças e "causos" das mulheres, assim como a observação dos próprios atores sociais, essa fundamental para o trabalho posterior de criação de ações.

Segunda Etapa: consiste no desenvolvimento da pesquisa prática das linguagens teatrais, ou seja, a partir do material levantado na pesquisa de campo, os pesquisadores, através de 
laboratórios práticos de improvisação e de ensaios, vão elaborar o material plástico e verbal da encenação, o qual será organizado em termos dramatúrgicos e cênicos. Tanto as memórias quanto a observação dos idosos será matéria prima para o trabalho de improvisação de ações físicas e de textos verbais, os quais se pautarão na utilização de mecanismos de narrativa épicodramáticas pelos pesquisadores.

Terceira Etapa: caracterizada pela síntese, essa fase consiste na análise dos dados levantados nas etapas anteriores e da elaboração do texto final da pesquisa, concentrando todos os aspectos vistos até então. $\mathrm{O}$ texto final contemplará os seguintes tópicos:

1) Fundamentos teóricos.

2) Texto teatral produzido.

3) Descrição do processo de criação;

4) Análise dos mecanismos teatrais empregados no processo de criação artística;

5) Ensaio sobre dramaturgia e encenação colaborativa.

\begin{tabular}{|c|c|c|c|c|c|c|c|c|c|c|c|c|}
\hline \multicolumn{13}{|c|}{ - CRONOGRAMA DE EXECUÇÃO DAS ETAPAS DO PROJETO } \\
\hline \multicolumn{13}{|c|}{ MESES } \\
\hline Atividades (etapas) & $\mathbf{0 1}$ & $\mathbf{0 2}$ & 03 & $\mathbf{0 4}$ & 05 & 06 & o7 & $\mathbf{0 8}$ & 09 & 10 & $\mathbf{1 1}$ & 12 \\
\hline Estudos de Fundamentação teórica & $\mathrm{x}$ & $\mathrm{x}$ & & & $\mathrm{x}$ & & $\mathrm{x}$ & & & & & \\
\hline Estudo prático: procedimentos & & $\mathrm{x}$ & $\mathrm{x}$ & & $\mathrm{x}$ & $\mathrm{x}$ & $\mathrm{x}$ & $\mathrm{x}$ & $\mathrm{x}$ & & & \\
\hline Pesquisa de campo & & $\mathrm{x}$ & $\mathrm{x}$ & & $\mathrm{x}$ & $\mathrm{x}$ & $\mathrm{x}$ & & & & & \\
\hline Pesquisa de outros materiais & $\mathrm{x}$ & $\mathrm{x}$ & & & $\mathrm{x}$ & $\mathrm{x}$ & $\mathrm{x}$ & $\mathrm{x}$ & & & & \\
\hline \begin{tabular}{|lll} 
Experimentos com material & com
\end{tabular} & & $\mathrm{x}$ & $\mathrm{x}$ & $\mathrm{x}$ & $\mathrm{x}$ & $\mathrm{x}$ & $\mathrm{x}$ & $\mathrm{x}$ & $\mathrm{x}$ & & & \\
\hline Mostras Processuais com debates & & & $\mathrm{x}$ & & $\mathrm{x}$ & & $\mathrm{x}$ & & & $\mathrm{x}$ & & \\
\hline Avaliação $\quad$ resultados: $\quad$ novas & & & & $\mathrm{x}$ & & $\mathrm{x}$ & & $\mathrm{x}$ & $\mathrm{x}$ & & & \\
\hline Elaboração de relatos/diários de & $\mathrm{x}$ & $\mathrm{x}$ & $\mathrm{x}$ & $\mathrm{x}$ & $\mathrm{x}$ & $\mathrm{x}$ & $\mathrm{x}$ & $\mathrm{x}$ & $\mathrm{x}$ & $\mathrm{x}$ & & \\
\hline \begin{tabular}{|lll} 
Registro áudio-visual & dos
\end{tabular} & & $\mathrm{x}$ & $\mathrm{x}$ & $\mathrm{x}$ & $\mathrm{x}$ & $\mathrm{x}$ & $\mathrm{x}$ & $\mathrm{x}$ & $\mathrm{x}$ & $\mathrm{x}$ & & \\
\hline Organização dos dados e registros & & & & $\mathrm{x}$ & & $\mathrm{x}$ & & $\mathrm{x}$ & & $\mathrm{x}$ & & \\
\hline Produção de material bibliográfico & & & & & & $\mathrm{x}$ & & & & $\mathrm{x}$ & $\mathrm{x}$ & \\
\hline Relatório final & & & & & & & & & & & & $\mathrm{x}$ \\
\hline
\end{tabular}




\section{Referências Bibliográficas}

ARAÚJO, Antônio C. A Gênese da Vertigem: O Processo de Criação de O Paraíso Perdido. São Paulo: 2002 (Dissertação de Mestrado - ECA - USP).

ARTAUD, Antonin: O teatro e seu duplo. São Paulo: Max Limonad, 1987.

: Linguagem e vida. São Paulo: Perspectiva, 2004.

BACHELARD, Gaston. A poética do espaço. São Paulo: Martins Fontes, 2002.

BAKHTIN, Mikhail. Problemas da poética de Dostoiévski. Rio de Janeiro: Forense Universitária, 1987.

BARBA, Eugênio e SAVARESE, Nicola. A arte secreta do ator: dicionário de antropologia teatral.

São Paulo, Campinas: Hucitec, 1995.

BARRIGA, Merle Ivone. As ações de Artur Barrio...

BORNHEIM, Gerd: Brecht: a estética do teatro. Rio de Janeiro: Graal, 1992.

CANEVACCI, Massimo. A Cidade Polifônica. São Paulo: Livros Studio Nobel Ltda., 1997

CERTEAU, Michel de. A Invenção do cotidiano: artes de fazer. Petrópolis: Vozes, 1994.

COHEN, Renato. Performance como linguagem. São Paulo: Perspectiva, 2004a.

Work in progress na cena contemporânea: criação, encenação e recepção. São

Paulo: Perspectiva, 2004b.

DELEUZE, Gilles, GUATTARI, Félix. Mil Platôs - Capitalismo e Esquizofrenia. São Paulo:

Editora 34, 1995.

DERRIDA, Jacques. A escritura e a diferença. São Paulo: Perspectiva, 2005.

DUCROT, Osvald. Esboço de uma teoria polifônica da enunciação. In: O dizer e o dito.

Campinas: Pontes Editores, 1987.

ECO, Umberto: Obra Aberta. São Paulo: Editora Perspectiva, 1991.

FERRACINI, Renato. A arte de não interpretar como poesia corpórea do ator. Campinas. Editora da UNICAMP, 2001.

FOUCAULT, Michel. História da Loucura. São Paulo: Editora Perspectiva,

O que é um autor? IN: Ditos e Escritos, III. Rio de Janeiro: Forense

Universitária, 2006.

GUATTARI, Felix. Caosmose: um novo paradigma estético. São Paulo: Editora 34, 1992.

KEISERMANN, Nara: O ator rapsodo.

LEHMANN, Hans-Thies: Le théâtre postdramatique. Paris: L'Arche, 2002.

O PERCEVEJO. Revista do Programa de Pós-Graduação em Teatro da Unirio. Rio de Janeiro:

Editora da Unirio. Número 9, 1998.

REWALD, Rubens A. Caos/Dramaturgia. São Paulo: Perspectiva, 2005.

ROSENFELD, Anatol. O teatro épico. Coleção Estudos. São Paulo: Perspectiva, 1990. 
RYNGAERT, Jean-Pierre: Ler o teatro contemporâneo. São Paulo: Martins Fontes, 1998. SANTOS, Milton. A Natureza do Espaço. São Paulo, Editora EDUSP, 2002. UBERSFELD, Anne. Lire lê théâtre II : l'école du spectateur. Paris : Belin, 1996. 